\title{
Patching EAF-2010 into CINDER2008 Cross Section Libraries
}

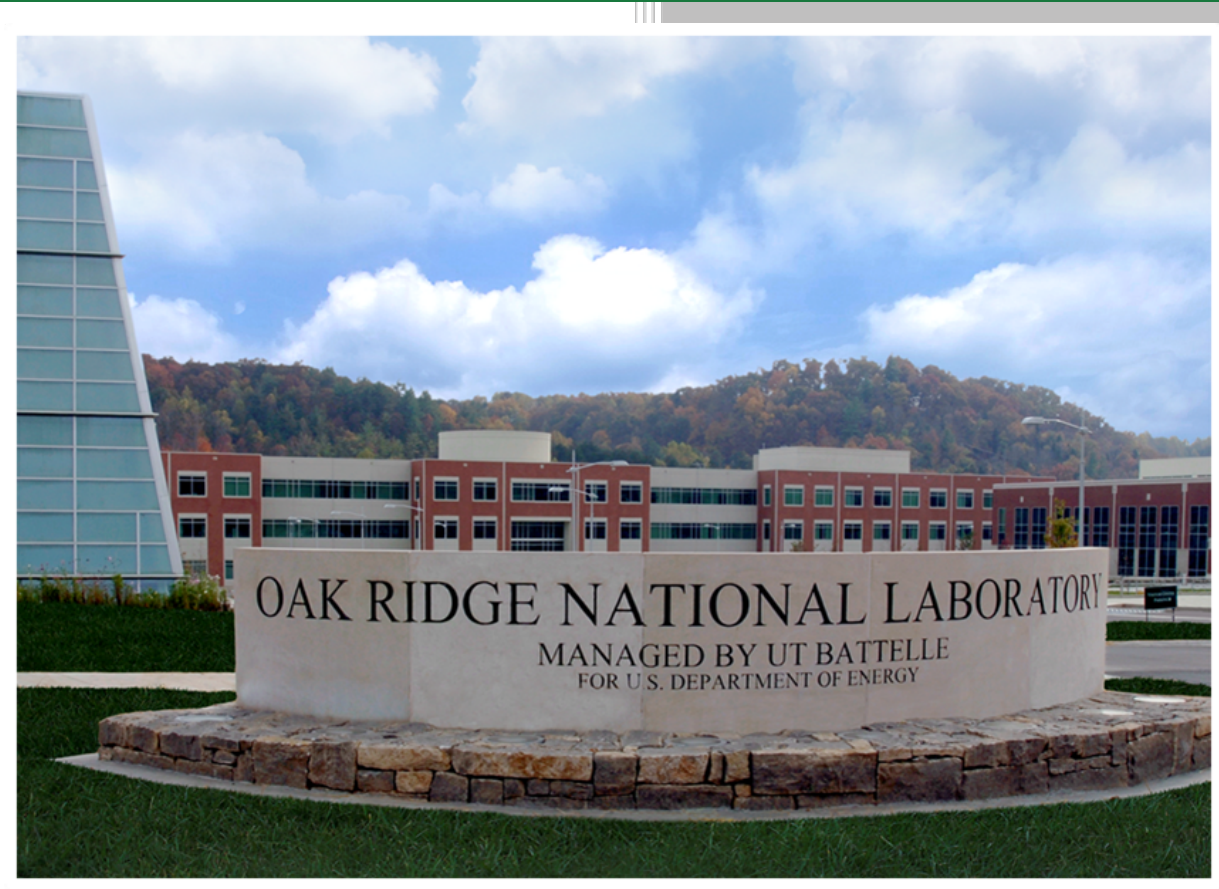

Approved for public release.

Distribution is unlimited.

Wei Lu

Franz X. Gallmeier

September, 2016 


\section{DOCUMENT AVAILABILITY}

Reports produced after January 1, 1996, are generally available free via US Department of Energy (DOE) SciTech Connect.

Website http://www.osti.gov/scitech/

Reports produced before January 1, 1996, may be purchased by members of the public from the following source:

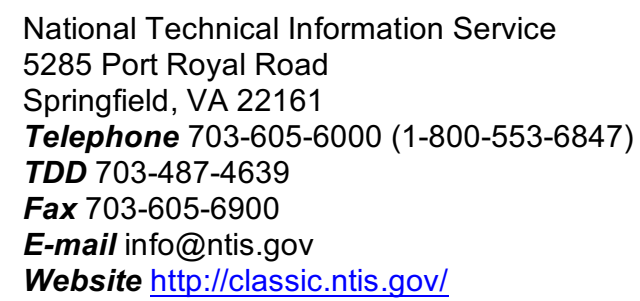

Reports are available to DOE employees, DOE contractors, Energy Technology Data Exchange representatives, and International Nuclear Information System representatives from the following source:

Office of Scientific and Technical Information

PO Box 62

Oak Ridge, TN 37831

Telephone 865-576-8401

Fax 865-576-5728

E-mail reports@osti.gov

Website http://www.osti.gov/contact.html

This report was prepared as an account of work sponsored by an agency of the United States Government. Neither the United States Government nor any agency thereof, nor any of their employees, makes any warranty, express or implied, or assumes any legal liability or responsibility for the accuracy, completeness, or usefulness of any information, apparatus, product, or process disclosed, or represents that its use would not infringe privately owned rights. Reference herein to any specific commercial product, process, or service by trade name, trademark, manufacturer, or otherwise, does not necessarily constitute or imply its endorsement, recommendation, or favoring by the United States Government or any agency thereof. The views and opinions of authors expressed herein do not necessarily state or reflect those of the United States Government or any agency thereof. 
Neutron Technologies Division

\title{
Patching EAF-2010 into CINDER2008 Cross Section Libraries
}

\author{
Wei Lu and Franz X. Gallmeier
}

Date Published: September, 2016

\author{
Prepared by \\ OAK RIDGE NATIONAL LABORATORY \\ Oak Ridge, TN 37831-6283 \\ managed by \\ UT-BATTELLE, LLC \\ for the \\ US DEPARTMENT OF ENERGY \\ under contract DE-AC05-00OR22725
}





\section{CONTENTS}

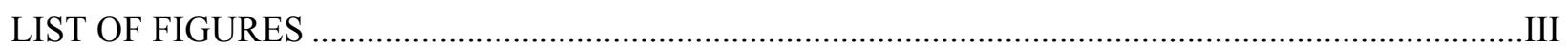

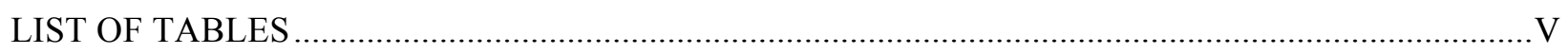

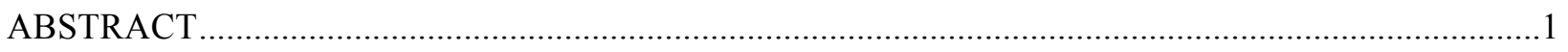

1. CINDER2008 CROSS SECTION LIBRARIES AND THEIR PROBLEM .......................................

2. METHOD OF REPATCHING EAF-2010 INTO CINDER2008 CROSS SECTION LIBS. ...............4

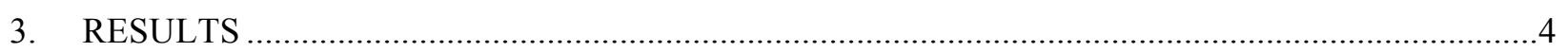

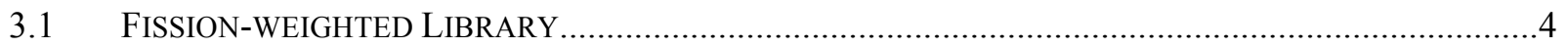

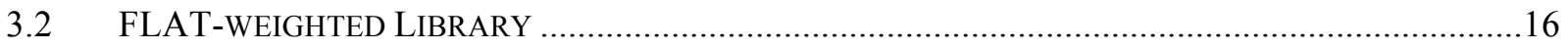

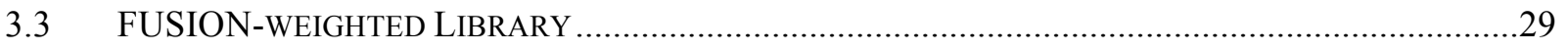

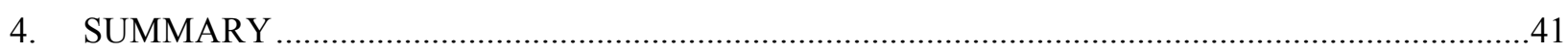

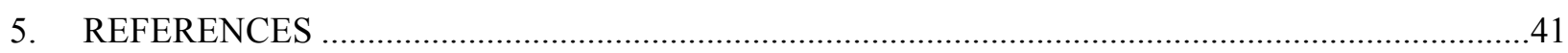

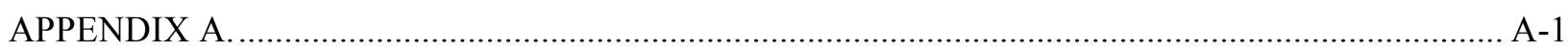

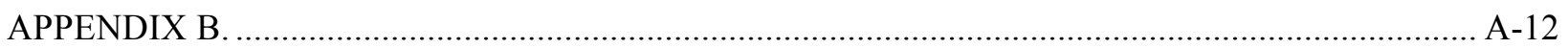




\section{LIST OF FIGURES}

Figure 1. (n, G) reaction cross section for O18 in the current CINDER2008 cross section libraries, where the fusion and flat spectra are truncated around 0.6 and $10 \mathrm{MeV}$, respectively.

Figure 2. Four reaction cross sections in EAF-2010 (as of July 22, 2016) with their threshold energy higher than the upper limit energy bin of the group structure in the updated CINDER2008 fission-weighted library. .............6

Figure 3. Production cross sections of $\mathrm{Pb} 203$ and its isomers through $(\mathrm{n}, \mathrm{G})$ reaction in the current and updated

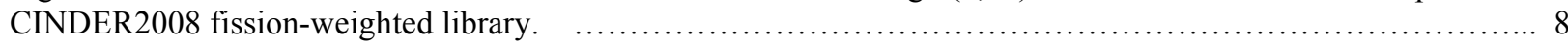

Figure 4. Two examples of reaction cross sections appearing in the updated CINDER2008 fission-weighted library but not present in the current CINDER2008 fission-weighted library.

Figure 5. Examples of reaction cross sections showing significant differences between the current and updated CINDER2008 fission-weighted library, but that are not of serious concern.

Figure 6. Six reaction cross sections showing significant difference between the current and updated CINDER2008 fission-weighted library which are of serious concern.

Figure 7. Reaction cross sections shown in the current CINDER2008 flat-weighted library but not in the updated one due to the cut-off treatment of the CINDER2008 library maker tool.

Figure 8. Examples of reaction cross sections wrongly missing in the current CINDER2008 flat-weighted library but present in updated CINDER2008 flat-weighted library.

Figure 9. Three reactions with insignificant cross sections not in the current CINDER2008 flat-weighted library but present in the updated CINDER2008 flat-weighted library.

Figure 10. Examples of reaction cross sections truncated below $10 \mathrm{MeV}$ in the current CINDER2008 flat-weighted

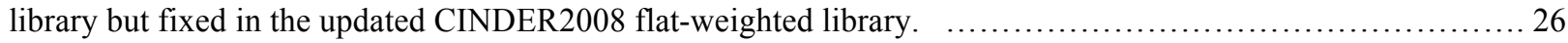

Figure 11. Reaction cross sections with significant difference between the current and updated CINDER2008 flatweighted libraries, which my require further examination. 28 Figure 12. Examples of reaction cross sections presentin the current CINDER2008 fusion-weighted library but not in the updated CINDER2008 fusion-weighted library. 31 Figure 13. Reaction cross sections missed in the current CINDER2008 fusion-weighted library but fixed in the updated fusion-weighted library.

Figure 14. Reaction cross sections with insignificant values not in the current CINDER2008 fusion-weighted library but present in the updated CINDER2008 fusion-weighted library.

Figure 15. Examples of reaction cross sections truncated below $\sim 0.6 \mathrm{MeV}$ in the current CINDER2008 fusionweighted library but fixed in the updated CINDER2008 fusion-weighted library (lowest energy bin stops at 1E-8 $\mathrm{MeV}$ to illustrate the lowest energy group $1 \mathrm{E}-11-1 \mathrm{E}-7 \mathrm{MeV})$.

Figure 16. Reaction cross sections with significant difference between the current CINDER2008 fusion-weighted library and the updated one, which may require further examination. 


\section{LIST OF TABLES}

Table 1. Distribution of the evaluated cross section data sources in CINDER2008 libraries.

Table 2. List of 386 nuclides in CINDER2008 libraries with reaction cross sections from EAF-2010 (m1 and m2 stands for $1^{\text {st }}$ and $2^{\text {nd }}$ metastable state, respectively).

Table 3. List of 37 reaction cross sections in the current CINDER2008 fission-weighted library but not in the updated CINDER2008 fission-weighted library.

Table 4. List of fourteen reaction cross sections not present in the current CINDER2008 fission-weighted library but present in the updated CINDER2008 fission-weighted library.

Table 5. List of six reaction cross sections with significant difference between the current and updated

CINDER2008 fission libraries which are of serious concern.

Table 6. List of 37 reaction cross sections in the current CINDER2008 flat-weighted library but not in the updated CINDER2008 flat-weighted library.

Table 7. List of 167 reaction cross sections missing in the current CINDER2008 flat-weighted library but present in the updated CINDER2008 flat-weighted library.

Table 8. List of 101 reaction cross sections in the current CINDER2008 fusion-weighted library but not in the updated CINDER2008 fusion-weighted library. 


\begin{abstract}
CINDER2008 [1] comes with multi-group cross section libraries using most recent evaluated cross section data. The multi-group cross sections are weighted with three spectra: fission, fusion and flat. However, due to data format incompatibilities with the CINDER2008 library maker tool, many of the reaction cross sections adapted from EAF-2010 [2] are either truncated or completely missing. Therefore it is essential to regenerate the CINDER2008 libraries with compatible EAF-2010 data. The updated cross section libraries are compared to those of the current cross section libraries in the sections below following a brief introduction of the CINDER2008 cross section libraries and a description of the method of generating cross sections for the CINDER2008 code. In the remainder of this document, we will refer to the libraries distributed with CINDER2008 before October 2016 as the "current" libraries, and those described in this work as the "updated" libraries. In figures, the current library data may be shown with the library name with or without "cur" appended, while the updated library data may be shown with "mod" appended.
\end{abstract}

\title{
1. CINDER2008 CROSS SECTION LIBRARIES AND THEIR PROBLEM
}

The cross section libraries distributed with CINDER2008 are significantly changed from those distributed with its previous version, CINDER'90 [3]. Most of the cross sections are updated with most recent evaluated cross section data from ENDF VII [4], EAF-2010 and JENDL 4.0 and 3.1 [5]. The total number of nuclides included has gone from 3400 in CINDER'90 to 4084 in CINDER2008. The cross section libraries include reaction cross sections, decay gamma spectra, decay ratios, fission cross sections, fission product yield and hazardous material categories. However, in this report only the reaction cross sections are discussed. The multi-group reaction cross sections in CINDER2008 are provided in three separate libraries, as weighted by different neutron spectra (fission, fusion, and flat), in order to make calculations more accurate in different radiation environments. Both the fission and flat cross section libraries cover the same energy range (1E-11 - 25 MeV), but the flat library has a much more refined energy bin structure: 321 groups rather than 66. The fission library group structure for CINDER2008 is changed from the CINDER'90 library only by subdividing the lowest-energy CINDER'90 group (1E-11 $5 \mathrm{E}-9 \mathrm{MeV}$ ) into four groups covering the same energy range. Although the fusion library covers seemingly the similar energy range (1E-11 - $19.64 \mathrm{MeV})$ with 175 energy groups, its lowest energy group spans 4 orders of magnitude (1E-11 - $1 \mathrm{E}-7 \mathrm{MeV})$.

Among the 4084 nuclides in the CINDER2008 libraries, the majority of them, 3265 nuclides, have no reaction cross sections, only decay information, etc. The remaining 819 nuclides have reaction cross sections from EAF-2010, ENDF-VII, and JENDL (both 4.0 and 3.1). The distribution of the evaluated cross section data source for the reaction cross section is listed in Table 1, where "mixed libs" means the reaction cross sections for a certain nuclide come from some combination of ENDF VII, JENDL 4.0 and 3.1. However, none of the nuclides adopting the EAF-2010 cross section uses other evaluated data source. 
Table 1. Distribution of the evaluated cross section data sources in CINDER2008 libraries.

\begin{tabular}{|c|c|}
\hline C.S. library & Nuclide number \\
\hline None & 3265 \\
\hline EAF-2010 & 386 \\
\hline ENDF VII & 162 \\
\hline JENDL 4.0 & 138 \\
\hline Mixed libs & 113 \\
\hline JENDL 3.1 & 20 \\
\hline
\end{tabular}

Although EAF-2010 is the largest contributor to the nuclides whose reaction cross sections are not found either in ENDF VII or JENDL, it is found that in the current CINDER2008 cross section libraries many of the reaction cross sections are truncated in the fusion and flat libraries. Fig. 1 shows such an example for the $(n, G)$ reaction of O18. The fusion cross sections in Fig. 1 are truncated around $0.6 \mathrm{MeV}$ while the flat ones are truncated around $10 \mathrm{MeV}$. This may be due to the fact that the cross section data format of EAF-2010 used for importing into the CINDER2008 code was not compatible with the library maker tool of the code. Regardless, this leaves a serious impact on the accuracy of the CINDER2008 cross section libraries. The reaction cross sections for all 386 nuclides coming from EAF-2010 must therefore be regenerated. Table 2 shows the full list of the 386 nuclides in the CINDER2008 libraries coming from EAF-2010.

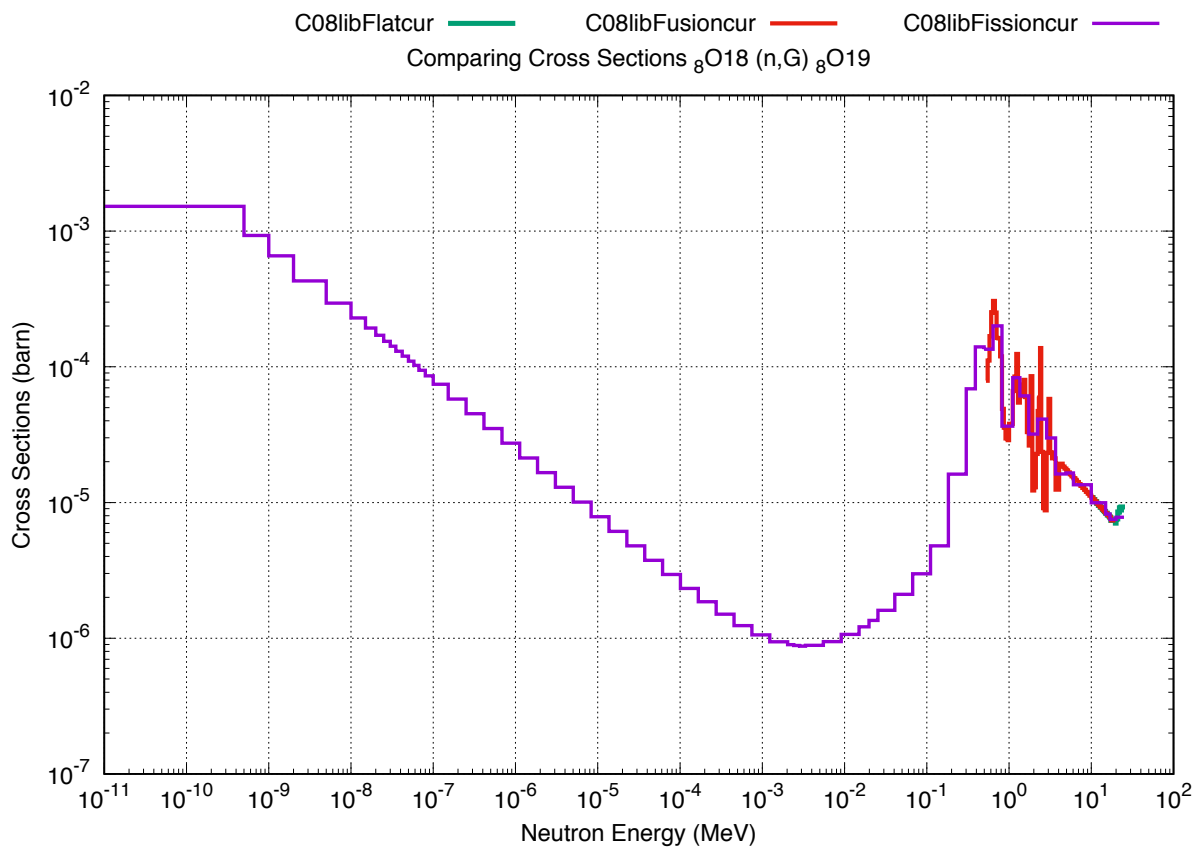

Figure 1. (n, G) reaction cross section for O18 in the current CINDER2008 cross section libraries, where the fusion and flat spectra are truncated around 0.6 and $10 \mathrm{MeV}$, respectively.

Table 2. List of 386 nuclides in CINDER2008 libraries with reaction cross sections from EAF-2010 ( $\mathrm{m} 1$ and m2 stands for $1^{\text {st }}$ and $2^{\text {nd }}$ metastable state, respectively).

\begin{tabular}{|c|c|c|c|c|c|c|c|c|c|}
\hline Be7 & Be10 & C12 & C13 & C14 & O18 & Ne20 & Ne21 & Ne22 & Na24 \\
\hline Mg28 & A126 & Si31 & Si32 & P32 & P33 & S35 & C136 & Ar37 & Ar39 \\
\hline
\end{tabular}




\begin{tabular}{|c|c|c|c|c|c|c|c|c|c|}
\hline Ar41 & Ar42 & K42 & K43 & $\mathrm{Ca} 41$ & $\mathrm{Ca} 45$ & $\mathrm{Ca} 47$ & Sc44m1 & Sc46 & Sc47 \\
\hline $\mathrm{Sc} 48$ & Ti44 & Ti45 & V48 & V49 & $\mathrm{Cr} 48$ & $\mathrm{Cr} 51$ & Mn52 & Mn53 & Mn54 \\
\hline $\mathrm{Fe} 52$ & $\mathrm{Fe} 55$ & Fe60 & Co55 & Co56 & Co57 & Co60 & Ni56 & $\mathrm{Ni57}$ & Ni63 \\
\hline Ni66 & $\mathrm{Cu} 64$ & $\mathrm{Cu} 67$ & Zn62 & Zn69m1 & Zn72 & Ga66 & Ga67 & Ga72 & Ge68 \\
\hline Ge69 & Ge71 & Ge77 & As71 & As72 & As73 & As76 & As77 & $\mathrm{Se} 72$ & $\mathrm{Se} 73$ \\
\hline $\mathrm{Se} 75$ & $\mathrm{Br} 76$ & Br77 & Br82 & $\mathrm{Kr} 76$ & Kr79 & Kr81 & $\mathrm{Rb} 82 \mathrm{~m} 1$ & $\mathrm{Rb} 83$ & $\mathrm{Rb} 84$ \\
\hline Sr82 & Sr83 & Sr85 & $\operatorname{Sr} 91$ & Y86 & Y87 & Y87m1 & Y88 & Y93 & Zr86 \\
\hline $\mathrm{Zr} 88$ & Zr89 & Zr97 & $\mathrm{Nb} 90$ & Nb91 & $\mathrm{Nb91m1}$ & $\mathrm{Nb92}$ & $\mathrm{Nb92m1}$ & $\mathrm{Nb93m1}$ & $\mathrm{Nb95m1}$ \\
\hline $\mathrm{Nb96}$ & Mo93 & Mo93m1 & Tc95 & Tc95m1 & Тc96 & Tc97 & Tc97m1 & Тc98 & Tc99m1 \\
\hline Ru97 & Rh99 & Rh99m1 & Rh100 & Rh101 & $\mathrm{Rh} 101 \mathrm{~m} 1$ & Rh102 & Rh102m1 & $\operatorname{Pd} 100$ & $\operatorname{Pd} 101$ \\
\hline Pd103 & Pd109 & $\operatorname{Pd} 112$ & Ag105 & $\operatorname{Ag} 106 \mathrm{~m} 1$ & Ag108m1 & $\mathrm{Cd} 107$ & Cd109 & $\mathrm{Cd} 113 \mathrm{~m} 1$ & $\mathrm{Cd} 115$ \\
\hline In111 & In $114 \mathrm{~m} 1$ & $\mathrm{Sn} 117 \mathrm{~m} 1$ & $\mathrm{Sn} 119 \mathrm{~m} 1$ & Sn121 & $\mathrm{Sn} 121 \mathrm{~m} 1$ & Sb119 & Sb120m1 & $\mathrm{Sb} 122$ & $\mathrm{Sb} 127$ \\
\hline Sb128 & Te118 & Te119 & Te119m1 & Te121 & $\mathrm{Te} 121 \mathrm{~m} 1$ & $\mathrm{Te} 123 \mathrm{~m} 1$ & $\mathrm{Te} 125 \mathrm{~m} 1$ & Te127 & Te129 \\
\hline $\mathrm{Te} 131 \mathrm{~m} 1$ & I123 & I124 & I125 & I126 & I128 & I133 & Xe122 & Xe125 & Xe127 \\
\hline $\mathrm{Xe} 129 \mathrm{~m} 1$ & $\mathrm{Xe} 131 \mathrm{~m} 1$ & $\mathrm{Xe} 133 \mathrm{~m} 1$ & Cs 127 & Cs129 & Cs131 & Cs132 & $\mathrm{Ba} 128$ & Ba129 & Ba131 \\
\hline $\mathrm{Ba} 133 \mathrm{~m} 1$ & $\mathrm{Ba} 135 \mathrm{~m} 1$ & Ba139 & La135 & La137 & La141 & Ce134 & Ce135 & Ce137 & $\mathrm{Ce} 137 \mathrm{~m} 1$ \\
\hline $\mathrm{Nd} 140$ & $\mathrm{Nd} 141$ & $\mathrm{Nd} 149$ & Pm143 & Pm144 & Pm145 & Pm146 & Pm150 & Sm145 & Sm146 \\
\hline Sm156 & Eu145 & Eu146 & Eu147 & Eu148 & Eu149 & Eu150 & Eu150m1 & Eu152m1 & Gd146 \\
\hline Gd147 & Gd148 & Gd149 & Gd150 & Gd151 & Gd159 & Tb151 & Tb152 & Tb153 & Tb154 \\
\hline $\mathrm{Tb} 154 \mathrm{~m} 1$ & $\mathrm{~Tb} 154 \mathrm{~m} 2$ & Tb155 & Tb156 & Tb156m1 & $\mathrm{Tb} 156 \mathrm{~m} 2$ & Tb157 & Tb158 & Tb161 & Dy153 \\
\hline Dy155 & Dy157 & Dy165 & Dy166 & Ho163 & Ho164 & Ho164m1 & Ho166 & Ho166m1 & Er160 \\
\hline Er161 & Er165 & Er169 & Er171 & Er172 & $\operatorname{Tm} 165$ & $\operatorname{Tm} 166$ & $\operatorname{Tm} 167$ & $\operatorname{Tm} 168$ & $\operatorname{Tm} 170$ \\
\hline $\operatorname{Tm} 171$ & $\operatorname{Tm} 172$ & $\operatorname{Tm} 173$ & Yb166 & Yb169 & Yb175 & Lu169 & Lu170 & Lu171 & Lu172 \\
\hline Lu173 & Lu174 & Lu174m1 & Lu177 & Lu177m1 & Hf170 & Hf171 & Hf172 & Hf173 & Hf175 \\
\hline $\mathrm{Hf} 178 \mathrm{~m} 2$ & Hf179m2 & Hf180m 1 & Ta175 & Ta176 & Ta177 & Ta179 & Ta180 & Ta180m1 & Ta183 \\
\hline Ta184 & W178 & W181 & W185 & W187 & W188 & $\operatorname{Re} 181$ & Re182 & $\operatorname{Re} 182 \mathrm{~m} 1$ & $\operatorname{Re} 183$ \\
\hline $\operatorname{Re} 184$ & $\operatorname{Re} 184 \mathrm{~m} 1$ & $\operatorname{Re} 186$ & $\operatorname{Re} 186 \mathrm{~m} 1$ & $\operatorname{Re} 188$ & Re189 & Os182 & Os183 & Os $183 \mathrm{~m} 1$ & Os185 \\
\hline Os191 & Os191m1 & Os193 & Os194 & Ir 185 & $\operatorname{Ir} 186$ & Ir187 & Ir188 & Ir189 & Ir190 \\
\hline Ir192 & $\operatorname{Ir} 192 \mathrm{~m} 2$ & Ir193m1 & Ir194 & Ir194m2 & Ir196m1 & Pt188 & Pt189 & Pt190 & Pt191 \\
\hline Pt192 & Pt193 & Pt193m1 & Pt194 & Pt195 & Pt195m1 & Pt196 & Pt197 & Pt198 & Pt200 \\
\hline Pt202 & Au193 & Au194 & Au195 & Au196 & $\mathrm{Au} 196 \mathrm{~m} 2$ & Au198 & Au198m1 & Au199 & $\mathrm{Au} 200 \mathrm{~m} 1$ \\
\hline $\mathrm{Hg} 193$ & Hg193m1 & Hg 194 & Hg 195 & $\mathrm{Hg} 195 \mathrm{~m} 1$ & Hg197 & $\mathrm{Hg} 197 \mathrm{~m} 1$ & Hg203 & $\mathrm{T} 1199$ & $\mathrm{~T} 1200$ \\
\hline $\mathrm{T} 1201$ & $\mathrm{~T} 1202$ & $\mathrm{~T} 1203$ & $\mathrm{~T} 1204$ & $\mathrm{~T} 1205$ & $\mathrm{~Pb} 200$ & $\mathrm{~Pb} 201$ & $\mathrm{~Pb} 202$ & $\mathrm{~Pb} 203$ & $\mathrm{~Pb} 205$ \\
\hline $\mathrm{Pb} 209$ & $\mathrm{~Pb} 210$ & $\mathrm{~Pb} 212$ & Bi203 & Bi204 & Bi205 & Bi206 & Bi207 & Bi208 & $\mathrm{Bi} 210$ \\
\hline Bi210m1 & Po206 & Po207 & Po208 & Po209 & Po210 & At 210 & At 211 & Rn211 & Rn222 \\
\hline $\mathrm{Ra} 228$ & Ac228 & $\mathrm{Pa} 228$ & $\mathrm{~Pa} 234$ & $\mathrm{~Np} 236 \mathrm{~m} 1$ & $\mathrm{Pu} 234$ & $\mathrm{Pu} 245$ & $\mathrm{Pu} 247$ & Am239 & $\mathrm{Bk} 248 \mathrm{~m} 1$ \\
\hline Es 250 & Es256m1 & Es257 & Fm 252 & Fm 253 & Fm257 & & & & \\
\hline
\end{tabular}




\section{METHOD OF REPATCHING EAF-2010 INTO CINDER2008 CROSS SECTION LIBS.}

The correct ENDF formatted EAF-2010 cross section data were downloaded from the t 2 website [6]. The point-wise cross section data were then converted into group-weighted cross sections using NJOY99 [711] according to the energy structures of the fission, fusion and flat spectra in CINDER2008 libraries. The main module of NJOY99 used for this conversion is GROUPR, while MODER, RECONR, BROADR and UNRESR were used for preparing the cross section data for the GROUPR module. The cross section libraries for CINDER2008 were finally generated with its included library maker tool.

\section{RESULTS}

\subsection{FISSION-WEIGHTED LIBRARY}

While the fission cross section library does not show obvious problems in the current CINDER2008 version, the updated version serves as a good reference point for checking the consistency of the EAF2010 data and the correctness of the cross section generating method. Comparisons of the current and updated CINDER2008 fission-weighted cross section libraries do, however, show some inconsistency, as discussed below.

There are 37 reaction cross sections, listed in Table 3, which are in the current CINDER2008 fissionweighted library but are missing in the updated CINDER2008 one. Among them there are 29 reactions marked (*) verified to not be present in EAF-2010. The four reactions marked ( $\dagger$ ) in Table 3 are present in EAF-2010 with cross sections in the current CINDER2008 fission-weighted library shown in Figure 2. However, the EAF-2010 libraries as of July 22, 2016 show reaction threshold energies above the upper energy limit $(25 \mathrm{MeV})$ of the fission group structure, and are thus not present in the updated CINDER2008 libraries.

Table 3. List of 37 reaction cross sections in the current CINDER2008 fission-weighted library but not in the updated CINDER2008 fission-weighted library.

\begin{tabular}{|l|l|l||l|l|l|}
\hline $\begin{array}{l}\text { Target } \\
\text { Nucl. }\end{array}$ & Reactions & $\begin{array}{l}\text { Product } \\
\text { Nucl. }\end{array}$ & Target Nucl. & Reactions & $\begin{array}{l}\text { Product } \\
\text { Nucl. }\end{array}$ \\
\hline$* 30 \mathrm{Zn} 62$ & $(\mathrm{n}, 2 \mathrm{~N})$ & $30 \mathrm{Zn} 61 \mathrm{~m} 1$ & $* 83 \mathrm{Bi} 203$ & $(\mathrm{n}, \mathrm{NA})$ & $81 \mathrm{~T} 1199 \mathrm{~m} 1$ \\
\hline$* 30 \mathrm{Zn} 62$ & $(\mathrm{n}, 2 \mathrm{~N})$ & $30 \mathrm{Zn} 61 \mathrm{~m} 2$ & $* 83 \mathrm{Bi} 203$ & $(\mathrm{n}, \mathrm{N} 3 \mathrm{HE}$ A PT) & $81 \mathrm{~T} 1200 \mathrm{~m} 1$ \\
\hline$* 30 \mathrm{Zn} 62$ & $(\mathrm{n}, 2 \mathrm{~N})$ & $30 \mathrm{Zn} 61 \mathrm{~m} 3$ & $* 83 \mathrm{Bi} 203$ & $\begin{array}{l}(\mathrm{n}, \mathrm{N} 2 \mathrm{P} 3 \mathrm{HE} \\
\text { PD }\end{array}$ & $81 \mathrm{~T} 1201 \mathrm{~m} 1$ \\
\hline$* 52 \mathrm{Te} 129$ & $(\mathrm{n}, 2 \mathrm{~N})$ & $52 \mathrm{Te} 128 \mathrm{~m} 1$ & $* 84 \mathrm{Po} 206$ & $(\mathrm{n}, \mathrm{TA})$ & $81 \mathrm{~T} 1200 \mathrm{~m} 1$ \\
\hline$* 56 \mathrm{Ba} 129$ & $(\mathrm{n}, \mathrm{ND} 2 \mathrm{NP} \mathrm{T})$ & $55 \mathrm{Cs} 127 \mathrm{~m} 1$ & $* 84 \mathrm{Po} 206$ & $(\mathrm{n}, \mathrm{NPA} \mathrm{DA})$ & $81 \mathrm{~T} 1201 \mathrm{~m} 1$ \\
\hline$* 56 \mathrm{Ba} 129$ & $(\mathrm{n}, \mathrm{G})$ & $56 \mathrm{Ba} 130 \mathrm{~m} 1$ & $* 84 \mathrm{Po} 206$ & $(\mathrm{n}, 2 \mathrm{~N})$ & $84 \mathrm{Po} 205 \mathrm{~m} 1$ \\
\hline$* 58 \mathrm{Ce} 134$ & $(\mathrm{n}, \mathrm{NA})$ & $56 \mathrm{Ba} 130 \mathrm{~m} 1$ & $* 84 \mathrm{Po} 206$ & $(\mathrm{n}, 2 \mathrm{~N})$ & $84 \mathrm{Po} 205 \mathrm{~m} 2$ \\
\hline$* 58 \mathrm{Ce} 134$ & $(\mathrm{n}, 3 \mathrm{~N})$ & $58 \mathrm{Ce} 132 \mathrm{~m} 1$ & $* 85 \mathrm{At} 211$ & $(\mathrm{n}, 2 \mathrm{~A})$ & $81 \mathrm{~T} 1204 \mathrm{~m} 1$ \\
\hline$* 58 \mathrm{Ce} 137$ & $(\mathrm{n}, 2 \mathrm{~N})$ & $58 \mathrm{Ce} 136 \mathrm{~m} 1$ & $* 85 \mathrm{At} 211$ & $(\mathrm{n}, 2 \mathrm{NA})$ & $83 \mathrm{Bi} 206 \mathrm{~m} 1$ \\
\hline$* 58 \mathrm{Ce} 137$ & $(\mathrm{n}, \mathrm{G})$ & $58 \mathrm{Ce} 138 \mathrm{~m} 1$ & $* 85 \mathrm{At} 211$ & $(\mathrm{n}, \mathrm{NA})$ & $83 \mathrm{Bi} 207 \mathrm{~m} 1$ \\
\hline$* 61 \mathrm{Pm} 143$ & $(\mathrm{n}, \mathrm{NPA}$ DA $)$ & $58 \mathrm{Ce} 138 \mathrm{~m} 1$ & $\dagger 28 \mathrm{Ni} 57$ & $(\mathrm{n}, 2 \mathrm{NA})$ & $26 \mathrm{Fe} 52 \mathrm{~m} 1$ \\
\hline$* 61 \mathrm{Pm} 143$ & $(\mathrm{n}, \mathrm{NT})$ & $60 \mathrm{Nd} 140 \mathrm{~m} 1$ & $\dagger 43 \mathrm{Tc} 97$ & $(\mathrm{n}, 2 \mathrm{NT})$ & $42 \mathrm{Mo} 93$ \\
\hline$* 61 \mathrm{Pm} 143$ & $(\mathrm{n}, 2 \mathrm{~N})$ & $61 \mathrm{Pm} 142 \mathrm{~m} 1$ & $\dagger 43 \mathrm{Tc} 97 \mathrm{~m} 1$ & $(\mathrm{n}, 2 \mathrm{NT})$ & $42 \mathrm{Mo} 93$ \\
\hline
\end{tabular}




\begin{tabular}{|l|l|l||l|l|l|}
\cline { 3 - 6 }$* 65 \mathrm{~Tb} 152$ & $(\mathrm{n}, \mathrm{NA})$ & $63 \mathrm{Eu} 148 \mathrm{~m} 1$ & $\dagger 52 \mathrm{Te} 123 \mathrm{~m} 1$ & $(\mathrm{n}, 2 \mathrm{NT})$ & $51 \mathrm{Sb} 119$ \\
\hline$* 65 \mathrm{~Tb} 152$ & $(\mathrm{n}, \mathrm{G})$ & $65 \mathrm{~Tb} 153 \mathrm{~m} 1$ & $\$ 73 \mathrm{Ta} 180$ & $(\mathrm{n}, 3 \mathrm{~N})$ & $73 \mathrm{Ta} 178 \mathrm{~m} 1$ \\
\hline$* 74 \mathrm{~W} 181$ & $(\mathrm{n}, 2 \mathrm{~N})$ & $74 \mathrm{~W} 180 \mathrm{~m} 1$ & $\$ 74 \mathrm{~W} 181$ & $\begin{array}{l}(\mathrm{n}, 2 \mathrm{ND} N \mathrm{NT} \\
3 \mathrm{NP})\end{array}$ & $73 \mathrm{Ta} 178 \mathrm{~m} 1$ \\
\hline$* 79 \mathrm{Au} 198$ & $(\mathrm{n}, \mathrm{G})$ & $79 \mathrm{Au} 199 \mathrm{~m} 1$ & $\$ 82 \mathrm{~Pb} 202$ & $(\mathrm{n}, \mathrm{G})$ & $82 \mathrm{~Pb} 203 \mathrm{~m} 1$ \\
\hline$* 82 \mathrm{~Pb} 202$ & $(\mathrm{n}, \mathrm{G})$ & $82 \mathrm{~Pb} 203 \mathrm{~m} 2$ & $\$ 83 \mathrm{Bi} 203$ & $(\mathrm{n}, 2 \mathrm{NA})$ & $81 \mathrm{~T} 1198 \mathrm{~m} 1$ \\
\hline$* 83 \mathrm{Bi} 203$ & $(\mathrm{n}, 2 \mathrm{NA})$ & $81 \mathrm{~T} 1198 \mathrm{~m} 2$ & & & \\
\hline
\end{tabular}

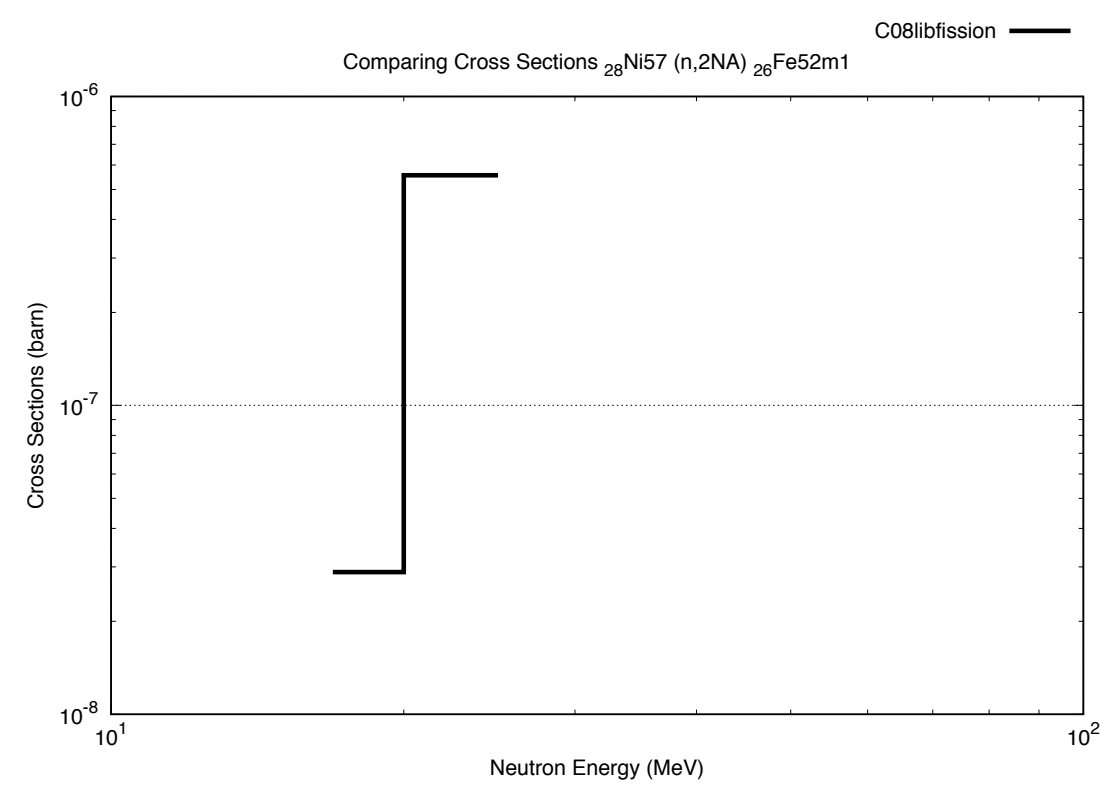

(a)

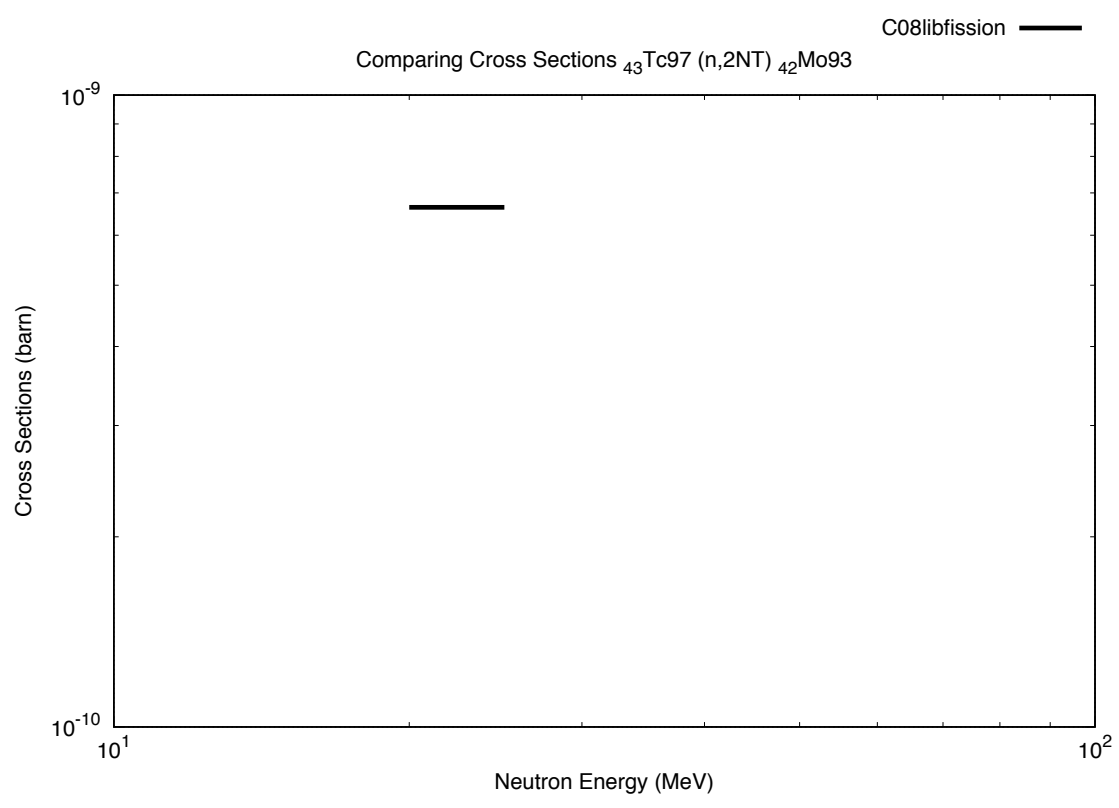

(b) 


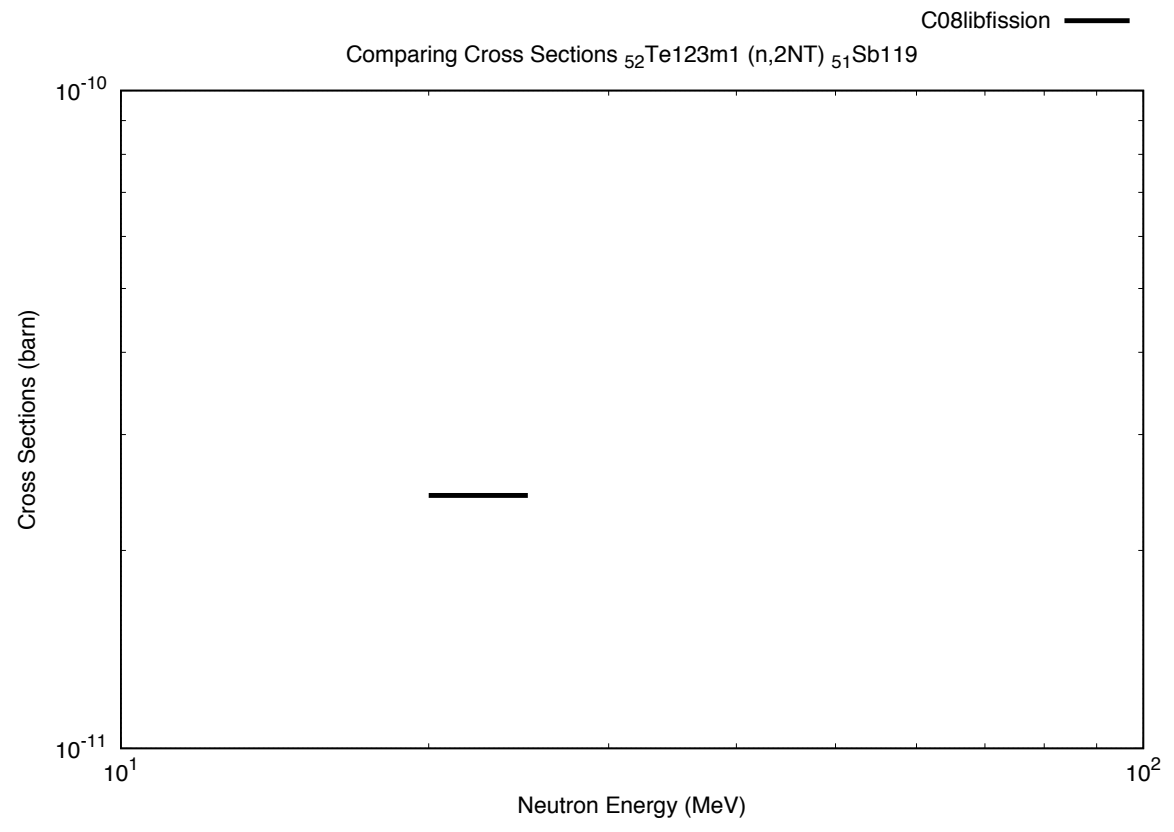

(c)

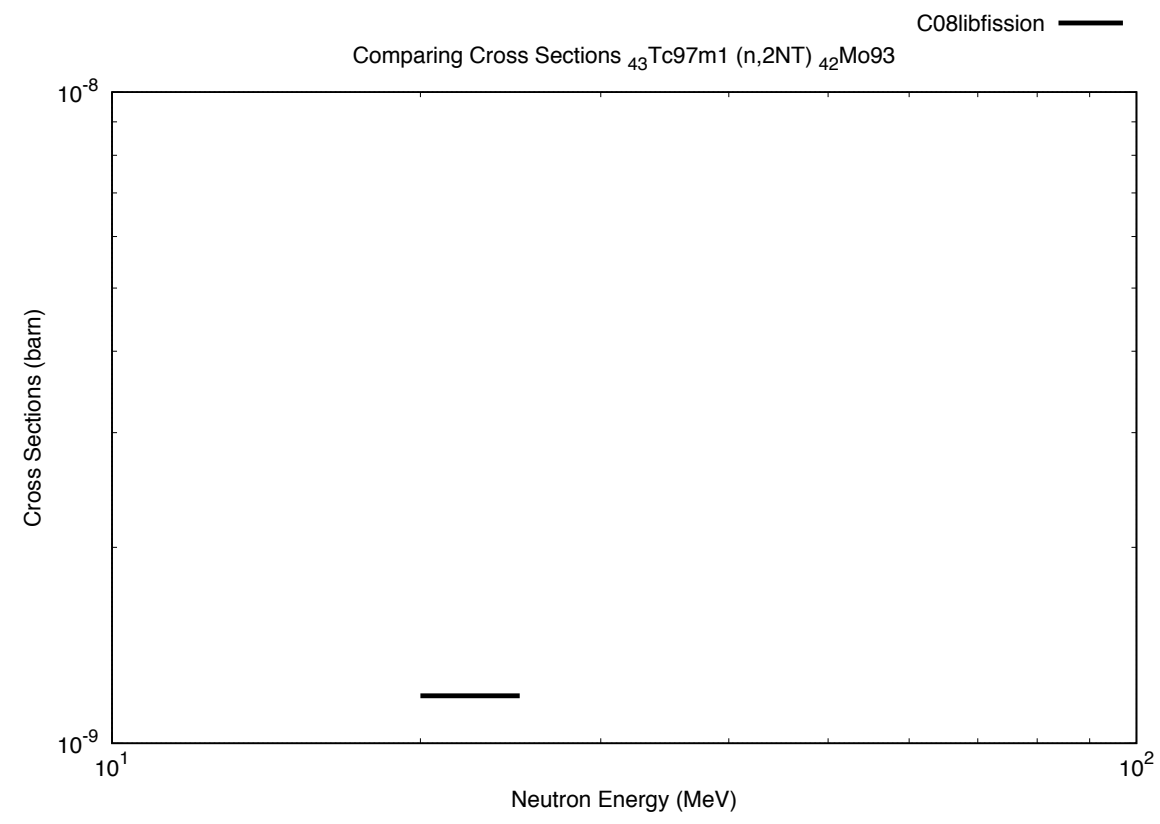

(d)

Figure 2. Four reaction cross sections in EAF-2010 (as of July 22, 2016) with their threshold energy higher than the upper limit energy bin of the group structure in the updated CINDER2008 fission-weighted library.

The remaining four reactions, marked ( $\ddagger$ ) in Table 3, are also presented in EAF-2010, but they are not shown in the updated fission-weighted library due to the treatment of the incomplete isomers in the CINDER2008 library maker tool. One such example as shown in Fig. 3 is $82 P b 202(n, G) 82 P b 203 m 1$, 
whose product $\mathrm{Pb} 203$ has three isomers, one ground state and two metastable states. In the current CINDER2008 fission-weighted library, production cross sections of all three isomers are presented for the $(\mathrm{n}, \mathrm{G})$ reaction of $\mathrm{Pb} 202$. However, in EAF-2010 the production cross sections of $\mathrm{Pb} 203 \mathrm{~m} 2$ is now not included resulting in an incomplete list of production cross sections for $\mathrm{Pb} 203$. In dealing with such a situation, the CINDER2008 library maker tool sums the production cross sections of $\mathrm{Pb} 203$ and $\mathrm{Pb} 203 \mathrm{~m} 1$ and groups it under Pb203. As observed in Fig. 3(c), the $82 \mathrm{~Pb} 202(n, G) 82 \mathrm{~Pb} 203$ reaction cross sections in the updated library (red line) is slightly higher than those in the current one (black line).

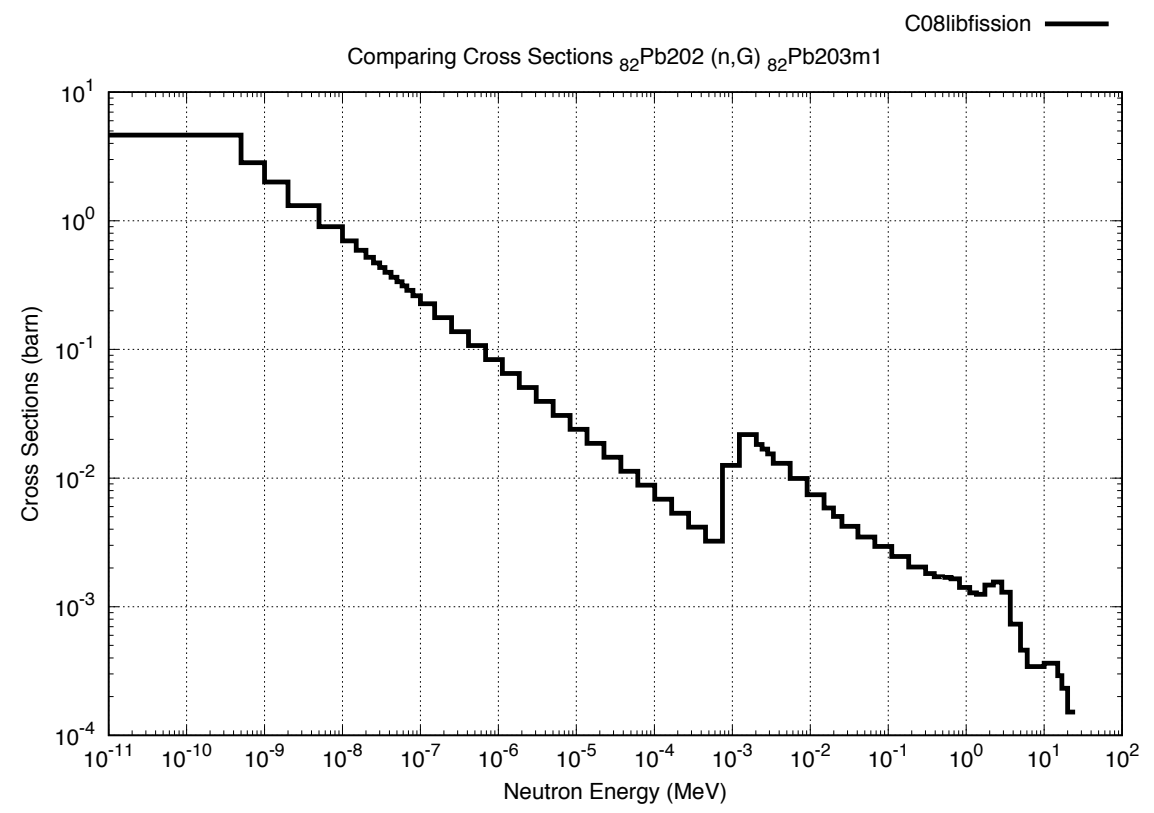

(a)

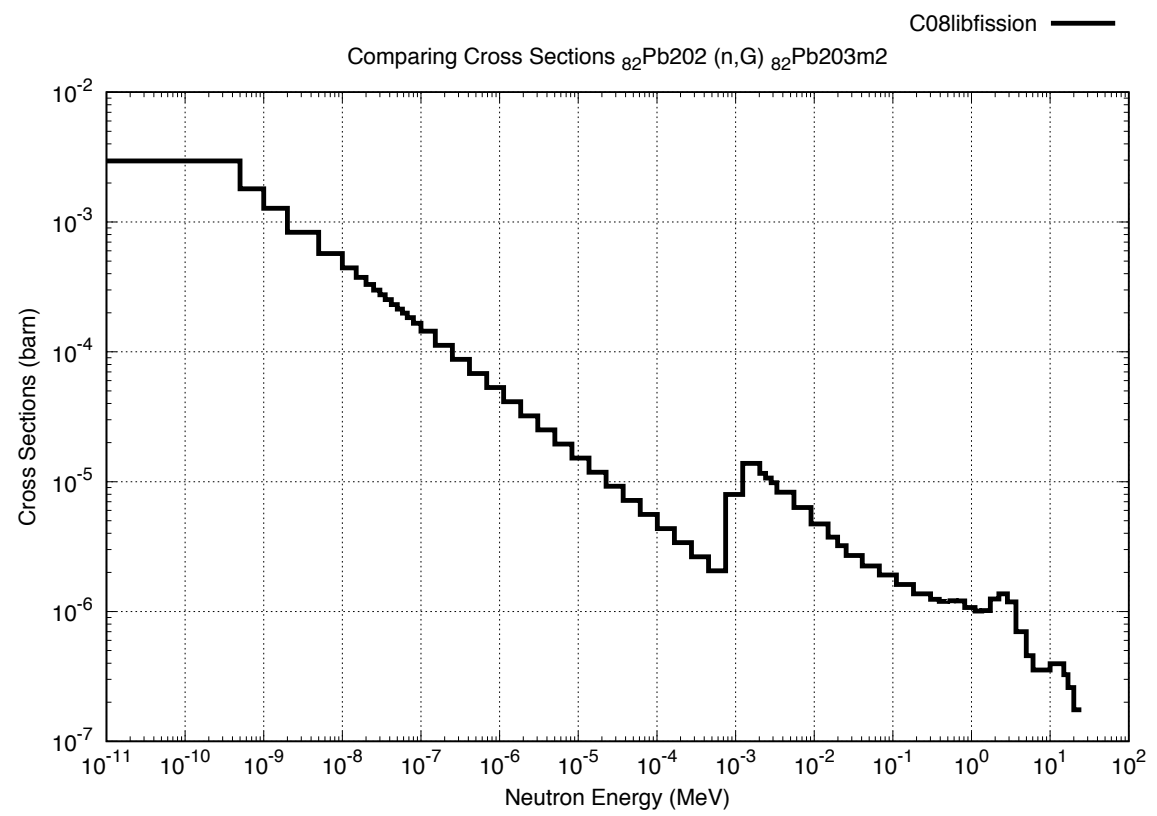

(b) 


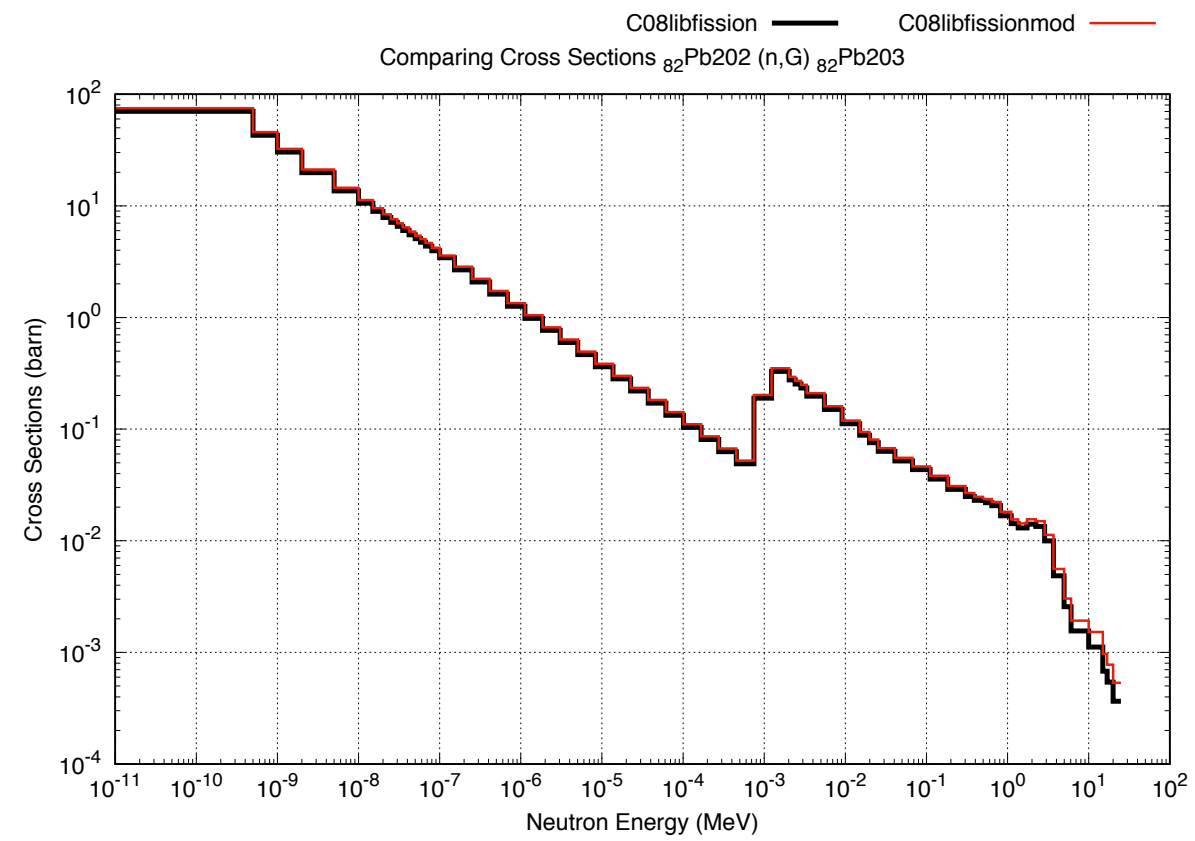

(c)

Figure 3. Production cross sections of $\mathrm{Pb} 203$ and its isomers through $(\mathrm{n}, \mathrm{G})$ reaction in the current and updated CINDER2008 fission-weighted library.

There are 14 reaction cross sections, listed in Table 4, presented in the updated CINDER2008 fissionweighted library but not in the current one. As illustrated in Fig. 4 for some of the list, these reactions all have cross sections barely above the library maker tool's cut-off of 1E-12 barns, and only in the highest one or two energy groups.

Table 4. List of fourteen reaction cross sections not present in the current CINDER2008 fission-weighted library but present in the updated CINDER2008 fission-weighted library.

\begin{tabular}{|l|l|l|}
\hline Target Nucl. & Reactions & Product Nucl. \\
\hline $31 \mathrm{Ga} 66$ & $(\mathrm{n}, 3 \mathrm{~A})$ & $25 \mathrm{Mn} 55$ \\
\hline $47 \mathrm{Ag} 108 \mathrm{~m} 1$ & $(\mathrm{n}, 3 \mathrm{NA})$ & $45 \mathrm{Rh} 102 \mathrm{~m} 1$ \\
\hline $54 \mathrm{Xe} 131 \mathrm{~m} 1$ & $(\mathrm{n}, 3 \mathrm{NA})$ & $52 \mathrm{Te} 125 \mathrm{~m} 1$ \\
\hline $60 \mathrm{Nd} 140$ & $(\mathrm{n}, 3 \mathrm{NA})$ & $58 \mathrm{Ce} 134$ \\
\hline $64 \mathrm{Gd} 147$ & $(\mathrm{n}, \mathrm{P} 3 \mathrm{HE})$ & $61 \mathrm{Pm} 144$ \\
\hline $67 \mathrm{Ho} 163$ & $(\mathrm{n}, 2 \mathrm{NT})$ & $66 \mathrm{Dy} 159$ \\
\hline $69 \mathrm{Tm} 173$ & $(\mathrm{n}, 2 \mathrm{P})$ & $67 \mathrm{Ho} 172$ \\
\hline 78Pt195 & $(\mathrm{n}, 2 \mathrm{NT})$ & $77 \mathrm{Ir} 191$ \\
\hline $79 \mathrm{Au} 196$ & $(\mathrm{n}, \mathrm{NPA})$ & $76 \mathrm{Os} 191 \mathrm{~m} 1$ \\
\hline $81 \mathrm{~T} 1201$ & $(\mathrm{n}, 2 \mathrm{~A})$ & $77 \mathrm{Ir} 194 \mathrm{~m} 1$ \\
\hline $81 \mathrm{~T} 1201$ & $(\mathrm{n}, 2 \mathrm{~A})$ & $77 \mathrm{Ir} 194 \mathrm{~m} 2$ \\
\hline $82 \mathrm{~Pb} 201$ & $(\mathrm{n}, \mathrm{NPA})$ & $79 \mathrm{Au} 196 \mathrm{~m} 1$ \\
\hline $82 \mathrm{~Pb} 201$ & $(\mathrm{n}, \mathrm{NPA})$ & $79 \mathrm{Au} 196 \mathrm{~m} 2$ \\
\hline $83 \mathrm{Bi} 210 \mathrm{~m} 1$ & $(\mathrm{n}, 4 \mathrm{NA})$ & $81 \mathrm{~T} 1203$ \\
\hline
\end{tabular}




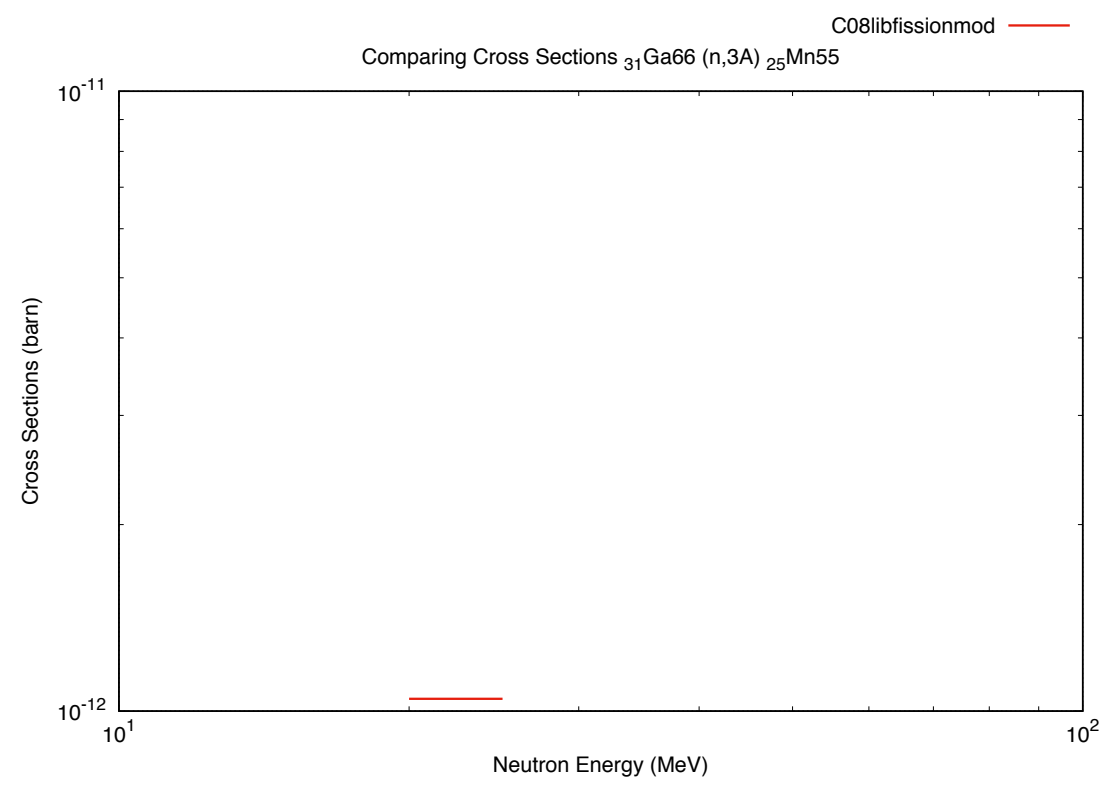

(a)

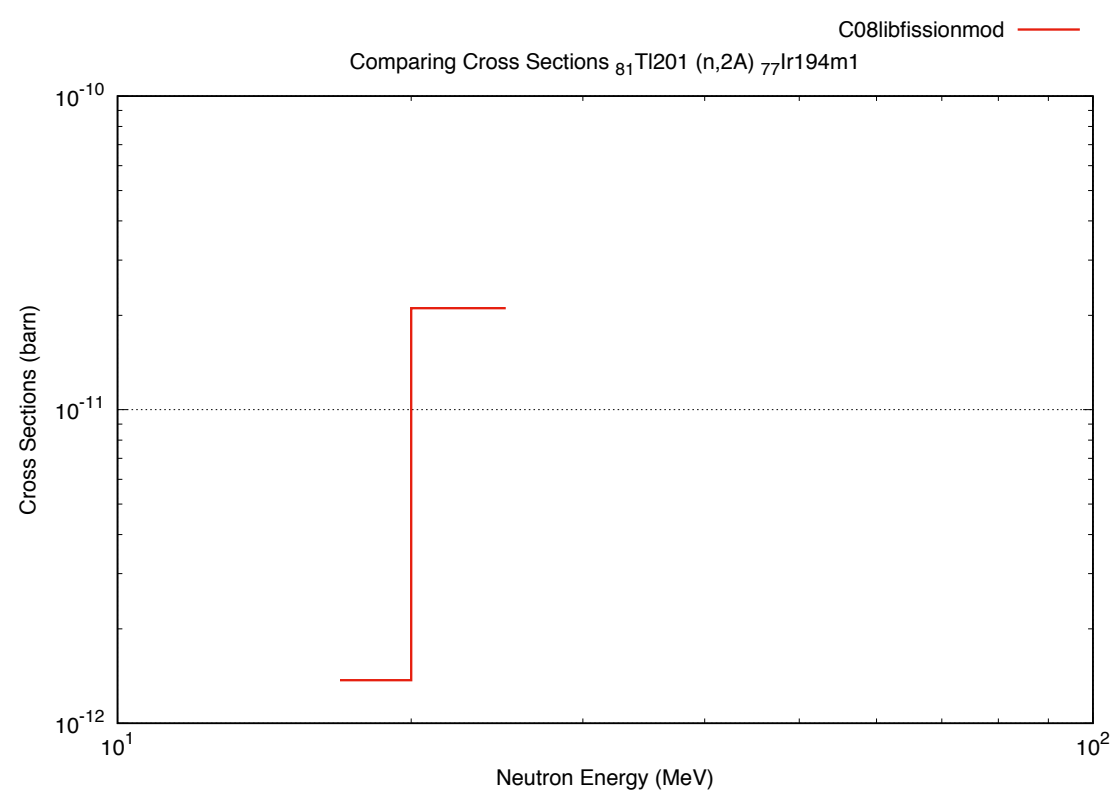

(b)

Figure 4. Two examples of reaction cross sections appearing in the updated CINDER2008 fission-weighted library but not present in the current CINDER2008 fission-weighted library.

The majority of $\sim 17,000$ reaction cross sections in both versions of the CINDER2008 fission-weighted library are consistent with each other. There are nevertheless 151 reactions whose cross sections show significant difference (significant difference in this report is defined as ratios of cross sections in one or more energy groups are greater than 2) between the two versions. But most of them as illustrated in Fig. 5 just have one or two energy groups with more than a factor of 2 in difference while the cross sections in the rest of the spectrum are in line with each other. However, for the reactions listed in Table 5, where all of the products are in metastable states, the difference involves most of the energy groups. The comparison of those 6 reaction cross sections are plotted in Fig. 6 for the current and updated 
CINDER2008 fission-weighted library. Such a big difference is probably due to the revision of the branching ratios for the metastable states in EAF-2010.

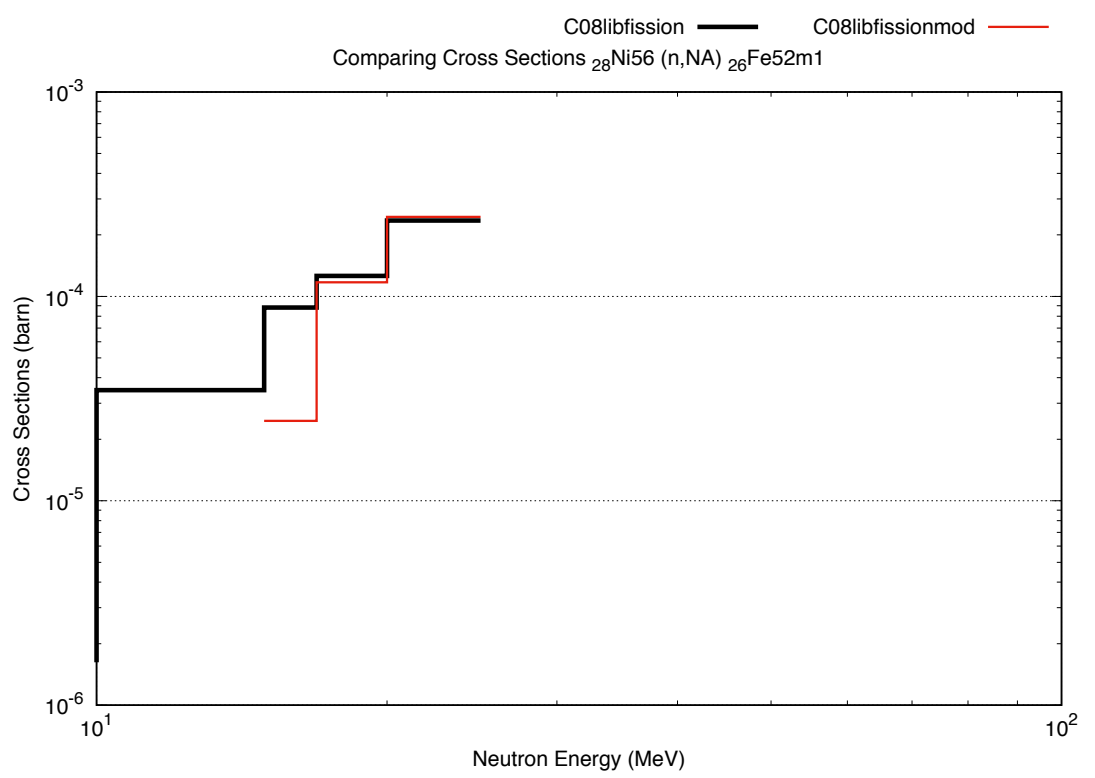

(a)

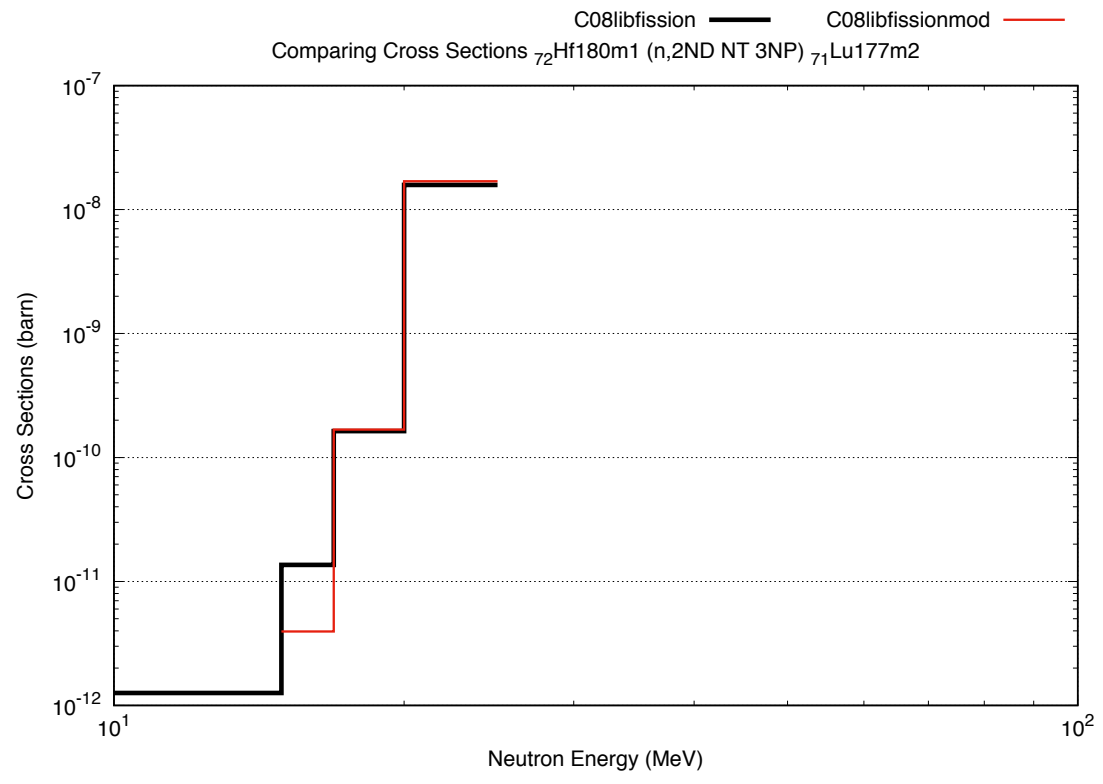

(b) 


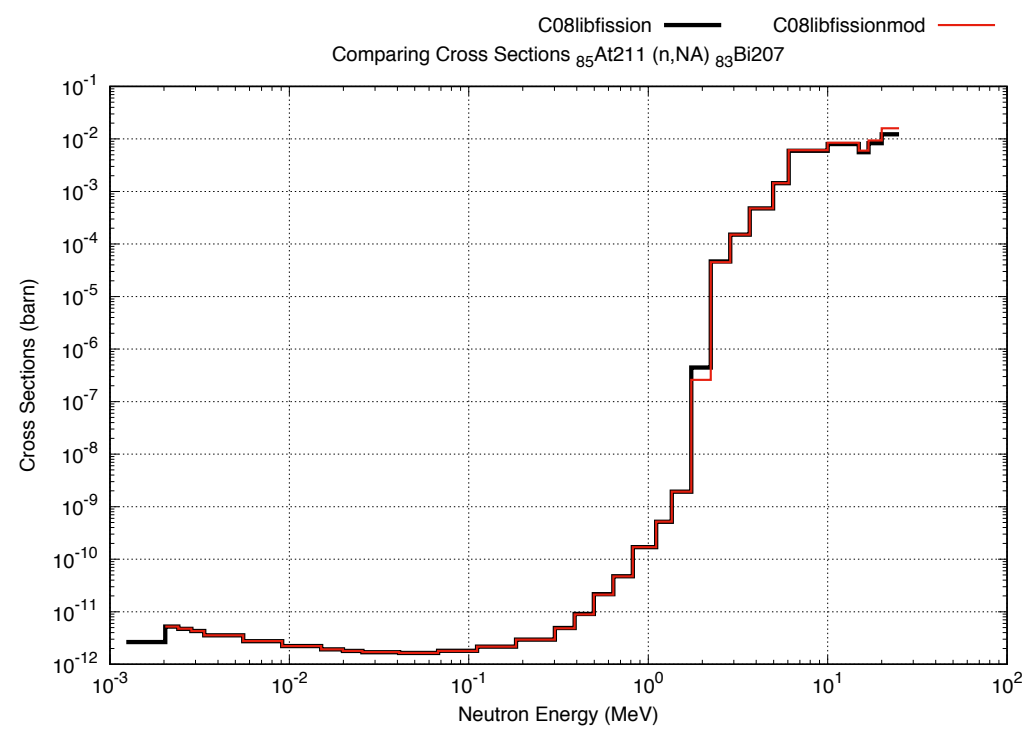

(c)

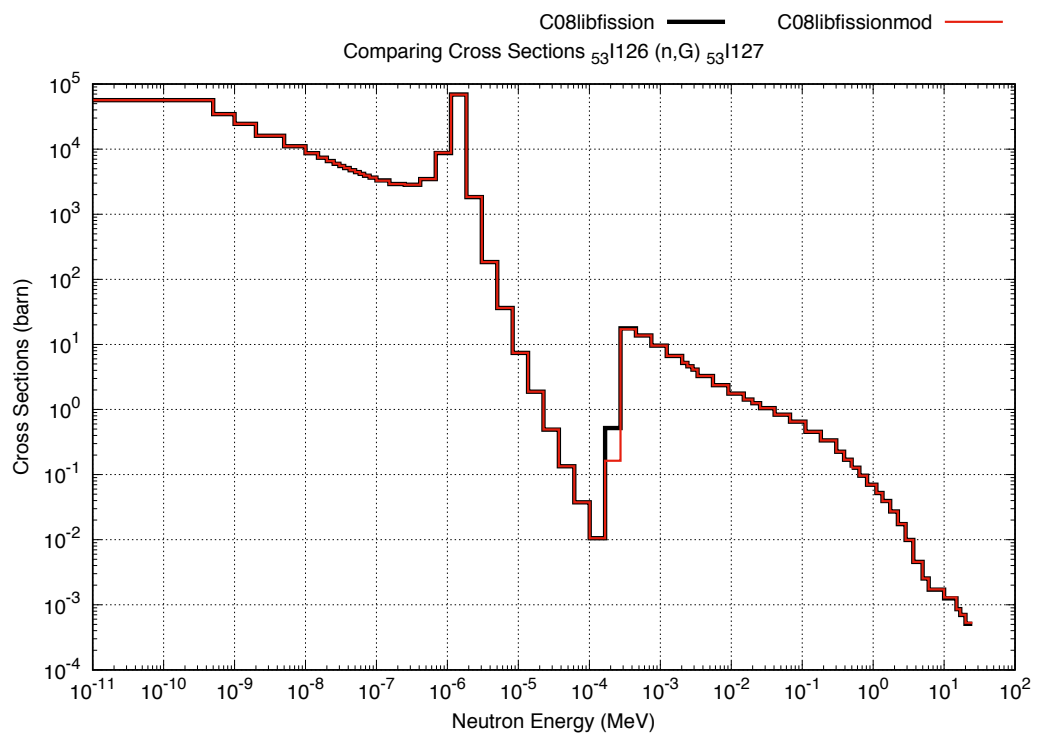

(d) 


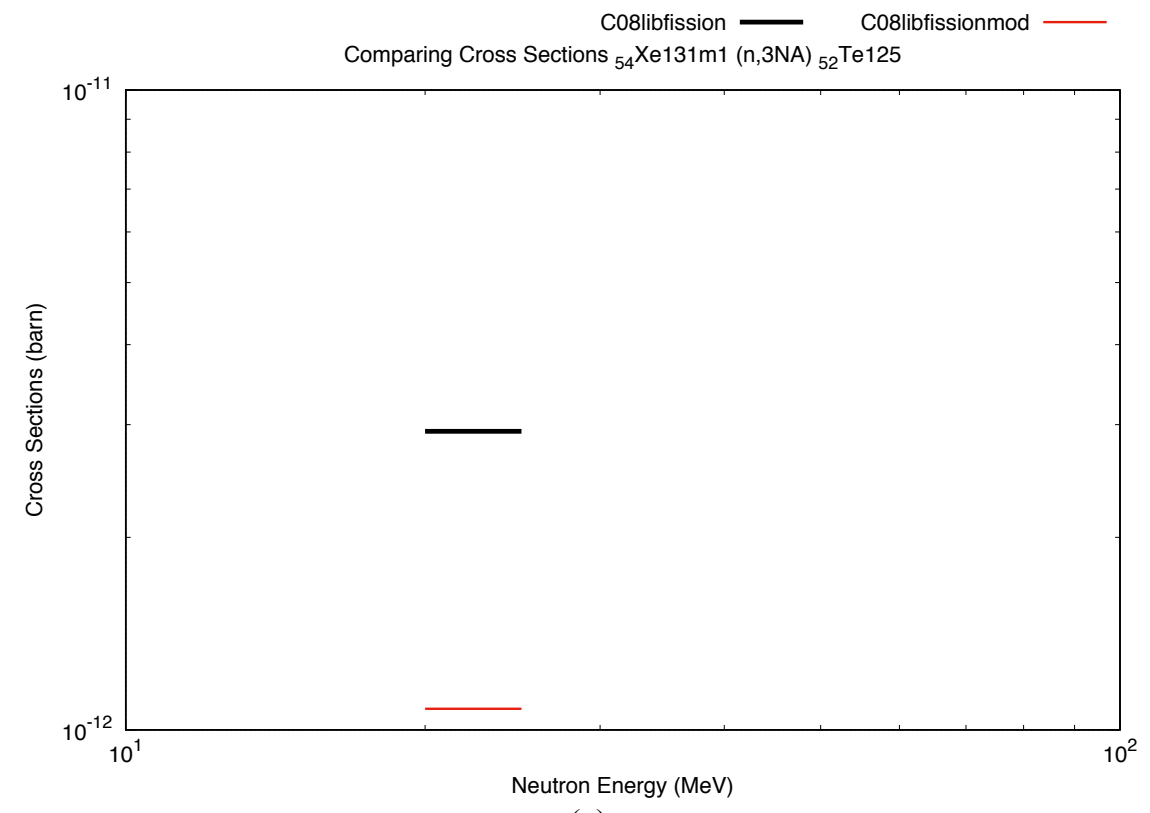

(e)

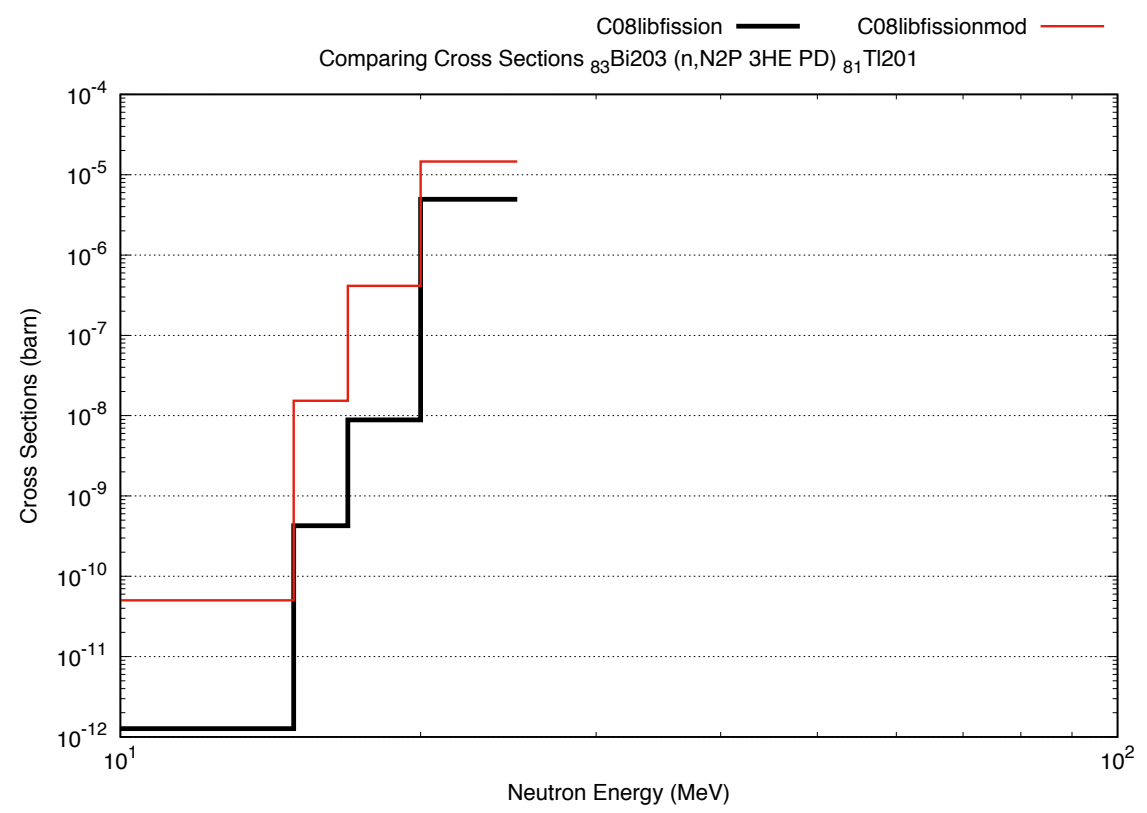

(f)

Figure 5. Examples of reaction cross sections showing significant differences between the current and updated CINDER2008 fission-weighted library, but that are not of serious concern. 
Table 5. List of six reaction cross sections with significant difference between the current and updated CINDER2008 fission libraries which are of serious concern.

\begin{tabular}{|l|c|l|}
\hline Target Nucl. & Reactions & Product Nucl. \\
\hline $72 \mathrm{Hf} 178 \mathrm{~m} 2$ & $(\mathrm{n}, \mathrm{G})$ & $72 \mathrm{Hf} 179 \mathrm{~m} 2$ \\
\hline $77 \mathrm{Ir} 190$ & $(\mathrm{n}, \mathrm{G})$ & $77 \mathrm{Ir} 191 \mathrm{~m} 2$ \\
\hline $79 \mathrm{Au} 195$ & $(\mathrm{n}, \mathrm{G})$ & $79 \mathrm{Au} 196 \mathrm{~m} 2$ \\
\hline $81 \mathrm{~T} 1205$ & $(\mathrm{n}, \mathrm{G})$ & $81 \mathrm{~T} 1206 \mathrm{~m} 1$ \\
\hline $78 \mathrm{Pt} 196$ & $(\mathrm{n}, \mathrm{G})$ & $78 \mathrm{Pt} 197 \mathrm{~m} 1$ \\
\hline $79 \mathrm{Au} 199$ & $(\mathrm{n}, \mathrm{G})$ & $79 \mathrm{Au} 200 \mathrm{~m} 1$ \\
\hline
\end{tabular}

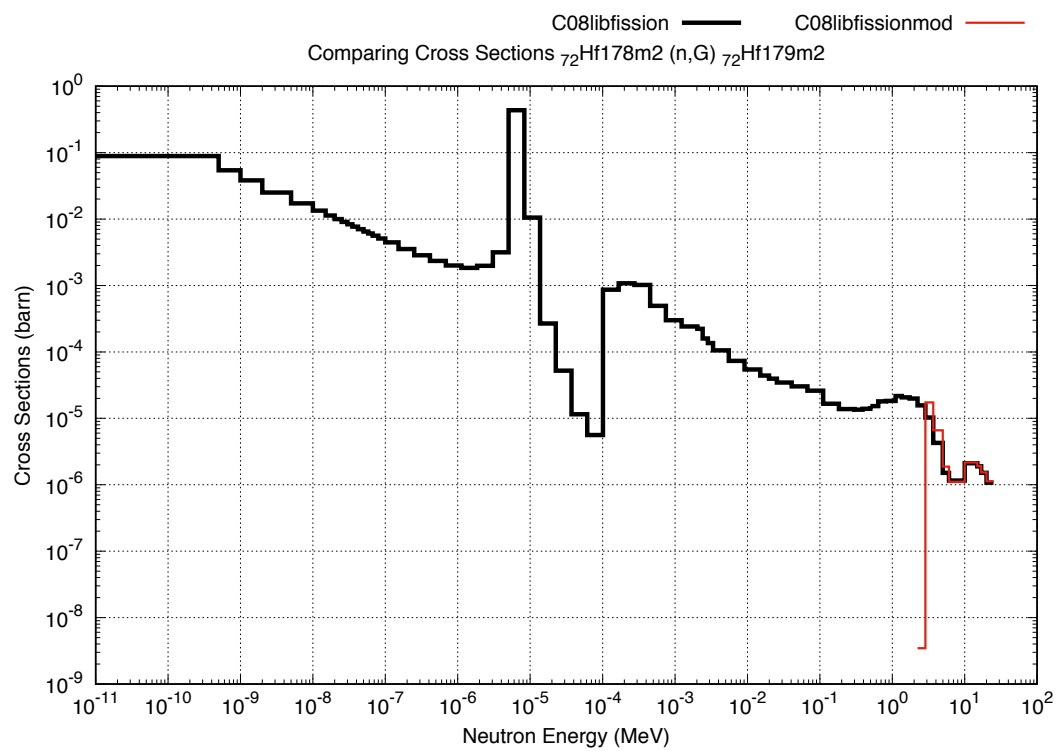

(a)

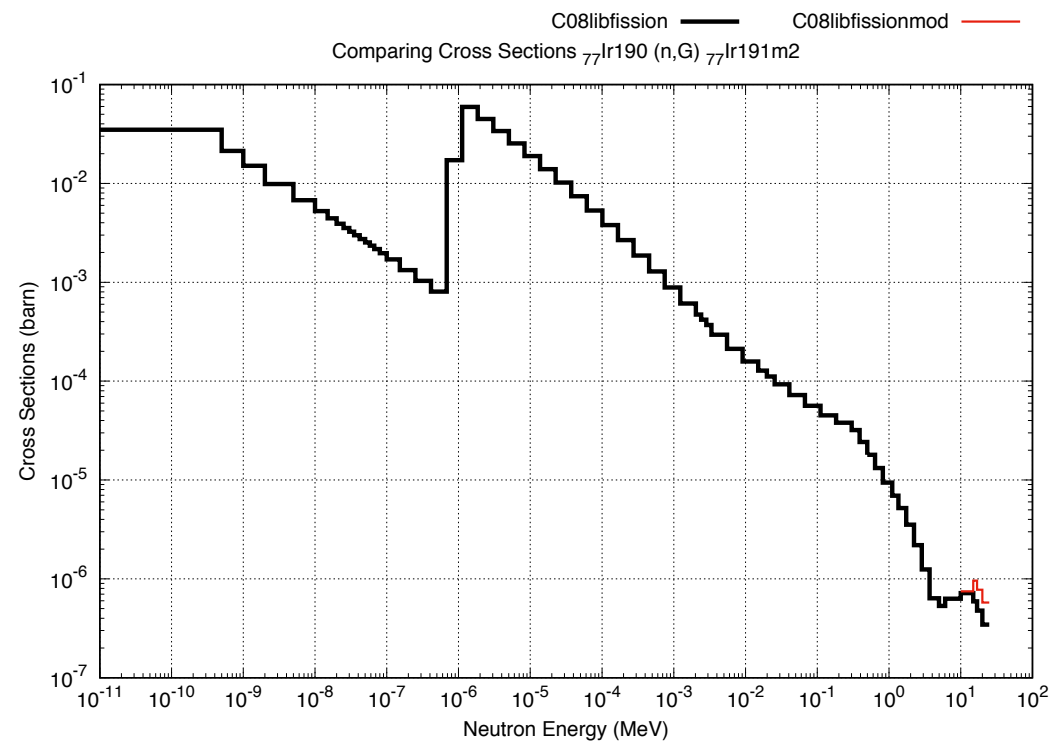

(b) 


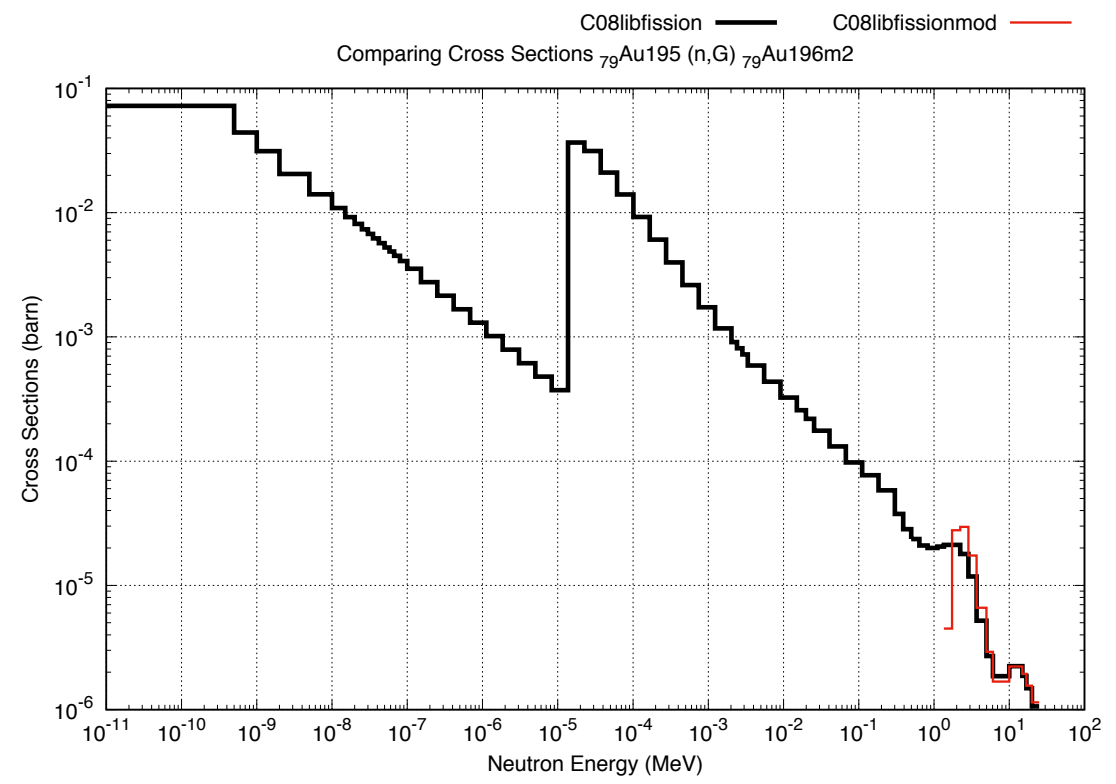

(c)

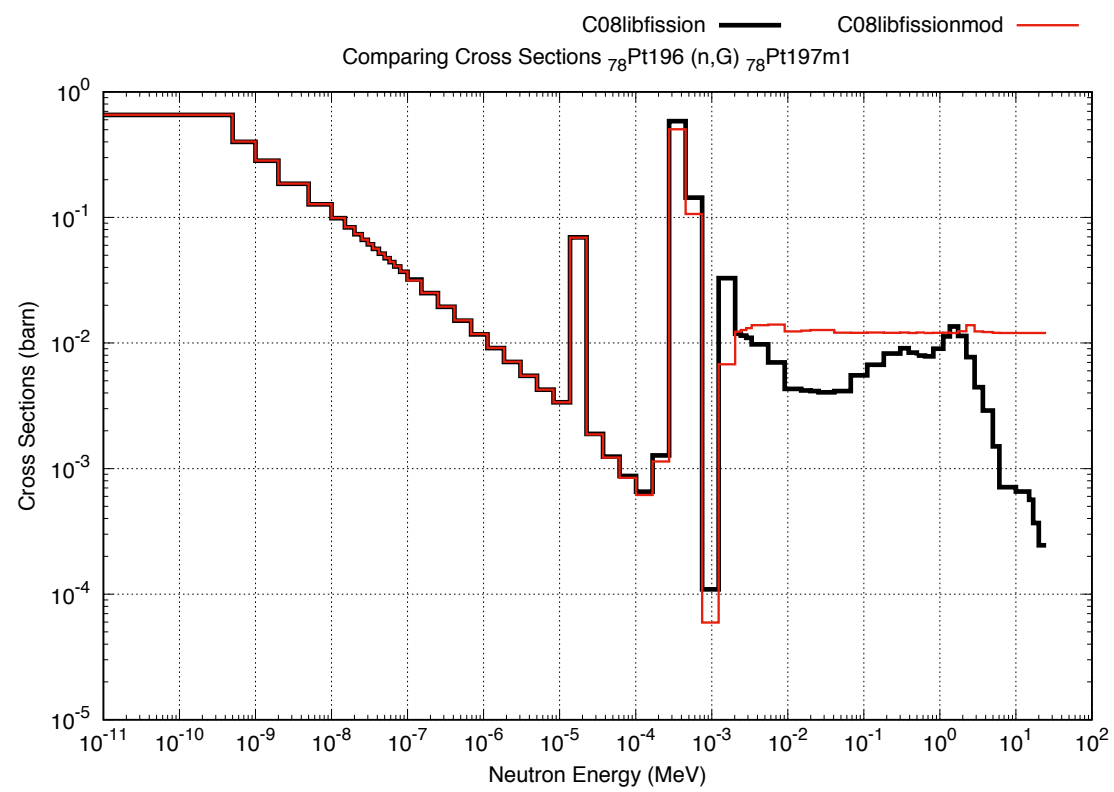

(d) 


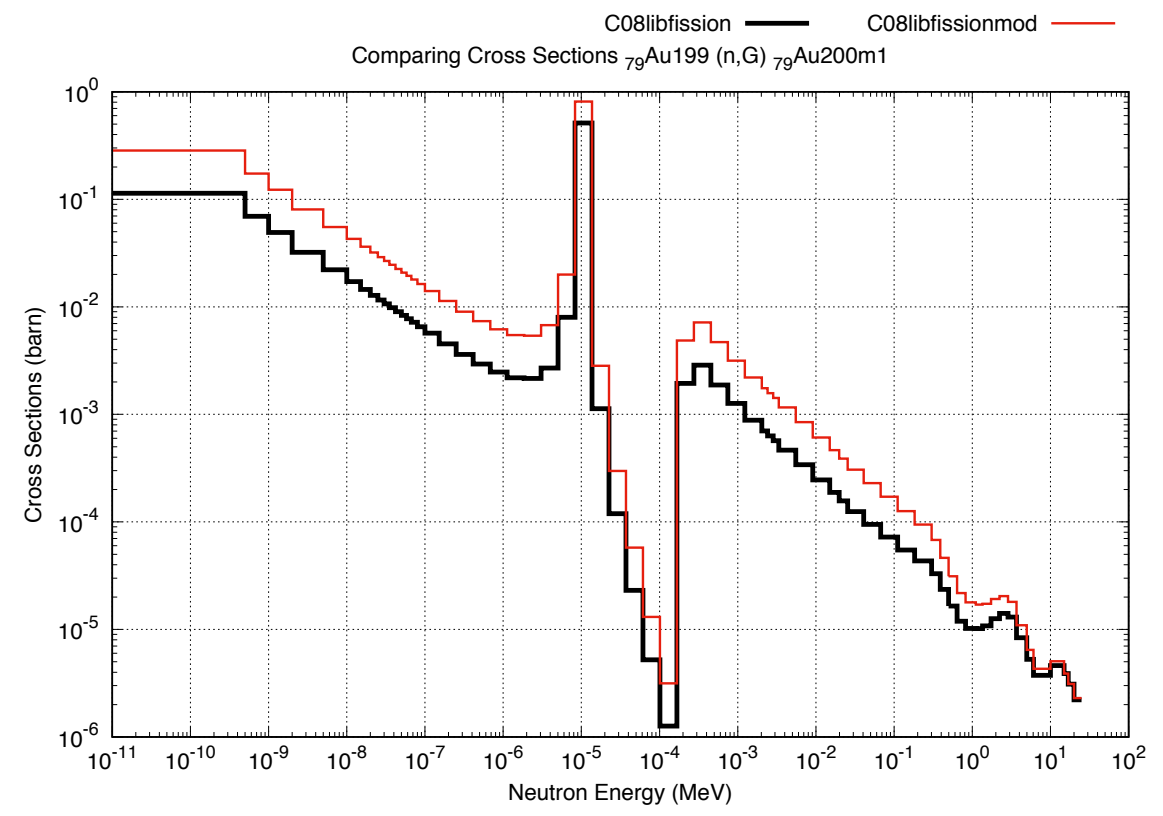

(e)

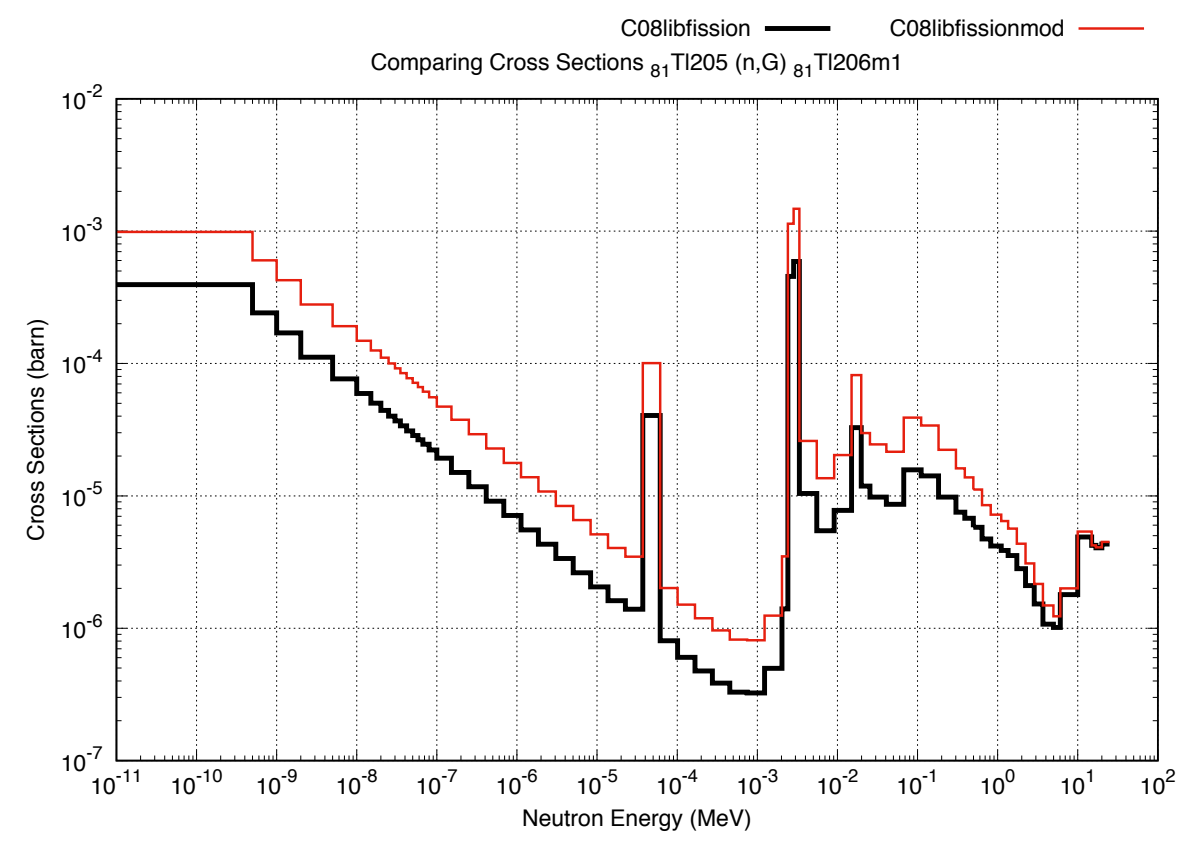

(f)

Figure 6. Six reaction cross sections showing significant difference between the current and updated CINDER2008 fission-weighted library which are of serious concern. 


\subsection{FLAT-WEIGHTED LIBRARY}

The flat cross section library in CINDER2008 has the same energy range as the fission library but it has a fine 321-group energy structure compared to fission's 66-group structure. As discussed above, the current flat-weighted library in CINDER2008 contains a considerable fraction of truncated cross sections sourced from EAF-2010 and needs to be updated. The results of the updated flat-weighted library are checked against the current one and are discussed below.

There are 37 reaction cross sections, as listed in Table 6, missing in the updated CINDER2008 flatweighted library though they are present in the current one. The list is very similar to that in Table 3 , so is the discussion for reactions marked $(*),(\dagger)$ and $(\dagger)$. One exception is reaction T1204 (n, 2A) Ir197m1 marked (**). This reaction cross section is included in EAF-2010, but as shown in Fig. 7 the single-group cross section of this reaction is insignificant and is very close to $1 \mathrm{E}-12$ barn, which is the inherently imposed cross section cut-off limit in the library maker tool of CINDER2008. The presence or disappearance of this reaction is probably due to the treatment of the CINDER2008 library maker tool.

Table 6. List of 37 reaction cross sections in the current CINDER2008 flat-weighted library but not in the updated CINDER2008 flat-weighted library.

\begin{tabular}{|c|c|c|c|c|c|}
\hline $\begin{array}{l}\text { Target } \\
\text { Nucl. }\end{array}$ & Reactions & $\begin{array}{l}\text { Product } \\
\text { Nucl. }\end{array}$ & Target Nucl. & Reactions & $\begin{array}{l}\text { Product } \\
\text { Nucl. }\end{array}$ \\
\hline$* 30 \mathrm{Zn} 62$ & $(\mathrm{n}, 2 \mathrm{~N})$ & $30 \mathrm{Zn} 61 \mathrm{~m} 1$ & *83Bi203 & $(\mathrm{n}, \mathrm{NA})$ & $81 \mathrm{~T} 1199 \mathrm{~m} 1$ \\
\hline *30Zn62 & $(\mathrm{n}, 2 \mathrm{~N})$ & $30 \mathrm{Zn} 61 \mathrm{~m} 2$ & *83Bi203 & $(\mathrm{n}, \mathrm{N} 3 \mathrm{HE}$ A PT) & $81 \mathrm{~T} 1200 \mathrm{~m} 1$ \\
\hline *30Zn62 & $(\mathrm{n}, 2 \mathrm{~N})$ & $30 \mathrm{Zn} 61 \mathrm{~m} 3$ & *83Bi203 & $\begin{array}{l}(\mathrm{n}, \mathrm{N} 2 \mathrm{P} 3 \mathrm{HE} \\
\mathrm{PD})\end{array}$ & $81 \mathrm{~T} 1201 \mathrm{~m} 1$ \\
\hline *52Te129 & $(\mathrm{n}, 2 \mathrm{~N})$ & $52 \mathrm{Te} 128 \mathrm{~m} 1$ & *84Po206 & $(\mathrm{n}, \mathrm{NPA} D A)$ & $81 \mathrm{~T} 1201 \mathrm{~m} 1$ \\
\hline *56Ba129 & $(\mathrm{n}, \mathrm{ND} 2 \mathrm{NP} T)$ & $55 \mathrm{Cs} 127 \mathrm{~m} 1$ & *84Po206 & $(\mathrm{n}, 2 \mathrm{~N})$ & $84 \mathrm{Po} 205 \mathrm{~m} 1$ \\
\hline *56Ba129 & $(n, G)$ & $56 \mathrm{Ba} 130 \mathrm{~m} 1$ & *84Po206 & $(\mathrm{n}, 2 \mathrm{~N})$ & $84 \mathrm{Po} 205 \mathrm{~m} 2$ \\
\hline *58Ce134 & $(\mathrm{n}, \mathrm{NA})$ & $56 \mathrm{Ba} 130 \mathrm{~m} 1$ & *85At211 & $(\mathrm{n}, 2 \mathrm{~A})$ & $81 \mathrm{~T} 1204 \mathrm{~m} 1$ \\
\hline *58Ce134 & $(\mathrm{n}, 3 \mathrm{~N})$ & $58 \mathrm{Ce} 132 \mathrm{~m} 1$ & $* 85$ At211 & $(\mathrm{n}, 2 \mathrm{NA})$ & 83Bi206m1 \\
\hline *58Ce137 & $(\mathrm{n}, 2 \mathrm{~N})$ & $58 \mathrm{Ce} 136 \mathrm{~m} 1$ & *85At211 & $(\mathrm{n}, \mathrm{NA})$ & $83 \mathrm{Bi} 207 \mathrm{~m} 1$ \\
\hline *58Ce137 & $(n, G)$ & $58 \mathrm{Ce} 138 \mathrm{~m} 1$ & $\dagger 28 \mathrm{Ni} 57$ & $(\mathrm{n}, 2 \mathrm{NA})$ & $26 \mathrm{Fe} 52 \mathrm{~m} 1$ \\
\hline *61Pm143 & $(\mathrm{n}, \mathrm{NPA}$ DA $)$ & $58 \mathrm{Ce} 138 \mathrm{~m} 1$ & $\dagger 43 \mathrm{Tc} 97$ & $(\mathrm{n}, 2 \mathrm{NT})$ & $42 \mathrm{Mo} 93$ \\
\hline *61Pm143 & $(\mathrm{n}, \mathrm{NT})$ & $60 \mathrm{Nd} 140 \mathrm{~m} 1$ & $\dagger 43 \mathrm{Tc} 97 \mathrm{~m} 1$ & $(\mathrm{n}, 2 \mathrm{NT})$ & 42Mo93 \\
\hline *61Pm143 & $(\mathrm{n}, 2 \mathrm{~N})$ & $61 \mathrm{Pm} 142 \mathrm{~m} 1$ & $\dagger 52 \mathrm{Te} 123 \mathrm{~m} 1$ & $(\mathrm{n}, 2 \mathrm{NT})$ & $51 \mathrm{Sb} 119$ \\
\hline *65Tb152 & $(\mathrm{n}, \mathrm{NA})$ & 63Eu148m1 & $\$ 73 \mathrm{Ta} 180$ & $(\mathrm{n}, 3 \mathrm{~N})$ & $73 \mathrm{Ta} 178 \mathrm{~m} 1$ \\
\hline$* 65 \mathrm{~Tb} 152$ & $(n, G)$ & $65 \mathrm{~Tb} 153 \mathrm{~m} 1$ & $\$ 74 \mathrm{~W} 181$ & $\begin{array}{l}(\mathrm{n}, 2 \mathrm{ND} \text { NT } \\
3 \mathrm{NP})\end{array}$ & $73 \mathrm{Ta} 178 \mathrm{~m} 1$ \\
\hline *74W 181 & $(\mathrm{n}, 2 \mathrm{~N})$ & 74W180m1 & $\$ 82 \mathrm{~Pb} 202$ & $(n, G)$ & $82 \mathrm{~Pb} 203 \mathrm{~m} 1$ \\
\hline *79Au198 & $(n, G)$ & 79Au199m1 & $\$ 83 \mathrm{Bi} 203$ & $(\mathrm{n}, 2 \mathrm{NA})$ & $81 \mathrm{~T} 1198 \mathrm{~m} 1$ \\
\hline *82Pb202 & $(\mathrm{n}, \mathrm{G})$ & $82 \mathrm{~Pb} 203 \mathrm{~m} 2$ & $* * 81 \mathrm{~T} 1204$ & $(\mathrm{n}, 2 \mathrm{~A})$ & 77Ir197m1 \\
\hline *83Bi203 & $(\mathrm{n}, 2 \mathrm{NA})$ & $81 \mathrm{~T} 1198 \mathrm{~m} 2$ & & & \\
\hline
\end{tabular}




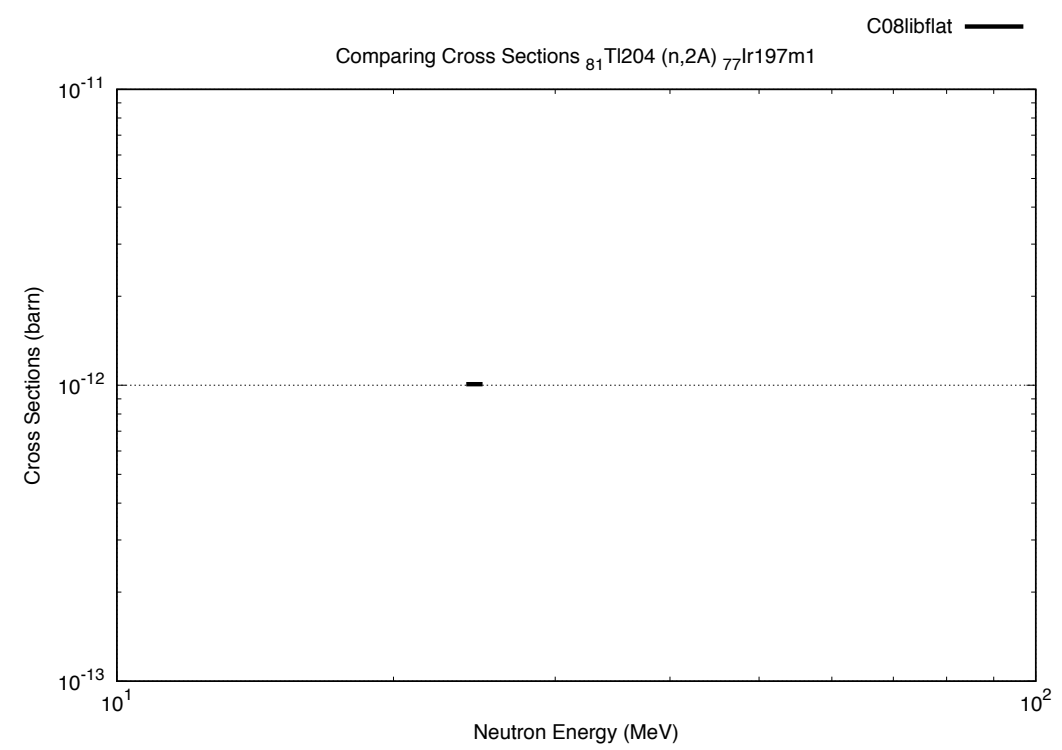

Figure 7. Reaction cross sections shown in the current CINDER2008 flat-weighted library but not in the updated one due to the cut-off treatment of the CINDER2008 library maker tool.

There are 170 reaction cross section in the updated CINDER2008 flat-weighted library that are not in the current CINDER2008 flat-weighted library. 167 of them as listed in Table 7 are actually significant and present in the current CINDER2008 fission-weighted library, which means they are accidentally missed in the current flat-weighted library during the cross section processing and are fixed by this update. Some of those cross sections are shown in Fig. 8. The remaining 3 reactions, whose cross sections are shown in Fig. 9, contains a few energy groups with insignificant cross sections slightly above the 1E-12 barn cutoff limit of the CINDER2008 library maker tool. As discussed above, they are probably due to the treatment of grouping in NJOY and treatment of the library maker tool in CINDER2008 and are not of concern. The same reason could be applied for those 14 reaction cross sections in Table 4 that appear in the updated fission-weighted library but not in the current fission-weighted library. They are all present in both the current and updated flat-weighted library.

Table 7. List of 167 reaction cross sections missing in the current CINDER2008 flat-weighted library but present in the updated CINDER2008 flat-weighted library.

\begin{tabular}{|l|l|l||l|l|l|}
\hline Target Nucl. & Reactions & $\begin{array}{l}\text { Product } \\
\text { Nucl. }\end{array}$ & Target Nucl. & Reactions & $\begin{array}{l}\text { Product } \\
\text { Nucl. }\end{array}$ \\
\hline $11 \mathrm{Na} 24$ & $(\mathrm{n}, \mathrm{N})$ & $11 \mathrm{Na} 24 \mathrm{~m} 1$ & $64 \mathrm{Gd} 147$ & $(\mathrm{n}, 3 \mathrm{HEA})$ & $60 \mathrm{Nd} 141 \mathrm{~m} 1$ \\
\hline $13 \mathrm{~A} 126$ & $(\mathrm{n}, \mathrm{N})$ & $13 \mathrm{~A} 126 \mathrm{~m} 1$ & $64 \mathrm{Gd} 147$ & $(\mathrm{n}, 2 \mathrm{P})$ & $62 \mathrm{Sm} 146$ \\
\hline $25 \mathrm{Mn} 52$ & $(\mathrm{n}, \mathrm{N})$ & $25 \mathrm{Mn} 52 \mathrm{~m} 1$ & $64 \mathrm{Gd} 150$ & $(\mathrm{n}, \mathrm{P})$ & $63 \mathrm{Eu} 150$ \\
\hline $30 \mathrm{Zn} 62$ & $(\mathrm{n}, 2 \mathrm{~A})$ & $26 \mathrm{Fe} 55$ & $64 \mathrm{Gd} 150$ & $(\mathrm{n}, \mathrm{P})$ & $63 \mathrm{Eu} 150 \mathrm{~m} 1$ \\
\hline $33 \mathrm{As} 77$ & $(\mathrm{n}, \mathrm{A})$ & $31 \mathrm{Ga} 74 \mathrm{~m} 1$ & $64 \mathrm{Gd} 159$ & $(\mathrm{n}, \mathrm{NA})$ & $62 \mathrm{Sm} 155$ \\
\hline $34 \mathrm{Se} 73$ & $(\mathrm{n}, 3 \mathrm{~A})$ & $28 \mathrm{Ni} 62$ & $65 \mathrm{~Tb} 152$ & $(\mathrm{n}, 2 \mathrm{~N} 2 \mathrm{~A})$ & $61 \mathrm{Pm} 143$ \\
\hline $34 \mathrm{Se} 73$ & $(\mathrm{n}, \mathrm{PA})$ & $31 \mathrm{Ga} 69$ & $65 \mathrm{~Tb} 152$ & $(\mathrm{n}, \mathrm{N})$ & $65 \mathrm{~Tb} 152 \mathrm{~m} 1$ \\
\hline $36 \mathrm{Kr} 81$ & $(\mathrm{n}, \mathrm{N})$ & $36 \mathrm{Kr} 81 \mathrm{~m} 1$ & $65 \mathrm{~Tb} 154$ & $(\mathrm{n}, \mathrm{N})$ & $65 \mathrm{~Tb} 154 \mathrm{~m} 1$ \\
\hline $37 \mathrm{Rb} 8 \mathrm{~m} 1$ & $(\mathrm{n}, \mathrm{PA})$ & $34 \mathrm{Se} 78$ & $65 \mathrm{~Tb} 154$ & $(\mathrm{n}, \mathrm{N})$ & $65 \mathrm{~Tb} 154 \mathrm{~m} 2$ \\
\hline $37 \mathrm{Rb} 84$ & $(\mathrm{n}, \mathrm{N})$ & $37 \mathrm{Rb} 84 \mathrm{~m} 1$ & $65 \mathrm{~Tb} 158$ & $(\mathrm{n}, \mathrm{N} 2 \mathrm{~A})$ & $61 \mathrm{Pm} 150$ \\
\hline $38 \mathrm{Sr} 82$ & $(\mathrm{n}, 2 \mathrm{~A})$ & $34 \mathrm{Se} 75$ & $65 \mathrm{~Tb} 161$ & $(\mathrm{n}, \mathrm{NA})$ & $63 \mathrm{Eu} 157$ \\
\hline
\end{tabular}




\begin{tabular}{|c|c|c|c|c|c|}
\hline Target Nucl. & Reactions & $\begin{array}{l}\text { Product } \\
\text { Nucl. }\end{array}$ & Target Nucl. & Reactions & $\begin{array}{l}\text { Product } \\
\text { Nucl. }\end{array}$ \\
\hline $38 \mathrm{Sr} 83$ & $(\mathrm{n}, \mathrm{N})$ & $38 \mathrm{Sr} 83 \mathrm{~m} 1$ & 66Dy 153 & $(\mathrm{n}, 2 \mathrm{P})$ & $64 \mathrm{Gd} 152$ \\
\hline $38 \mathrm{Sr} 85$ & $(\mathrm{n}, 2 \mathrm{~A})$ & $34 \mathrm{Se} 78$ & 66Dy165 & $(\mathrm{n}, \mathrm{NA})$ & 64Gd161 \\
\hline $38 \mathrm{Sr} 85$ & $(\mathrm{n}, \mathrm{N})$ & $38 \mathrm{Sr} 85 \mathrm{~m} 1$ & 66Dy166 & $(\mathrm{n}, \mathrm{NA})$ & $64 \mathrm{Gd} 162$ \\
\hline $39 Y 86$ & $(\mathrm{n}, 2 \mathrm{~A})$ & $35 \mathrm{Br} 79 \mathrm{~m} 1$ & 67Ho163 & $(\mathrm{n}, \mathrm{N})$ & 67 Ho163m1 \\
\hline $39 Y 86$ & $(\mathrm{n}, \mathrm{PA})$ & $36 \mathrm{Kr} 82$ & $68 \mathrm{Er} 171$ & $(\mathrm{n}, \mathrm{NA})$ & 66 Dy 167 \\
\hline $39 Y 86$ & $(\mathrm{n}, \mathrm{N})$ & $39 \mathrm{Y} 86 \mathrm{~m} 1$ & $68 \mathrm{Er} 172$ & $(\mathrm{n}, \mathrm{NA})$ & $66 \mathrm{Dy} 168$ \\
\hline $39 Y 87$ & $(\mathrm{n}, \mathrm{N})$ & $39 Y 87 \mathrm{~m} 1$ & 69Tm171 & $(n, P)$ & $68 \operatorname{Er} 171$ \\
\hline $40 \mathrm{Zr} 86$ & $(\mathrm{n}, 2 \mathrm{~A})$ & $36 \mathrm{Kr} 79 \mathrm{~m} 1$ & 71Lu177 & $(n, P)$ & $70 \mathrm{Yb} 177$ \\
\hline $40 \mathrm{Zr} 89$ & $(\mathrm{n}, \mathrm{N})$ & $40 \mathrm{Zr} 89 \mathrm{~m} 1$ & 71Lu177 & $(n, P)$ & $70 \mathrm{Yb} 177 \mathrm{~m} 1$ \\
\hline $41 \mathrm{Nb} 90$ & $(\mathrm{n}, 2 \mathrm{~A})$ & $37 \mathrm{Rb} 83$ & 73Ta177 & $(\mathrm{n}, \mathrm{P})$ & 72Hf177m 1 \\
\hline $41 \mathrm{Nb} 90$ & $(\mathrm{n}, \mathrm{N})$ & $41 \mathrm{Nb} 90 \mathrm{~m} 2$ & 73Ta177 & $(\mathrm{n}, \mathrm{P})$ & $72 \mathrm{Hf} 177 \mathrm{~m} 2$ \\
\hline $41 \mathrm{Nb} 92 \mathrm{~m} 1$ & $(\mathrm{n}, 2 \mathrm{~A})$ & $37 \mathrm{Rb} 85$ & 73Ta179 & $(n, P)$ & $72 \mathrm{Hf} 179 \mathrm{~m} 1$ \\
\hline $41 \mathrm{Nb} 95 \mathrm{~m} 1$ & $(\mathrm{n}, 2 \mathrm{~A})$ & 37Rb88 & 73Ta179 & $(\mathrm{n}, \mathrm{P})$ & $72 \mathrm{Hf} 179 \mathrm{~m} 2$ \\
\hline $41 \mathrm{Nb} 96$ & $(\mathrm{n}, 2 \mathrm{~A})$ & $37 \mathrm{Rb} 89$ & 73Ta184 & $(\mathrm{n}, \mathrm{P})$ & $72 \mathrm{Hf1} 184$ \\
\hline 42Mo93 & $(\mathrm{n}, \mathrm{PA})$ & $39 \mathrm{Y} 89 \mathrm{~m} 1$ & 73Ta184 & $(\mathrm{n}, \mathrm{P})$ & 72Hf184m1 \\
\hline 43Tc98 & $(\mathrm{n}, \mathrm{PA})$ & 40Zr94 & 74W181 & $(\mathrm{n}, \mathrm{NA})$ & $72 \mathrm{Hf} 177 \mathrm{~m} 2$ \\
\hline $43 \mathrm{Tc} 99 \mathrm{~m} 1$ & $(\mathrm{n}, \mathrm{P})$ & 42Mo99 & 74W185 & $(\mathrm{n}, \mathrm{N})$ & $74 \mathrm{~W} 185 \mathrm{~m} 1$ \\
\hline 44Ru97 & $(\mathrm{n}, \mathrm{PA})$ & $41 \mathrm{Nb} 93$ & 74W188 & $(\mathrm{n}, \mathrm{NA})$ & $72 \mathrm{Hf} 184 \mathrm{~m} 1$ \\
\hline 44Ru97 & $(\mathrm{n}, \mathrm{PA})$ & $41 \mathrm{Nb} 93 \mathrm{~m} 1$ & 75Re184 & $(\mathrm{n}, \mathrm{N})$ & $75 \operatorname{Re} 184 \mathrm{~m} 1$ \\
\hline $45 \mathrm{Rh} 102$ & $(\mathrm{n}, \mathrm{PA})$ & $42 \mathrm{Mo} 98$ & 76 Os 183 & $(\mathrm{n}, 2 \mathrm{~N} 2 \mathrm{~A})$ & $72 \mathrm{Hfl} 174$ \\
\hline $45 \mathrm{Rh} 102 \mathrm{~m} 1$ & $(\mathrm{n}, \mathrm{PA})$ & 42Mo98 & $76 \mathrm{Os} 183 \mathrm{~m} 1$ & $(\mathrm{n}, 2 \mathrm{~N} 2 \mathrm{~A})$ & $72 \mathrm{Hfl} 174$ \\
\hline 46Pd109 & $(\mathrm{n}, \mathrm{N})$ & 46Pd109m1 & 76 Os193 & $(\mathrm{n}, \mathrm{NA})$ & 74W189 \\
\hline $47 \mathrm{Ag} 105$ & $(\mathrm{n}, \mathrm{PA})$ & 44Ru101 & 77Ir186 & $(\mathrm{n}, 2 \mathrm{~N} 2 \mathrm{~A})$ & 73Ta177 \\
\hline $48 \mathrm{Cd} 107$ & $(\mathrm{n}, \mathrm{PA})$ & 45Rh103 & 77IIr188 & $(\mathrm{n}, 2 \mathrm{~N} 2 \mathrm{~A})$ & 73Ta179 \\
\hline $48 \mathrm{Cd} 107$ & $(\mathrm{n}, \mathrm{PA})$ & $45 \mathrm{Rh} 103 \mathrm{~m} 1$ & \begin{tabular}{|l|}
$77 \operatorname{Ir} 192$ \\
\end{tabular} & $(n, P)$ & $76 \mathrm{Os} 192 \mathrm{~m} 1$ \\
\hline $48 \mathrm{Cd} 115$ & $(\mathrm{n}, \mathrm{N})$ & $48 \mathrm{Cd} 115 \mathrm{~m} 1$ & 77Ir193m1 & $(n, P)$ & $76 \mathrm{Os} 193$ \\
\hline 49In111 & $(\mathrm{n}, \mathrm{N})$ & 49In111m1 & \begin{tabular}{|l|} 
77Ir194 \\
\end{tabular} & $(\mathrm{n}, \mathrm{N})$ & 77Ir $194 \mathrm{~m} 2$ \\
\hline $50 \mathrm{Sn} 117 \mathrm{~m} 1$ & $(n, P)$ & $49 \operatorname{In} 117$ & 78Pt191 & $(\mathrm{n}, 2 \mathrm{~N} 2 \mathrm{~A})$ & $74 \mathrm{~W} 182$ \\
\hline $50 \mathrm{Sn} 117 \mathrm{~m} 1$ & $(n, P)$ & 49In117m1 & 78Pt191 & $(n, P)$ & 77Ir191m1 \\
\hline $51 \mathrm{Sb} 127$ & $(\mathrm{n}, \mathrm{A})$ & $49 \operatorname{In} 124$ & 78Pt191 & $(n, P)$ & 77Ir $191 \mathrm{~m} 2$ \\
\hline $51 \mathrm{Sb} 127$ & $(\mathrm{n}, \mathrm{A})$ & 49In124m1 & 78Pt192 & $(n, P)$ & 77Ir192 \\
\hline $51 \mathrm{Sb} 128$ & $(n, P)$ & $50 \mathrm{Sn} 128 \mathrm{~m} 1$ & \begin{tabular}{|l|}
$78 \mathrm{Pt} 192$ \\
\end{tabular} & $(\mathrm{n}, \mathrm{P})$ & 77Ir $192 \mathrm{~m} 1$ \\
\hline $52 \mathrm{Te} 119$ & $(\mathrm{n}, \mathrm{N})$ & $52 \mathrm{Te} 119 \mathrm{~m} 1$ & 78Pt192 & $(n, P)$ & 77Ir $192 \mathrm{~m} 2$ \\
\hline $52 \mathrm{Te} 121$ & $(\mathrm{n}, \mathrm{NA})$ & $50 \mathrm{Sn} 117$ & 78Pt194 & $(\mathrm{n}, \mathrm{NA})$ & $76 \mathrm{Os} 190 \mathrm{~m} 1$ \\
\hline $52 \mathrm{Te} 121$ & $(\mathrm{n}, \mathrm{NA})$ & $50 \mathrm{Sn} 117 \mathrm{~m} 1$ & 78Pt195 & $(n, P)$ & 77Ir195 \\
\hline $52 \mathrm{Te} 121$ & $(\mathrm{n}, \mathrm{N})$ & $52 \mathrm{Te} 121 \mathrm{~m} 1$ & 78Pt195 & $(\mathrm{n}, \mathrm{P})$ & 77Ir $195 \mathrm{~m} 1$ \\
\hline $52 \mathrm{Te} 121 \mathrm{~m} 1$ & $(\mathrm{n}, \mathrm{NA})$ & $50 \mathrm{Sn} 117$ & 78Pt195 & $(\mathrm{n}, \mathrm{N})$ & 78Pt195m1 \\
\hline $52 \mathrm{Te} 121 \mathrm{~m} 1$ & $(\mathrm{n}, \mathrm{NA})$ & $50 \mathrm{Sn} 117 \mathrm{~m} 1$ & 78Pt195m1 & $(\mathrm{n}, \mathrm{P})$ & 77Ir $195 \mathrm{~m} 1$ \\
\hline $52 \mathrm{Te} 127$ & $(\mathrm{n}, \mathrm{P})$ & $51 \mathrm{Sb} 127$ & 78Pt197 & $(\mathrm{n}, \mathrm{N})$ & 78Pt197m1 \\
\hline $53 \mathrm{II} 23$ & $(\mathrm{n}, \mathrm{NA})$ & $51 \mathrm{Sb} 119$ & \begin{tabular}{|l|}
$78 \mathrm{Pt} 200$ \\
\end{tabular} & $(\mathrm{n}, \mathrm{NA})$ & 76 Os196 \\
\hline $53 \mathrm{I} 123$ & $(\mathrm{n}, \mathrm{NA})$ & $51 \mathrm{Sb} 119 \mathrm{~m} 1$ & $78 \mathrm{Pt} 202$ & $(\mathrm{n}, \mathrm{NA})$ & 76 Os198 \\
\hline
\end{tabular}




\begin{tabular}{|c|c|c|c|c|c|}
\hline Target Nucl. & Reactions & $\begin{array}{l}\text { Product } \\
\text { Nucl. }\end{array}$ & Target Nucl. & Reactions & $\begin{array}{l}\text { Product } \\
\text { Nucl. }\end{array}$ \\
\hline $54 \mathrm{Xe} 125$ & $(\mathrm{n}, \mathrm{N})$ & $54 \mathrm{Xe} 125 \mathrm{~m} 1$ & 79Au193 & $(\mathrm{n}, \mathrm{N})$ & 79Au193m1 \\
\hline $54 \mathrm{Xe} 127$ & $(\mathrm{n}, \mathrm{PA})$ & $51 \mathrm{Sb} 123$ & 79Au194 & $(\mathrm{n}, \mathrm{N})$ & 79Au194m2 \\
\hline $54 \mathrm{Xe} 127$ & $(\mathrm{n}, \mathrm{N})$ & $54 \mathrm{Xe} 127 \mathrm{~m} 1$ & 79Au195 & $(\mathrm{n}, \mathrm{NA})$ & 77Ir191m1 \\
\hline $54 \mathrm{Xe} 133 \mathrm{~m} 1$ & $(\mathrm{n}, \mathrm{P})$ & $53 \mathrm{I} 133$ & 79Au195 & $(\mathrm{n}, \mathrm{NA})$ & 77Ir191m2 \\
\hline $54 \mathrm{Xe} 133 \mathrm{~m} 1$ & $(\mathrm{n}, \mathrm{P})$ & $53 \mathrm{I} 133 \mathrm{~m} 1$ & 79Au195 & $(\mathrm{n}, \mathrm{N})$ & 79Au195m1 \\
\hline $55 \mathrm{Cs} 127$ & $(\mathrm{n}, \mathrm{NA})$ & $53 \mathrm{I} 123$ & 79Au199 & $(\mathrm{n}, \mathrm{P})$ & 78Pt199m1 \\
\hline $55 \mathrm{Cs} 129$ & $(\mathrm{n}, \mathrm{PA})$ & $52 \mathrm{Te} 125 \mathrm{~m} 1$ & $80 \mathrm{Hg} 195$ & $(\mathrm{n}, \mathrm{N})$ & $80 \mathrm{Hg} 195 \mathrm{ml}$ \\
\hline $56 \mathrm{Ba} 128$ & $(\mathrm{n}, \mathrm{N} 2 \mathrm{~A})$ & $52 \mathrm{Te} 120$ & $80 \mathrm{Hg} 195 \mathrm{~m} 1$ & $(\mathrm{n}, 2 \mathrm{~N} 2 \mathrm{~A})$ & 76 Os186 \\
\hline $56 \mathrm{Ba} 128$ & $(\mathrm{n}, \mathrm{NA})$ & $54 \mathrm{Xe} 124$ & $80 \mathrm{Hg} 197$ & $(\mathrm{n}, \mathrm{N})$ & $80 \mathrm{Hg} 197 \mathrm{~m} 1$ \\
\hline $56 \mathrm{Ba} 129$ & $(\mathrm{n}, \mathrm{NA})$ & $54 \mathrm{Xe} 125$ & $80 \mathrm{Hg} 203$ & $(\mathrm{n}, \mathrm{NA})$ & 78Pt199 \\
\hline $56 \mathrm{Ba} 129$ & $(\mathrm{n}, \mathrm{NA})$ & $54 \mathrm{Xe} 125 \mathrm{~m} 1$ & $80 \mathrm{Hg} 203$ & $(\mathrm{n}, \mathrm{NA})$ & 78Pt199m1 \\
\hline $56 \mathrm{Ba} 131$ & $(\mathrm{n}, \mathrm{NA})$ & $54 \mathrm{Xe} 127 \mathrm{~m} 1$ & $81 \mathrm{~T} 1203$ & $(\mathrm{n}, \mathrm{PA})$ & 78Pt199m1 \\
\hline 56Ba131 & $(\mathrm{n}, \mathrm{N})$ & $56 \mathrm{Ba} 131 \mathrm{~m} 1$ & $81 \mathrm{~T} 1204$ & $(\mathrm{n}, \mathrm{NA})$ & 79Au $200 \mathrm{~m} 1$ \\
\hline 56Ba133m1 & $(n, P A)$ & $53 I 129$ & $81 \mathrm{~T} 1205$ & $(\mathrm{n}, \mathrm{P})$ & $80 \mathrm{Hg} 205$ \\
\hline 56Ba135m1 & $(\mathrm{n}, \mathrm{P})$ & $55 \mathrm{Cs} 135 \mathrm{~m} 1$ & $82 \mathrm{~Pb} 203$ & $(\mathrm{n}, \mathrm{N})$ & $82 \mathrm{~Pb} 203 \mathrm{~m} 1$ \\
\hline $56 \mathrm{Ba} 139$ & $(\mathrm{n}, \mathrm{NA})$ & $54 \mathrm{Xe} 135 \mathrm{~m} 1$ & $82 \mathrm{~Pb} 203$ & $(\mathrm{n}, \mathrm{N})$ & $82 \mathrm{~Pb} 203 \mathrm{~m} 2$ \\
\hline $58 \mathrm{Ce} 134$ & $(\mathrm{n}, \mathrm{N} 2 \mathrm{~A})$ & $54 \mathrm{Xe} 126$ & 83Bi205 & $(\mathrm{n}, \mathrm{TA})$ & $80 \mathrm{Hg} 199 \mathrm{~m} 1$ \\
\hline $58 \mathrm{Ce} 135$ & $(\mathrm{n}, \mathrm{NA})$ & 56Ba131 & 83Bi208 & $(\mathrm{n}, \mathrm{TA})$ & $80 \mathrm{Hg} 202$ \\
\hline $58 \mathrm{Ce} 135$ & $(\mathrm{n}, \mathrm{NA})$ & $56 \mathrm{Ba} 131 \mathrm{~m} 1$ & $83 \mathrm{Bi} 210$ & $(\mathrm{n}, \mathrm{N})$ & $83 \mathrm{Bi} 210 \mathrm{~m} 1$ \\
\hline $58 \mathrm{Ce} 135$ & $(n, N)$ & $58 \mathrm{Ce} 135 \mathrm{~m} 1$ & $84 \mathrm{Po} 206$ & $(\mathrm{n}, 2 \mathrm{P})$ & $82 \mathrm{~Pb} 205$ \\
\hline $58 \mathrm{Ce} 137 \mathrm{~m} 1$ & $(\mathrm{n}, \mathrm{NA})$ & $56 \mathrm{Ba} 133$ & 84Po206 & $(\mathrm{n}, 2 \mathrm{P})$ & $82 \mathrm{~Pb} 205 \mathrm{~m} 1$ \\
\hline $58 \mathrm{Ce} 137 \mathrm{~m} 1$ & $(\mathrm{n}, \mathrm{NA})$ & $56 \mathrm{Ba} 133 \mathrm{~m} 1$ & $84 \mathrm{Po} 210$ & $(n, P)$ & $83 \mathrm{Bi} 210$ \\
\hline $60 \mathrm{Nd} 140$ & $(\mathrm{n}, \mathrm{N} 2 \mathrm{~A})$ & $56 \mathrm{Ba} 132$ & $84 \mathrm{Po} 210$ & $(\mathrm{n}, \mathrm{P})$ & 83Bi210m1 \\
\hline $60 \mathrm{Nd} 140$ & $(\mathrm{n}, \mathrm{NA})$ & $58 \mathrm{Ce} 136$ & $85 \mathrm{At} 210$ & $(\mathrm{n}, 2 \mathrm{P})$ & 83Bi209 \\
\hline $60 \mathrm{Nd} 141$ & $(\mathrm{n}, \mathrm{NA})$ & $58 \mathrm{Ce} 137 \mathrm{~m} 1$ & 88Ra228 & $(\mathrm{n}, 3 \mathrm{~N} 2 \mathrm{~A})$ & $84 \mathrm{Po} 218$ \\
\hline $60 \mathrm{Nd} 141$ & $(\mathrm{n}, \mathrm{N})$ & $60 \mathrm{Nd} 141 \mathrm{~m} 1$ & 88Ra228 & $(\mathrm{n}, \mathrm{TA})$ & $85 \mathrm{At} 222$ \\
\hline $61 \mathrm{Pm} 143$ & $(\mathrm{n}, \mathrm{NA})$ & $59 \operatorname{Pr} 139$ & 89Ac228 & $(\mathrm{n}, 3 \mathrm{~N} 2 \mathrm{~A})$ & $85 \mathrm{At} 218$ \\
\hline $61 \mathrm{Pm} 144$ & $(\mathrm{n}, \mathrm{N} 2 \mathrm{~A})$ & 57La136 & 91Pa234 & $(\mathrm{n}, 2 \mathrm{NA})$ & 89Ac229 \\
\hline $61 \mathrm{Pm} 144$ & $(\mathrm{n}, \mathrm{N} 2 \mathrm{~A})$ & 57La136m1 & $93 \mathrm{~Np} 236 \mathrm{~m} 1$ & $(\mathrm{n}, 2 \mathrm{NA})$ & $91 \mathrm{~Pa} 231$ \\
\hline $62 \mathrm{Sm} 146$ & $(n, P)$ & $61 \mathrm{Pm} 146$ & 94Pu234 & $(\mathrm{n}, 3 \mathrm{~N} 2 \mathrm{~A})$ & 90Th224 \\
\hline $63 \mathrm{Eu} 147$ & $(\mathrm{n}, 3 \mathrm{HEA})$ & $59 \operatorname{Pr} 141$ & 94Pu247 & $(\mathrm{n}, 2 \mathrm{NA})$ & 92U242 \\
\hline $64 \mathrm{Gd} 146$ & (n,3HEA) & $60 \mathrm{Nd} 140$ & & & \\
\hline
\end{tabular}




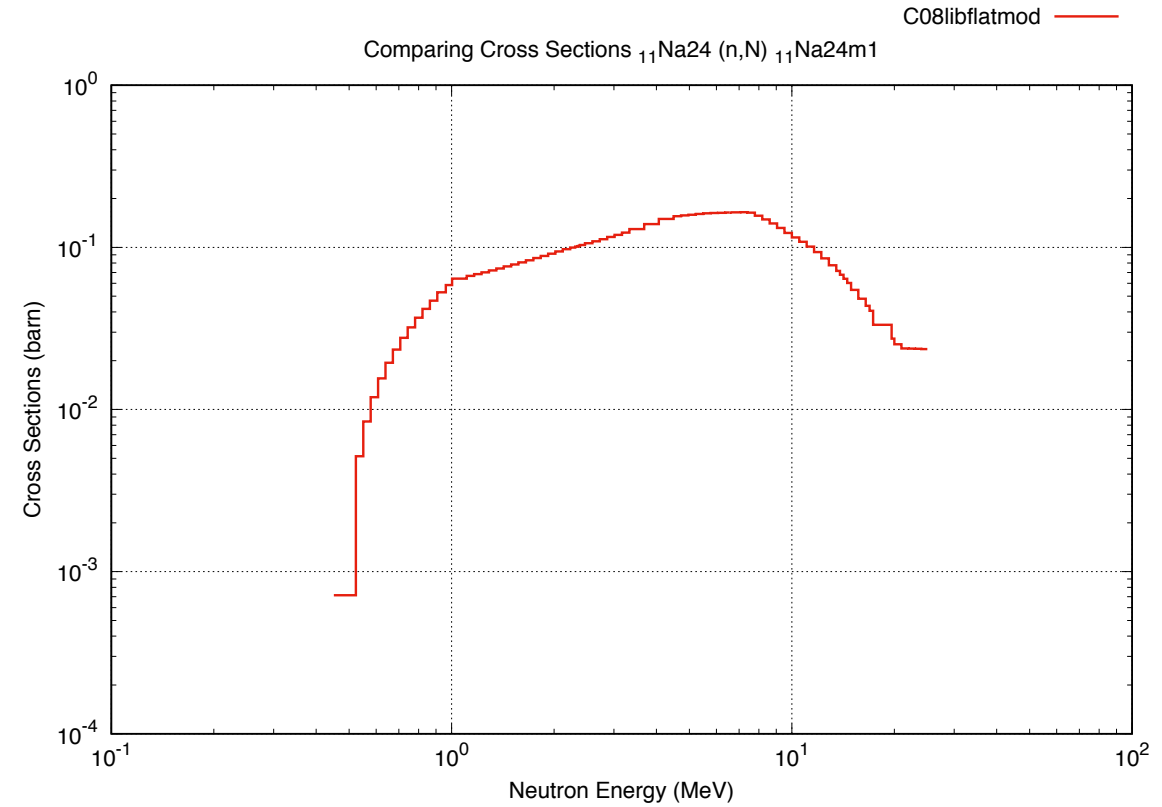

(a)

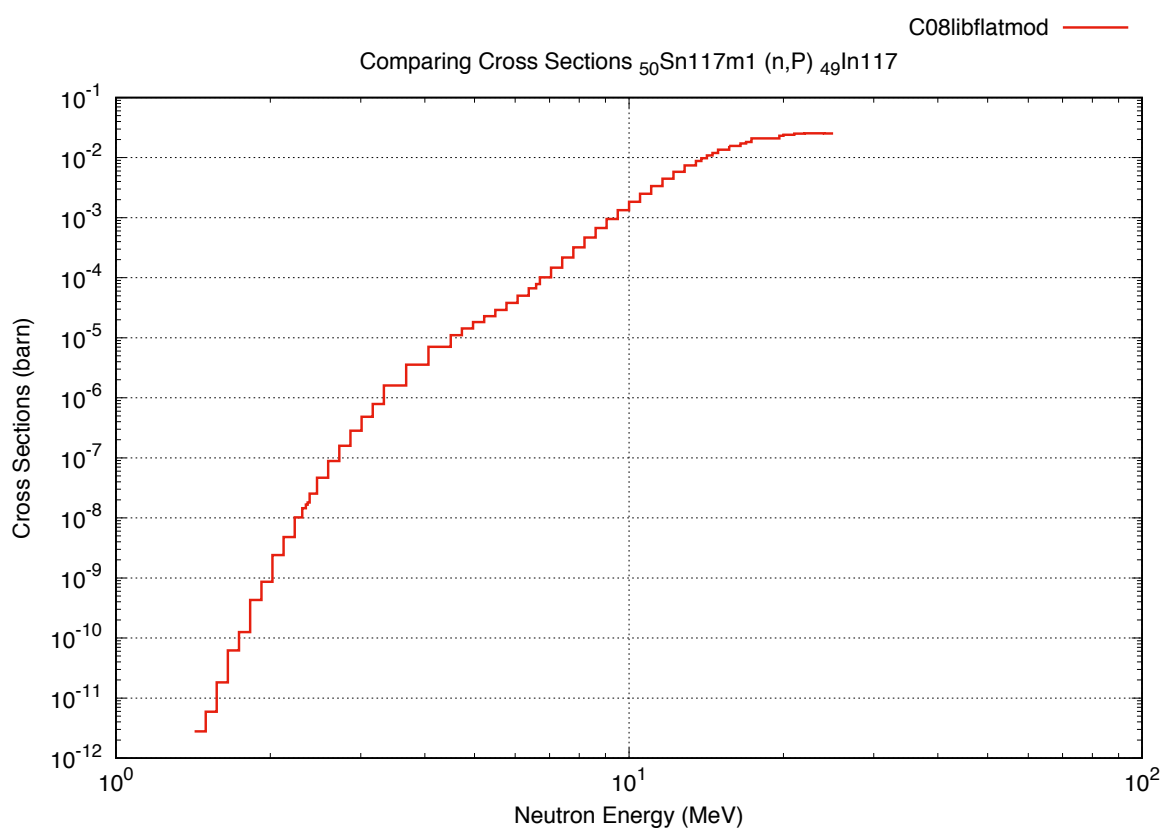

(b) 


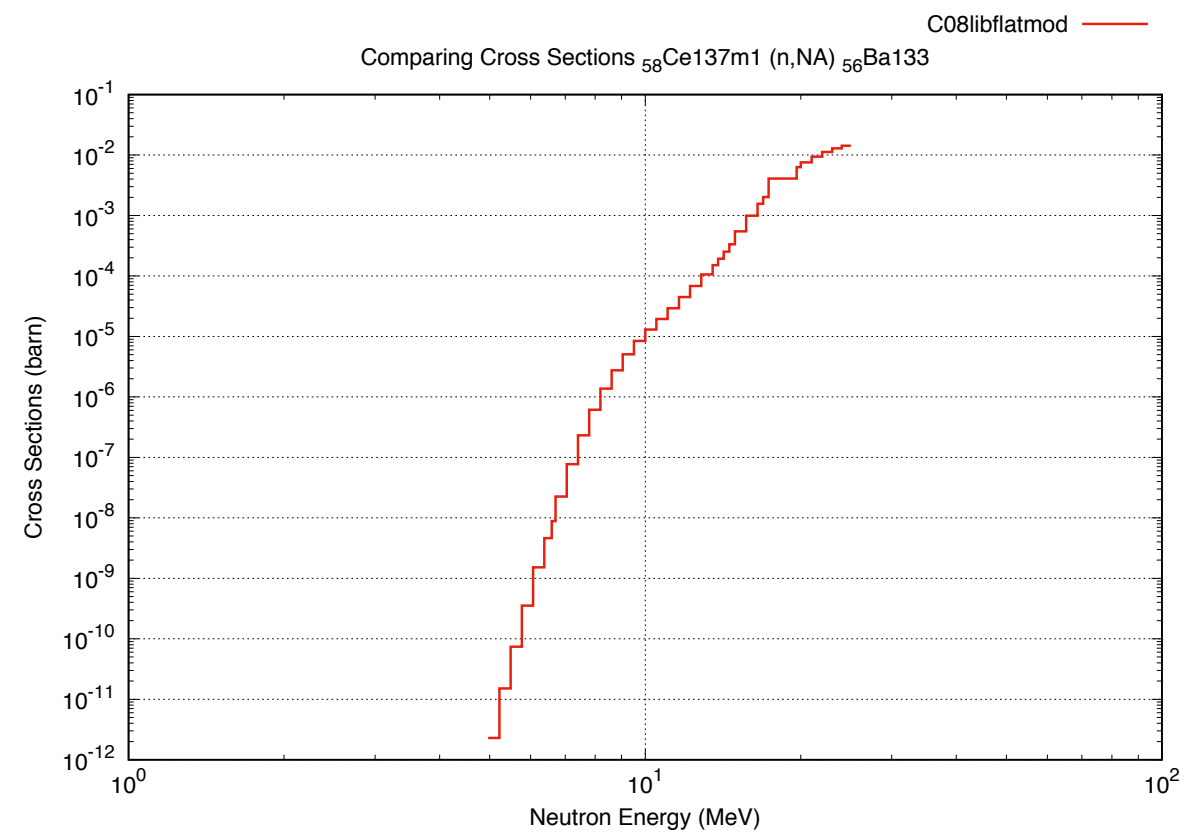

(c)

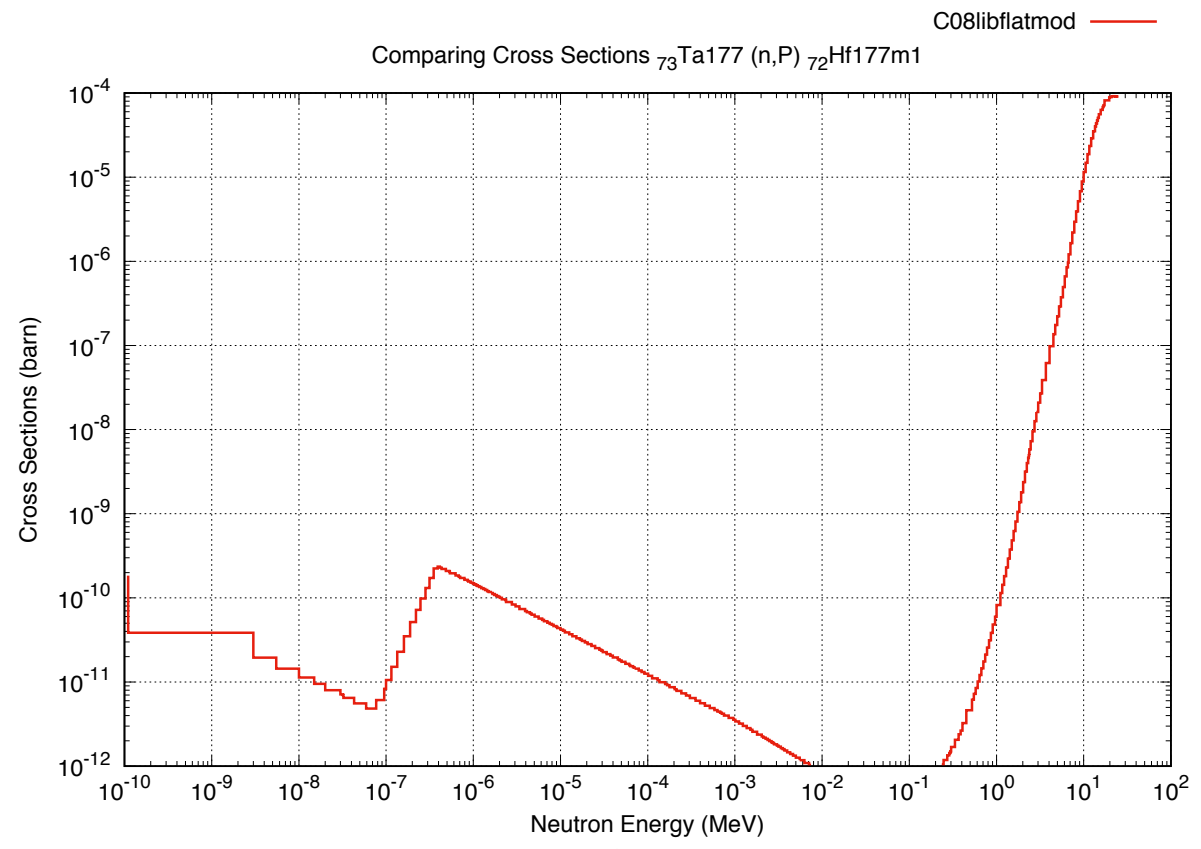

(d) 


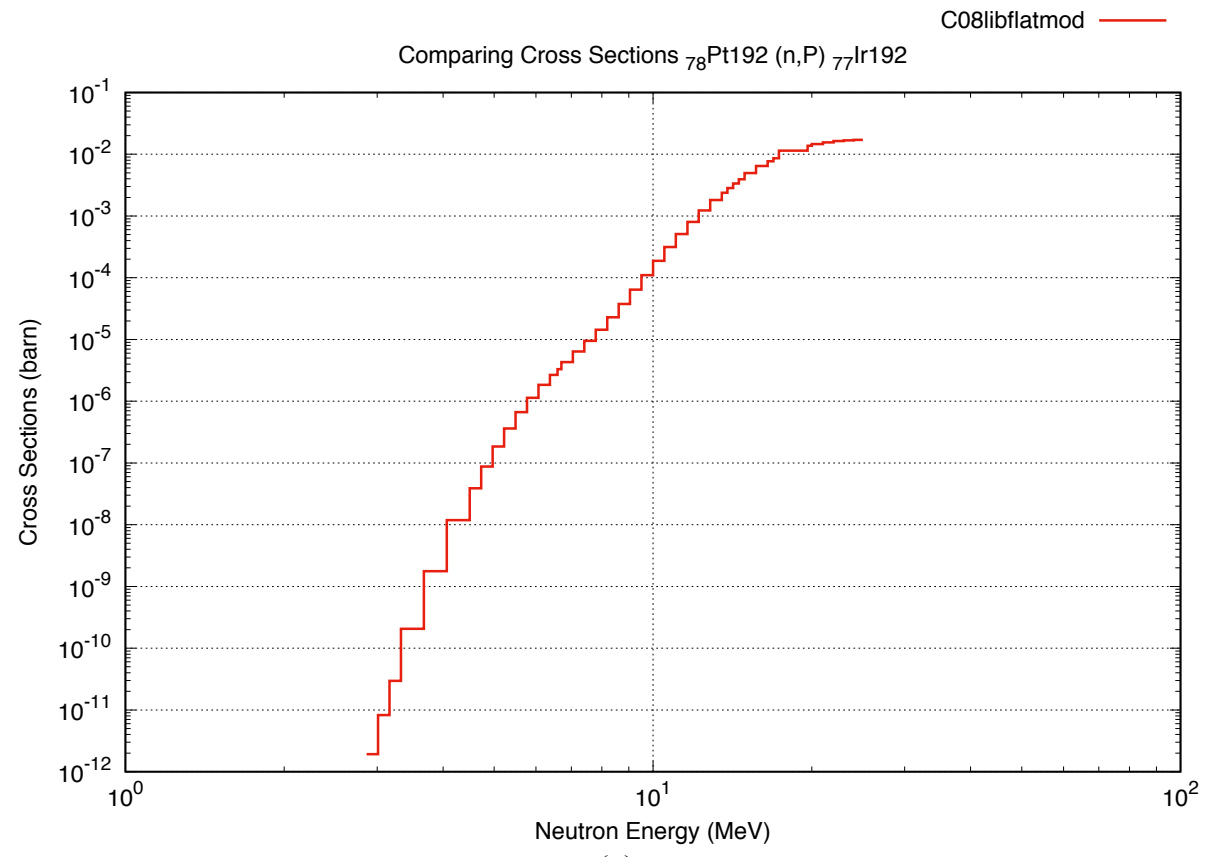

(e)

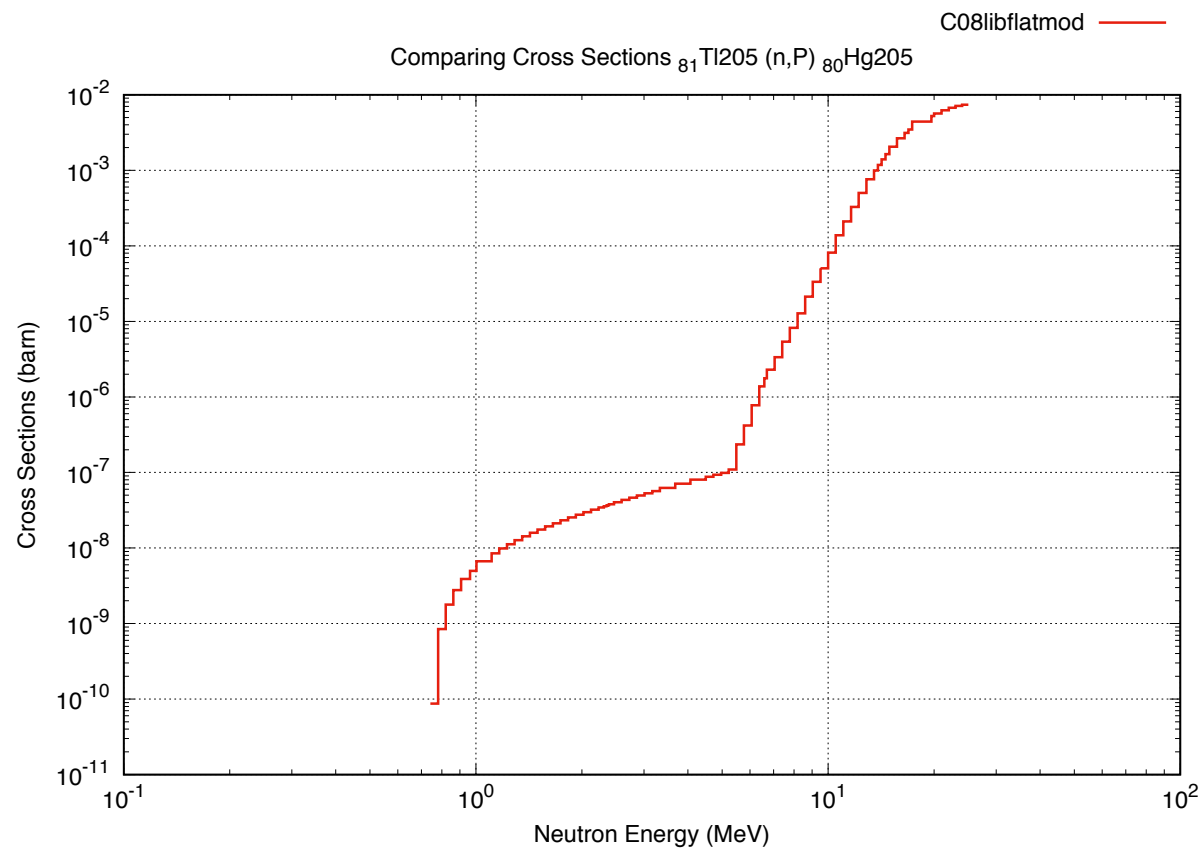

(f)

Figure 8. Examples of reaction cross sections wrongly missing in the current CINDER2008 flat-weighted library but present in updated CINDER2008 flat-weighted library. 


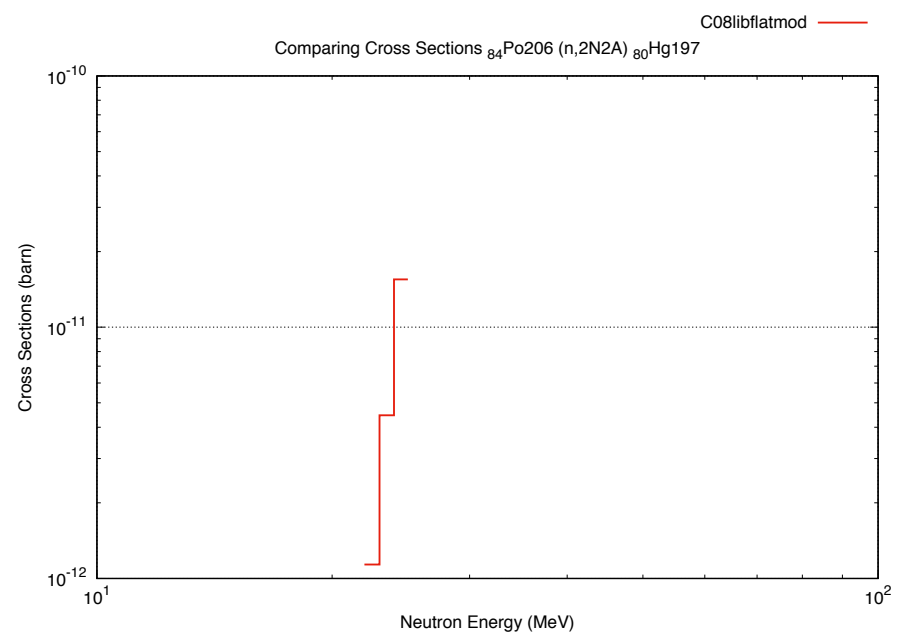

(a)

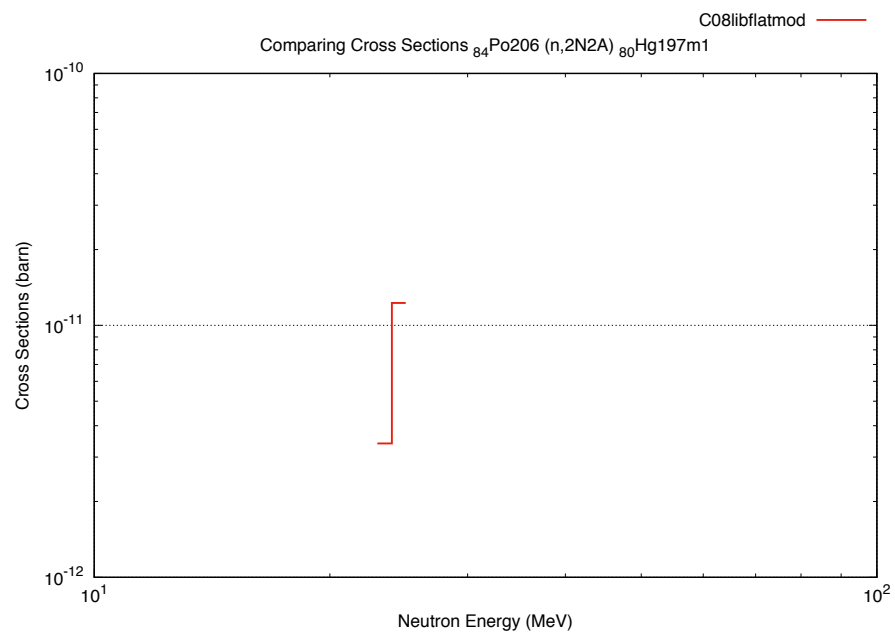

(b)

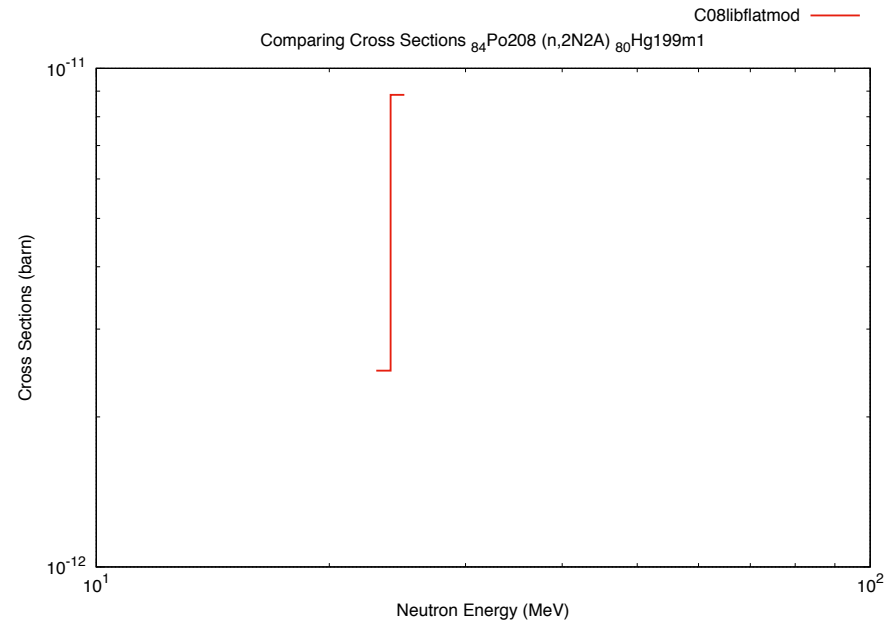

(c)

Figure 9. Three reactions with insignificant cross sections not in the current CINDER2008 flat-weighted library but present in the updated CINDER2008 flat-weighted library. 
Unlike the fission-weighted library case, there are significant differences between the current and updated flat-weighted libraries for many (2862) reaction cross sections. The majority of them, 2787 reactions, are actually due to the truncating issue of the library maker tool as mentioned above. The full list of the 2787 reactions could be found in Appendix A and a few of those cases are illustrated in Fig. 10. It is obvious that those reaction cross sections in the current CINDER2008 flat-weighted library are truncated below 10 $\mathrm{MeV}$. In contrast, the updated flat-weighted library shows the full range of the cross sections down to the lowest energy group $(1 \mathrm{E}-11-1.1 \mathrm{E}-10 \mathrm{MeV})$ and fixes the truncation.

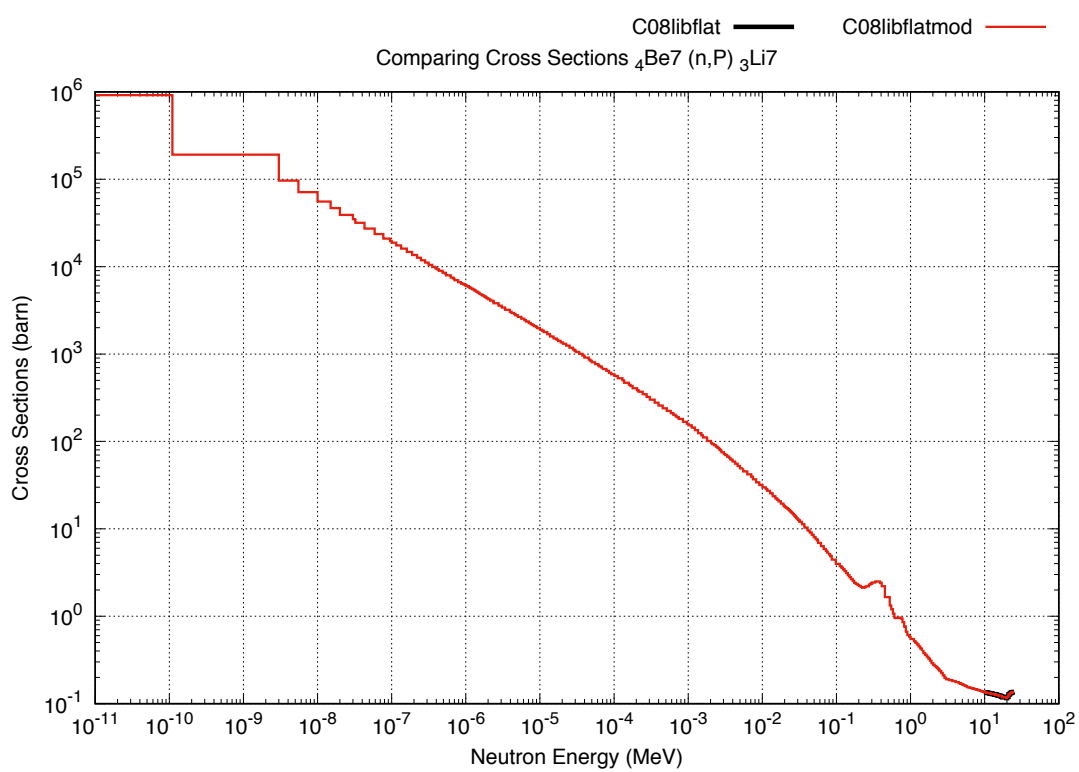

(a)

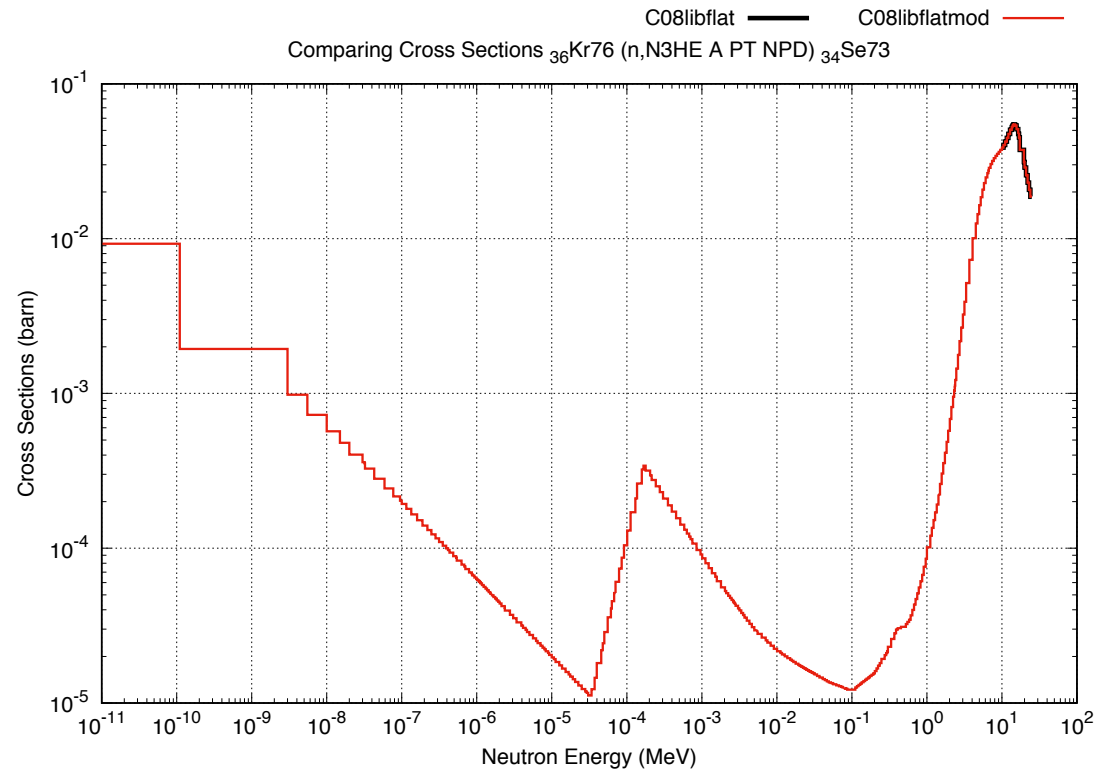

(b) 


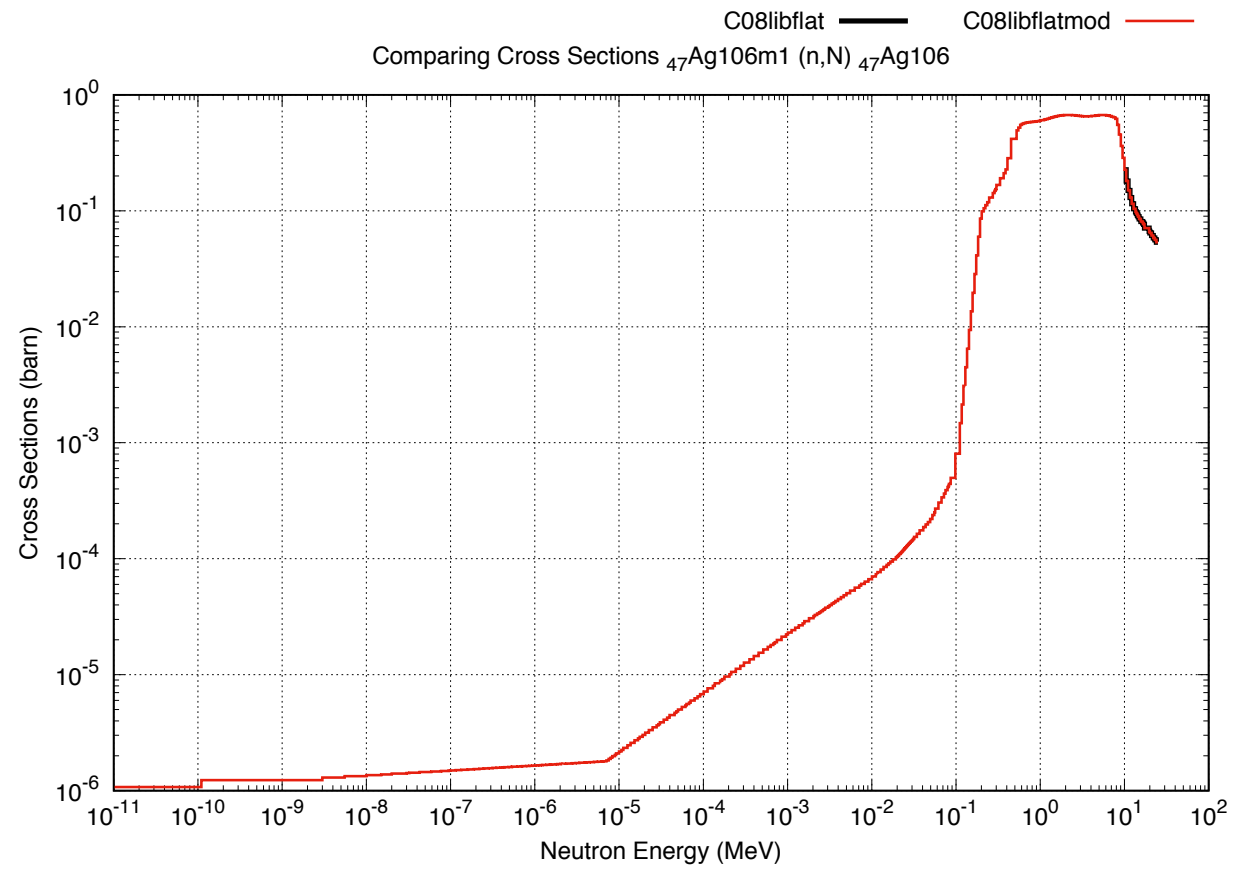

(c)

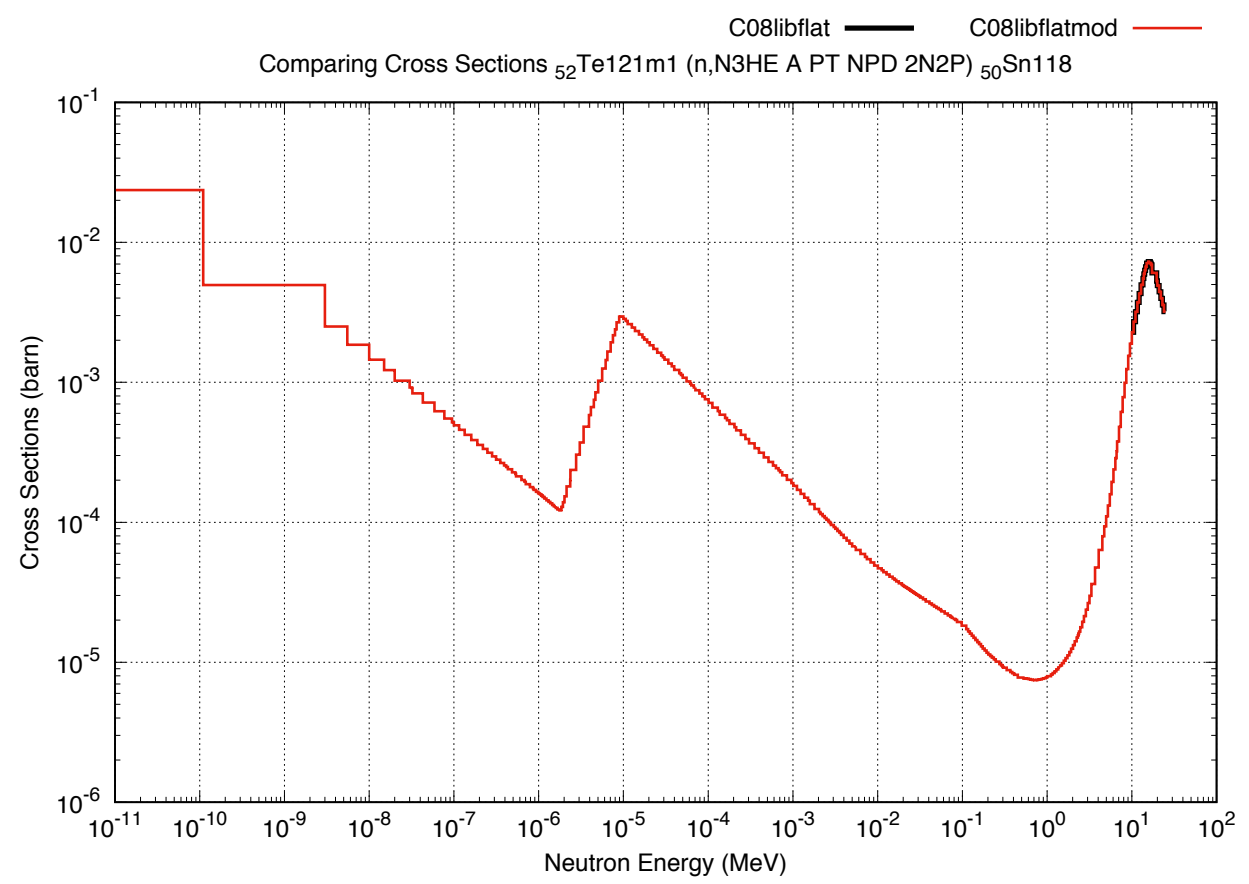

(d) 


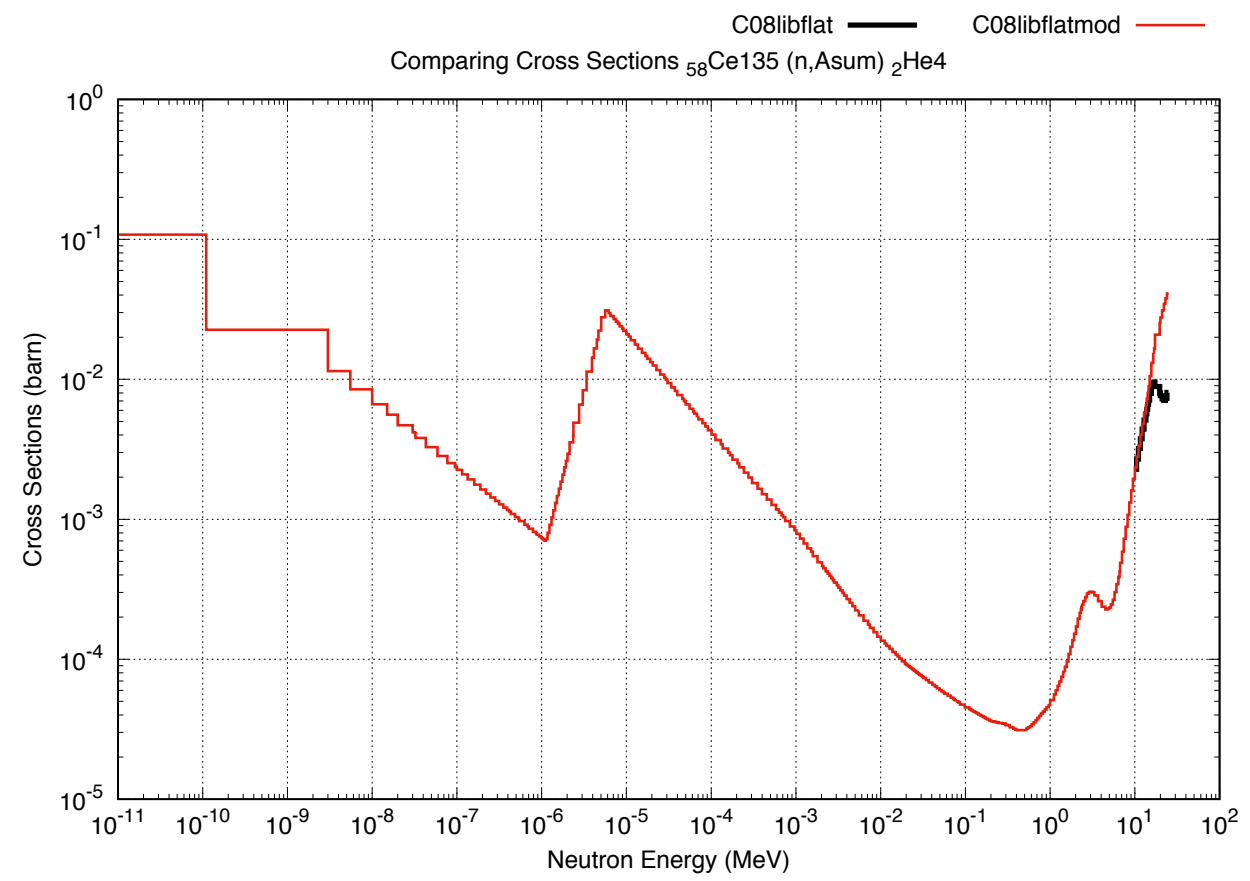

(e)

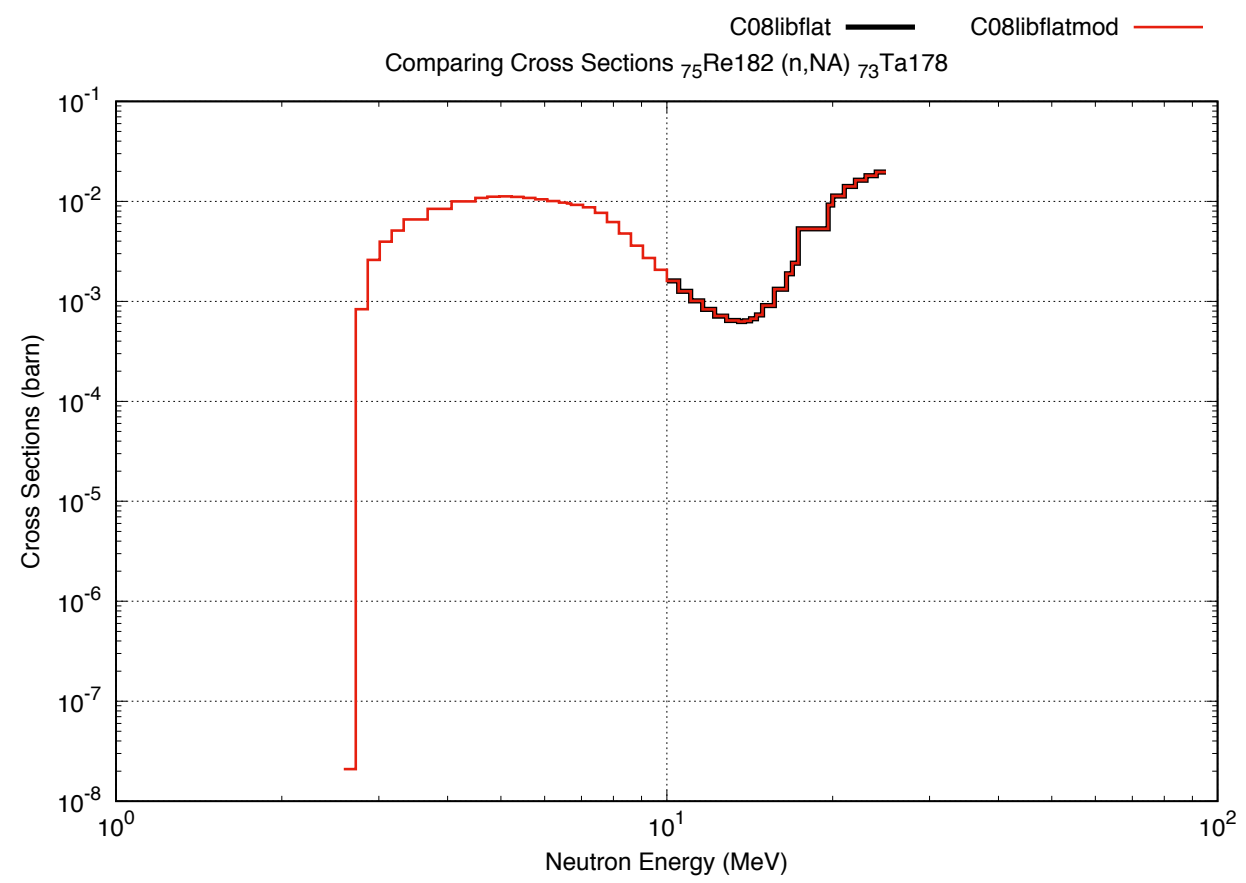

(f)

Figure 10. Examples of reaction cross sections truncated below $10 \mathrm{MeV}$ in the current CINDER2008 flat-weighted library but fixed in the updated CINDER2008 flat-weighted library.

For most of the remaining 75 reaction cross sections, the difference between the current and updated CINDER2008 flat-weighted libraries is just limited to one or two energy groups. Therefore, they do not require further examination. However, for reaction cross sections shown in Fig. 11 whose difference 
between the current and updated CINDER2008 flat-weighted libraries extends to the whole spectrum, a closer investigation may be necessary.

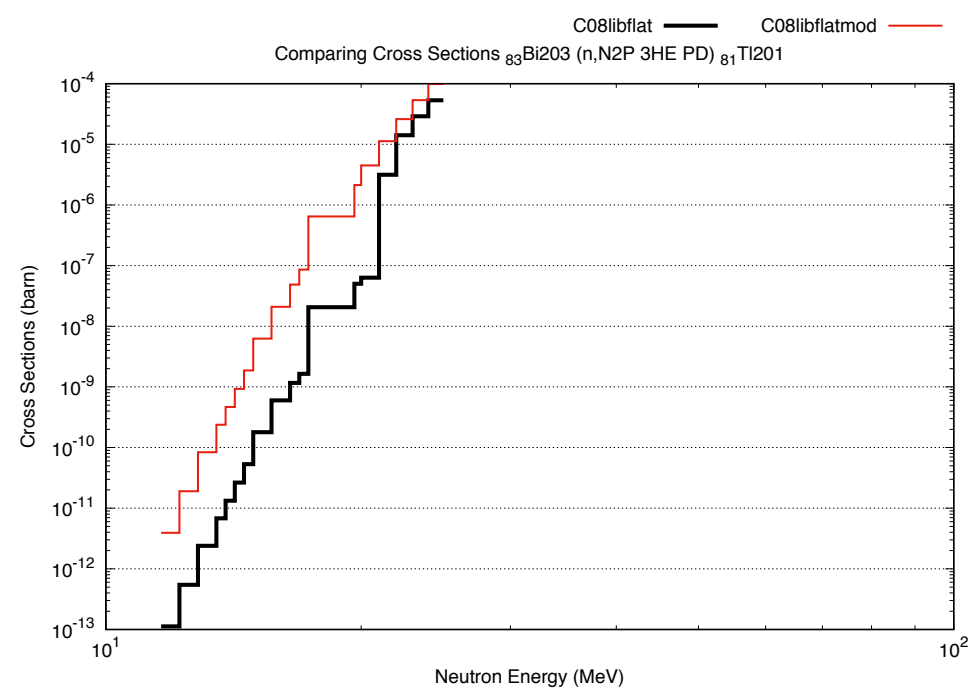

(a)

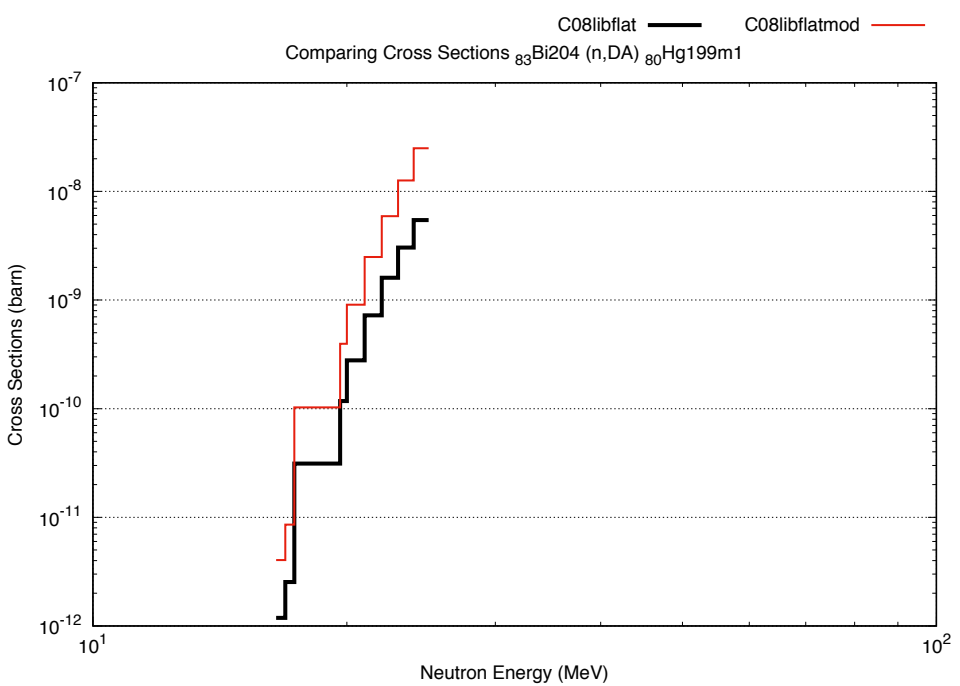

(b) 


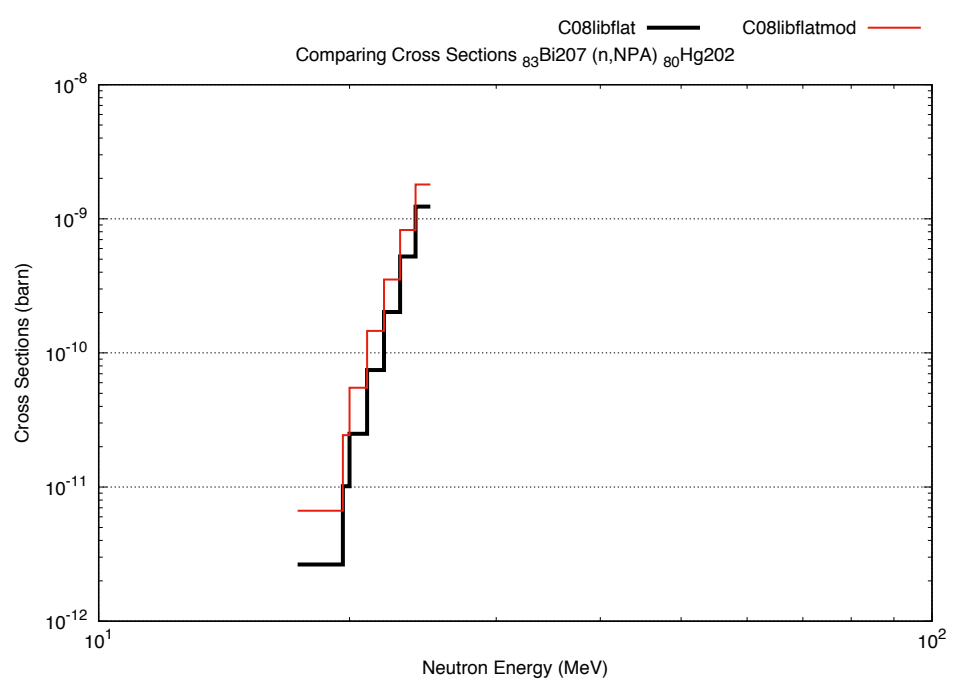

(c)

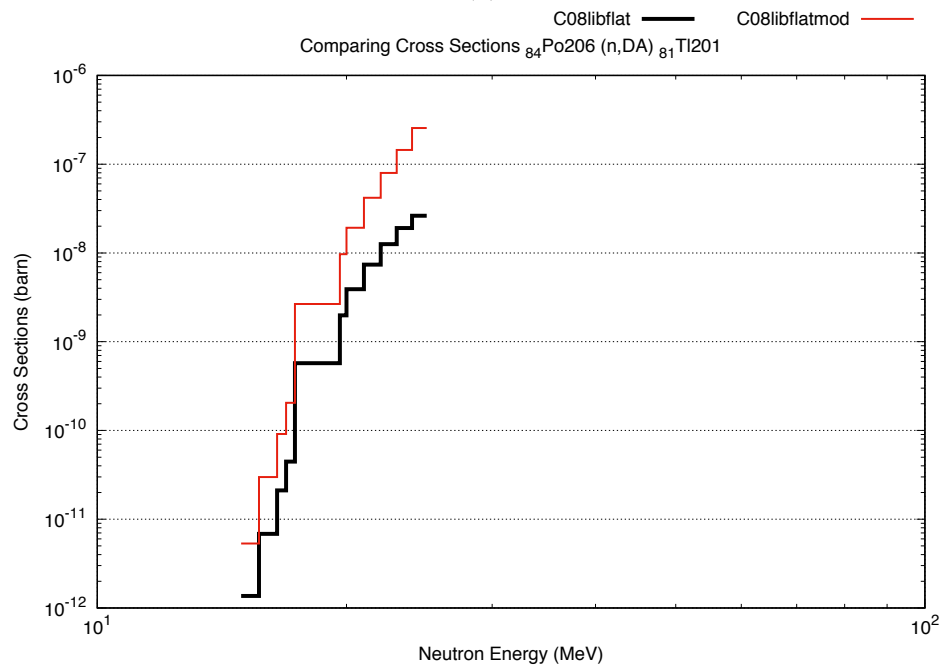

(d)

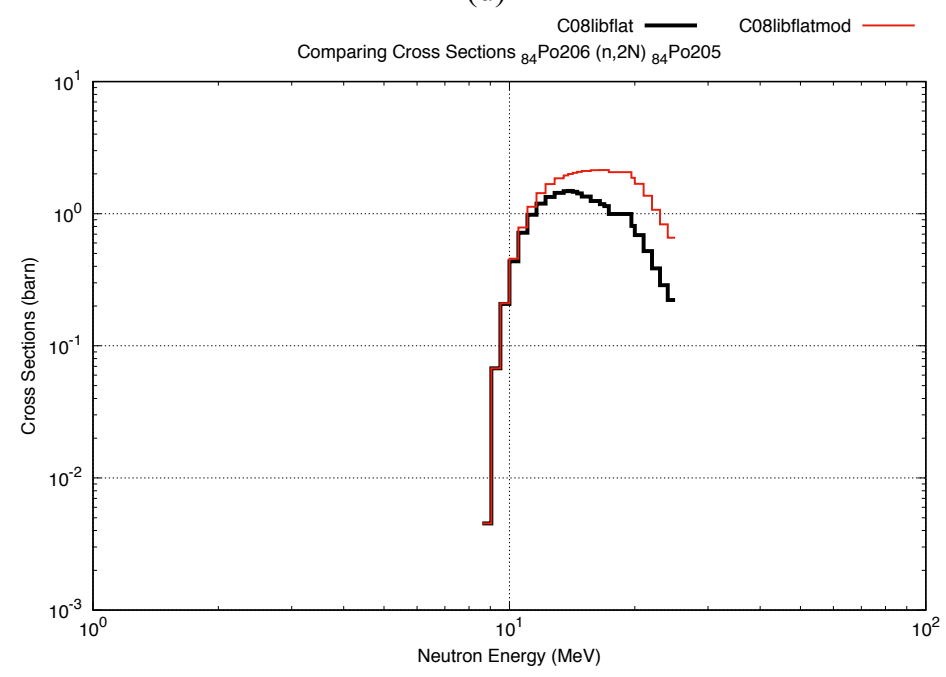

(e)

Figure 11. Reaction cross sections with significant difference between the current and updated CINDER2008 flatweighted libraries, which my require further examination. 


\subsection{FUSION-WEIGHTED LIBRARY}

The fusion-weighted library in CINDER2008 has a significantly different energy binning than those in the fission- and flat-weighted libraries. Particularly, the lowest energy group of the fusion spectrum spans four orders of magnitude $(1 \mathrm{E}-11-1 \mathrm{E}-7 \mathrm{MeV})$. For the purpose of illustration, the plots in this section for reaction cross sections covering the complete fusion spectrum stop at $1 \mathrm{E}-8 \mathrm{MeV}$. However, the fusionweighted library in CINDER2008 has the same truncation issues as the flat-weighted library. So the results of the fusion-weighted library is comparable to those of the flat-weighted library in Section 3.2 and are discussed below.

There are 101 reaction cross sections, as listed in Table 8, present in the current CINDER2008 fusionweighted library but not in the updated one. The discussions for each reaction cross section in Table 8 marked $(*),(\dagger),(\dagger)$ or $\left({ }^{* *}\right)$ are the same as those in Section 3.1 and 3.2. The majority (72) of the reaction cross sections are marked $(* *)$, which means that, as discussed in Section 3.2, they are included in EAF2010 but they only involve one or two highest energy groups with insignificant cross sections around 1E12 barn, the cut-off limit of the CINDER2008 library maker tool. Three cases of such reaction cross sections are shown as examples in Fig. 12. Again this is probably due to the treatment of the cut-off limit in the library maker tool.

Table 8. List of 101 reaction cross sections in the current CINDER2008 fusion-weighted library but not in the updated CINDER2008 fusion-weighted library.

\begin{tabular}{|c|c|c|c|c|c|}
\hline Target Nucl. & Reactions & $\begin{array}{l}\text { Product } \\
\text { Nucl. }\end{array}$ & Target Nucl. & Reactions & $\begin{array}{l}\text { Product } \\
\text { Nucl. }\end{array}$ \\
\hline$* 30 \mathrm{Zn} 62$ & $(\mathrm{n}, 2 \mathrm{~N})$ & $30 \mathrm{Zn} 61 \mathrm{~m} 1$ & $* * 53 \mathrm{I} 126$ & $(\mathrm{n}, \mathrm{DA})$ & $50 \mathrm{Sn} 121 \mathrm{~m} 1$ \\
\hline *30Zn62 & $(\mathrm{n}, 2 \mathrm{~N})$ & $30 \mathrm{Zn} 61 \mathrm{~m} 2$ & $* * 53 \mathrm{I} 128$ & $(\mathrm{n}, \mathrm{TA})$ & $50 \mathrm{Sn} 122$ \\
\hline *30Zn62 & $(\mathrm{n}, 2 \mathrm{~N})$ & $30 \mathrm{Zn} 61 \mathrm{~m} 3$ & $* * 54 \mathrm{Xe} 127$ & $(\mathrm{n}, \mathrm{N} 2 \mathrm{~A})$ & $50 \mathrm{Sn} 119$ \\
\hline *52Te129 & $(\mathrm{n}, 2 \mathrm{~N})$ & $52 \mathrm{Te} 128 \mathrm{~m} 1$ & $* * 56 \mathrm{Ba} 131$ & $(\mathrm{n}, \mathrm{N} 2 \mathrm{~A})$ & $52 \mathrm{Te} 123$ \\
\hline *56Ba129 & $\begin{array}{l}(\mathrm{n}, \mathrm{ND} 2 \mathrm{NP} \\
\mathrm{T})\end{array}$ & $55 \mathrm{Cs} 127 \mathrm{~m} 1$ & $* * 56 \mathrm{Ba} 133 \mathrm{~m} 1$ & $(\mathrm{n}, \mathrm{TA})$ & $53 \mathrm{I} 127$ \\
\hline *56Ba129 & $(n, G)$ & $56 \mathrm{Ba} 130 \mathrm{~m} 1$ & $* * 58 \mathrm{Ce} 137$ & $(\mathrm{n}, \mathrm{N} 2 \mathrm{~A})$ & $54 \mathrm{Xe} 129 \mathrm{~m} 1$ \\
\hline *58Ce 134 & $(\mathrm{n}, \mathrm{NA})$ & $56 \mathrm{Ba} 130 \mathrm{~m} 1$ & $* * 58 \mathrm{Ce} 137$ & $(\mathrm{n}, \mathrm{TA})$ & $55 \mathrm{Cs} 131$ \\
\hline$* 58 \mathrm{Ce} 137$ & $(\mathrm{n}, 2 \mathrm{~N})$ & $58 \mathrm{Ce} 136 \mathrm{~m} 1$ & $* * 60 \mathrm{Nd} 140$ & $(\mathrm{n}, \mathrm{NT})$ & $59 \operatorname{Pr} 137$ \\
\hline$* 58 \mathrm{Ce} 137$ & $(\mathrm{n}, \mathrm{G})$ & $58 \mathrm{Ce} 138 \mathrm{~m} 1$ & $* * 60 \mathrm{Nd} 141$ & $(\mathrm{n}, \mathrm{TA})$ & 57La135 \\
\hline *61Pm143 & $(\mathrm{n}, \mathrm{NPA}$ DA $)$ & $58 \mathrm{Ce} 138 \mathrm{~m} 1$ & $* * 65 \mathrm{~Tb} 157$ & $(\mathrm{n}, \mathrm{N} 2 \mathrm{~A})$ & $61 \mathrm{Pm} 149$ \\
\hline *61Pm143 & $(\mathrm{n}, 2 \mathrm{~N})$ & $61 \mathrm{Pm} 142 \mathrm{~m} 1$ & $* * 67 \mathrm{Ho} 163$ & $(\mathrm{n}, \mathrm{NPA})$ & $64 \mathrm{Gd} 158$ \\
\hline *65Tb152 & $(\mathrm{n}, \mathrm{NA})$ & $63 \mathrm{Eu} 148 \mathrm{~m} 1$ & $* * 68 \operatorname{Er} 161$ & $(\mathrm{n}, \mathrm{NPA})$ & $65 \mathrm{~Tb} 156 \mathrm{~m} 1$ \\
\hline *65Tb152 & $(\mathrm{n}, \mathrm{G})$ & $65 \mathrm{~Tb} 153 \mathrm{~m} 1$ & $* * 68 \operatorname{Er} 161$ & $(\mathrm{n}, \mathrm{NPA})$ & $65 \mathrm{~Tb} 156 \mathrm{~m} 2$ \\
\hline *74W181 & $(\mathrm{n}, 2 \mathrm{~N})$ & $74 \mathrm{~W} 180 \mathrm{~m} 1$ & $* * 68 \operatorname{Er} 172$ & $(\mathrm{n}, \mathrm{X} \backslash 3 \mathrm{HE})$ & $2 \mathrm{He} 3$ \\
\hline *79Au198 & $(\mathrm{n}, \mathrm{G})$ & 79Au199m1 & $* * 68 \operatorname{Er} 172$ & $(\mathrm{n}, 3 \mathrm{HE})$ & $66 \mathrm{Dy} 170$ \\
\hline *82Pb202 & $(\mathrm{n}, \mathrm{G})$ & $82 \mathrm{~Pb} 203 \mathrm{~m} 2$ & $* * 69 \mathrm{Tm} 171$ & $(\mathrm{n}, 3 \mathrm{NA})$ & $67 \mathrm{Ho} 165$ \\
\hline *83Bi203 & $(\mathrm{n}, 2 \mathrm{NA})$ & $81 \mathrm{~T} 1198 \mathrm{~m} 2$ & $* * 72 \mathrm{Hf} 170$ & $(\mathrm{n}, \mathrm{TA})$ & $69 \mathrm{Tm} 164$ \\
\hline *83Bi203 & $(\mathrm{n}, \mathrm{NA})$ & $81 \mathrm{~T} 1199 \mathrm{~m} 1$ & $* * 72 \mathrm{Hf} 170$ & $(\mathrm{n}, \mathrm{TA})$ & $69 \operatorname{Tm} 164 \mathrm{~m} 1$ \\
\hline *84Po206 & $(\mathrm{n}, \mathrm{NPA}$ DA) & $81 \mathrm{~T} 1201 \mathrm{~m} 1$ & $* * 72 \mathrm{Hf} 173$ & (n,3NA) & $70 \mathrm{Yb} 167$ \\
\hline
\end{tabular}




\begin{tabular}{|c|c|c|c|c|c|}
\hline Target Nucl. & Reactions & $\begin{array}{l}\text { Product } \\
\text { Nucl. }\end{array}$ & Target Nucl. & Reactions & $\begin{array}{l}\text { Product } \\
\text { Nucl. }\end{array}$ \\
\hline *84Po206 & $(\mathrm{n}, 2 \mathrm{~N})$ & $84 \mathrm{Po} 205 \mathrm{~m} 1$ & $* * 72 \mathrm{Hf} 178 \mathrm{~m} 2$ & $(\mathrm{n}, 2 \mathrm{P})$ & $70 \mathrm{Yb} 177 \mathrm{~m} 1$ \\
\hline *84Po206 & $(\mathrm{n}, 2 \mathrm{~N})$ & $84 \mathrm{Po} 205 \mathrm{~m} 2$ & $* * 73 \mathrm{Ta} 180 \mathrm{~m} 1$ & $(\mathrm{n}, \mathrm{N} 2 \mathrm{~A})$ & $69 \mathrm{Tm} 172$ \\
\hline$* 85$ At 211 & $(\mathrm{n}, 2 \mathrm{~A})$ & $81 \mathrm{~T} 1204 \mathrm{~m} 1$ & $* * 75 \operatorname{Re} 188$ & (n,3NA) & $73 \mathrm{Ta} 182 \mathrm{~m} 1$ \\
\hline *85At211 & $(\mathrm{n}, 2 \mathrm{NA})$ & 83Bi206m1 & $* * 75 \operatorname{Re} 188$ & $(\mathrm{n}, 3 \mathrm{NA})$ & $73 \mathrm{Ta} 182 \mathrm{~m} 2$ \\
\hline *85At211 & $(\mathrm{n}, \mathrm{NA})$ & $83 \mathrm{Bi} 207 \mathrm{~m} 1$ & $* * 76$ Os 185 & $(\mathrm{n}, 3 \mathrm{NA})$ & $74 \mathrm{~W} 179 \mathrm{~m} 1$ \\
\hline$\dagger 28 \mathrm{Ni57}$ & $(\mathrm{n}, 2 \mathrm{NA})$ & $26 \mathrm{Fe} 52$ & $* * 76 \mathrm{Os} 191 \mathrm{~m} 1$ & $(\mathrm{n}, 3 \mathrm{NA})$ & $74 \mathrm{~W} 185 \mathrm{~m} 1$ \\
\hline$\$ 73 \mathrm{Ta} 180$ & $(\mathrm{n}, 3 \mathrm{~N})$ & 73Ta178m1 & $* * 78 \mathrm{Pt} 189$ & $(\mathrm{n}, 2 \mathrm{~N} 2 \mathrm{~A})$ & $74 \mathrm{~W} 180$ \\
\hline$\$ 74 \mathrm{~W} 181$ & $(\mathrm{n}, \mathrm{NT})$ & $73 \mathrm{Ta} 178 \mathrm{~m} 1$ & **78Pt189 & $(\mathrm{n}, 4 \mathrm{NA})$ & $76 \mathrm{Os} 182$ \\
\hline$\$ 82 \mathrm{~Pb} 202$ & $(\mathrm{n}, \mathrm{G})$ & $82 \mathrm{~Pb} 203 \mathrm{~m} 1$ & $* * 78 \mathrm{Pt} 194$ & $(\mathrm{n}, 2 \mathrm{~A})$ & 74W187 \\
\hline$\$ 83 \mathrm{Bi} 203$ & $(\mathrm{n}, 2 \mathrm{NA})$ & $81 \mathrm{~T} 1198 \mathrm{~m} 1$ & $* * 78 \mathrm{Pt} 195$ & $(\mathrm{n}, \mathrm{PA})$ & $75 \operatorname{Re} 191$ \\
\hline$* * 19 \mathrm{~K} 43$ & $(\mathrm{n}, 2 \mathrm{~A})$ & $15 \mathrm{P} 36$ & **78Pt195 & $(\mathrm{n}, 2 \mathrm{P})$ & 76 Os194 \\
\hline$* * 19 \mathrm{~K} 43$ & $(\mathrm{n}, \mathrm{PA})$ & $16 \mathrm{~S} 39$ & **79Au195 & $(\mathrm{n}, 2 \mathrm{P})$ & $77 \operatorname{Ir} 194 \mathrm{~m} 1$ \\
\hline$* * 20 \mathrm{Ca} 45$ & $(\mathrm{n}, \mathrm{PA})$ & $17 \mathrm{Cl} 41$ & **79Au195 & $(\mathrm{n}, 2 \mathrm{P})$ & $77 \operatorname{Ir} 194 \mathrm{~m} 2$ \\
\hline$* * 21 \mathrm{Sc} 48$ & $(\mathrm{n}, \mathrm{NT})$ & $20 \mathrm{Ca} 45$ & **79Au196m2 & $(\mathrm{n}, 2 \mathrm{P})$ & 77Ir $195 \mathrm{~m} 1$ \\
\hline$* * 26 \mathrm{Fe} 52$ & $(\mathrm{n}, \mathrm{DA})$ & $23 \mathrm{~V} 47$ & $* * 80 \mathrm{Hg} 193$ & $(\mathrm{n}, 2 \mathrm{~N} 2 \mathrm{~A})$ & $76 \mathrm{Os} 184$ \\
\hline$* * 28 \mathrm{Ni} 57$ & $(\mathrm{n}, \mathrm{DA})$ & $25 \mathrm{Mn} 52 \mathrm{~m} 1$ & $* * 80 \mathrm{Hg} 195$ & $(\mathrm{n}, \mathrm{NPA})$ & 77Ir 190 \\
\hline **28Ni57 & $(\mathrm{n}, \mathrm{P} 3 \mathrm{HE})$ & $25 \mathrm{Mn} 54$ & $* * 80 \mathrm{Hg} 203$ & $(\mathrm{n}, \mathrm{X} \backslash 3 \mathrm{HE})$ & $2 \mathrm{He} 3$ \\
\hline **33As71 & $(n, 3 P)$ & $30 \mathrm{Zn} 69$ & $* * 80 \mathrm{Hg} 203$ & $(\mathrm{n}, 3 \mathrm{HE})$ & $78 \mathrm{Pt} 201$ \\
\hline **33As 77 & $(\mathrm{n}, 2 \mathrm{NA})$ & $31 \mathrm{Ga} 72 \mathrm{~m} 1$ & $* * 81$ T1199 & $(\mathrm{n}, \mathrm{NPA})$ & 78Pt194 \\
\hline$* * 43 \mathrm{Tc} 95$ & $(\mathrm{n}, \mathrm{TA})$ & $40 \mathrm{Zr} 89$ & $* * 81 \mathrm{~T} 1201$ & $(\mathrm{n}, 2 \mathrm{P})$ & 79Au200m1 \\
\hline$* * 43 \mathrm{Tc} 96$ & $(\mathrm{n}, \mathrm{N} 2 \mathrm{~A})$ & $39 Y 88$ & $* * 82 \mathrm{~Pb} 200$ & $(\mathrm{n}, \mathrm{NPA})$ & 79Au195m1 \\
\hline$* * 46 \operatorname{Pd} 112$ & $(n, X \backslash 3 \mathrm{HE})$ & $2 \mathrm{He} 3$ & **82Pb209 & $(\mathrm{n}, \mathrm{X} \backslash 3 \mathrm{HE})$ & $2 \mathrm{He} 3$ \\
\hline$* * 46 \mathrm{Pd} 112$ & $(\mathrm{n}, 3 \mathrm{HE})$ & $44 \mathrm{Ru} 110$ & $* * 82 \mathrm{~Pb} 209$ & $(\mathrm{n}, 3 \mathrm{HE})$ & $80 \mathrm{Hg} 207$ \\
\hline$* * 49 \operatorname{In} 111$ & $(\mathrm{n}, \mathrm{N} 2 \mathrm{~A})$ & $45 \mathrm{Rh} 103$ & **83Bi203 & $(\mathrm{n}, \mathrm{A})$ & $81 \mathrm{~T} 1200 \mathrm{~m} 1$ \\
\hline$* * 50 \mathrm{Sn} 119 \mathrm{~m} 1$ & $(\mathrm{n}, \mathrm{PA})$ & $47 \mathrm{Ag} 115 \mathrm{~m} 1$ & **83Bi203 & $(\mathrm{n}, 3 \mathrm{HE})$ & $81 \mathrm{~T} 1201 \mathrm{~m} 1$ \\
\hline **50Sn119m1 & $(\mathrm{n}, \mathrm{NT})$ & 49In116m1 & **83Bi205 & $(\mathrm{n}, \mathrm{TA})$ & $80 \mathrm{Hg} 199 \mathrm{ml}$ \\
\hline$* * 50 \mathrm{Sn} 119 \mathrm{~m} 1$ & $(\mathrm{n}, \mathrm{NT})$ & $49 \operatorname{In} 116 \mathrm{~m} 2$ & $* * 83 \mathrm{Bi} 207$ & $(\mathrm{n}, \mathrm{TA})$ & $80 \mathrm{Hg} 201$ \\
\hline$* * 50 \operatorname{Sn} 121$ & $(\mathrm{n}, 2 \mathrm{P})$ & $48 \mathrm{Cd} 120$ & $* * 83 \mathrm{Bi} 210$ & $(\mathrm{n}, \mathrm{NPA})$ & $80 \mathrm{Hg} 205$ \\
\hline$* * 50 \operatorname{Sn} 121$ & $(\mathrm{n}, \mathrm{NT})$ & $49 \operatorname{In} 118$ & $* * 91 \mathrm{~Pa} 228$ & $(\mathrm{n}, 2 \mathrm{NT})$ & $90 \mathrm{Th} 224$ \\
\hline **50Sn $121 \mathrm{~m} 1$ & $(\mathrm{n}, \mathrm{NT})$ & 49In118 & $* * 100 \mathrm{Fm} 252$ & $(\mathrm{n}, 3 \mathrm{~N} 2 \mathrm{~A})$ & $96 \mathrm{Cm} 242$ \\
\hline$* * 52 \mathrm{Te} 121 \mathrm{~m} 1$ & $(\mathrm{n}, \mathrm{TA})$ & 49In115 & $* * 100 \mathrm{Fm} 257$ & $(\mathrm{n}, \mathrm{N} 2 \mathrm{~A})$ & $96 \mathrm{Cm} 249$ \\
\hline **52Te129 & $(\mathrm{n}, 2 \mathrm{P})$ & $50 \mathrm{Sn} 128 \mathrm{~m} 1$ & & & \\
\hline
\end{tabular}




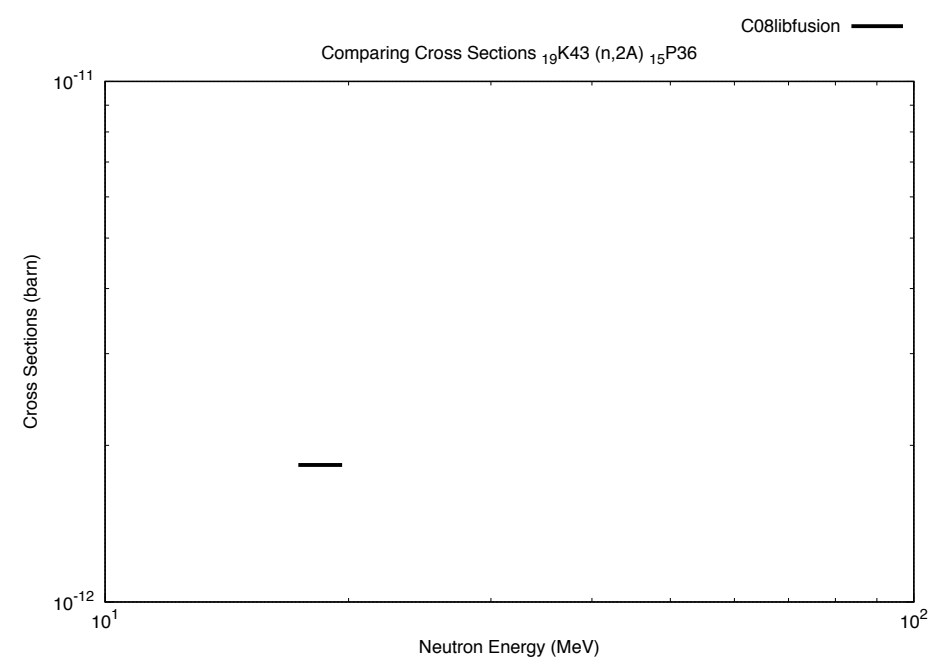

(a)

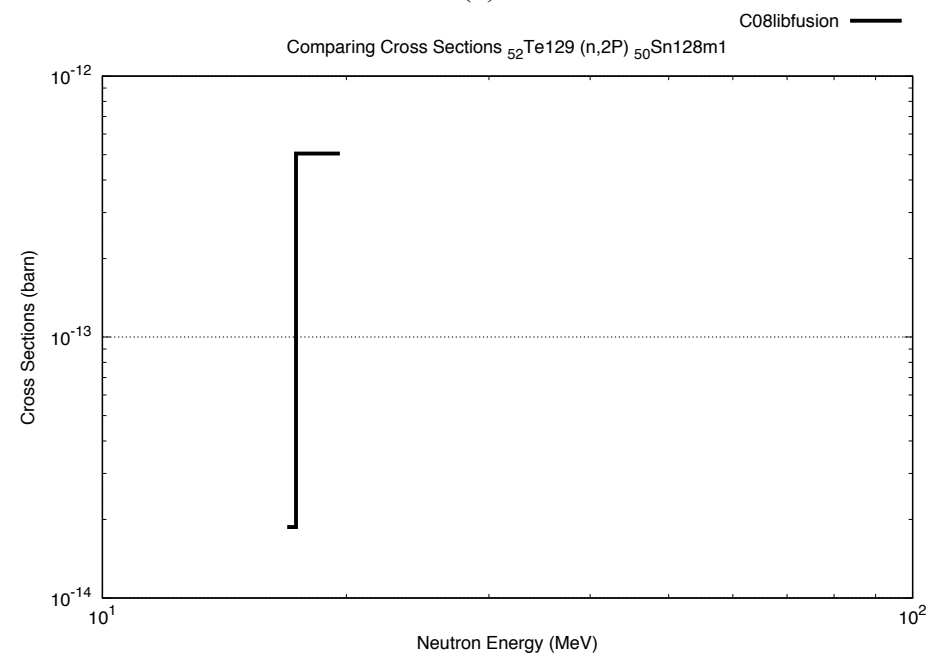

(b)

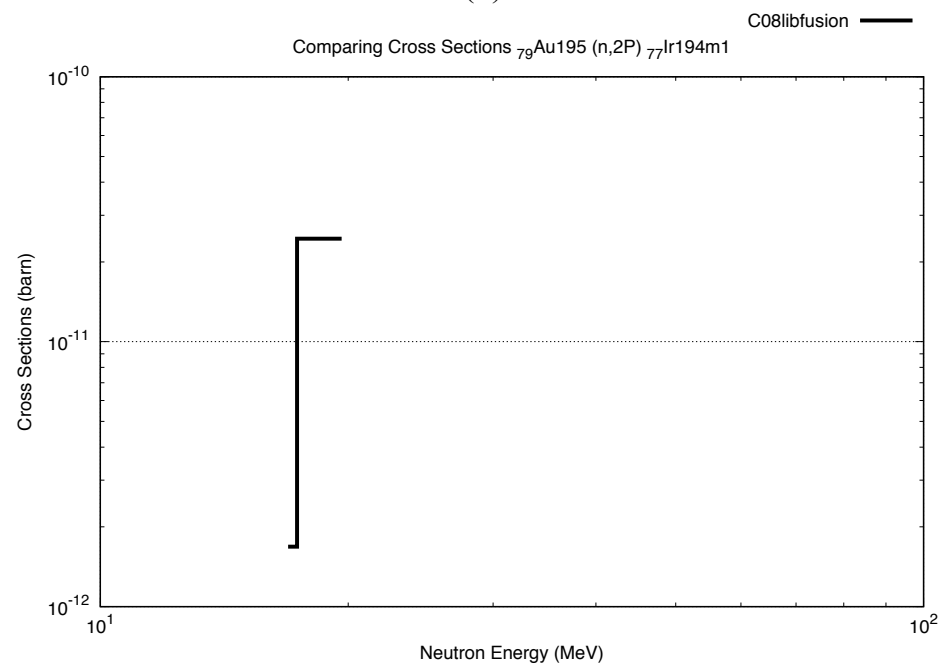

(c)

Figure 12. Examples of reaction cross sections presentin the current CINDER2008 fusion-weighted library but not in the updated CINDER2008 fusion-weighted library. 
On the other side, there are 6 reaction cross sections present in the updated CINDER2008 fusionweighted library but not in the current one. Four of them, shown in Fig. 13, are actually significant cross sections accidentally missed in the current CINDER2008 fusion-weighted library similar to the case of the current flat-weighted library in Section 3.2. The other 2 reaction cross sections, shown in Fig. 14, are just insignicant cross sections around the cut-off limit of the CINDER2008 library maker tool.

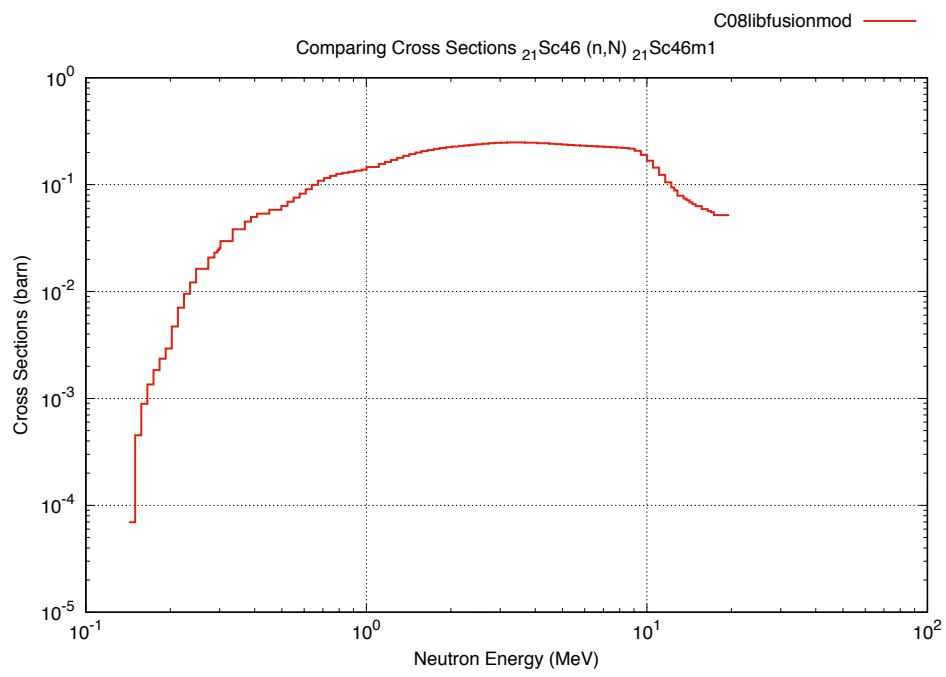

(a)

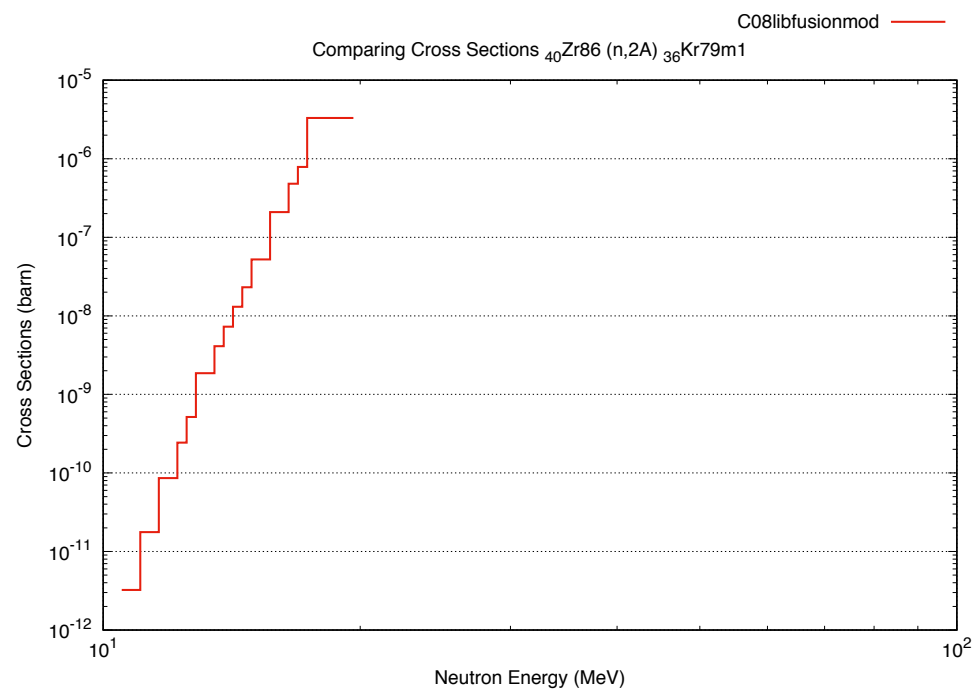

(b) 


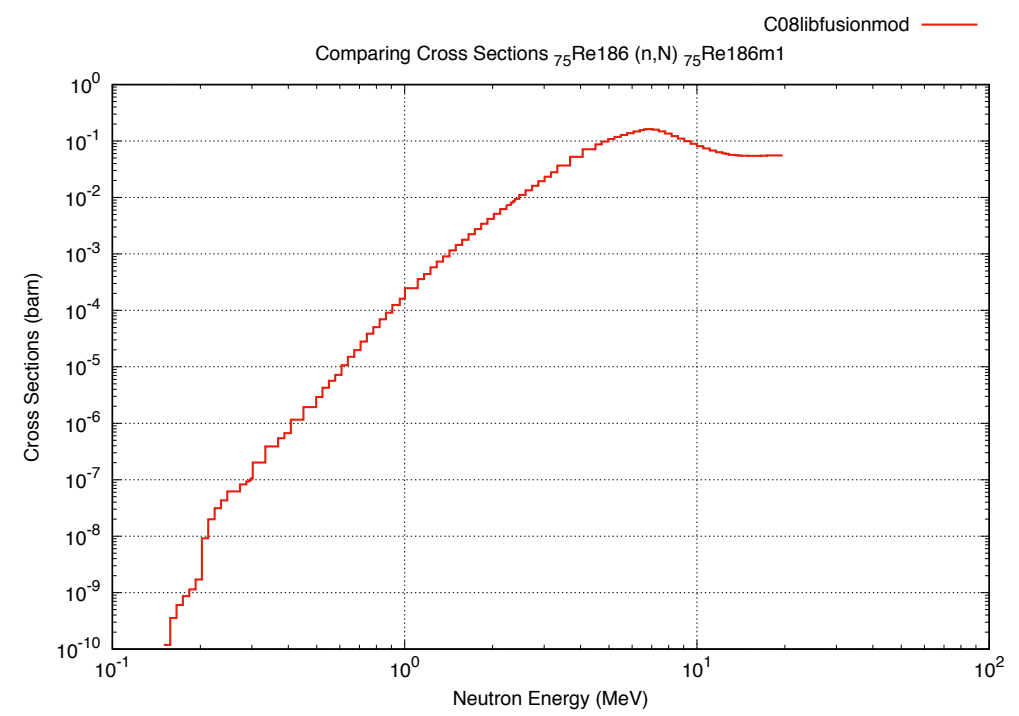

(c)

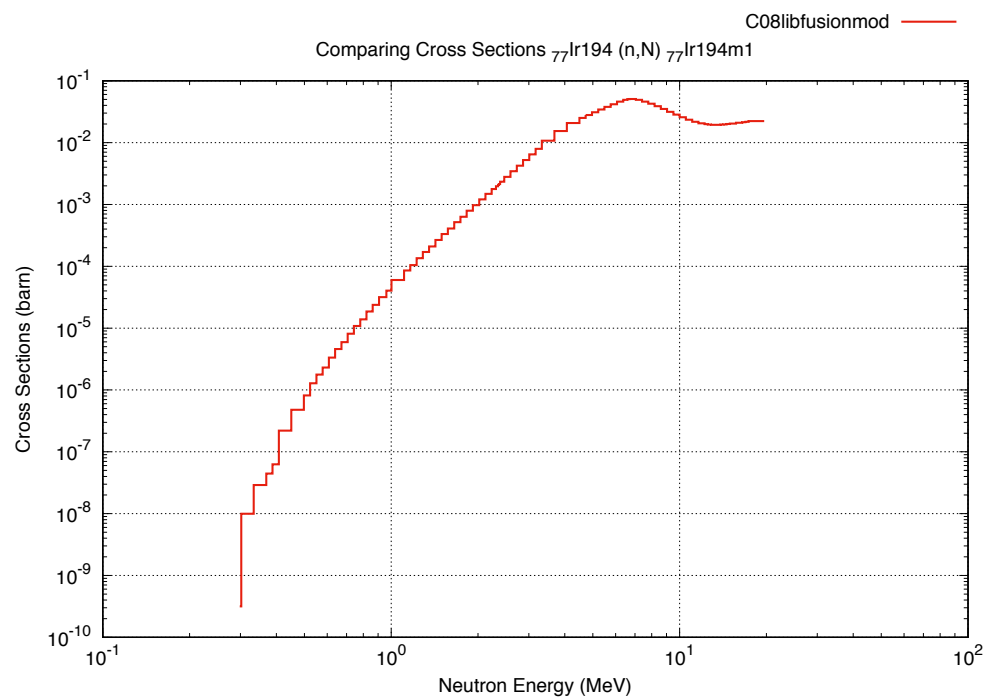

(d)

Figure 13. Reaction cross sections missed in the current CINDER2008 fusion-weighted library but fixed in the updated fusion-weighted library. 


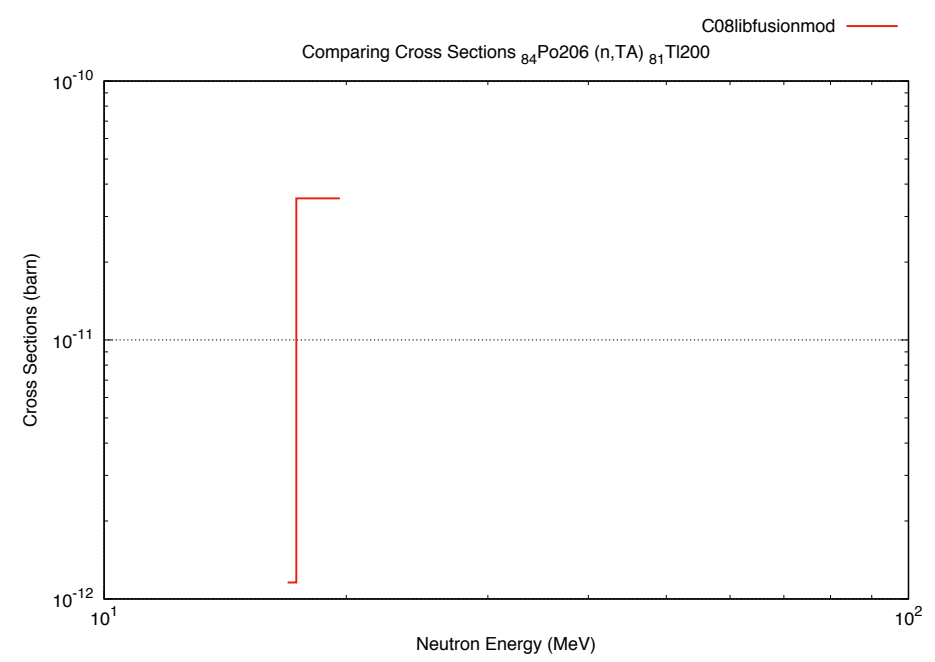

(a)

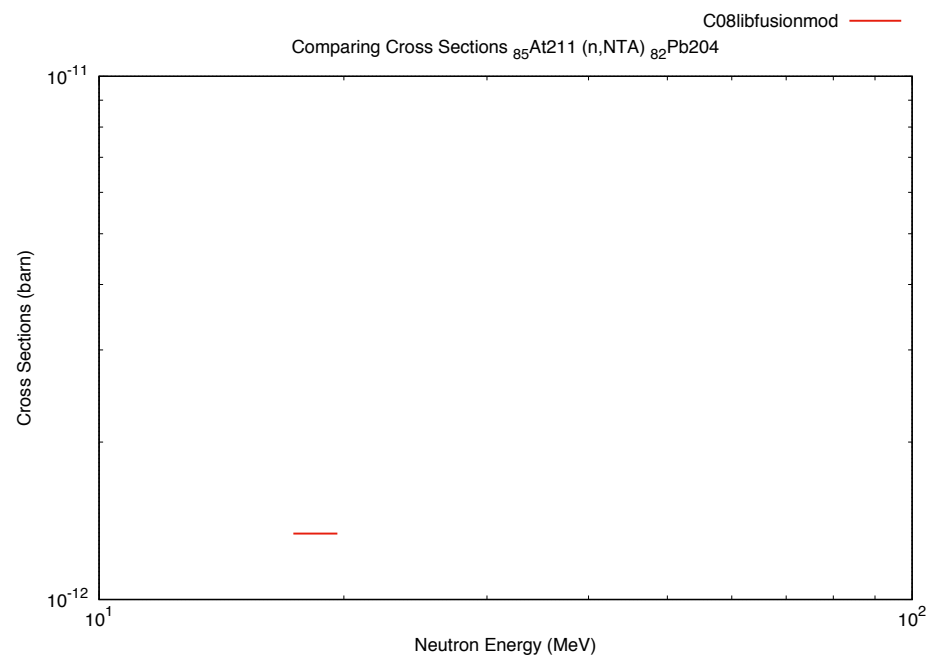

(b)

Figure 14. Reaction cross sections with insignificant values not in the current CINDER2008 fusion-weighted library but present in the updated CINDER2008 fusion-weighted library.

Similar to the case of the current flat-weighted library, there are a great number of reaction cross sections showing significant difference between the current and updated CINDER2008 fusion-weighted libraries. The total number of such reaction cross sections is 2701,1965 of which is due to the truncation issue discussed in the previous section. The full list of the 1965 reaction cross sections could be found in Appendix B. A few examples of such cross sections are illustrated in Fig. 15. They all show the truncation below $\sim 0.6 \mathrm{MeV}$ in the current CINDER2008 fusion-weighted library but the complete spectrum down to the lowest energy group $(1 \mathrm{E}-11-1 \mathrm{E}-7 \mathrm{MeV})$ in the updated fusion-weighted library. 


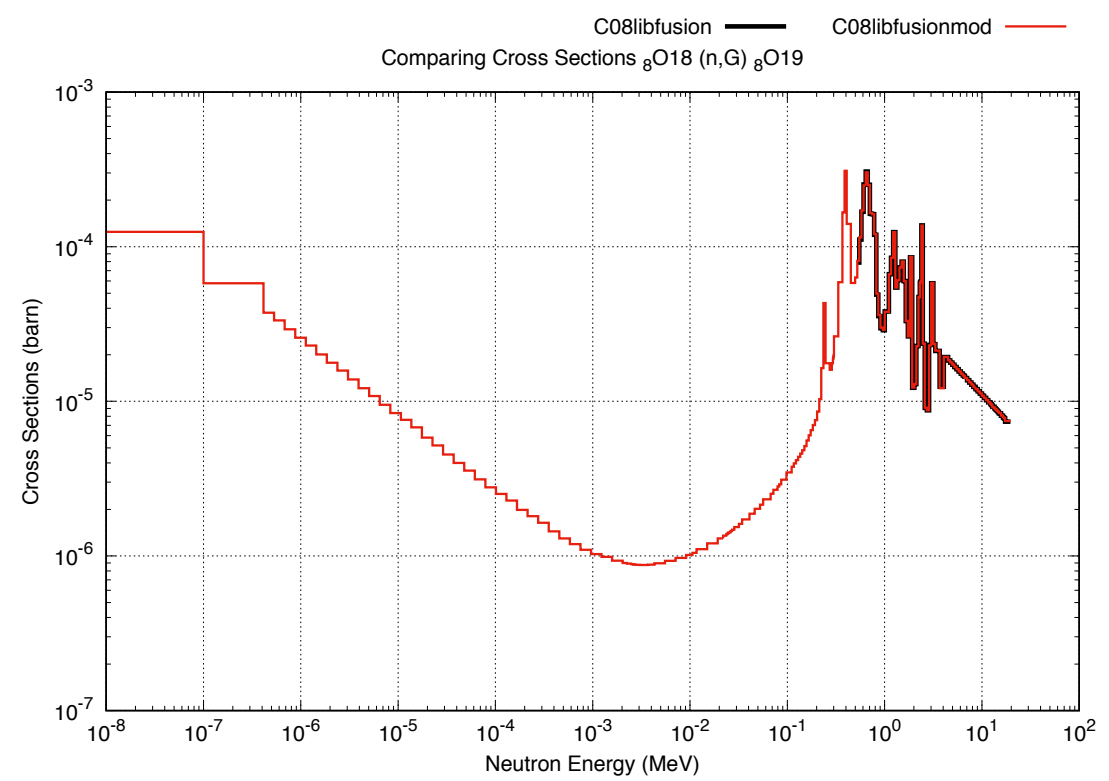

(a)

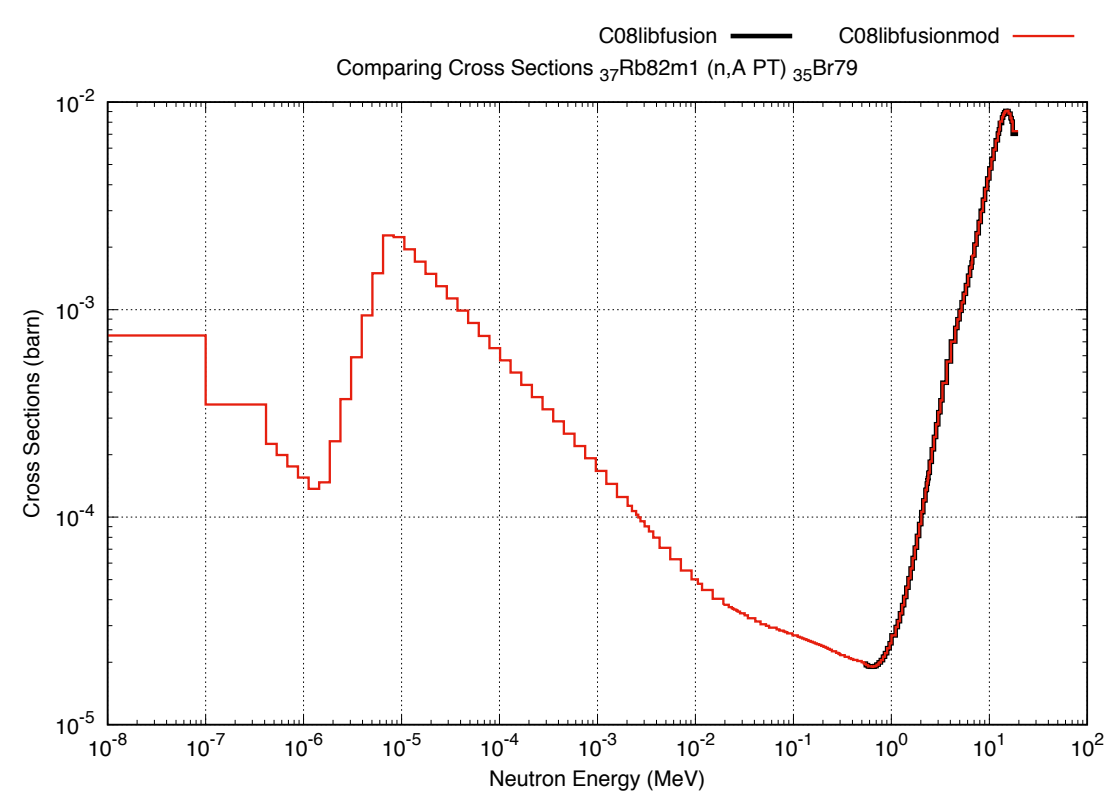

(b) 


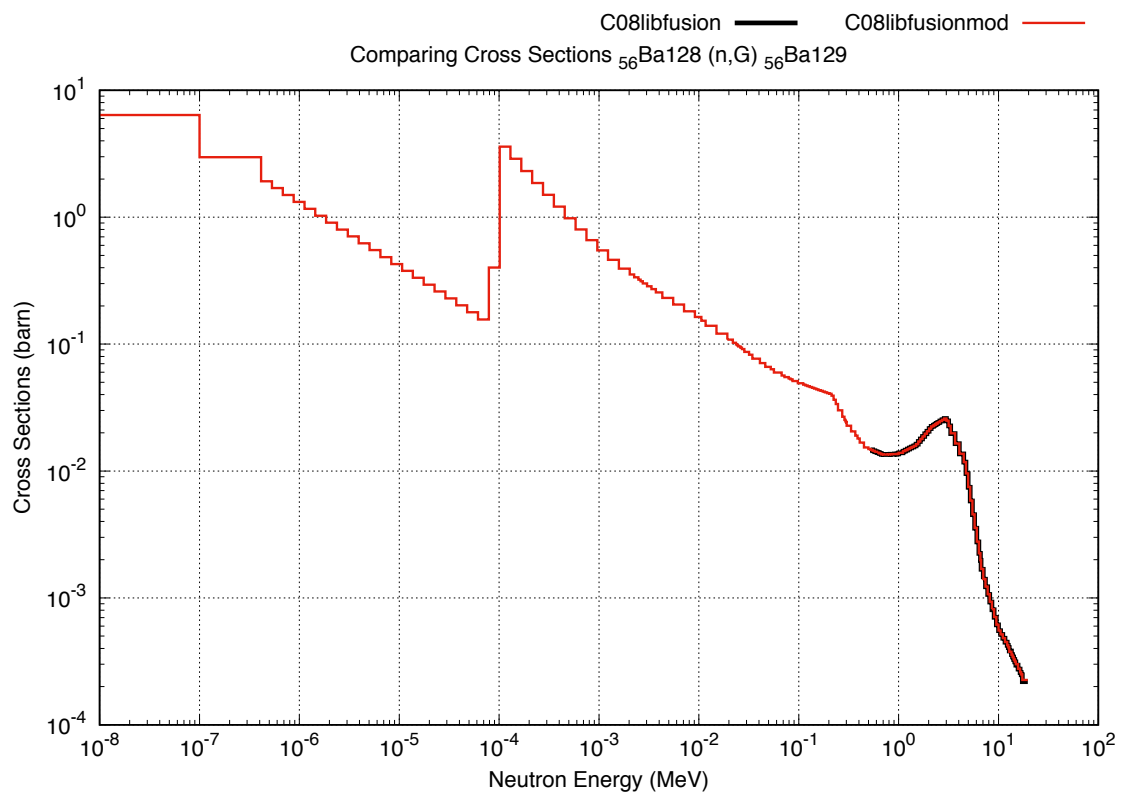

(c)

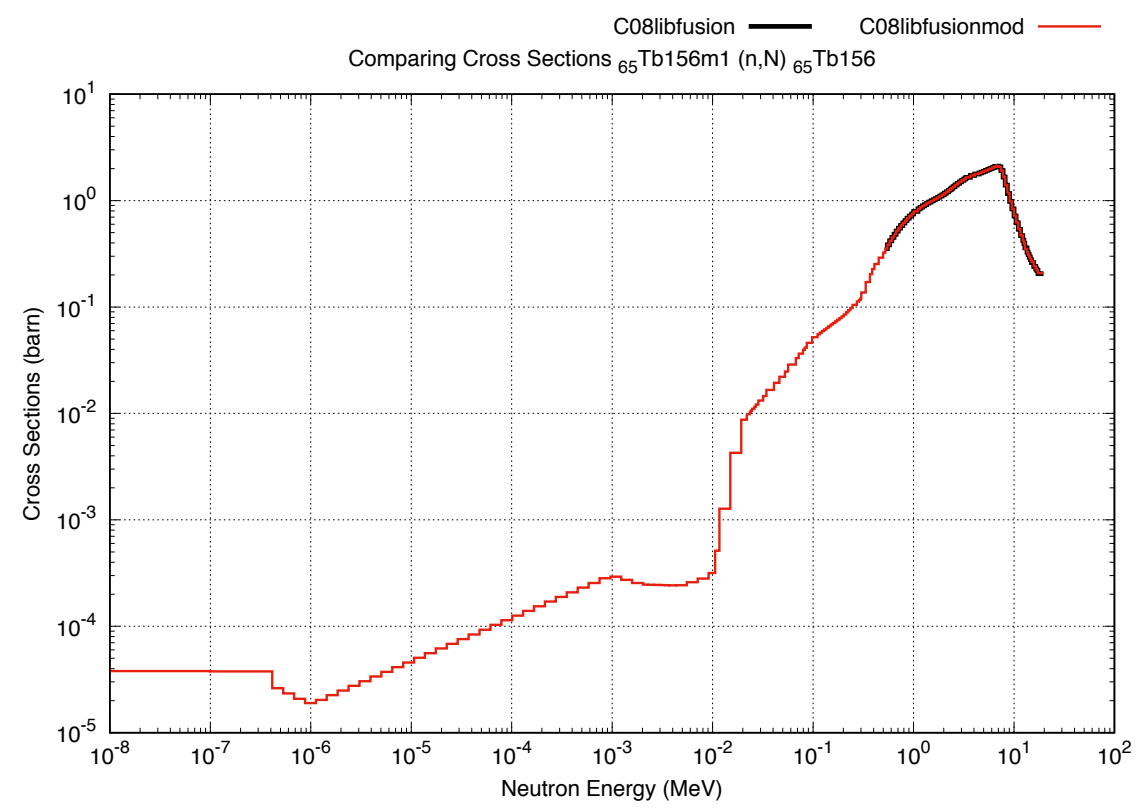

(d) 


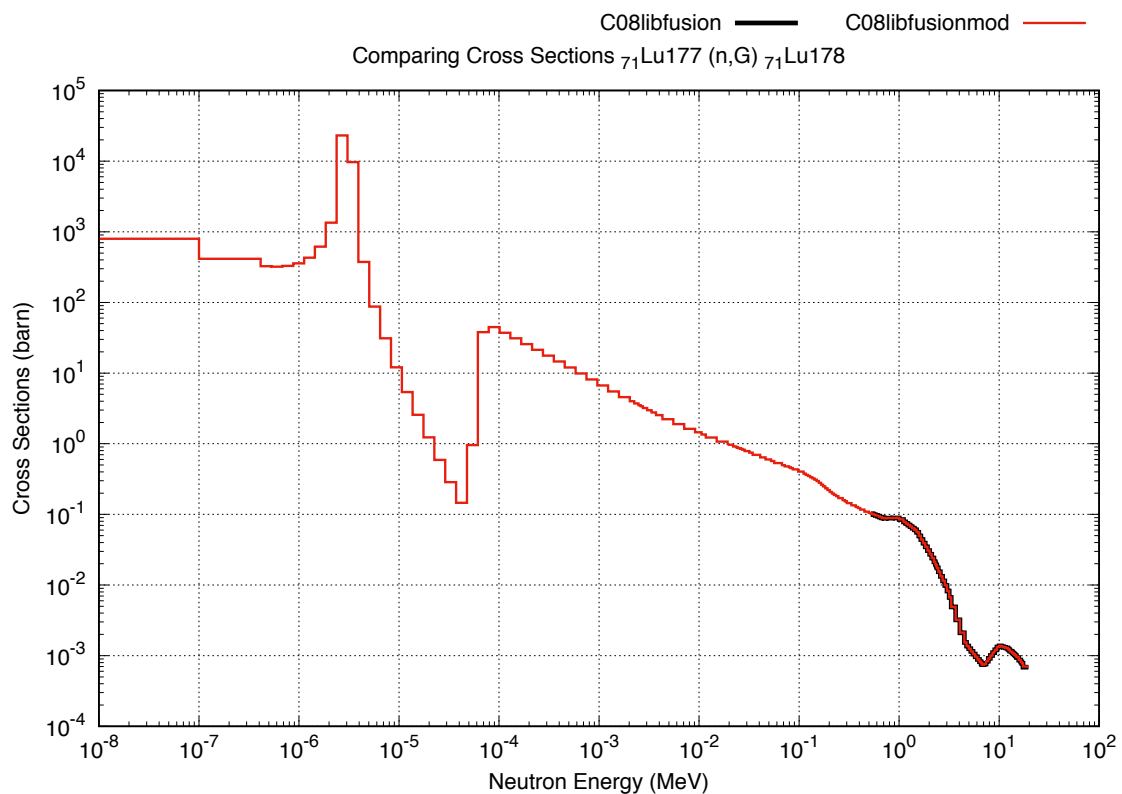

(e)

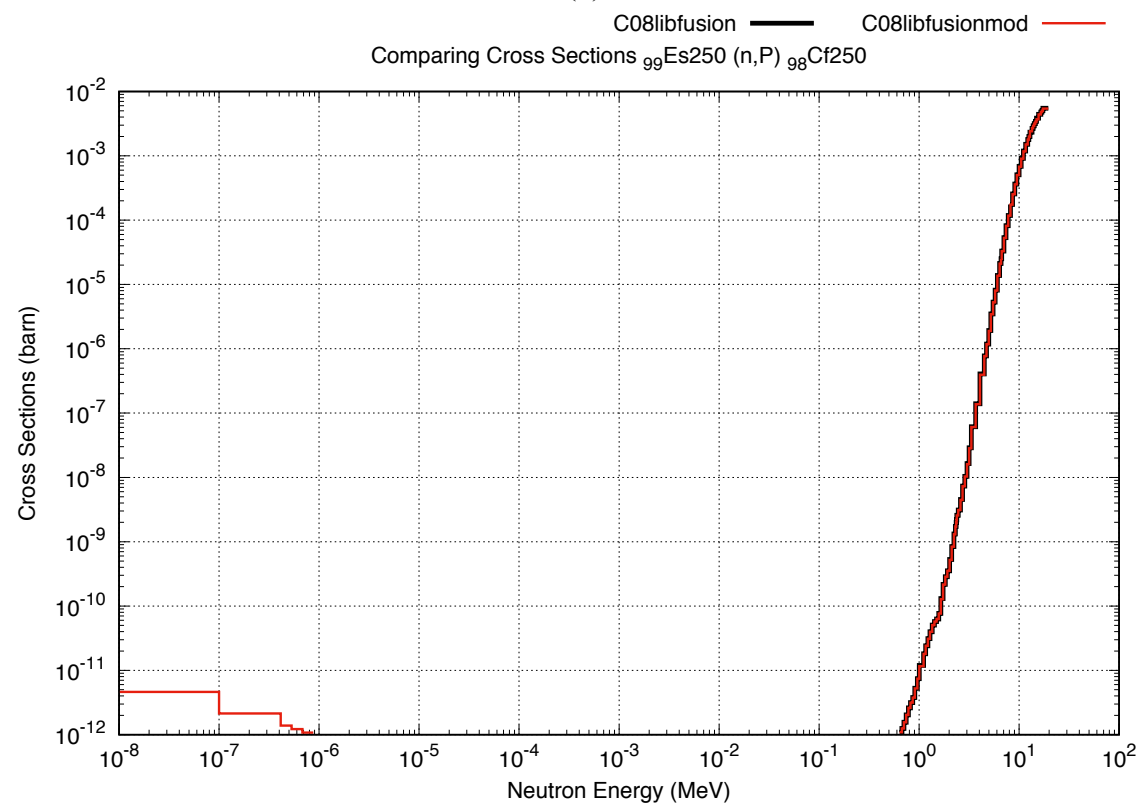

(f)

Figure 15. Examples of reaction cross sections truncated below $\sim 0.6 \mathrm{MeV}$ in the current CINDER2008 fusionweighted library but fixed in the updated CINDER2008 fusion-weighted library (lowest energy bin stops at 1E-8 $\mathrm{MeV}$ to illustrate the lowest energy group $1 \mathrm{E}-11-1 \mathrm{E}-7 \mathrm{MeV})$.

For the remaining 736 reaction cross sections with significant difference between the current and updated fusion-weighted library, the discrepancy in majority of them is limited to just one or two energy groups. Therefore, they are not of serious concern. However, nine of them as shown in Fig. 16 have reaction cross sections with significant difference covering a big fraction of the compelte spectrum. They may require closer examination. 


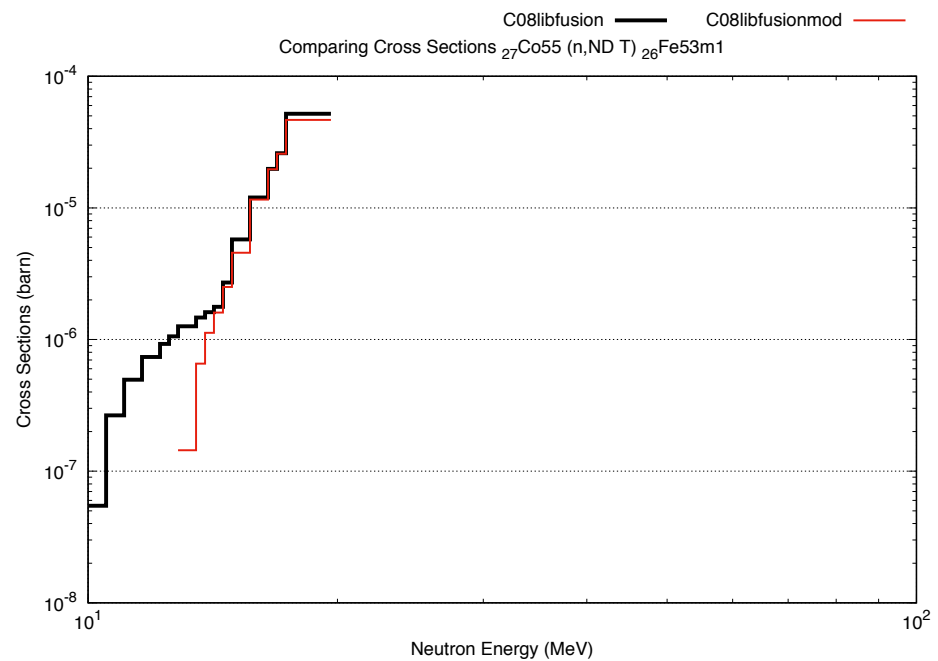

(a)

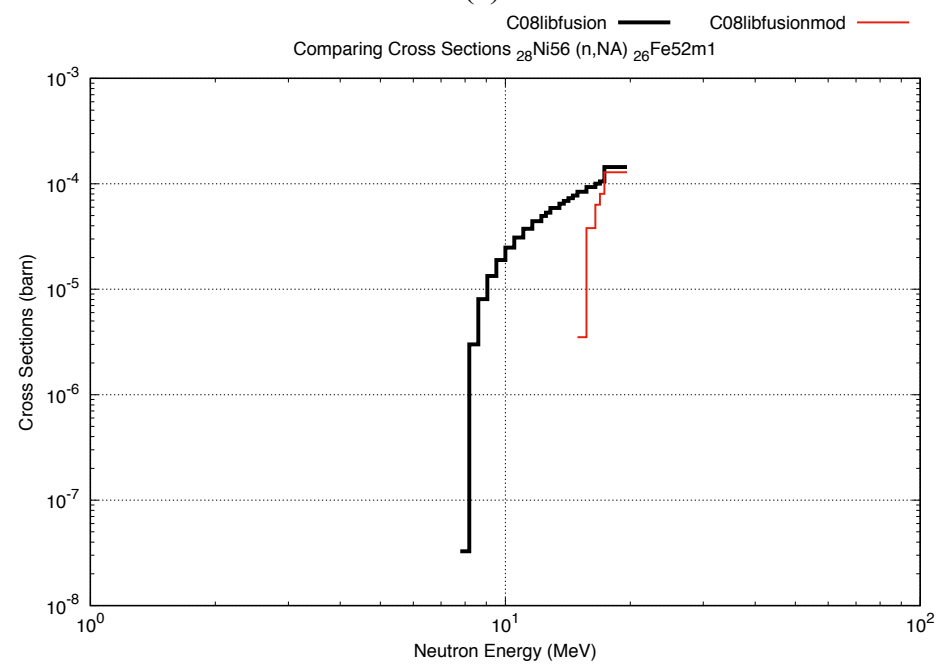

(b)

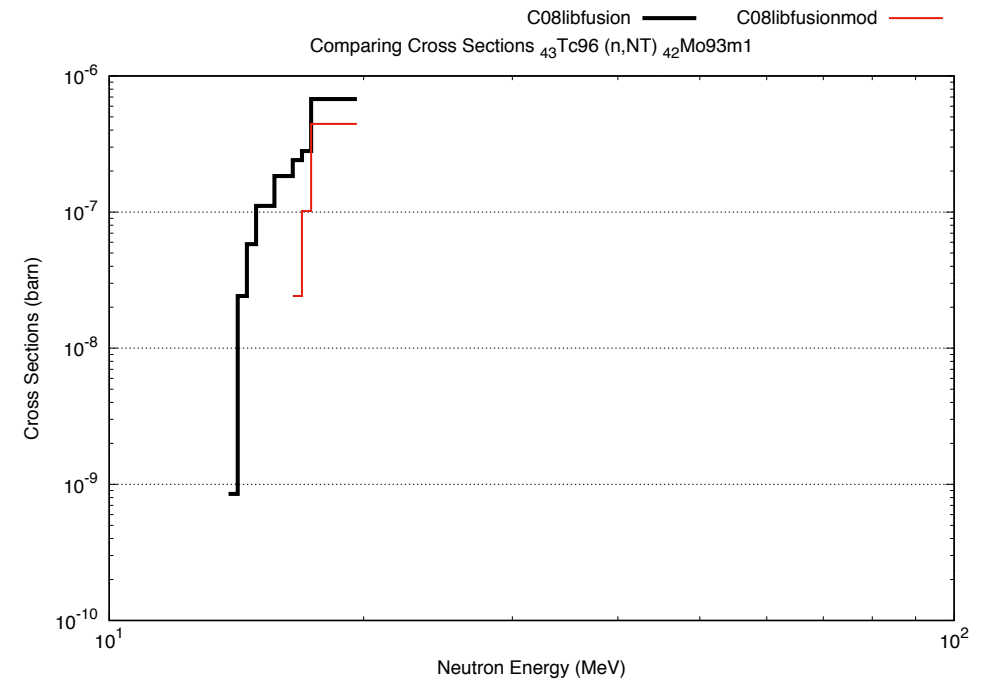

(c) 
C08libfusion $-\quad$ Co8libfusionmod -

Comparing Cross Sections ${ }_{72} \mathrm{Hf} 178 \mathrm{~m} 2(\mathrm{n}, \mathrm{G}){ }_{72} \mathrm{Hf} 179 \mathrm{~m} 2$

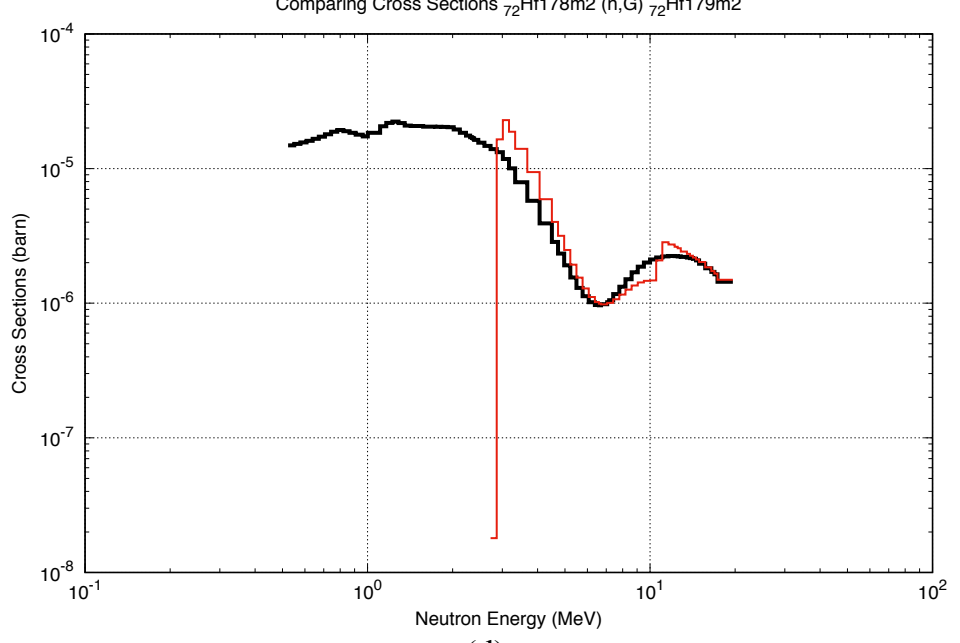

(d)

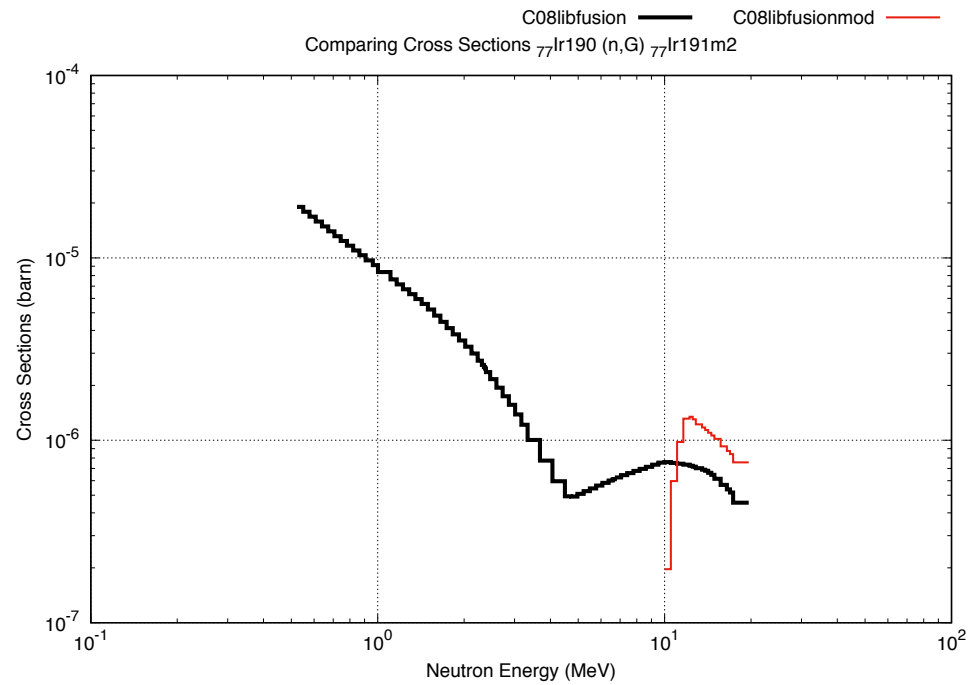

(e)

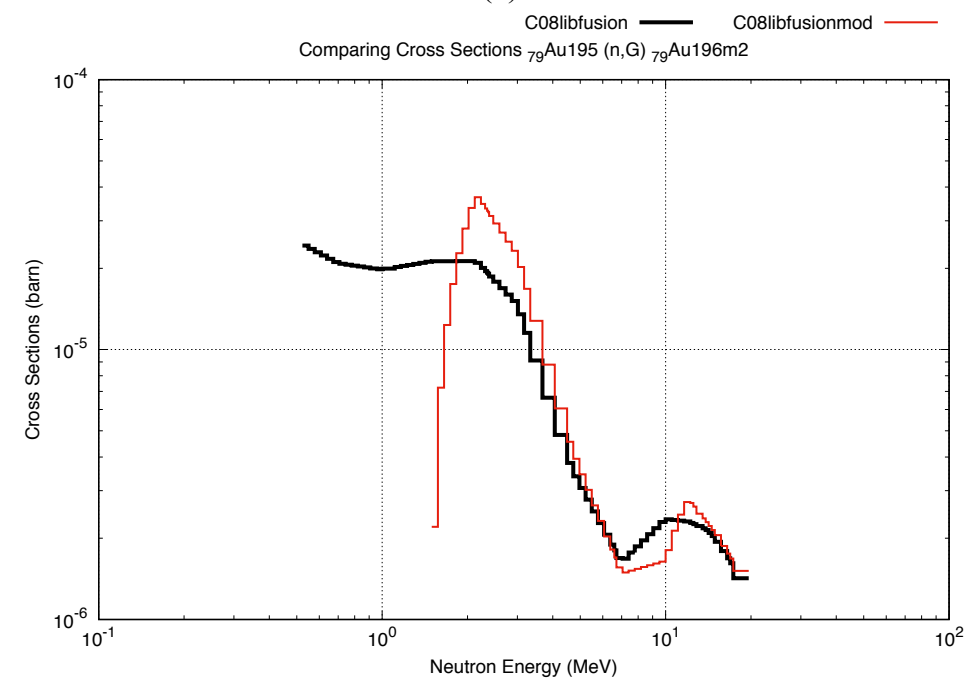

(f) 


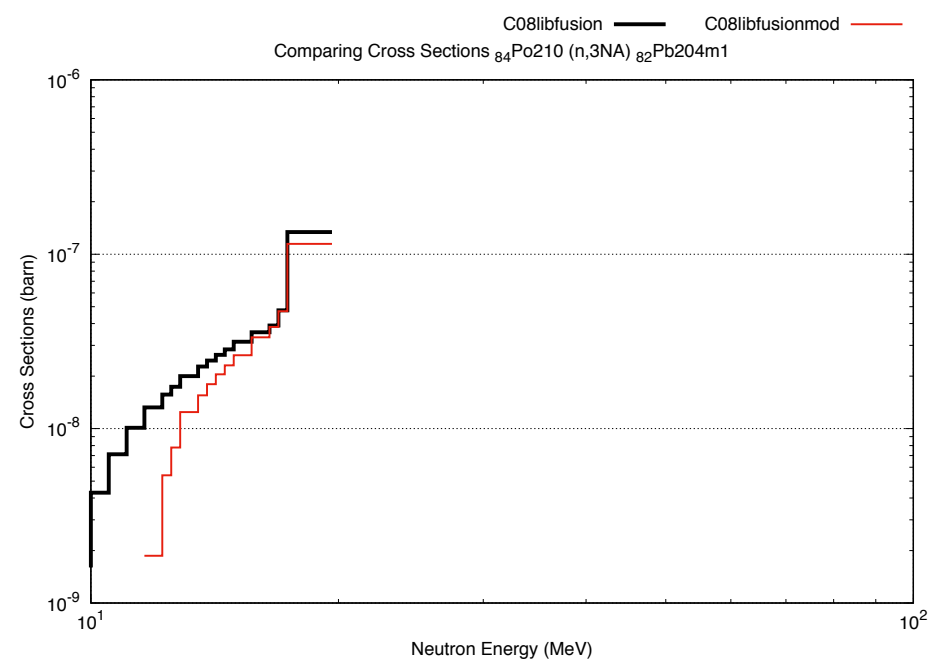

(g)

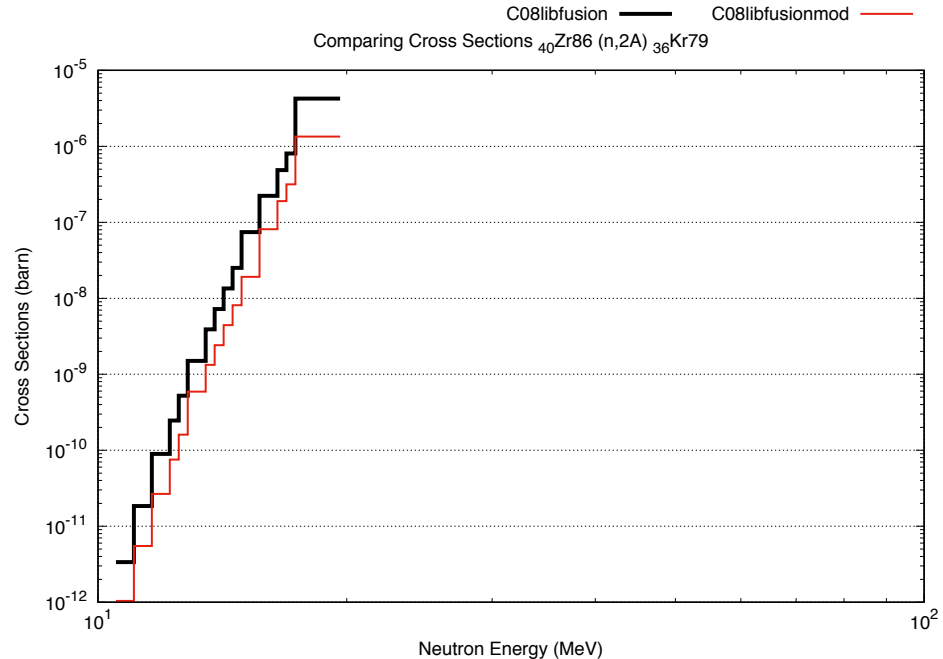

(h)

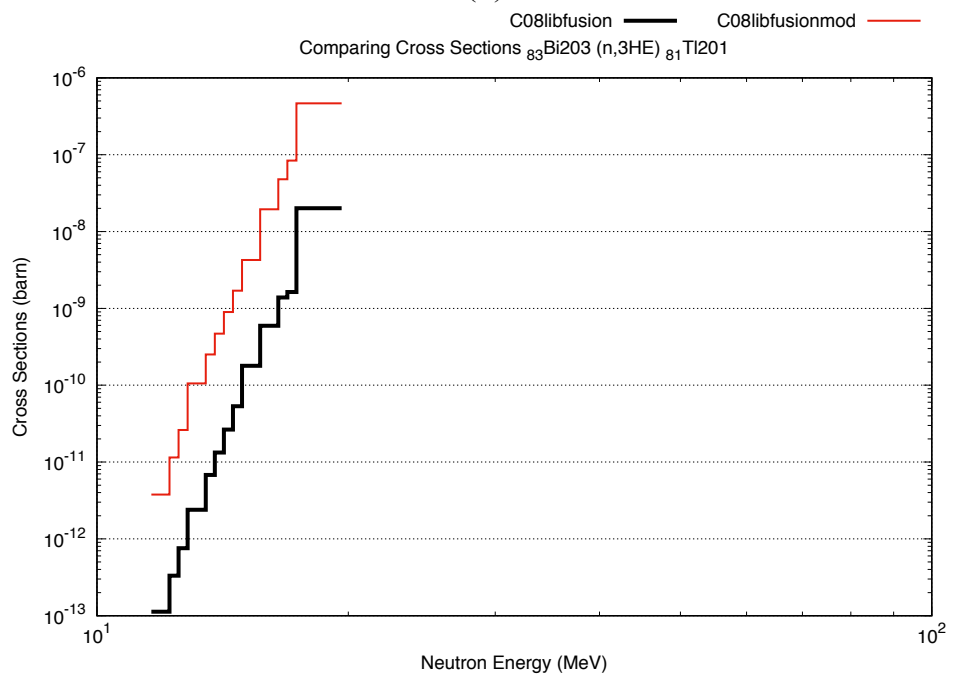

(i)

Figure 16. Reaction cross sections with significant difference between the current CINDER2008 fusion-weighted library and the updated one, which may require further examination. 


\section{SUMMARY}

The recent EAF-2010 cross section data were reprocessed in compatible format into updated libraries for CINDER2008. The results of the updated CINDER2008 cross section libraries were presented and discussed. It is evident that the current version of the CINDER2008 libraries have truncation issues in their flat- and fusion-weighted cross sections taken from EAF-2010, which affect $\sim 15-20 \%$ of the total reaction cross sections. The updated CINDER2008 libraries using the complete EAF-2010 libraries show results that do not suffer from truncation. However, we find that there are still discrepancies between the current and updated CINDER2008 libraries. This is observed by comparing the results of the fission libraries. Other cross section differences are mainly due to the treatment of the CINDER2008 library maker tool in cutting off insignificant cross sections and in dealing with incomplete isomer cross sections. The library maker tool evolved during the CINDER2008 development therefore the inconsistency lingered.

In general, the differences between the current and updated CINDER2008 libraries are all reasonably accounted and the updated libraries should be used with the CINDER2008 code, rather than the libraries distributed prior to October 2016. The library version can be most reliably distinguished by examining the first line of the (text format) library file. The current libraries show processing dates in March, 2011, while the updated libraries show processing dates in September, 2016.

\section{REFERENCES}

1. S. T. Holloway, W. B. Wilson, C. T. Kelsey, IV, H. Little and V. Mozin, A Manual for CINDER2008 Codes and Data, LA-UR 11-00006, Los Alamos National Laboratory, Los Alamos, NM, USA, Mar. 2011.

2. J.-Ch. Sublet, L. W. Packer, J. Kopecky, R. A. Forrest, A. J. Koning and D. A. Rochman, The European Activation File: EAF-2010 neutron-induced cross section library, CCFE-R (10) 05, EURATOM/CCFE Fusion Association, Culham Science Centre, Abingdon, Oxfordshire, OX14 3DB, United Kingdom, Apr. 2010.

3. W. B. Wilson, S. T. Cowell, T. R. England, A. C. Hayes and P. Moller, A Manual for CINDER'90 Version 07.4 Codes and Data, LA-UR-07-8412, Los Alamos National Laboratory, Los Alamos, NM, USA, Mar. 2008.

4. M. B. Chadwick, P. Oblozinsky, M. Herman, N. M. Greene, R. D. McKnight, D. L. Smith, P. G. Young, R. E. MacFarlane, G. M. Hale, R. C. Haight, S. Frankle, A. C. Kahler, T. Kawano, R. C. Little, D. G. Madland, P. Moller, R. Mosteller, P. Page, P. Talou, H. Trellue, M. White, W. B. Wilson, R. Arcilla, C. L. Dunford, S. F. Mughabghab, B. Pritychenko, D. Rochman, A. A. Sonzogni, C. Lubitz, T. H. Trumbull, J. Weinman, D. Brown, D. E. Cullen, D. Heinrichs, D. McNabb, H. Derrien, M. Dunn, N. M. Larson, L. C. Leal, A. D. Carlson, R. C. Block, B. Briggs, E. Cheng, H. Huria, K. Kozier, A. Courcelle, V. Pronyaev, and S. C. van der Marck, ENDF/B-VII.0: Next Generation Evaluated Nuclear Data Library for Nuclear Science and Technology, Nuclear Data Sheets Vol. 107, Issue 12, 2931-3060, Dec. 2006.

5. K. Shibata, O. Iwamoto, T. Nakagawa, N. Iwamoto, A. Ichihara, S. Kunieda, S. Chiba, K. Furutaka, N. Otuka, T. Ohsawa, T. Murata, H. Matsunobu, A. Zukeran, S. Kamada, and J. Katakura, JENDL-4.0: A New Library for Nuclear Science and Engineering, J. Nucl. Sci. Technol. 48(1), 1-30 (2011). 
6. http://t2.lanl.gov/nis/data/jeff/EAF2010.html as of July 22, 2016

7. https://rsicc.ornl.gov/codes/psr/psr4/psr-480.html as of July 6, 2017

8. R. E. MacFarlane and D. W. Muir, “The NJOY Nuclear Data Processing System Version 91,” LA12740-M, October 1994.

9. R. E. MacFarlane, "New Thermal Neutron Scattering Files for ENDF/B-VI, Release 2," LA-12639-MS (ENDF 356), March 1994.

10. R. E. MacFarlane and D. C. George, "UPD: A Portable Version-Control Program,” LA-12057-MS, April 1991.

11. R. E. MacFarlane, "How to NJOY ENDF-6," The International Workshop on NJOY, Saclay, France, April 1992. 


\section{APPENDIX A.}

List of 2787 truncated reaction cross sections in the current CINDER2008 flat-weighted library but fixed in the updated CINDER2008 flat-weighted library.

\begin{tabular}{|c|c|}
\hline Target Nucl. & Reactions \\
\hline $4 \mathrm{Be} 7$ & $(n, X \backslash P)(n, X \backslash A)(n, P)(n, G)$ \\
\hline $4 \mathrm{Be} 10$ & $(\mathrm{n}, \mathrm{G})$ \\
\hline $6 \mathrm{C} 12$ & $(n, G)$ \\
\hline $6 \mathrm{C} 13$ & $(n, G)$ \\
\hline $6 \mathrm{C} 14$ & $(n, G)$ \\
\hline 8018 & $(\mathrm{n}, \mathrm{G})$ \\
\hline $10 \mathrm{Ne} 20$ & $(n, X \backslash A)(n, N 3 H E P T)(n, G)$ \\
\hline $10 \mathrm{Ne} 21$ & $(\mathrm{n}, \mathrm{X} \backslash \mathrm{A})(\mathrm{n}, \mathrm{N} 3 \mathrm{HE}$ A PT) $(\mathrm{n}, \mathrm{G})$ \\
\hline $10 \mathrm{Ne} 22$ & $(\mathrm{n}, \mathrm{G})$ \\
\hline $11 \mathrm{Na} 24$ & $(n, G)$ \\
\hline $12 \mathrm{Mg} 28$ & $(n, G)$ \\
\hline $13 \mathrm{Al} 26$ & $(n, X \backslash P)(n, X \backslash A)(n, N 3 H E$ A PT NPD) $(n, P)(n, G)$ \\
\hline $14 \mathrm{Si} 31$ & $(n, G)$ \\
\hline $14 \mathrm{Si32}$ & $(n, G)$ \\
\hline $15 \mathrm{P} 32$ & $(n, X \backslash P)(n, X \backslash A)(n, N 3 H E P T)(n, P)(n, G)$ \\
\hline $15 \mathrm{P} 33$ & $(n, G)$ \\
\hline $16 \mathrm{~S} 35$ & $(\mathrm{n}, \mathrm{X} \backslash \mathrm{A})(\mathrm{n}, \mathrm{N} 3 \mathrm{HE} \mathrm{A} \mathrm{PT})(\mathrm{n}, \mathrm{G})$ \\
\hline $17 \mathrm{Cl} 36$ & $(\mathrm{n}, \mathrm{X} \backslash \mathrm{P})(\mathrm{n}, \mathrm{X} \backslash \mathrm{A})(\mathrm{n}, \mathrm{N} 3 \mathrm{HE}$ A PT) $(\mathrm{n}, \mathrm{P})(\mathrm{n}, \mathrm{G})$ \\
\hline $18 \operatorname{Ar} 37$ & $(n, X \backslash P)(n, X \backslash A)(n, N 3 H E$ A PT NPD) $(n, P)(n, G)$ \\
\hline $18 \operatorname{Ar} 39$ & $(n, X \backslash A)(n, N 3 H E$ A PT NPD) $(n, G)$ \\
\hline $18 \operatorname{Ar} 41$ & $(n, X \backslash A)(n, N 3 H E P T)(n, G)$ \\
\hline $18 \operatorname{Ar} 42$ & $(n, G)$ \\
\hline $19 \mathrm{~K} 42$ & $(n, X \backslash P)(n, X \backslash A)(n, N 3 H E$ A PT) $(n, P)(n, G)$ \\
\hline $19 \mathrm{~K} 43$ & $(\mathrm{n}, \mathrm{G})$ \\
\hline $20 \mathrm{Ca} 41$ & $(n, X \backslash P)(n, X \backslash A)(n, N 3 H E$ A PT NPD 2N2P) $(n, P)(n, G)$ \\
\hline $20 \mathrm{Ca} 45$ & $(n, X \backslash A)(n, N 3 H E P T)(n, G)$ \\
\hline $20 \mathrm{Ca} 47$ & $(n, G)$ \\
\hline $21 \mathrm{Sc} 44 \mathrm{~m} 1$ & $(n, X \backslash P)(n, X \backslash A)(n, N 3 H E$ A PT NPD) $(n, P)(n, N)(n, G)(n, G)$ \\
\hline $21 \mathrm{Sc} 46$ & $(n, X \backslash P)(n, X \backslash A)(n, N 3 H E A$ PT $)(n, P)(n, N)(n, G)$ \\
\hline $21 \mathrm{Sc} 47$ & $(\mathrm{n}, \mathrm{G})$ \\
\hline $21 \mathrm{Sc} 48$ & $(\mathrm{n}, \mathrm{X} \backslash \mathrm{P})(\mathrm{n}, \mathrm{P})(\mathrm{n}, \mathrm{G})$ \\
\hline $22 \mathrm{Ti} 44$ & $(n, X \backslash P)(n, X \backslash A)(n, N 3 H E$ A PT NPD) $(n, P)(n, P)(n, G)$ \\
\hline $22 \mathrm{Ti45}$ & $(n, X \backslash P)(n, X \backslash A)(n, N 3 H E$ A PT NPD) $(n, P)(n, P)(n, G)$ \\
\hline $23 \mathrm{~V} 48$ & $(n, X \backslash P)(n, X \backslash A)(n, N 3 H E A$ PT) $(n, N 3 H E$ A PT) $(n, P)(n, G)$ \\
\hline
\end{tabular}




\begin{tabular}{|c|c|}
\hline Target Nucl. & Reactions \\
\hline 23V49 & $(\mathrm{n}, \mathrm{X} \backslash \mathrm{P})(\mathrm{n}, \mathrm{X} \backslash \mathrm{A})(\mathrm{n}, \mathrm{N} 3 \mathrm{HE} \mathrm{PT})(\mathrm{n}, \mathrm{N} 3 \mathrm{HE} \mathrm{PT})(\mathrm{n}, \mathrm{P})(\mathrm{n}, \mathrm{G})$ \\
\hline $24 \mathrm{Cr} 48$ & $(\mathrm{n}, \mathrm{X} \backslash \mathrm{P})(\mathrm{n}, \mathrm{X} \backslash \mathrm{A})(\mathrm{n}, \mathrm{N} 3 \mathrm{HE}$ A PT) $(\mathrm{n}, \mathrm{P})(\mathrm{n}, \mathrm{G})$ \\
\hline $24 \mathrm{Cr} 51$ & $(n, X \backslash P)(n, X \backslash A)(n, N 3 H E A P T)(n, P)(n, G)$ \\
\hline $25 \mathrm{Mn} 52$ & $(\mathrm{n}, \mathrm{X} \backslash \mathrm{P})(\mathrm{n}, \mathrm{X} \backslash \mathrm{A})(\mathrm{n}, \mathrm{N} 3 \mathrm{HE} \mathrm{A} \mathrm{PT})(\mathrm{n}, \mathrm{P})(\mathrm{n}, \mathrm{G})$ \\
\hline $25 \mathrm{Mn} 53$ & $(\mathrm{n}, \mathrm{X} \backslash \mathrm{P})(\mathrm{n}, \mathrm{X} \backslash \mathrm{A})(\mathrm{n}, \mathrm{N} 3 \mathrm{HE}$ A PT) $(\mathrm{n}, \mathrm{P})(\mathrm{n}, \mathrm{G})$ \\
\hline $25 \mathrm{Mn} 54$ & $(n, X \backslash P)(n, X \backslash A)(n, N 3 H E A$ PT) $(n, P)(n, G)$ \\
\hline $26 \mathrm{Fe} 52$ & $(n, X \backslash P)(n, X \backslash A)(n, N 3 H E A$ PT) $(n, P)(n, P)(n, G)(n, G)$ \\
\hline $26 \mathrm{Fe} 55$ & $(n, X \backslash P)(n, X \backslash A)(n, N 3 H E$ A PT) $(n, P)(n, G)$ \\
\hline $26 \mathrm{Fe} 60$ & $(n, G)$ \\
\hline $27 \operatorname{Co55}$ & $(n, X \backslash P)(n, X \backslash A)(n, N 3 H E$ A PT) $(n, N 3 H E$ A PT) $(n, P)(n, G)$ \\
\hline $27 \operatorname{Co56}$ & $(\mathrm{n}, \mathrm{X} \backslash \mathrm{P})(\mathrm{n}, \mathrm{X} \backslash \mathrm{A})(\mathrm{n}, \mathrm{N} 3 \mathrm{HE}$ A PT NPD) $(\mathrm{n}, \mathrm{P})(\mathrm{n}, \mathrm{G})$ \\
\hline $27 \operatorname{Co57}$ & $(n, X \backslash P)(n, X \backslash A)(n, N 3 H E$ A PT) $(n, P)(n, G)(n, G)$ \\
\hline $27 \mathrm{Co60}$ & $(n, X \backslash P)(n, X \backslash A)(n, N 3 H E$ A PT) $(n, P)(n, N)(n, G)$ \\
\hline $28 \mathrm{Ni} 56$ & $(n, X \backslash P)(n, X \backslash A)(n, N 3 H E$ PT A NPD) $(n, N 3 H E P T)(n, P)(n, G)$ \\
\hline $28 \mathrm{Ni} 57$ & $(n, X \backslash P)(n, X \backslash A)(n, N 3 H E$ A PT NPD) $(n, P)(n, G)$ \\
\hline $28 \mathrm{Ni} 63$ & $(\mathrm{n}, \mathrm{X} \backslash \mathrm{A})(\mathrm{n}, \mathrm{N} 3 \mathrm{HE} \mathrm{A} \mathrm{PT})(\mathrm{n}, \mathrm{G})$ \\
\hline $28 \mathrm{Ni} 66$ & $(n, G)$ \\
\hline $29 \mathrm{Cu} 64$ & $(\mathrm{n}, \mathrm{X} \backslash \mathrm{P})(\mathrm{n}, \mathrm{X} \backslash \mathrm{A})(\mathrm{n}, \mathrm{N} 3 \mathrm{HE} \mathrm{A} \mathrm{PT})(\mathrm{n}, \mathrm{P})(\mathrm{n}, \mathrm{G})$ \\
\hline $29 \mathrm{Cu} 67$ & $(n, G)(n, G)$ \\
\hline $30 \mathrm{Zn} 62$ & $(n, X \backslash P)(n, X \backslash A)(n, N 3 H E$ A PT NPD) $(n, P)(n, G)$ \\
\hline $30 \mathrm{Zn} 69 \mathrm{~m} 1$ & $(\mathrm{n}, \mathrm{X} \backslash \mathrm{A})(\mathrm{n}, \mathrm{N} 3 \mathrm{HE}$ A PT) $(\mathrm{n}, \mathrm{N})(\mathrm{n}, \mathrm{G})$ \\
\hline $30 \mathrm{Zn} 72$ & $(n, G)(n, G)(n, G)$ \\
\hline $31 \mathrm{Ga} 66$ & $(\mathrm{n}, \mathrm{X} \backslash \mathrm{P})(\mathrm{n}, \mathrm{X} \backslash \mathrm{A})(\mathrm{n}, 2 \mathrm{~A})(\mathrm{n}, \mathrm{PA})(\mathrm{n}, \mathrm{N} 3 \mathrm{HE}$ A PT NPD 2N2P) $(\mathrm{n}, \mathrm{P})(\mathrm{n}, \mathrm{G})$ \\
\hline $31 \mathrm{Ga} 67$ & $(n, X \backslash P)(n, X \backslash A)(n, N 3 H E A$ PT) $(n, P)(n, G)$ \\
\hline $31 \mathrm{Ga} 72$ & $(\mathrm{n}, \mathrm{X} \backslash \mathrm{P})(\mathrm{n}, \mathrm{X} \backslash \mathrm{A})(\mathrm{n}, \mathrm{N} 3 \mathrm{HE} \mathrm{A} \mathrm{PT})(\mathrm{n}, \mathrm{P})(\mathrm{n}, \mathrm{G})$ \\
\hline $32 \mathrm{Ge} 68$ & $(\mathrm{n}, \mathrm{X} \backslash \mathrm{P})(\mathrm{n}, \mathrm{X} \backslash \mathrm{A})(\mathrm{n}, 2 \mathrm{~A})(\mathrm{n}, \mathrm{N} 3 \mathrm{HE}$ A PT NPD) $(\mathrm{n}, \mathrm{P})(\mathrm{n}, \mathrm{G})$ \\
\hline $32 \mathrm{Ge} 69$ & $(\mathrm{n}, \mathrm{X} \backslash \mathrm{P})(\mathrm{n}, \mathrm{X} \backslash \mathrm{A})(\mathrm{n}, 2 \mathrm{~A})(\mathrm{n}, \mathrm{N} 3 \mathrm{HE}$ A PT NPD 2N2P) (n,P) (n,G) \\
\hline $32 \mathrm{Ge} 71$ & $(n, X \backslash P)(n, X \backslash A)(n, 2 A)(n, N 3 H E$ A PT NPD) $(n, P)(n, G)$ \\
\hline $32 \mathrm{Ge} 77$ & $(n, X \backslash A)(n, N 3 H E A)(n, N)(n, G)$ \\
\hline $33 \mathrm{As} 71$ & $(\mathrm{n}, \mathrm{X} \backslash \mathrm{P})(\mathrm{n}, \mathrm{X} \backslash \mathrm{A})(\mathrm{n}, 2 \mathrm{~A})(\mathrm{n}, \mathrm{N} 3 \mathrm{HE} \mathrm{A} \mathrm{PT})(\mathrm{n}, \mathrm{P})(\mathrm{n}, \mathrm{P})(\mathrm{n}, \mathrm{G})$ \\
\hline $33 \mathrm{As} 72$ & $(\mathrm{n}, \mathrm{X} \backslash \mathrm{P})(\mathrm{n}, \mathrm{X} \backslash \mathrm{A})(\mathrm{n}, 2 \mathrm{~A})(\mathrm{n}, \mathrm{PA})(\mathrm{n}, \mathrm{N} 3 \mathrm{HE}$ A PT NPD 2N2P) $(\mathrm{n}, \mathrm{P})(\mathrm{n}, \mathrm{G})$ \\
\hline $33 \mathrm{As} 73$ & $(n, X \backslash P)(n, X \backslash A)(n, N 3 H E$ A PT) $(n, P)(n, P)(n, G)$ \\
\hline $33 \mathrm{As} 76$ & $(\mathrm{n}, \mathrm{X} \backslash \mathrm{P})(\mathrm{n}, \mathrm{X} \backslash \mathrm{A})(\mathrm{n}, \mathrm{N} 3 \mathrm{HE} \mathrm{A} \mathrm{PT})(\mathrm{n}, \mathrm{P})(\mathrm{n}, \mathrm{G})$ \\
\hline 33 As77 & $(\mathrm{n}, \mathrm{X} \backslash \mathrm{A})(\mathrm{n}, \mathrm{N} 3 \mathrm{HE})(\mathrm{n}, \mathrm{G})$ \\
\hline $34 \mathrm{Se} 72$ & $(n, X \backslash P)(n, X \backslash A)(n, 2 A)(n, N 3 H E$ A PT NPD) $(n, P)(n, G)(n, G)$ \\
\hline $34 \mathrm{Se} 73$ & $(\mathrm{n}, \mathrm{X} \backslash \mathrm{P})(\mathrm{n}, \mathrm{X} \backslash \mathrm{A})(\mathrm{n}, 2 \mathrm{~A})(\mathrm{n}, \mathrm{N} 3 \mathrm{HE}$ A PT NPD 2N2P) $(\mathrm{n}, \mathrm{P})(\mathrm{n}, \mathrm{N})(\mathrm{n}, \mathrm{G})$ \\
\hline $34 \mathrm{Se} 75$ & $(\mathrm{n}, \mathrm{X} \backslash \mathrm{P})(\mathrm{n}, \mathrm{X} \backslash \mathrm{A})(\mathrm{n}, 2 \mathrm{~A})(\mathrm{n}, \mathrm{N} 3 \mathrm{HE}$ A PT NPD) $(\mathrm{n}, \mathrm{P})(\mathrm{n}, \mathrm{G})$ \\
\hline $35 \mathrm{Br} 76$ & $(\mathrm{n}, \mathrm{X} \backslash \mathrm{P})(\mathrm{n}, \mathrm{X} \backslash \mathrm{A})(\mathrm{n}, 2 \mathrm{~A})(\mathrm{n}, \mathrm{PA})(\mathrm{n}, \mathrm{N} 3 \mathrm{HE}$ A PT NPD) $(\mathrm{n}, \mathrm{P})(\mathrm{n}, \mathrm{N})(\mathrm{n}, \mathrm{G})(\mathrm{n}, \mathrm{G})$ \\
\hline
\end{tabular}




\begin{tabular}{|c|c|}
\hline Target Nucl. & Reactions \\
\hline $35 \mathrm{Br} 77$ & $(n, X \backslash P)(n, X \backslash A)(n, N 3 H E$ A PT) $(n, P)(n, P)(n, N)(n, G)$ \\
\hline $35 \mathrm{Br} 82$ & $(n, X \backslash P)(n, X \backslash A)(n, N 3 H E$ A PT) $(n, P)(n, N)(n, G)$ \\
\hline $36 \mathrm{Kr} 76$ & $(n, X \backslash P)(n, X \backslash A)(n, 2 A)(n, N 3 H E$ A PT NPD) $(n, N 3 H E A$ PT) $(n, P)(n, P)(n, G)$ \\
\hline $36 \mathrm{Kr} 79$ & $(n, X \backslash P)(n, X \backslash A)(n, 2 A)(n, N 3 H E$ A PT NPD) $(n, P)(n, P)(n, N)(n, G)$ \\
\hline $36 \mathrm{Kr} 81$ & $(\mathrm{n}, \mathrm{X} \backslash \mathrm{P})(\mathrm{n}, \mathrm{X} \backslash \mathrm{A})(\mathrm{n}, \mathrm{N} 3 \mathrm{HE}$ A PT) $(\mathrm{n}, \mathrm{P})(\mathrm{n}, \mathrm{G})$ \\
\hline $37 \mathrm{Rb} 82 \mathrm{~m} 1$ & $(n, X \backslash P)(n, X \backslash A)(n, 2 A)(n, N 3 H E$ A PT NPD) $(n, N 3 H E$ A PT NPD) $(n, P)(n, G)$ \\
\hline $37 \mathrm{Rb} 83$ & $(n, X \backslash P)(n, X \backslash A)(n, N 3 H E$ A PT) $(n, N 3 H E$ A PT) $(n, P)(n, P)(n, G)(n, G)$ \\
\hline $37 \mathrm{Rb} 84$ & $(\mathrm{n}, \mathrm{X} \backslash \mathrm{P})(\mathrm{n}, \mathrm{X} \backslash \mathrm{A})(\mathrm{n}, \mathrm{N} 3 \mathrm{HE}$ A PT) $(\mathrm{n}, \mathrm{P})(\mathrm{n}, \mathrm{G})$ \\
\hline $38 \mathrm{Sr} 82$ & $(n, X \backslash P)(n, X \backslash A)(n, N 3 H E$ A PT) $(n, N 3 H E$ A PT) $(n, P)(n, P)(n, G)(n, G)$ \\
\hline $38 \mathrm{Sr} 83$ & $(n, X \backslash P)(n, X \backslash A)(n, 2 A)(n, N 3 H E$ A PT NPD 2N2P) $(n, P)(n, G)$ \\
\hline $38 \mathrm{Sr} 85$ & $(n, X \backslash P)(n, X \backslash A)(n, N 3 H E A$ PT) $(n, P)(n, G)$ \\
\hline $38 \mathrm{Sr} 91$ & $(n, X \backslash A)(n, N 3 H E A)(n, G)$ \\
\hline $39 Y 86$ & $(n, X \backslash P)(n, X \backslash A)(n, N 3 H E$ A PT NPD) $(n, P)(n, G)(n, G)$ \\
\hline $39 Y 87$ & $(n, X \backslash P)(n, X \backslash A)(n, N 3 H E$ A PT) $(n, N 3 H E$ A PT) $(n, P)(n, P)(n, G)$ \\
\hline $39 Y 87 \mathrm{~m} 1$ & $(n, X \backslash P)(n, X \backslash A)(n, N 3 H E$ A PT) $(n, N 3 H E$ A PT) $(n, P)(n, P)(n, N)(n, G)$ \\
\hline $39 Y 88$ & $(n, X \backslash P)(n, X \backslash A)(n, N 3 H E$ A PT) $(n, P)(n, G)(n, G)$ \\
\hline $39 Y 93$ & $(n, X \backslash A)(n, N 3 H E A)(n, A)(n, G)$ \\
\hline $40 \mathrm{Zr} 86$ & $(n, X \backslash P)(n, X \backslash A)(n, 2 A)(n, N 3 H E$ A PT) $(n, N 3 H E A$ PT $)(n, P)(n, P)(n, G)(n, G)$ \\
\hline $40 \mathrm{Zr} 88$ & $(n, X \backslash P)(n, X \backslash A)(n, N 3 H E$ A PT) $(n, N 3 H E$ A PT) $(n, P)(n, G)(n, G)$ \\
\hline $40 \mathrm{Zr} 89$ & $(n, X \backslash P)(n, X \backslash A)(n, N 3 H E$ A PT) $(n, P)(n, P)(n, G)(n, G)$ \\
\hline $40 \mathrm{Zr} 97$ & $(n, X \backslash A)(n, N 3 H E A)(n, G)$ \\
\hline $41 \mathrm{Nb} 90$ & $\begin{array}{l}(\mathrm{n}, \mathrm{X} \backslash \mathrm{P})(\mathrm{n}, \mathrm{X} \backslash \mathrm{A})(\mathrm{n}, \mathrm{PA})(\mathrm{n}, \mathrm{N} 3 \mathrm{HE} \text { A PT NPD) (n,N3HE A PT NPD) }(\mathrm{n}, \mathrm{P})(\mathrm{n}, \mathrm{P})(\mathrm{n}, \mathrm{N}) \\
(\mathrm{n}, \mathrm{G})\end{array}$ \\
\hline $41 \mathrm{Nb} 91$ & $(n, X \backslash P)(n, X \backslash A)(n, N 3 H E A$ PT $)(n, P)(n, N)(n, G)(n, G)$ \\
\hline $41 \mathrm{Nb} 91 \mathrm{~m} 1$ & $(n, X \backslash P)(n, X \backslash A)(n, N 3 H E A$ PT $)(n, P)(n, N)(n, G)(n, G)$ \\
\hline $41 \mathrm{Nb} 92$ & $\begin{array}{l}(n, X \backslash P)(n, X \backslash A)(n, P A)(n, N 3 H E \text { A PT NPD) }(n, N 3 H E \text { A PT NPD) }(n, P)(n, N)(n, G) \\
(n, G)\end{array}$ \\
\hline $41 \mathrm{Nb} 92 \mathrm{~m} 1$ & $\begin{array}{l}(n, X \backslash P)(n, X \backslash A)(n, P A)(n, N 3 H E \text { A PT NPD 2N2P) (n,N3HE A PT NPD) }(n, P)(n, N) \\
(n, G)(n, G)\end{array}$ \\
\hline $41 \mathrm{Nb} 93 \mathrm{~m} 1$ & $(\mathrm{n}, \mathrm{X} \backslash \mathrm{P})(\mathrm{n}, \mathrm{X} \backslash \mathrm{A})(\mathrm{n}, \mathrm{N} 3 \mathrm{HE}$ A PT) $(\mathrm{n}, \mathrm{N} 3 \mathrm{HE}$ A PT) $(\mathrm{n}, \mathrm{P})(\mathrm{n}, \mathrm{N})(\mathrm{n}, \mathrm{G})(\mathrm{n}, \mathrm{G})$ \\
\hline $41 \mathrm{Nb} 95 \mathrm{~m} 1$ & $(n, X \backslash P)(n, X \backslash A)(n, N 3 H E A$ PT) $(n, P)(n, N)(n, G)$ \\
\hline $41 \mathrm{Nb} 96$ & $(n, X \backslash P)(n, X \backslash A)(n, N 3 H E$ A PT) $(n, N 3 H E$ A PT $)(n, P)(n, G)(n, G)$ \\
\hline 42Mo93 & $(n, X \backslash P)(n, X \backslash A)(n, P A)(n, N 3 H E$ A PT NPD 2N2P) $(n, N 3 H E$ A PT) $(n, P)(n, P)(n, G)$ \\
\hline $42 \mathrm{Mo} 93 \mathrm{~m} 1$ & $\begin{array}{l}(\mathrm{n}, \mathrm{X} \backslash \mathrm{P})(\mathrm{n}, \mathrm{X} \backslash \mathrm{A})(\mathrm{n}, \mathrm{PA})(\mathrm{n}, \mathrm{PA})(\mathrm{n}, \mathrm{N} 3 \mathrm{HE} \text { A PT NPD 2N2P) (n,N3HE A PT NPD 2N2P) } \\
(\mathrm{n}, \mathrm{P})(\mathrm{n}, \mathrm{P})(\mathrm{n}, \mathrm{G})\end{array}$ \\
\hline $43 \mathrm{Tc} 95$ & $(n, X \backslash P)(n, X \backslash A)(n, P A)(n, N 3 H E$ A PT NPD) $(n, N 3 H E A P T)(n, P)(n, N)(n, G)(n, G)$ \\
\hline $43 \mathrm{Tc} 95 \mathrm{~m} 1$ & $(n, X \backslash P)(n, X \backslash A)(n, P A)(n, N 3 H E$ A PT NPD) $(n, N 3 H E A$ PT $)(n, P)(n, N)(n, G)(n, G)$ \\
\hline $43 \mathrm{Tc} 96$ & $\begin{array}{l}(n, X \backslash P)(n, X \backslash A)(n, 2 A)(n, 2 A)(n, P A)(n, N 3 H E \text { A PT NPD) }(n, N 3 H E \text { A PT NPD) }(n, P) \\
(n, N)(n, G)(n, G)\end{array}$ \\
\hline $43 \mathrm{Tc} 97$ & $(n, X \backslash P)(n, X \backslash A)(n, 2 A)(n, 2 A)(n, N 3 H E$ A PT) $(n, N 3 H E A P T)(n, P)(n, N)(n, G)$ \\
\hline $43 \mathrm{Tc} 97 \mathrm{~m} 1$ & $(n, X \backslash P)(n, X \backslash A)(n, 2 A)(n, N 3 H E$ A PT) $(n, N 3 H E$ A PT) $(n, P)(n, N)(n, G)$ \\
\hline
\end{tabular}




\begin{tabular}{|c|c|}
\hline Target Nucl. & Reactions \\
\hline $43 \mathrm{Tc} 98$ & $(\mathrm{n}, \mathrm{X} \backslash \mathrm{P})(\mathrm{n}, \mathrm{X} \backslash \mathrm{A})(\mathrm{n}, 2 \mathrm{~A})(\mathrm{n}, 2 \mathrm{~A})(\mathrm{n}, \mathrm{N} 3 \mathrm{HE}$ A PT) $(\mathrm{n}, \mathrm{N} 3 \mathrm{HE}$ A PT) $(\mathrm{n}, \mathrm{P})(\mathrm{n}, \mathrm{G})(\mathrm{n}, \mathrm{G})$ \\
\hline $43 \mathrm{Tc} 99 \mathrm{~m} 1$ & $(\mathrm{n}, \mathrm{X} \backslash \mathrm{P})(\mathrm{n}, \mathrm{X} \backslash \mathrm{A})(\mathrm{n}, \mathrm{N} 3 \mathrm{HE}$ A PT) $(\mathrm{n}, \mathrm{G})$ \\
\hline $44 \mathrm{Ru} 97$ & $(n, X \backslash P)(n, X \backslash A)(n, 2 A)(n, 2 A)(n, N 3 H E$ A PT NPD 2N2P) $(n, P)(n, P)(n, G)$ \\
\hline $45 \mathrm{Rh} 99$ & $\begin{array}{l}(\mathrm{n}, \mathrm{X} \backslash \mathrm{P})(\mathrm{n}, \mathrm{X} \backslash \mathrm{A})(\mathrm{n}, 2 \mathrm{~A})(\mathrm{n}, 2 \mathrm{~A})(\mathrm{n}, \mathrm{PA})(\mathrm{n}, \mathrm{N} 3 \mathrm{HE} \text { A PT NPD) }(\mathrm{n}, \mathrm{N} 3 \mathrm{HE} \text { A PT) }(\mathrm{n}, \mathrm{P})(\mathrm{n}, \mathrm{N}) \\
(\mathrm{n}, \mathrm{G})(\mathrm{n}, \mathrm{G})\end{array}$ \\
\hline $45 \mathrm{Rh} 99 \mathrm{~m} 1$ & $\begin{array}{l}(\mathrm{n}, \mathrm{X} \backslash \mathrm{P})(\mathrm{n}, \mathrm{X} \backslash \mathrm{A})(\mathrm{n}, 2 \mathrm{~A})(\mathrm{n}, 2 \mathrm{~A})(\mathrm{n}, \mathrm{PA})(\mathrm{n}, \mathrm{N} 3 \mathrm{HE} \text { A PT NPD) (n,N3HE A PT) }(\mathrm{n}, \mathrm{P})(\mathrm{n}, \mathrm{N}) \\
(\mathrm{n}, \mathrm{G})(\mathrm{n}, \mathrm{G})\end{array}$ \\
\hline $45 \mathrm{Rh} 100$ & $\begin{array}{l}(\mathrm{n}, \mathrm{X} \backslash \mathrm{P})(\mathrm{n}, \mathrm{X} \backslash \mathrm{A})(\mathrm{n}, 2 \mathrm{~A})(\mathrm{n}, 2 \mathrm{~A})(\mathrm{n}, \mathrm{PA})(\mathrm{n}, \mathrm{N} 3 \mathrm{HE} \text { A PT NPD) (n,N3HE A PT NPD) (n,P) } \\
(\mathrm{n}, \mathrm{N})(\mathrm{n}, \mathrm{G})(\mathrm{n}, \mathrm{G})\end{array}$ \\
\hline 45Rh101 & $(n, X \backslash P)(n, X \backslash A)(n, N 3 H E A$ PT $)(n, P)(n, N)(n, G)(n, G)$ \\
\hline $45 \mathrm{Rh} 101 \mathrm{~m} 1$ & $(n, X \backslash P)(n, X \backslash A)(n, 2 A)(n, 2 A)(n, N 3 H E A$ PT $)(n, P)(n, N)(n, G)(n, G)$ \\
\hline $45 \mathrm{Rh} 102$ & $(n, X \backslash P)(n, X \backslash A)(n, 2 A)(n, 2 A)(n, N 3 H E$ A PT) $(n, N 3 H E A P T)(n, P)(n, N)(n, G)(n, G)$ \\
\hline $45 \mathrm{Rh} 102 \mathrm{~m} 1$ & $(\mathrm{n}, \mathrm{X} \backslash \mathrm{P})(\mathrm{n}, \mathrm{X} \backslash \mathrm{A})(\mathrm{n}, 2 \mathrm{~A})(\mathrm{n}, 2 \mathrm{~A})(\mathrm{n}, \mathrm{N} 3 \mathrm{HE}$ A PT) $(\mathrm{n}, \mathrm{N} 3 \mathrm{HE}$ A PT) $(\mathrm{n}, \mathrm{P})(\mathrm{n}, \mathrm{N})(\mathrm{n}, \mathrm{G})(\mathrm{n}, \mathrm{G})$ \\
\hline $46 \mathrm{Pd} 100$ & $(\mathrm{n}, \mathrm{X} \backslash \mathrm{P})(\mathrm{n}, \mathrm{X} \backslash \mathrm{A})(\mathrm{n}, 2 \mathrm{~A})(\mathrm{n}, 2 \mathrm{~A})(\mathrm{n}, \mathrm{N} 3 \mathrm{HE}$ A PT NPD) $(\mathrm{n}, \mathrm{P})(\mathrm{n}, \mathrm{P})(\mathrm{n}, \mathrm{G})$ \\
\hline $46 \mathrm{Pd} 101$ & $(n, X \backslash P)(n, X \backslash A)(n, 2 A)(n, P A)(n, P A)(n, N 3 H E$ A PT NPD 2N2P) $(n, P)(n, P)(n, G)$ \\
\hline $46 \mathrm{Pd} 103$ & $(\mathrm{n}, \mathrm{X} \backslash \mathrm{P})(\mathrm{n}, \mathrm{X} \backslash \mathrm{A})(\mathrm{n}, 2 \mathrm{~A})(\mathrm{n}, \mathrm{N} 3 \mathrm{HE}$ A PT NPD) $(\mathrm{n}, \mathrm{P})(\mathrm{n}, \mathrm{P})(\mathrm{n}, \mathrm{G})$ \\
\hline $46 \mathrm{Pd} 109$ & $(n, X \backslash A)(n, N 3 H E A$ PT) $(n, G)$ \\
\hline $46 \mathrm{Pd} 112$ & $(\mathrm{n}, \mathrm{X} \backslash \mathrm{A})(\mathrm{n}, \mathrm{A})(\mathrm{n}, \mathrm{G})(\mathrm{n}, \mathrm{G})$ \\
\hline $47 \mathrm{Ag} 105$ & $(n, X \backslash P)(n, X \backslash A)(n, N 3 H E$ A PT) $(n, N 3 H E$ A PT) $(n, P)(n, N)(n, G)(n, G)$ \\
\hline 47Ag106m1 & $\begin{array}{l}(\mathrm{n}, \mathrm{X} \backslash \mathrm{P})(\mathrm{n}, \mathrm{X} \backslash \mathrm{A})(\mathrm{n}, 2 \mathrm{~A})(\mathrm{n}, 2 \mathrm{~A})(\mathrm{n}, \mathrm{PA})(\mathrm{n}, \mathrm{N} 3 \mathrm{HE} \text { A PT) }(\mathrm{n}, \mathrm{N} 3 \mathrm{HE} \mathrm{A} P \mathrm{PT})(\mathrm{n}, \mathrm{P})(\mathrm{n}, \mathrm{N})(\mathrm{n}, \mathrm{G}) \\
(\mathrm{n}, \mathrm{G})\end{array}$ \\
\hline $47 \mathrm{Ag} 108 \mathrm{~m} 1$ & $(n, X \backslash P)(n, X \backslash A)(n, N 3 H E$ A PT) $(n, N 3 H E$ A PT) $(n, P)(n, N)(n, G)(n, G)$ \\
\hline $48 \mathrm{Cd} 107$ & $(\mathrm{n}, \mathrm{X} \backslash \mathrm{P})(\mathrm{n}, \mathrm{X} \backslash \mathrm{A})(\mathrm{n}, 2 \mathrm{~A})(\mathrm{n}, \mathrm{N} 3 \mathrm{HE}$ A PT NPD 2N2P) $(\mathrm{n}, \mathrm{P})(\mathrm{n}, \mathrm{P})(\mathrm{n}, \mathrm{G})$ \\
\hline $48 \mathrm{Cd} 109$ & $(n, X \backslash P)(n, X \backslash A)(n, 2 A)(n, N 3 H E$ A PT NPD) $(n, P)(n, P)(n, G)$ \\
\hline $48 \mathrm{Cd} 113 \mathrm{~m} 1$ & $(n, X \backslash A)(n, N 3 H E$ A PT) $(n, N)(n, G)$ \\
\hline $48 \mathrm{Cd} 115$ & $(n, X \backslash A)(n, N 3 H E A)(n, G)$ \\
\hline 49In111 & $(n, X \backslash P)(n, X \backslash A)(n, N 3 H E$ A PT) $(n, N 3 H E$ A PT) $(n, P)(n, P)(n, G)$ \\
\hline $49 \operatorname{In} 114 \mathrm{~m} 1$ & $(n, X \backslash P)(n, X \backslash A)(n, N 3 H E$ A PT) $(n, N 3 H E$ A PT $)(n, P)(n, N)(n, G)(n, G)$ \\
\hline $50 \mathrm{Sn} 117 \mathrm{~m} 1$ & $(\mathrm{n}, \mathrm{X} \backslash \mathrm{P})(\mathrm{n}, \mathrm{X} \backslash \mathrm{A})(\mathrm{n}, \mathrm{N} 3 \mathrm{HE}$ A PT) $(\mathrm{n}, \mathrm{N})(\mathrm{n}, \mathrm{G})$ \\
\hline $50 \mathrm{Sn} 119 \mathrm{~m} 1$ & $(n, X \backslash A)(n, N 3 H E$ A PT) $(n, N)(n, G)$ \\
\hline $50 \mathrm{Sn} 121$ & $(n, X \backslash A)(n, N 3 H E A)(n, N)(n, G)$ \\
\hline $50 \mathrm{Sn} 121 \mathrm{~m} 1$ & $(n, X \backslash A)(n, N 3 H E A)(n, N)(n, G)$ \\
\hline $51 \mathrm{Sb} 119$ & $(n, X \backslash P)(n, X \backslash A)(n, N 3 H E$ A PT) $(n, N 3 H E$ A PT) $(n, N 3 H E$ A PT) $(n, P)(n, P)(n, G)(n, G)$ \\
\hline $51 \mathrm{Sb} 120 \mathrm{~m} 1$ & $(n, X \backslash P)(n, X \backslash A)(n, N 3 H E$ A PT) $(n, N 3 H E$ A PT) $(n, P)(n, N)(n, G)$ \\
\hline $51 \mathrm{Sb} 122$ & $(n, X \backslash P)(n, X \backslash A)(n, N 3 H E A$ PT) $(n, N 3 H E$ A PT) $(n, P)(n, N)(n, G)$ \\
\hline $51 \mathrm{Sb} 127$ & $(\mathrm{n}, \mathrm{X} \backslash \mathrm{A})(\mathrm{n}, \mathrm{G})(\mathrm{n}, \mathrm{G})$ \\
\hline $51 \mathrm{Sb} 128$ & $(n, X \backslash P)(n, X \backslash A)(n, A)(n, A)(n, P)(n, G)(n, G)$ \\
\hline $52 \mathrm{Te} 118$ & $(\mathrm{n}, \mathrm{X} \backslash \mathrm{P})(\mathrm{n}, \mathrm{X} \backslash \mathrm{A})(\mathrm{n}, 2 \mathrm{~A})(\mathrm{n}, 2 \mathrm{~A})(\mathrm{n}, \mathrm{NA})(\mathrm{n}, \mathrm{N} 3 \mathrm{HE}$ A PT NPD) $(\mathrm{n}, \mathrm{P})(\mathrm{n}, \mathrm{P})(\mathrm{n}, \mathrm{G})(\mathrm{n}, \mathrm{G})$ \\
\hline $52 \mathrm{Te} 119$ & $\begin{array}{l}(\mathrm{n}, \mathrm{X} \backslash \mathrm{P})(\mathrm{n}, \mathrm{X} \backslash \mathrm{A})(\mathrm{n}, 2 \mathrm{~A})(\mathrm{n}, \mathrm{PA})(\mathrm{n}, \mathrm{PA})(\mathrm{n}, \mathrm{NA})(\mathrm{n}, \mathrm{N} 3 \mathrm{HE} \text { A PT NPD 2N2P) (n,P) (n,P) } \\
(\mathrm{n}, \mathrm{G})\end{array}$ \\
\hline $52 \mathrm{Te} 119 \mathrm{~m} 1$ & $(n, X \backslash P)(n, X \backslash A)(n, 2 A)(n, P A)(n, P A)(n, N A)(n, N 3 H E$ A PT NPD 2N2P) $(n, P)(n, P)$ \\
\hline
\end{tabular}




\begin{tabular}{|c|c|}
\hline Target Nucl. & Reactions \\
\hline & $(\mathrm{n}, \mathrm{N})(\mathrm{n}, \mathrm{G})$ \\
\hline $52 \mathrm{Te} 121$ & $(n, X \backslash P)(n, X \backslash A)(n, N 3 H E$ A PT NPD 2N2P) $(n, P)(n, G)$ \\
\hline $52 \mathrm{Te} 121 \mathrm{~m} 1$ & $(n, X \backslash P)(n, X \backslash A)(n, N 3 H E$ A PT NPD 2N2P) $(n, P)(n, N)(n, G)$ \\
\hline $52 \mathrm{Te} 123 \mathrm{~m} 1$ & $(n, X \backslash P)(n, X \backslash A)(n, N 3 H E$ A PT NPD) $(n, P)(n, N)(n, G)$ \\
\hline $52 \mathrm{Te} 125 \mathrm{~m} 1$ & $(n, X \backslash P)(n, X \backslash A)(n, N 3 H E A P T)(n, P)(n, N)(n, G)$ \\
\hline $52 \mathrm{Te} 127$ & $(n, X \backslash P)(n, X \backslash A)(n, N 3 H E A)(n, N)(n, G)$ \\
\hline $52 \mathrm{Te} 129$ & $(n, X \backslash A)(n, N 3 H E A)(n, N)(n, G)$ \\
\hline $52 \mathrm{Te} 131 \mathrm{~m} 1$ & $(n, X \backslash A)(n, N 3 H E A)(n, A)(n, N)(n, G)$ \\
\hline $53 \mathrm{I} 123$ & $(\mathrm{n}, \mathrm{X} \backslash \mathrm{P})(\mathrm{n}, \mathrm{X} \backslash \mathrm{A})(\mathrm{n}, \mathrm{PA})(\mathrm{n}, \mathrm{PA})(\mathrm{n}, \mathrm{N} 3 \mathrm{HE}$ A PT) $(\mathrm{n}, \mathrm{N} 3 \mathrm{HE}$ A PT) $(\mathrm{n}, \mathrm{P})(\mathrm{n}, \mathrm{P})(\mathrm{n}, \mathrm{G})$ \\
\hline $53 \mathrm{I} 124$ & $(n, X \backslash P)(n, X \backslash A)(n, P A)(n, N 3 H E A$ PT) $(n, P)(n, G)$ \\
\hline $53 \mathrm{I} 125$ & $(n, X \backslash P)(n, X \backslash A)(n, N 3 H E$ A PT) (n,N3HE A PT) $(n, P)(n, P)(n, G)$ \\
\hline $53 \mathrm{I} 126$ & $(\mathrm{n}, \mathrm{X} \backslash \mathrm{P})(\mathrm{n}, \mathrm{X} \backslash \mathrm{A})(\mathrm{n}, \mathrm{PA})(\mathrm{n}, \mathrm{N} 3 \mathrm{HE} \mathrm{A} \mathrm{PT})(\mathrm{n}, \mathrm{P})(\mathrm{n}, \mathrm{G})$ \\
\hline $53 \mathrm{I} 128$ & $(n, X \backslash P)(n, X \backslash A)(n, N 3 H E A$ PT) $(n, P)(n, G)$ \\
\hline $53 \mathrm{I} 133$ & $(\mathrm{n}, \mathrm{X} \backslash \mathrm{A})(\mathrm{n}, \mathrm{A})(\mathrm{n}, \mathrm{A})(\mathrm{n}, \mathrm{G})(\mathrm{n}, \mathrm{G})$ \\
\hline $54 \mathrm{Xe} 122$ & $\begin{array}{l}(\mathrm{n}, \mathrm{X} \backslash \mathrm{P})(\mathrm{n}, \mathrm{X} \backslash \mathrm{A})(\mathrm{n}, 2 \mathrm{~A})(\mathrm{n}, \mathrm{PA})(\mathrm{n}, \mathrm{PA})(\mathrm{n}, \mathrm{NA})(\mathrm{n}, \mathrm{N} 3 \mathrm{HE} \text { A PT NPD) (n,N3HE A PT } \\
\mathrm{NPD})(\mathrm{n}, \mathrm{P})(\mathrm{n}, \mathrm{G})\end{array}$ \\
\hline $54 \mathrm{Xe} 125$ & $(n, X \backslash P)(n, X \backslash A)(n, 2 A)(n, P A)(n, N 3 H E$ A PT NPD 2N2P) $(n, P)(n, G)$ \\
\hline $54 \mathrm{Xe} 127$ & $(\mathrm{n}, \mathrm{X} \backslash \mathrm{P})(\mathrm{n}, \mathrm{X} \backslash \mathrm{A})(\mathrm{n}, 2 \mathrm{~A})(\mathrm{n}, \mathrm{N} 3 \mathrm{HE}$ A PT) $(\mathrm{n}, \mathrm{P})(\mathrm{n}, \mathrm{G})$ \\
\hline $54 \mathrm{Xe} 129 \mathrm{~m} 1$ & $(n, X \backslash P)(n, X \backslash A)(n, N 3 H E$ A PT) $(n, P)(n, N)(n, G)$ \\
\hline $54 \mathrm{Xe} 131 \mathrm{~m} 1$ & $(n, X \backslash P)(n, X \backslash A)(n, N 3 H E$ A PT) $(n, P)(n, N)(n, G)$ \\
\hline $54 \mathrm{Xe} 133 \mathrm{~m} 1$ & $(n, X \backslash P)(n, X \backslash A)(n, N 3 H E A)(n, N)(n, G)(n, G)$ \\
\hline $55 \mathrm{Cs} 127$ & $(\mathrm{n}, \mathrm{X} \backslash \mathrm{P})(\mathrm{n}, \mathrm{X} \backslash \mathrm{A})(\mathrm{n}, 2 \mathrm{~A})(\mathrm{n}, \mathrm{PA})(\mathrm{n}, \mathrm{PA})(\mathrm{n}, \mathrm{N} 3 \mathrm{HE} \mathrm{A} \mathrm{PT})(\mathrm{n}, \mathrm{P})(\mathrm{n}, \mathrm{P})(\mathrm{n}, \mathrm{G})$ \\
\hline $55 \mathrm{Cs} 129$ & $(\mathrm{n}, \mathrm{X} \backslash \mathrm{P})(\mathrm{n}, \mathrm{X} \backslash \mathrm{A})(\mathrm{n}, \mathrm{PA})(\mathrm{n}, \mathrm{N} 3 \mathrm{HE}$ A PT) $(\mathrm{n}, \mathrm{P})(\mathrm{n}, \mathrm{P})(\mathrm{n}, \mathrm{G})(\mathrm{n}, \mathrm{G})$ \\
\hline $55 \mathrm{Cs} 131$ & $(\mathrm{n}, \mathrm{X} \backslash \mathrm{P})(\mathrm{n}, \mathrm{X} \backslash \mathrm{A})(\mathrm{n}, \mathrm{N} 3 \mathrm{HE}$ A PT) $(\mathrm{n}, \mathrm{P})(\mathrm{n}, \mathrm{P})(\mathrm{n}, \mathrm{G})$ \\
\hline $55 \mathrm{Cs} 132$ & $(n, X \backslash P)(n, X \backslash A)(n, N 3 H E A$ PT) $(n, P)(n, G)$ \\
\hline $56 \mathrm{Ba} 128$ & $(\mathrm{n}, \mathrm{X} \backslash \mathrm{P})(\mathrm{n}, \mathrm{X} \backslash \mathrm{A})(\mathrm{n}, 2 \mathrm{~A})(\mathrm{n}, 2 \mathrm{~A})(\mathrm{n}, \mathrm{PA})(\mathrm{n}, \mathrm{N} 3 \mathrm{HE}$ A PT) $(\mathrm{n}, \mathrm{N} 3 \mathrm{HE}$ A PT) $(\mathrm{n}, \mathrm{P})(\mathrm{n}, \mathrm{G})(\mathrm{n}, \mathrm{G})$ \\
\hline $56 \mathrm{Ba} 129$ & $(n, X \backslash P)(n, X \backslash A)(n, 2 A)(n, P A)(n, N 3 H E$ A PT NPD 2N2P) $(n, P)(n, N)(n, G)$ \\
\hline $56 \mathrm{Ba} 131$ & $(n, X \backslash P)(n, X \backslash A)(n, 2 A)(n, P A)(n, N A)(n, N 3 H E A$ PT NPD) $(n, P)(n, G)$ \\
\hline $56 \mathrm{Ba} 133 \mathrm{~m} 1$ & $(n, X \backslash P)(n, X \backslash A)(n, N 3 H E$ A PT NPD) $(n, P)(n, N)(n, G)$ \\
\hline $56 \mathrm{Ba} 135 \mathrm{~m} 1$ & $(n, X \backslash P)(n, X \backslash A)(n, N 3 H E A P T)(n, P)(n, N)(n, G)(n, G)$ \\
\hline $56 \mathrm{Ba} 139$ & $(\mathrm{n}, \mathrm{X} \backslash \mathrm{A})(\mathrm{n}, \mathrm{NA})(\mathrm{n}, \mathrm{N} 3 \mathrm{HE} \mathrm{A})(\mathrm{n}, \mathrm{G})$ \\
\hline $57 \mathrm{La135}$ & $(\mathrm{n}, \mathrm{X} \backslash \mathrm{P})(\mathrm{n}, \mathrm{X} \backslash \mathrm{A})(\mathrm{n}, \mathrm{N} 3 \mathrm{HE}$ A PT) $(\mathrm{n}, \mathrm{P})(\mathrm{n}, \mathrm{P})(\mathrm{n}, \mathrm{G})(\mathrm{n}, \mathrm{G})$ \\
\hline 57La137 & $(n, X \backslash P)(n, X \backslash A)(n, N 3 H E$ A PT) $(n, N 3 H E$ A PT) $(n, P)(n, P)(n, G)$ \\
\hline 57La141 & $(\mathrm{n}, \mathrm{X} \backslash \mathrm{A})(\mathrm{n}, \mathrm{NA})(\mathrm{n}, \mathrm{N} 3 \mathrm{HE} \mathrm{A})(\mathrm{n}, \mathrm{N} 3 \mathrm{HE} \mathrm{A})(\mathrm{n}, \mathrm{G})$ \\
\hline $58 \mathrm{Ce} 134$ & $\begin{array}{l}(\mathrm{n}, \mathrm{X} \backslash \mathrm{P})(\mathrm{n}, \mathrm{X} \backslash \mathrm{A})(\mathrm{n}, 2 \mathrm{~A})(\mathrm{n}, 2 \mathrm{~A})(\mathrm{n}, \mathrm{PA})(\mathrm{n}, \mathrm{PA})(\mathrm{n}, \mathrm{NA})(\mathrm{n}, \mathrm{N} 3 \mathrm{HE} \text { A PT) (n,N3HE A PT) } \\
(\mathrm{n}, \mathrm{P})(\mathrm{n}, \mathrm{G})(\mathrm{n}, \mathrm{G})\end{array}$ \\
\hline $58 \mathrm{Ce} 135$ & $(\mathrm{n}, \mathrm{X} \backslash \mathrm{P})(\mathrm{n}, \mathrm{X} \backslash \mathrm{A})(\mathrm{n}, 2 \mathrm{~A})(\mathrm{n}, \mathrm{PA})(\mathrm{n}, \mathrm{N} 3 \mathrm{HE}$ A PT NPD 2N2P) $(\mathrm{n}, \mathrm{P})(\mathrm{n}, \mathrm{G})$ \\
\hline $58 \mathrm{Ce} 137$ & $(\mathrm{n}, \mathrm{X} \backslash \mathrm{P})(\mathrm{n}, \mathrm{X} \backslash \mathrm{A})(\mathrm{n}, 2 \mathrm{~A})(\mathrm{n}, \mathrm{PA})(\mathrm{n}, \mathrm{NA})(\mathrm{n}, \mathrm{NA})(\mathrm{n}, \mathrm{N} 3 \mathrm{HE}$ A PT NPD) $(\mathrm{n}, \mathrm{P})(\mathrm{n}, \mathrm{G})$ \\
\hline $58 \mathrm{Ce} 137 \mathrm{~m} 1$ & $(n, X \backslash P)(n, X \backslash A)(n, 2 A)(n, P A)(n, N 3 H E A$ PT NPD) $(n, P)(n, N)(n, G)$ \\
\hline
\end{tabular}




\begin{tabular}{|c|c|}
\hline Target Nucl. & Reactions \\
\hline $60 \mathrm{Nd} 140$ & $(n, X \backslash P)(n, X \backslash A)(n, 2 A)(n, P A)(n, P A)(n, N 3 H E A$ PT) $(n, N 3 H E$ A PT) $(n, P)(n, G)(n, G)$ \\
\hline $60 \mathrm{Nd} 141$ & $(\mathrm{n}, \mathrm{X} \backslash \mathrm{P})(\mathrm{n}, \mathrm{X} \backslash \mathrm{A})(\mathrm{n}, 2 \mathrm{~A})(\mathrm{n}, \mathrm{PA})(\mathrm{n}, \mathrm{NA})(\mathrm{n}, \mathrm{N} 3 \mathrm{HE}$ A PT NPD) $(\mathrm{n}, \mathrm{P})(\mathrm{n}, \mathrm{G})$ \\
\hline $60 \mathrm{Nd} 149$ & $(\mathrm{n}, \mathrm{X} \backslash \mathrm{A})(\mathrm{n}, \mathrm{NA})(\mathrm{n}, \mathrm{N} 3 \mathrm{HE} \mathrm{A})(\mathrm{n}, \mathrm{G})$ \\
\hline $61 \mathrm{Pm} 143$ & $(\mathrm{n}, \mathrm{X} \backslash \mathrm{P})(\mathrm{n}, \mathrm{X} \backslash \mathrm{A})(\mathrm{n}, \mathrm{PA})(\mathrm{n}, \mathrm{PA})(\mathrm{n}, \mathrm{N} 3 \mathrm{HE}$ A PT) $(\mathrm{n}, \mathrm{P})(\mathrm{n}, \mathrm{G})$ \\
\hline $61 \mathrm{Pm} 144$ & $(n, X \backslash P)(n, X \backslash A)(n, 2 A)(n, P A)(n, N A)(n, N 3 H E$ A PT NPD 2N2P) $(n, P)(n, G)$ \\
\hline $61 \mathrm{Pm} 145$ & $\begin{array}{l}(\mathrm{n}, \mathrm{X} \backslash \mathrm{P})(\mathrm{n}, \mathrm{X} \backslash \mathrm{A})(\mathrm{n}, 2 \mathrm{~A})(\mathrm{n}, \mathrm{NPA})(\mathrm{n}, \mathrm{PA})(\mathrm{n}, \mathrm{NA})(\mathrm{n}, \mathrm{N} 3 \mathrm{HE} \mathrm{A} \text { PT) }(\mathrm{n}, \mathrm{N} 3 \mathrm{HE} \mathrm{A} \text { PT) }(\mathrm{n}, \mathrm{P}) \\
(\mathrm{n}, \mathrm{G})\end{array}$ \\
\hline $61 \mathrm{Pm} 146$ & $\begin{array}{l}(\mathrm{n}, \mathrm{X} \backslash \mathrm{P})(\mathrm{n}, \mathrm{X} \backslash \mathrm{A})(\mathrm{n}, 2 \mathrm{~A})(\mathrm{n}, \mathrm{NDA} 2 \mathrm{NPA})(\mathrm{n}, \mathrm{PA})(\mathrm{n}, \mathrm{NA})(\mathrm{n}, \mathrm{NA})(\mathrm{n}, \mathrm{N} 3 \mathrm{HE} \mathrm{A} P \mathrm{PT})(\mathrm{n}, \mathrm{P}) \\
(\mathrm{n}, \mathrm{G})\end{array}$ \\
\hline $61 \mathrm{Pm} 150$ & $(\mathrm{n}, \mathrm{X} \backslash \mathrm{P})(\mathrm{n}, \mathrm{X} \backslash \mathrm{A})(\mathrm{n}, \mathrm{NA})(\mathrm{n}, \mathrm{N} 3 \mathrm{HE} \mathrm{A})(\mathrm{n}, \mathrm{P})(\mathrm{n}, \mathrm{G})$ \\
\hline $62 \mathrm{Sm} 145$ & $(\mathrm{n}, \mathrm{X} \backslash \mathrm{P})(\mathrm{n}, \mathrm{X} \backslash \mathrm{A})(\mathrm{n}, 2 \mathrm{~A})(\mathrm{n}, \mathrm{PA})(\mathrm{n}, \mathrm{NA})(\mathrm{n}, \mathrm{NA})(\mathrm{n}, \mathrm{N} 3 \mathrm{HE}$ A PT NPD 2N2P) $(\mathrm{n}, \mathrm{P})(\mathrm{n}, \mathrm{G})$ \\
\hline $62 \mathrm{Sm} 146$ & $(\mathrm{n}, \mathrm{X} \backslash \mathrm{P})(\mathrm{n}, \mathrm{X} \backslash \mathrm{A})(\mathrm{n}, 2 \mathrm{~A})(\mathrm{n}, 2 \mathrm{~A})(\mathrm{n}, \mathrm{PA})(\mathrm{n}, \mathrm{PA})(\mathrm{n}, \mathrm{NA})(\mathrm{n}, \mathrm{N} 3 \mathrm{HE} \mathrm{A} \mathrm{PT})(\mathrm{n}, \mathrm{G})$ \\
\hline $62 \mathrm{Sm} 156$ & $(\mathrm{n}, \mathrm{X} \backslash \mathrm{A})(\mathrm{n}, \mathrm{N} 3 \mathrm{HE} \mathrm{A})(\mathrm{n}, \mathrm{G})$ \\
\hline $63 \mathrm{Eu} 145$ & $(\mathrm{n}, \mathrm{X} \backslash \mathrm{P})(\mathrm{n}, \mathrm{X} \backslash \mathrm{A})(\mathrm{n}, 2 \mathrm{~A})(\mathrm{n}, 2 \mathrm{~A})(\mathrm{n}, \mathrm{PA})(\mathrm{n}, \mathrm{PA})(\mathrm{n}, \mathrm{NA})(\mathrm{n}, \mathrm{N} 3 \mathrm{HE}$ A PT NPD) $(\mathrm{n}, \mathrm{P})(\mathrm{n}, \mathrm{G})$ \\
\hline $63 \mathrm{Eu} 146$ & $(n, X \backslash P)(n, X \backslash A)(n, 2 A)(n, P A)(n, N A)(n, N 3 H E$ A PT NPD 2N2P) $(n, P)(n, G)$ \\
\hline $63 \mathrm{Eu} 147$ & $(\mathrm{n}, \mathrm{X} \backslash \mathrm{P})(\mathrm{n}, \mathrm{X} \backslash \mathrm{A})(\mathrm{n}, 2 \mathrm{~A})(\mathrm{n}, \mathrm{PA})(\mathrm{n}, \mathrm{NA})(\mathrm{n}, \mathrm{N} 3 \mathrm{HE}$ A PT NPD) $(\mathrm{n}, \mathrm{P})(\mathrm{n}, \mathrm{G})$ \\
\hline $63 \mathrm{Eu} 148$ & $(n, X \backslash P)(n, X \backslash A)(n, 2 A)(n, P A)(n, N A)(n, N 3 H E$ A PT NPD 2N2P) $(n, P)(n, G)$ \\
\hline $63 \mathrm{Eu} 149$ & $\begin{array}{l}(\mathrm{n}, \mathrm{X} \backslash \mathrm{P})(\mathrm{n}, \mathrm{X} \backslash \mathrm{A})(\mathrm{n}, \mathrm{N} 2 \mathrm{~A})(\mathrm{n}, 2 \mathrm{~A})(\mathrm{n}, 2 \mathrm{~A})(\mathrm{n}, \mathrm{NPA})(\mathrm{n}, \mathrm{PA})(\mathrm{n}, \mathrm{NA})(\mathrm{n}, \mathrm{N} 3 \mathrm{HE} \mathrm{A} P \mathrm{PT})(\mathrm{n}, \mathrm{P}) \\
(\mathrm{n}, \mathrm{G})(\mathrm{n}, \mathrm{G})\end{array}$ \\
\hline $63 \mathrm{Eu} 150$ & $\begin{array}{l}(\mathrm{n}, \mathrm{X} \backslash \mathrm{P})(\mathrm{n}, \mathrm{X} \backslash \mathrm{A})(\mathrm{n}, 2 \mathrm{~A})(\mathrm{n}, \mathrm{NDA} 2 \mathrm{NPA})(\mathrm{n}, \mathrm{NPA})(\mathrm{n}, \mathrm{PA})(\mathrm{n}, \mathrm{NA})(\mathrm{n}, \mathrm{N} 3 \mathrm{HE} \mathrm{A} P \mathrm{PT})(\mathrm{n}, \mathrm{P}) \\
(\mathrm{n}, \mathrm{N})(\mathrm{n}, \mathrm{G})\end{array}$ \\
\hline $63 \mathrm{Eu} 150 \mathrm{~m} 1$ & $\begin{array}{l}(\mathrm{n}, \mathrm{X} \backslash \mathrm{P})(\mathrm{n}, \mathrm{X} \backslash \mathrm{A})(\mathrm{n}, 2 \mathrm{~A})(\mathrm{n}, \mathrm{NDA} 2 \mathrm{NPA})(\mathrm{n}, \mathrm{NPA})(\mathrm{n}, \mathrm{PA})(\mathrm{n}, \mathrm{NA})(\mathrm{n}, \mathrm{N} 3 \mathrm{HE} \mathrm{A} P \mathrm{PT})(\mathrm{n}, \mathrm{P}) \\
(\mathrm{n}, \mathrm{N})(\mathrm{n}, \mathrm{G})\end{array}$ \\
\hline $63 \mathrm{Eu} 152 \mathrm{~m} 1$ & $(n, X \backslash P)(n, X \backslash A)(n, P A)(n, N A)(n, N A)(n, N 3 H E A)(n, P)(n, N)(n, N)(n, G)$ \\
\hline $64 \mathrm{Gd} 146$ & $(\mathrm{n}, \mathrm{X} \backslash \mathrm{P})(\mathrm{n}, \mathrm{X} \backslash \mathrm{A})(\mathrm{n}, 2 \mathrm{~A})(\mathrm{n}, 2 \mathrm{~A})(\mathrm{n}, \mathrm{PA})(\mathrm{n}, \mathrm{NA})(\mathrm{n}, \mathrm{N} 3 \mathrm{HE}$ A PT NPD 2N2P) $(\mathrm{n}, \mathrm{P})(\mathrm{n}, \mathrm{G})$ \\
\hline $64 \mathrm{Gd} 147$ & $(n, X \backslash P)(n, X \backslash A)(n, 2 A)(n, 3 H E A)(n, P A)(n, N A)(n, N 3 H E$ A PT NPD 2N2P) $(n, P)(n, G)$ \\
\hline $64 \mathrm{Gd} 148$ & $\begin{array}{l}(\mathrm{n}, \mathrm{X} \backslash \mathrm{P})(\mathrm{n}, \mathrm{X} \backslash \mathrm{A})(\mathrm{n}, 2 \mathrm{~A})(\mathrm{n}, 2 \mathrm{~A})(\mathrm{n}, \mathrm{PA})(\mathrm{n}, \mathrm{NA} \mathrm{NPT})(\mathrm{n}, \mathrm{N} 3 \mathrm{HE} \text { A PT NPD 2N2P) (n,P) } \\
(\mathrm{n}, \mathrm{G})\end{array}$ \\
\hline $64 \mathrm{Gd} 149$ & $(n, X \backslash P)(n, X \backslash A)(n, 2 A)(n, P A)(n, N A)(n, N 3 H E$ A PT NPD 2N2P) $(n, P)(n, G)$ \\
\hline $64 \mathrm{Gd} 150$ & $(\mathrm{n}, \mathrm{X} \backslash \mathrm{P})(\mathrm{n}, \mathrm{X} \backslash \mathrm{A})(\mathrm{n}, \mathrm{N} 2 \mathrm{~A})(\mathrm{n}, 2 \mathrm{~A})(\mathrm{n}, \mathrm{PA})(\mathrm{n}, \mathrm{NA})(\mathrm{n}, \mathrm{N} 3 \mathrm{HE} \mathrm{A} \mathrm{PT})(\mathrm{n}, \mathrm{G})$ \\
\hline $64 \mathrm{Gd} 151$ & $(\mathrm{n}, \mathrm{X} \backslash \mathrm{P})(\mathrm{n}, \mathrm{X} \backslash \mathrm{A})(\mathrm{n}, \mathrm{N} 2 \mathrm{~A})(\mathrm{n}, 2 \mathrm{~A})(\mathrm{n}, \mathrm{PA})(\mathrm{n}, \mathrm{NA})(\mathrm{n}, \mathrm{N} 3 \mathrm{HE}$ A PT NPD 2N2P) $(\mathrm{n}, \mathrm{P})(\mathrm{n}, \mathrm{G})$ \\
\hline $64 \mathrm{Gd} 159$ & $(n, X \backslash A)(n, N 3 H E A)(n, G)$ \\
\hline $65 \mathrm{~Tb} 151$ & $\begin{array}{l}(\mathrm{n}, \mathrm{X} \backslash \mathrm{P})(\mathrm{n}, \mathrm{X} \backslash \mathrm{D})(\mathrm{n}, \mathrm{X} \backslash \mathrm{A})(\mathrm{n}, \mathrm{N} 2 \mathrm{~A})(\mathrm{n}, 2 \mathrm{~A})(\mathrm{n}, \mathrm{NDA} 2 \mathrm{NPA})(\mathrm{n}, \mathrm{DA})(\mathrm{n}, \mathrm{PA})(\mathrm{n}, \mathrm{NA}) \\
(\mathrm{n}, \mathrm{N} 3 \mathrm{HE} \text { A PT NPD 2N2P) }(\mathrm{n}, \mathrm{NP})(\mathrm{n}, \mathrm{P})(\mathrm{n}, \mathrm{N})(\mathrm{n}, \mathrm{G})(\mathrm{n}, \mathrm{G})\end{array}$ \\
\hline $65 \mathrm{~Tb} 152$ & $(\mathrm{n}, \mathrm{X} \backslash \mathrm{P})(\mathrm{n}, \mathrm{X} \backslash \mathrm{A})(\mathrm{n}, \mathrm{N} 2 \mathrm{~A})(\mathrm{n}, 2 \mathrm{~A})(\mathrm{n}, \mathrm{PA})(\mathrm{n}, \mathrm{NA})(\mathrm{n}, \mathrm{N} 3 \mathrm{HE}$ A PT NPD 2N2P) $(\mathrm{n}, \mathrm{P})(\mathrm{n}, \mathrm{G})$ \\
\hline $65 \mathrm{~Tb} 153$ & $\begin{array}{l}(n, X \backslash P)(n, X \backslash A)(n, N 2 A)(n, 2 A)(n, P A)(n, N A)(n, N 3 H E \text { A PT) }(n, N 3 H E A P T)(n, P) \\
(n, G)(n, G)(n, G)\end{array}$ \\
\hline $65 \mathrm{~Tb} 154$ & $\begin{array}{l}(\mathrm{n}, \mathrm{X} \backslash \mathrm{P})(\mathrm{n}, \mathrm{X} \backslash \mathrm{A})(\mathrm{n}, 2 \mathrm{~A})(\mathrm{n}, \mathrm{TA} \text { NDA 2NPA) }(\mathrm{n}, \mathrm{PA})(\mathrm{n}, \mathrm{NA})(\mathrm{n}, \mathrm{NA})(\mathrm{n}, \mathrm{N} 3 \mathrm{HE} \text { A PT) }(\mathrm{n}, \mathrm{P}) \\
(\mathrm{n}, \mathrm{G})\end{array}$ \\
\hline $65 \mathrm{~Tb} 154 \mathrm{~m} 1$ & $(n, X \backslash P)(n, X \backslash A)(n, 2 A)(n, N P A)(n, P A)(n, N A)(n, N A)(n, N 3 H E$ A PT NPD) $(n, P)(n, G)$ \\
\hline $65 \mathrm{~Tb} 154 \mathrm{~m} 2$ & $\begin{array}{l}(\mathrm{n}, \mathrm{X} \backslash \mathrm{P})(\mathrm{n}, \mathrm{X} \backslash \mathrm{A})(\mathrm{n}, 2 \mathrm{~A})(\mathrm{n}, \mathrm{PA})(\mathrm{n}, \mathrm{NA})(\mathrm{n}, \mathrm{NA})(\mathrm{n}, \mathrm{N} 3 \mathrm{HE} \mathrm{A} \text { PT NPD) }(\mathrm{n}, \mathrm{P})(\mathrm{n}, \mathrm{N})(\mathrm{n}, \mathrm{N}) \\
(\mathrm{n}, \mathrm{G})\end{array}$ \\
\hline $65 \mathrm{~Tb} 155$ & $\begin{array}{l}(\mathrm{n}, \mathrm{X} \backslash \mathrm{P})(\mathrm{n}, \mathrm{X} \backslash \mathrm{A})(\mathrm{n}, \mathrm{NA})(\mathrm{n}, \mathrm{N} 3 \mathrm{HE} \text { A PT) }(\mathrm{n}, \mathrm{N} 3 \mathrm{HE} \text { A PT) }(\mathrm{n}, \mathrm{N} 3 \mathrm{HE} \text { A PT) }(\mathrm{n}, \mathrm{P})(\mathrm{n}, \mathrm{G}) \\
(\mathrm{n}, \mathrm{G})(\mathrm{n}, \mathrm{G})\end{array}$ \\
\hline
\end{tabular}




\begin{tabular}{|c|c|}
\hline Target Nucl. & Reactions \\
\hline $65 \mathrm{~Tb} 156$ & $(\mathrm{n}, \mathrm{X} \backslash \mathrm{P})(\mathrm{n}, \mathrm{X} \backslash \mathrm{A})(\mathrm{n}, \mathrm{PA})(\mathrm{n}, \mathrm{NA})(\mathrm{n}, \mathrm{NA})(\mathrm{n}, \mathrm{NA})(\mathrm{n}, \mathrm{N} 3 \mathrm{HE} A \mathrm{PT})(\mathrm{n}, \mathrm{P})(\mathrm{n}, \mathrm{N})(\mathrm{n}, \mathrm{N})(\mathrm{n}, \mathrm{G})$ \\
\hline $65 \mathrm{~Tb} 156 \mathrm{~m} 1$ & $(\mathrm{n}, \mathrm{X} \backslash \mathrm{P})(\mathrm{n}, \mathrm{X} \backslash \mathrm{A})(\mathrm{n}, \mathrm{PA})(\mathrm{n}, \mathrm{NA})(\mathrm{n}, \mathrm{NA})(\mathrm{n}, \mathrm{NA})(\mathrm{n}, \mathrm{N} 3 \mathrm{HE} \mathrm{A} P \mathrm{PT})(\mathrm{n}, \mathrm{P})(\mathrm{n}, \mathrm{N})(\mathrm{n}, \mathrm{N})(\mathrm{n}, \mathrm{G})$ \\
\hline $65 \mathrm{~Tb} 156 \mathrm{~m} 2$ & $(\mathrm{n}, \mathrm{X} \backslash \mathrm{P})(\mathrm{n}, \mathrm{X} \backslash \mathrm{A})(\mathrm{n}, \mathrm{NA})(\mathrm{n}, \mathrm{NA})(\mathrm{n}, \mathrm{NA})(\mathrm{n}, \mathrm{N} 3 \mathrm{HE} \mathrm{A} P \mathrm{PT})(\mathrm{n}, \mathrm{P})(\mathrm{n}, \mathrm{N})(\mathrm{n}, \mathrm{N})(\mathrm{n}, \mathrm{G})$ \\
\hline $65 \mathrm{~Tb} 157$ & $(n, X \backslash P)(n, X \backslash A)(n, N A)(n, N 3 H E A)(n, N 3 H E A)(n, P)(n, G)$ \\
\hline $65 \mathrm{~Tb} 158$ & $(\mathrm{n}, \mathrm{X} \backslash \mathrm{P})(\mathrm{n}, \mathrm{X} \backslash \mathrm{A})(\mathrm{n}, \mathrm{NA})(\mathrm{n}, \mathrm{NA})(\mathrm{n}, \mathrm{N} 3 \mathrm{HE} \mathrm{A})(\mathrm{n}, \mathrm{P})(\mathrm{n}, \mathrm{N})(\mathrm{n}, \mathrm{G})$ \\
\hline $65 \mathrm{~Tb} 161$ & $(\mathrm{n}, \mathrm{X} \backslash \mathrm{A})(\mathrm{n}, \mathrm{N} 3 \mathrm{HE} \mathrm{A})(\mathrm{n}, \mathrm{G})$ \\
\hline 66 Dy 153 & $\begin{array}{l}(\mathrm{n}, \mathrm{X} \backslash \mathrm{P})(\mathrm{n}, \mathrm{X} \backslash \mathrm{A})(\mathrm{n}, 2 \mathrm{~N} 2 \mathrm{~A})(\mathrm{n}, \mathrm{N} 2 \mathrm{~A})(\mathrm{n}, 2 \mathrm{~A})(\mathrm{n}, \mathrm{NDA} 2 \mathrm{NPA})(\mathrm{n}, \mathrm{PA})(\mathrm{n}, \mathrm{NA} N \mathrm{NPT})(\mathrm{n}, \mathrm{N} 3 \mathrm{HE} \\
\text { A PT NPD } 2 \mathrm{~N} 2 \mathrm{P})(\mathrm{n}, \mathrm{P})(\mathrm{n}, \mathrm{G})\end{array}$ \\
\hline $66 \mathrm{Dy} 155$ & $(\mathrm{n}, \mathrm{X} \backslash \mathrm{P})(\mathrm{n}, \mathrm{X} \backslash \mathrm{A})(\mathrm{n}, 2 \mathrm{~A})(\mathrm{n}, \mathrm{PA})(\mathrm{n}, \mathrm{NA})(\mathrm{n}, \mathrm{N} 3 \mathrm{HE}$ A PT NPD 2N2P) $(\mathrm{n}, \mathrm{P})(\mathrm{n}, \mathrm{G})$ \\
\hline $66 \mathrm{Dy} 157$ & $(\mathrm{n}, \mathrm{X} \backslash \mathrm{P})(\mathrm{n}, \mathrm{X} \backslash \mathrm{A})(\mathrm{n}, 2 \mathrm{~A})(\mathrm{n}, \mathrm{PA})(\mathrm{n}, \mathrm{NA})(\mathrm{n}, \mathrm{N} 3 \mathrm{HE} \mathrm{A} P \mathrm{PT})(\mathrm{n}, \mathrm{P})(\mathrm{n}, \mathrm{G})$ \\
\hline 66 Dy 165 & $(\mathrm{n}, \mathrm{X} \backslash \mathrm{A})(\mathrm{n}, \mathrm{N} 3 \mathrm{HE} \mathrm{A})(\mathrm{n}, \mathrm{N})(\mathrm{n}, \mathrm{G})$ \\
\hline $66 \mathrm{Dy} 166$ & $(\mathrm{n}, \mathrm{X} \backslash \mathrm{A})(\mathrm{n}, \mathrm{N} 3 \mathrm{HE} \mathrm{A})(\mathrm{n}, \mathrm{G})$ \\
\hline 67 Ho163 & $(n, X \backslash P)(n, X \backslash A)(n, N A)(n, N 3 H E A)(n, P)(n, G)(n, G)$ \\
\hline 67 Ho164 & $(n, X \backslash P)(n, X \backslash A)(n, N A)(n, N 3 H E A)(n, P)(n, N)(n, G)$ \\
\hline 67Ho164m1 & $(n, X \backslash P)(n, X \backslash A)(n, N A)(n, N 3 H E A)(n, P)(n, N)(n, G)$ \\
\hline 67 Ho166 & $(n, X \backslash P)(n, X \backslash A)(n, N A)(n, N 3 H E A)(n, P)(n, N)(n, G)$ \\
\hline $67 \mathrm{Ho} 166 \mathrm{~m} 1$ & $(n, X \backslash P)(n, X \backslash A)(n, N A)(n, N 3 H E A)(n, P)(n, N)(n, G)$ \\
\hline $68 \operatorname{Er} 160$ & $(\mathrm{n}, \mathrm{X} \backslash \mathrm{P})(\mathrm{n}, \mathrm{X} \backslash \mathrm{A})(\mathrm{n}, 2 \mathrm{~A})(\mathrm{n}, \mathrm{PA})(\mathrm{n}, \mathrm{NA})(\mathrm{n}, \mathrm{N} 3 \mathrm{HE} \mathrm{A} P \mathrm{PT})(\mathrm{n}, \mathrm{P})(\mathrm{n}, \mathrm{P})(\mathrm{n}, \mathrm{P})(\mathrm{n}, \mathrm{G})$ \\
\hline $68 \operatorname{Er} 161$ & $(\mathrm{n}, \mathrm{X} \backslash \mathrm{P})(\mathrm{n}, \mathrm{X} \backslash \mathrm{A})(\mathrm{n}, 2 \mathrm{~A})(\mathrm{n}, \mathrm{PA})(\mathrm{n}, \mathrm{NA})(\mathrm{n}, \mathrm{N} 3 \mathrm{HE}$ A PT NPD 2N2P) $(\mathrm{n}, \mathrm{P})(\mathrm{n}, \mathrm{P})(\mathrm{n}, \mathrm{G})$ \\
\hline $68 \operatorname{Er} 165$ & $(n, X \backslash P)(n, X \backslash A)(n, N A)(n, N 3 H E A)(n, P)(n, G)$ \\
\hline $68 \operatorname{Er} 169$ & $(\mathrm{n}, \mathrm{X} \backslash \mathrm{A})(\mathrm{n}, \mathrm{NA})(\mathrm{n}, \mathrm{NA})(\mathrm{n}, \mathrm{N} 3 \mathrm{HE} \mathrm{A})(\mathrm{n}, \mathrm{G})$ \\
\hline $68 \operatorname{Er} 171$ & $(\mathrm{n}, \mathrm{X} \backslash \mathrm{A})(\mathrm{n}, \mathrm{N} 3 \mathrm{HE} \mathrm{A})(\mathrm{n}, \mathrm{G})$ \\
\hline $68 \operatorname{Er} 172$ & $(\mathrm{n}, \mathrm{X} \backslash \mathrm{A})(\mathrm{n}, \mathrm{N} 3 \mathrm{HE} \mathrm{A})(\mathrm{n}, \mathrm{G})$ \\
\hline $69 \operatorname{Tm} 165$ & $\begin{array}{l}(\mathrm{n}, \mathrm{X} \backslash \mathrm{P})(\mathrm{n}, \mathrm{X} \backslash \mathrm{A})(\mathrm{n}, 2 \mathrm{~A})(\mathrm{n}, \mathrm{PA})(\mathrm{n}, \mathrm{NA})(\mathrm{n}, \mathrm{NA})(\mathrm{n}, \mathrm{N} 3 \mathrm{HE} \text { A PT) (n,N3HE A PT) (n,P) } \\
(\mathrm{n}, \mathrm{G})\end{array}$ \\
\hline $69 \mathrm{Tm} 166$ & $\begin{array}{l}(\mathrm{n}, \mathrm{X} \backslash \mathrm{P})(\mathrm{n}, \mathrm{X} \backslash \mathrm{A})(\mathrm{n}, 2 \mathrm{~A})(\mathrm{n}, \mathrm{PA})(\mathrm{n}, \mathrm{NA})(\mathrm{n}, \mathrm{NA})(\mathrm{n}, \mathrm{N} 3 \mathrm{HE} \mathrm{A} \mathrm{PT})(\mathrm{n}, \mathrm{N} 3 \mathrm{HE} \mathrm{A} \text { PT) }(\mathrm{n}, \mathrm{P}) \\
(\mathrm{n}, \mathrm{G})\end{array}$ \\
\hline $69 \mathrm{Tm} 167$ & $(\mathrm{n}, \mathrm{X} \backslash \mathrm{P})(\mathrm{n}, \mathrm{X} \backslash \mathrm{A})(\mathrm{n}, \mathrm{NA})(\mathrm{n}, \mathrm{NA})(\mathrm{n}, \mathrm{N} 3 \mathrm{HE} \mathrm{A})(\mathrm{n}, \mathrm{N} 3 \mathrm{HE} \mathrm{A})(\mathrm{n}, \mathrm{P})(\mathrm{n}, \mathrm{P})(\mathrm{n}, \mathrm{G})$ \\
\hline $69 \mathrm{Tm} 168$ & $(n, X \backslash P)(n, X \backslash A)(n, N A)(n, N A)(n, N 3 H E A)(n, P)(n, G)$ \\
\hline $69 \mathrm{Tm} 170$ & $(n, X \backslash P)(n, X \backslash A)(n, N A)(n, N A)(n, N 3 H E A)(n, P)(n, G)$ \\
\hline $69 \mathrm{Tm} 171$ & $(\mathrm{n}, \mathrm{X} \backslash \mathrm{P})(\mathrm{n}, \mathrm{X} \backslash \mathrm{A})(\mathrm{n}, \mathrm{NA})(\mathrm{n}, \mathrm{N} 3 \mathrm{HE} \mathrm{A})(\mathrm{n}, \mathrm{N} 3 \mathrm{HE} \mathrm{A})(\mathrm{n}, \mathrm{G})$ \\
\hline $69 \mathrm{Tm} 172$ & $(\mathrm{n}, \mathrm{X} \backslash \mathrm{P})(\mathrm{n}, \mathrm{X} \backslash \mathrm{A})(\mathrm{n}, \mathrm{NA})(\mathrm{n}, \mathrm{NA})(\mathrm{n}, \mathrm{N} 3 \mathrm{HE} \mathrm{A})(\mathrm{n}, \mathrm{P})(\mathrm{n}, \mathrm{G})$ \\
\hline $69 \mathrm{Tm} 173$ & $(\mathrm{n}, \mathrm{X} \backslash \mathrm{A})(\mathrm{n}, \mathrm{NA})(\mathrm{n}, \mathrm{N} 3 \mathrm{HE} \mathrm{A})(\mathrm{n}, \mathrm{N} 3 \mathrm{HE} \mathrm{A})(\mathrm{n}, \mathrm{G})$ \\
\hline $70 \mathrm{Yb} 166$ & $(\mathrm{n}, \mathrm{X} \backslash \mathrm{P})(\mathrm{n}, \mathrm{X} \backslash \mathrm{A})(\mathrm{n}, 2 \mathrm{~A})(\mathrm{n}, \mathrm{PA})(\mathrm{n}, \mathrm{PA})(\mathrm{n}, \mathrm{NA})(\mathrm{n}, \mathrm{N} 3 \mathrm{HE} \mathrm{A} \mathrm{PT})(\mathrm{n}, \mathrm{P})(\mathrm{n}, \mathrm{G})$ \\
\hline $70 \mathrm{Yb} 169$ & $(n, X \backslash P)(n, X \backslash A)(n, P A)(n, N A)(n, N 3 H E A P T)(n, P)(n, N)(n, G)$ \\
\hline $70 \mathrm{Yb} 175$ & $(\mathrm{n}, \mathrm{X} \backslash \mathrm{A})(\mathrm{n}, \mathrm{NA})(\mathrm{n}, \mathrm{N} 3 \mathrm{HE} \mathrm{A})(\mathrm{n}, \mathrm{G})(\mathrm{n}, \mathrm{G})$ \\
\hline $71 \mathrm{Lu} 169$ & $\begin{array}{l}(\mathrm{n}, \mathrm{X} \backslash \mathrm{P})(\mathrm{n}, \mathrm{X} \backslash \mathrm{A})(\mathrm{n}, 2 \mathrm{~A})(\mathrm{n}, 2 \mathrm{~A})(\mathrm{n}, \mathrm{PA})(\mathrm{n}, \mathrm{NA})(\mathrm{n}, \mathrm{N} 3 \mathrm{HE} \mathrm{A} P \mathrm{PT})(\mathrm{n}, \mathrm{P})(\mathrm{n}, \mathrm{P})(\mathrm{n}, \mathrm{N})(\mathrm{n}, \mathrm{G}) \\
(\mathrm{n}, \mathrm{G})\end{array}$ \\
\hline $71 \mathrm{Lu} 170$ & $\begin{array}{l}(\mathrm{n}, \mathrm{X} \backslash \mathrm{P})(\mathrm{n}, \mathrm{X} \backslash \mathrm{A})(\mathrm{n}, 2 \mathrm{~A})(\mathrm{n}, 2 \mathrm{~A})(\mathrm{n}, \mathrm{NDA} 2 \mathrm{NPA})(\mathrm{n}, \mathrm{PA})(\mathrm{n}, \mathrm{NA})(\mathrm{n}, \mathrm{N} 3 \mathrm{HE} \text { A PT NPD) } \\
(\mathrm{n}, \mathrm{P})(\mathrm{n}, \mathrm{N})(\mathrm{n}, \mathrm{G})(\mathrm{n}, \mathrm{G})\end{array}$ \\
\hline $71 \mathrm{Lu} 171$ & $(\mathrm{n}, \mathrm{X} \backslash \mathrm{P})(\mathrm{n}, \mathrm{X} \backslash \mathrm{A})(\mathrm{n}, \mathrm{NPA})(\mathrm{n}, \mathrm{PA})(\mathrm{n}, \mathrm{PA})(\mathrm{n}, \mathrm{NA})(\mathrm{n}, \mathrm{N} 3 \mathrm{HE} \mathrm{A} \mathrm{PT})(\mathrm{n}, \mathrm{P})(\mathrm{n}, \mathrm{N})(\mathrm{n}, \mathrm{G})$ \\
\hline
\end{tabular}




\begin{tabular}{|c|c|}
\hline Target Nucl. & Reactions \\
\hline $71 \mathrm{Lu} 172$ & $(n, X \backslash P)(n, X \backslash A)(n, 2 A)(n, N P A D A)(n, P A)(n, N A)(n, N 3 H E A P T)(n, P)(n, N)(n, G)$ \\
\hline $71 \mathrm{Lu} 173$ & $(n, X \backslash P)(n, X \backslash A)(n, N A)(n, N 3 H E A)(n, P)(n, G)(n, G)$ \\
\hline $71 \mathrm{Lu} 174$ & $(n, X \backslash P)(n, X \backslash A)(n, N A)(n, N 3 H E A)(n, P)(n, N)(n, G)$ \\
\hline $71 \mathrm{Lu} 174 \mathrm{~m} 1$ & $(n, X \backslash P)(n, X \backslash A)(n, N A)(n, N 3 H E A)(n, P)(n, N)(n, G)$ \\
\hline $71 \mathrm{Lu} 177$ & $(n, X \backslash P)(n, X \backslash A)(n, N A)(n, N 3 H E A)(n, G)(n, G)$ \\
\hline $71 \mathrm{Lu} 177 \mathrm{~m} 1$ & $(n, X \backslash P)(n, X \backslash A)(n, N A)(n, A)(n, P)(n, P)(n, N)(n, G)(n, G)$ \\
\hline $72 \mathrm{Hf} 170$ & $(n, X \backslash P)(n, X \backslash A)(n, 2 A)(n, P A)(n, N A)(n, N 3 H E$ A PT NPD) $(n, P)(n, P)(n, G)(n, G)$ \\
\hline $72 \mathrm{Hf} 171$ & $(\mathrm{n}, \mathrm{X} \backslash \mathrm{P})(\mathrm{n}, \mathrm{X} \backslash \mathrm{A})(\mathrm{n}, 2 \mathrm{~A})(\mathrm{n}, \mathrm{PA})(\mathrm{n}, \mathrm{NA})(\mathrm{n}, \mathrm{N} 3 \mathrm{HE}$ A PT NPD 2N2P) $(\mathrm{n}, \mathrm{P})(\mathrm{n}, \mathrm{P})(\mathrm{n}, \mathrm{G})$ \\
\hline $72 \mathrm{Hf} 172$ & $(\mathrm{n}, \mathrm{X} \backslash \mathrm{P})(\mathrm{n}, \mathrm{X} \backslash \mathrm{A})(\mathrm{n}, 2 \mathrm{~A})(\mathrm{n}, \mathrm{PA})(\mathrm{n}, \mathrm{NA})(\mathrm{n}, \mathrm{N} 3 \mathrm{HE}$ A PT) $(\mathrm{n}, \mathrm{N} 3 \mathrm{HE}$ A PT) $(\mathrm{n}, \mathrm{P})(\mathrm{n}, \mathrm{G})$ \\
\hline $72 \mathrm{Hf} 173$ & $(n, X \backslash P)(n, X \backslash A)(n, 2 A)(n, P A)(n, N A)(n, N A)(n, N 3 H E$ A PT NPD) $(n, P)(n, G)$ \\
\hline $72 \mathrm{Hf} 175$ & $(n, X \backslash P)(n, X \backslash A)(n, P A)(n, N A)(n, N 3 H E A)(n, P)(n, G)$ \\
\hline $72 \mathrm{Hf} 178 \mathrm{~m} 2$ & $(n, X \backslash P)(n, X \backslash A)(n, N A)(n, A)(n, P)(n, P)(n, N)(n, N)(n, G)(n, G)(n, G)$ \\
\hline $72 \mathrm{Hf} 179 \mathrm{~m} 2$ & $(n, X \backslash P)(n, X \backslash A)(n, N A)(n, A)(n, A)(n, P)(n, N)(n, N)(n, G)(n, G)$ \\
\hline $72 \mathrm{Hf} 180 \mathrm{~m} 1$ & $(n, X \backslash A)(n, N A)(n, N A)(n, N 3 H E A)(n, N 3 H E A)(n, N)(n, G)$ \\
\hline $73 \mathrm{Ta} 175$ & $(n, X \backslash P)(n, X \backslash A)(n, 2 A)(n, P A)(n, N A)(n, N A)(n, N 3 H E A$ PT) $(n, P)(n, G)$ \\
\hline $73 \mathrm{Ta} 176$ & $(n, X \backslash P)(n, X \backslash A)(n, 2 A)(n, P A)(n, N A)(n, N 3 H E A P T)(n, P)(n, G)$ \\
\hline $73 \mathrm{Ta} 177$ & $(n, X \backslash P)(n, X \backslash A)(n, 2 A)(n, P A)(n, N A)(n, N 3 H E$ A PT) $(n, N 3 H E$ A PT) $(n, P)(n, G)$ \\
\hline 73 Ta179 & $(n, X \backslash P)(n, X \backslash A)(n, N A)(n, N 3 H E A)(n, N 3 H E A)(n, P)(n, G)(n, G)$ \\
\hline $73 \mathrm{Ta} 180$ & $\begin{array}{l}(\mathrm{n}, \mathrm{X} \backslash \mathrm{P})(\mathrm{n}, \mathrm{X} \backslash \mathrm{A})(\mathrm{n}, \mathrm{NA})(\mathrm{n}, \mathrm{NA})(\mathrm{n}, \mathrm{N} 3 \mathrm{HE} \mathrm{A})(\mathrm{n}, \mathrm{N} 3 \mathrm{HE} \mathrm{A})(\mathrm{n}, \mathrm{N} 3 \mathrm{HE} \mathrm{A})(\mathrm{n}, \mathrm{P})(\mathrm{n}, \mathrm{P})(\mathrm{n}, \mathrm{N}) \\
(\mathrm{n}, \mathrm{G})\end{array}$ \\
\hline $73 \mathrm{Ta} 180 \mathrm{~m} 1$ & $\begin{array}{l}(\mathrm{n}, \mathrm{X} \backslash \mathrm{P})(\mathrm{n}, \mathrm{X} \backslash \mathrm{A})(\mathrm{n}, \mathrm{NA})(\mathrm{n}, \mathrm{NA})(\mathrm{n}, \mathrm{N} 3 \mathrm{HE} \mathrm{A})(\mathrm{n}, \mathrm{N} 3 \mathrm{HE} \mathrm{A})(\mathrm{n}, \mathrm{N} 3 \mathrm{HE} \mathrm{A})(\mathrm{n}, \mathrm{P})(\mathrm{n}, \mathrm{P})(\mathrm{n}, \mathrm{N}) \\
(\mathrm{n}, \mathrm{G})\end{array}$ \\
\hline $73 \mathrm{Ta} 183$ & $(n, X \backslash A)(n, N A)(n, N 3 H E A)(n, N 3 H E A)(n, G)$ \\
\hline $73 \mathrm{Ta} 184$ & $(n, X \backslash P)(n, X \backslash A)(n, N A)(n, N A)(n, N 3 H E A)(n, G)$ \\
\hline 74W 178 & $(n, X \backslash P)(n, X \backslash A)(n, 2 A)(n, P A)(n, P A)(n, N A)(n, N 3 H E A P T)(n, P)(n, G)(n, G)$ \\
\hline 74W181 & $(n, X \backslash P)(n, X \backslash A)(n, N A)(n, N A)(n, N 3 H E A)(n, N 3 H E A)(n, N 3 H E A)(n, P)(n, G)$ \\
\hline 74W 185 & $(n, X \backslash A)(n, N A)(n, N 3 H E A)(n, N 3 H E A)(n, G)$ \\
\hline $74 \mathrm{~W} 187$ & $(n, X \backslash A)(n, N A)(n, N 3 H E A)(n, N 3 H E A)(n, G)$ \\
\hline $74 \mathrm{~W} 188$ & $(\mathrm{n}, \mathrm{X} \backslash \mathrm{A})(\mathrm{n}, \mathrm{NA})(\mathrm{n}, \mathrm{N} 3 \mathrm{HE} \mathrm{A})(\mathrm{n}, \mathrm{G})$ \\
\hline $75 \operatorname{Re} 181$ & $(n, X \backslash P)(n, X \backslash A)(n, 2 A)(n, 2 A)(n, P A)(n, P A)(n, N A)(n, N 3 H E A$ PT) $(n, P)(n, G)(n, G)$ \\
\hline $75 \operatorname{Re} 182$ & $(n, X \backslash P)(n, X \backslash A)(n, T A$ NDA 2NPA) (n,PA) (n,NA) (n,N3HE A PT) $(n, P)(n, N)(n, G)$ \\
\hline $75 \operatorname{Re} 182 \mathrm{~m} 1$ & $\begin{array}{l}(n, X \backslash P)(n, X \backslash A)(n, N 2 A)(n, N 2 A)(n, P A)(n, P A)(n, P A)(n, N A ~ N P T)(n, N 3 H E A \text { PT } \\
N P D 2 N 2 P)(n, P)(n, N)(n, G)\end{array}$ \\
\hline $75 \operatorname{Re} 183$ & $(n, X \backslash P)(n, X \backslash A)(n, N A)(n, N 3 H E A)(n, N 3 H E A)(n, P)(n, P)(n, G)(n, G)$ \\
\hline $75 \operatorname{Re} 184$ & $(n, X \backslash P)(n, X \backslash A)(n, N A)(n, N A)(n, N 3 H E A)(n, P)(n, G)$ \\
\hline $75 \operatorname{Re} 184 \mathrm{~m} 1$ & $(n, X \backslash P)(n, X \backslash A)(n, N A)(n, N A)(n, N 3 H E A)(n, P)(n, N)(n, G)$ \\
\hline $75 \operatorname{Re} 186$ & $(n, X \backslash P)(n, X \backslash A)(n, N A)(n, N A)(n, N A)(n, N 3 H E A)(n, P)(n, N)(n, G)$ \\
\hline $75 \operatorname{Re} 186 \mathrm{~m} 1$ & $(n, X \backslash P)(n, X \backslash A)(n, N A)(n, N A)(n, N A)(n, N 3 H E A)(n, P)(n, N)(n, G)$ \\
\hline $75 \operatorname{Re} 188$ & $(n, X \backslash P)(n, X \backslash A)(n, N A)(n, N 3 H E A)(n, P)(n, N)(n, G)$ \\
\hline $75 \operatorname{Re} 189$ & $(n, X \backslash A)(n, N A)(n, N 3 H E A)(n, G)(n, G)$ \\
\hline
\end{tabular}




\begin{tabular}{|c|c|}
\hline Target Nucl. & Reactions \\
\hline $76 \mathrm{Os} 182$ & $\begin{array}{l}(\mathrm{n}, \mathrm{X} \backslash \mathrm{P})(\mathrm{n}, \mathrm{X} \backslash \mathrm{A})(\mathrm{n}, 2 \mathrm{~A})(\mathrm{n}, \mathrm{PA})(\mathrm{n}, \mathrm{NA})(\mathrm{n}, \mathrm{N} 3 \mathrm{HE} \text { A PT) }(\mathrm{n}, \mathrm{N} 3 \mathrm{HE} \text { A PT) }(\mathrm{n}, \mathrm{P})(\mathrm{n}, \mathrm{P})(\mathrm{n}, \mathrm{G}) \\
(\mathrm{n}, \mathrm{G})\end{array}$ \\
\hline $76 \mathrm{Os} 183$ & $(\mathrm{n}, \mathrm{X} \backslash \mathrm{P})(\mathrm{n}, \mathrm{X} \backslash \mathrm{A})(\mathrm{n}, 2 \mathrm{~A})(\mathrm{n}, \mathrm{PA})(\mathrm{n}, \mathrm{NA})(\mathrm{n}, \mathrm{NA})(\mathrm{n}, \mathrm{N} 3 \mathrm{HE}$ A PT NPD) $(\mathrm{n}, \mathrm{P})(\mathrm{n}, \mathrm{N})(\mathrm{n}, \mathrm{G})$ \\
\hline $760 \mathrm{Os} 183 \mathrm{~m} 1$ & $(\mathrm{n}, \mathrm{X} \backslash \mathrm{P})(\mathrm{n}, \mathrm{X} \backslash \mathrm{A})(\mathrm{n}, 2 \mathrm{~A})(\mathrm{n}, \mathrm{PA})(\mathrm{n}, \mathrm{NA})(\mathrm{n}, \mathrm{NA})(\mathrm{n}, \mathrm{N} 3 \mathrm{HE}$ A PT NPD) $(\mathrm{n}, \mathrm{P})(\mathrm{n}, \mathrm{G})$ \\
\hline $76 \mathrm{Os} 185$ & $(n, X \backslash P)(n, X \backslash A)(n, P A)(n, N A)(n, N 3 H E A)(n, P)(n, G)$ \\
\hline $760 s 191$ & $(n, X \backslash A)(n, N A)(n, N 3 H E A)(n, N)(n, G)(n, G)$ \\
\hline $760 \mathrm{~s} 191 \mathrm{~m} 1$ & $(n, X \backslash A)(n, N A)(n, N 3 H E A)(n, N)(n, G)(n, G)$ \\
\hline $760 s 193$ & $(\mathrm{n}, \mathrm{X} \backslash \mathrm{A})(\mathrm{n}, \mathrm{N} 3 \mathrm{HE} \mathrm{A})(\mathrm{n}, \mathrm{G})$ \\
\hline $76 \mathrm{Os} 194$ & $(n, X \backslash A)(n, N A)(n, N 3 H E A)(n, G)$ \\
\hline 77Ir185 & $\begin{array}{l}(\mathrm{n}, \mathrm{X} \backslash \mathrm{P})(\mathrm{n}, \mathrm{X} \backslash \mathrm{A})(\mathrm{n}, 2 \mathrm{~A})(\mathrm{n}, \mathrm{NDA} 2 \mathrm{NPA})(\mathrm{n}, \mathrm{NDA} 2 \mathrm{NPA})(\mathrm{n}, \mathrm{DA})(\mathrm{n}, \mathrm{PA})(\mathrm{n}, \mathrm{NA})(\mathrm{n}, \mathrm{N} 3 \mathrm{HE} \\
\text { A PT) (n,N3HE A PT) (n,P) }(\mathrm{n}, \mathrm{G})(\mathrm{n}, \mathrm{G})\end{array}$ \\
\hline 77Ir186 & $\begin{array}{l}(\mathrm{n}, \mathrm{X} \backslash \mathrm{P})(\mathrm{n}, \mathrm{X} \backslash \mathrm{A})(\mathrm{n}, 2 \mathrm{~A})(\mathrm{n}, \mathrm{DA})(\mathrm{n}, \mathrm{PA})(\mathrm{n}, \mathrm{NA})(\mathrm{n}, \mathrm{NA})(\mathrm{n}, \mathrm{N} 3 \mathrm{HE} \text { A PT NPD } 2 \mathrm{~N} 2 \mathrm{P})(\mathrm{n}, \mathrm{P}) \\
(\mathrm{n}, \mathrm{N})(\mathrm{n}, \mathrm{G})\end{array}$ \\
\hline 77Ir187 & $\begin{array}{l}(\mathrm{n}, \mathrm{X} \backslash \mathrm{P})(\mathrm{n}, \mathrm{X} \backslash \mathrm{A})(\mathrm{n}, \mathrm{NDA} 2 \mathrm{NPA})(\mathrm{n}, \mathrm{PA})(\mathrm{n}, \mathrm{PA})(\mathrm{n}, \mathrm{NA})(\mathrm{n}, \mathrm{N} 3 \mathrm{HE} \text { A PT) (n,N3HE A PT) } \\
(\mathrm{n}, \mathrm{P})(\mathrm{n}, \mathrm{G})\end{array}$ \\
\hline 77Ir188 & $(\mathrm{n}, \mathrm{X} \backslash \mathrm{P})(\mathrm{n}, \mathrm{X} \backslash \mathrm{A})(\mathrm{n}, \mathrm{PA})(\mathrm{n}, \mathrm{NA})(\mathrm{n}, \mathrm{NA})(\mathrm{n}, \mathrm{N} 3 \mathrm{HE} \mathrm{A})(\mathrm{n}, \mathrm{P})(\mathrm{n}, \mathrm{G})$ \\
\hline 77Ir189 & $(n, X \backslash P)(n, X \backslash A)(n, N A)(n, N 3 H E A)(n, N 3 H E A)(n, P)(n, P)(n, G)$ \\
\hline $77 \operatorname{Ir} 190$ & $(n, X \backslash P)(n, X \backslash A)(n, N A)(n, N A)(n, N 3 H E A)(n, P)(n, P)(n, N)(n, N)(n, G)(n, G)$ \\
\hline 77Ir192 & $(\mathrm{n}, \mathrm{X} \backslash \mathrm{P})(\mathrm{n}, \mathrm{X} \backslash \mathrm{A})(\mathrm{n}, \mathrm{NA})(\mathrm{n}, \mathrm{NA})(\mathrm{n}, \mathrm{N} 3 \mathrm{HE} \mathrm{A})(\mathrm{n}, \mathrm{P})(\mathrm{n}, \mathrm{N})(\mathrm{n}, \mathrm{N})(\mathrm{n}, \mathrm{G})(\mathrm{n}, \mathrm{G})$ \\
\hline 77) $\operatorname{Ir} 192 \mathrm{~m} 2$ & $(n, X \backslash P)(n, X \backslash A)(n, N A)(n, N A)(n, N 3 H E A)(n, P)(n, P)(n, N)(n, N)(n, G)(n, G)$ \\
\hline 77Ir193m1 & $(n, X \backslash P)(n, X \backslash A)(n, N A)(n, N 3 H E A)(n, N 3 H E A)(n, N)(n, G)(n, G)(n, G)$ \\
\hline $77 \operatorname{Ir} 194$ & $(\mathrm{n}, \mathrm{X} \backslash \mathrm{P})(\mathrm{n}, \mathrm{X} \backslash \mathrm{A})(\mathrm{n}, \mathrm{NA})(\mathrm{n}, \mathrm{NA})(\mathrm{n}, \mathrm{N} 3 \mathrm{HE} \mathrm{A})(\mathrm{n}, \mathrm{P})(\mathrm{n}, \mathrm{N})(\mathrm{n}, \mathrm{G})(\mathrm{n}, \mathrm{G})$ \\
\hline $77 \operatorname{Ir} 194 \mathrm{~m} 2$ & $(n, X \backslash P)(n, X \backslash A)(n, N A)(n, N A)(n, A)(n, P)(n, N)(n, N)(n, G)(n, G)$ \\
\hline $77 \operatorname{Ir} 196 \mathrm{~m} 1$ & $(n, X \backslash P)(n, X \backslash A)(n, N A)(n, N 3 H E A)(n, P)(n, N)(n, G)(n, G)$ \\
\hline $78 \mathrm{Pt} 188$ & $(\mathrm{n}, \mathrm{X} \backslash \mathrm{P})(\mathrm{n}, \mathrm{X} \backslash \mathrm{A})(\mathrm{n}, 2 \mathrm{~A})(\mathrm{n}, \mathrm{PA})(\mathrm{n}, \mathrm{PA})(\mathrm{n}, \mathrm{NA})(\mathrm{n}, \mathrm{N} 3 \mathrm{HE}$ A PT) $(\mathrm{n}, \mathrm{P})(\mathrm{n}, \mathrm{G})$ \\
\hline $78 \mathrm{Pt} 189$ & $(\mathrm{n}, \mathrm{X} \backslash \mathrm{P})(\mathrm{n}, \mathrm{X} \backslash \mathrm{A})(\mathrm{n}, 2 \mathrm{~A})(\mathrm{n}, \mathrm{PA})(\mathrm{n}, \mathrm{NA})(\mathrm{n}, \mathrm{N} 3 \mathrm{HE}$ A PT NPD 2N2P) $(\mathrm{n}, \mathrm{P})(\mathrm{n}, \mathrm{G})$ \\
\hline $78 \mathrm{Pt} 190$ & $(\mathrm{n}, \mathrm{X} \backslash \mathrm{P})(\mathrm{n}, \mathrm{X} \backslash \mathrm{A})(\mathrm{n}, \mathrm{NA})(\mathrm{n}, \mathrm{N} 3 \mathrm{HE} \mathrm{A} \mathrm{PT})(\mathrm{n}, \mathrm{P})(\mathrm{n}, \mathrm{G})$ \\
\hline $78 \mathrm{Pt} 191$ & $(\mathrm{n}, \mathrm{X} \backslash \mathrm{P})(\mathrm{n}, \mathrm{X} \backslash \mathrm{A})(\mathrm{n}, 2 \mathrm{~A})(\mathrm{n}, \mathrm{NA})(\mathrm{n}, \mathrm{N} 3 \mathrm{HE} \mathrm{A})(\mathrm{n}, \mathrm{P})(\mathrm{n}, \mathrm{G})$ \\
\hline $78 \mathrm{Pt} 192$ & $(n, X \backslash P)(n, X \backslash A)(n, N A)(n, N 3 H E A)(n, N 3 H E A)(n, G)(n, G)$ \\
\hline $78 P t 193$ & $(n, X \backslash P)(n, X \backslash A)(n, N A)(n, N A)(n, N 3 H E A)(n, N 3 H E A)(n, P)(n, P)(n, N)(n, G)$ \\
\hline $78 \mathrm{Pt} 193 \mathrm{~m} 1$ & $(n, X \backslash P)(n, X \backslash A)(n, N A)(n, N A)(n, N 3 H E A)(n, N 3 H E A)(n, P)(n, P)(n, N)(n, G)$ \\
\hline $78 \mathrm{Pt} 194$ & $(\mathrm{n}, \mathrm{X} \backslash \mathrm{A})(\mathrm{n}, \mathrm{NA})(\mathrm{n}, \mathrm{N} 3 \mathrm{HE} \mathrm{A})(\mathrm{n}, \mathrm{N} 3 \mathrm{HE} \mathrm{A})(\mathrm{n}, \mathrm{G})(\mathrm{n}, \mathrm{G})$ \\
\hline $78 \mathrm{Pt} 195$ & $(n, X \backslash P)(n, X \backslash A)(n, N A)(n, N A)(n, N 3 H E A)(n, N 3 H E A)(n, G)$ \\
\hline $78 \mathrm{Pt} 195 \mathrm{~m} 1$ & $(n, X \backslash P)(n, X \backslash A)(n, N A)(n, N A)(n, N 3 H E A)(n, N 3 H E A)(n, P)(n, N)(n, G)$ \\
\hline 78Pt196 & $(n, X \backslash A)(n, N A)(n, N 3 H E A)(n, G)(n, G)$ \\
\hline 78 Pt197 & $(\mathrm{n}, \mathrm{X} \backslash \mathrm{A})(\mathrm{n}, \mathrm{NA})(\mathrm{n}, \mathrm{N} 3 \mathrm{HE} \mathrm{A})(\mathrm{n}, \mathrm{G})$ \\
\hline $78 \mathrm{Pt} 198$ & $(n, X \backslash A)(n, N A)(n, N 3 H E A)(n, G)(n, G)$ \\
\hline $78 \mathrm{Pt} 200$ & $(\mathrm{n}, \mathrm{X} \backslash \mathrm{A})(\mathrm{n}, \mathrm{A})(\mathrm{n}, \mathrm{G})$ \\
\hline $78 \mathrm{Pt} 202$ & $(\mathrm{n}, \mathrm{X} \backslash \mathrm{A})(\mathrm{n}, \mathrm{A})(\mathrm{n}, \mathrm{G})$ \\
\hline 79Au193 & $(n, X \backslash P)(n, X \backslash A)(n, N A)(n, N 3 H E A)(n, P)(n, P)(n, G)(n, G)(n, G)$ \\
\hline
\end{tabular}




\begin{tabular}{|c|c|}
\hline Target Nucl. & Reactions \\
\hline 79Au194 & $(\mathrm{n}, \mathrm{X} \backslash \mathrm{P})(\mathrm{n}, \mathrm{X} \backslash \mathrm{A})(\mathrm{n}, \mathrm{NA})(\mathrm{n}, \mathrm{N} 3 \mathrm{HE} \mathrm{A})(\mathrm{n}, \mathrm{N} 3 \mathrm{HE} \mathrm{A})(\mathrm{n}, \mathrm{N} 3 \mathrm{HE} \mathrm{A})(\mathrm{n}, \mathrm{P})(\mathrm{n}, \mathrm{N})(\mathrm{n}, \mathrm{G})(\mathrm{n}, \mathrm{G})$ \\
\hline 79Au195 & $\begin{array}{l}(\mathrm{n}, \mathrm{X} \backslash \mathrm{P})(\mathrm{n}, \mathrm{X} \backslash \mathrm{A})(\mathrm{n}, \mathrm{NA})(\mathrm{n}, \mathrm{N} 3 \mathrm{HE} \mathrm{A})(\mathrm{n}, \mathrm{N} 3 \mathrm{HE} \mathrm{A})(\mathrm{n}, \mathrm{N} 3 \mathrm{HE} \mathrm{A})(\mathrm{n}, \mathrm{P})(\mathrm{n}, \mathrm{P})(\mathrm{n}, \mathrm{G})(\mathrm{n}, \mathrm{G}) \\
(\mathrm{n}, \mathrm{G})\end{array}$ \\
\hline 79Au196 & $\begin{array}{l}(\mathrm{n}, \mathrm{X} \backslash \mathrm{P})(\mathrm{n}, \mathrm{X} \backslash \mathrm{A})(\mathrm{n}, \mathrm{NA})(\mathrm{n}, \mathrm{NA})(\mathrm{n}, \mathrm{NA})(\mathrm{n}, \mathrm{N} 3 \mathrm{HE} \mathrm{A})(\mathrm{n}, \mathrm{N} 3 \mathrm{HE} \mathrm{A})(\mathrm{n}, \mathrm{P})(\mathrm{n}, \mathrm{N})(\mathrm{n}, \mathrm{N})(\mathrm{n}, \mathrm{G}) \\
(\mathrm{n}, \mathrm{G})\end{array}$ \\
\hline 79Au196m2 & $(\mathrm{n}, \mathrm{X} \backslash \mathrm{P})(\mathrm{n}, \mathrm{X} \backslash \mathrm{A})(\mathrm{n}, \mathrm{NA})(\mathrm{n}, \mathrm{NA})(\mathrm{n}, \mathrm{NA})(\mathrm{n}, \mathrm{N} 3 \mathrm{HE} \mathrm{A})(\mathrm{n}, \mathrm{N} 3 \mathrm{HE} \mathrm{A})(\mathrm{n}, \mathrm{P})(\mathrm{n}, \mathrm{G})(\mathrm{n}, \mathrm{G})$ \\
\hline 79Au198 & $(\mathrm{n}, \mathrm{X} \backslash \mathrm{P})(\mathrm{n}, \mathrm{X} \backslash \mathrm{A})(\mathrm{n}, \mathrm{NA})(\mathrm{n}, \mathrm{NA})(\mathrm{n}, \mathrm{NA})(\mathrm{n}, \mathrm{N} 3 \mathrm{HE} \mathrm{A})(\mathrm{n}, \mathrm{N} 3 \mathrm{HE} \mathrm{A})(\mathrm{n}, \mathrm{P})(\mathrm{n}, \mathrm{G})$ \\
\hline 79Au198m1 & $(\mathrm{n}, \mathrm{X} \backslash \mathrm{P})(\mathrm{n}, \mathrm{X} \backslash \mathrm{A})(\mathrm{n}, \mathrm{NA})(\mathrm{n}, \mathrm{NA})(\mathrm{n}, \mathrm{NA})(\mathrm{n}, \mathrm{A})(\mathrm{n}, \mathrm{A})(\mathrm{n}, \mathrm{P})(\mathrm{n}, \mathrm{N})(\mathrm{n}, \mathrm{G})$ \\
\hline 79Au199 & $(\mathrm{n}, \mathrm{X} \backslash \mathrm{P})(\mathrm{n}, \mathrm{X} \backslash \mathrm{A})(\mathrm{n}, \mathrm{NA})(\mathrm{n}, \mathrm{NA})(\mathrm{n}, \mathrm{N} 3 \mathrm{HE} \mathrm{A})(\mathrm{n}, \mathrm{A})(\mathrm{n}, \mathrm{P})(\mathrm{n}, \mathrm{G})(\mathrm{n}, \mathrm{G})$ \\
\hline 79Au200m1 & $(n, X \backslash P)(n, X \backslash A)(n, N A)(n, N A)(n, N 3 H E A)(n, N 3 H E A)(n, P)(n, N)(n, G)$ \\
\hline $80 \mathrm{Hg} 193$ & $\begin{array}{l}(\mathrm{n}, \mathrm{X} \backslash \mathrm{P})(\mathrm{n}, \mathrm{X} \backslash \mathrm{A})(\mathrm{n}, 2 \mathrm{~A})(\mathrm{n}, \mathrm{NDA} 2 \mathrm{NPA})(\mathrm{n}, \mathrm{PA})(\mathrm{n}, \mathrm{NA})(\mathrm{n}, \mathrm{N} 3 \mathrm{HE} \text { A PT) }(\mathrm{n}, \mathrm{P})(\mathrm{n}, \mathrm{P})(\mathrm{n}, \mathrm{N}) \\
(\mathrm{n}, \mathrm{G})\end{array}$ \\
\hline $80 \mathrm{Hg} 193 \mathrm{~m} 1$ & $\begin{array}{l}(\mathrm{n}, \mathrm{X} \backslash \mathrm{P})(\mathrm{n}, \mathrm{X} \backslash \mathrm{A})(\mathrm{n}, 2 \mathrm{~A})(\mathrm{n}, \mathrm{NDA} 2 \mathrm{NPA})(\mathrm{n}, \mathrm{PA})(\mathrm{n}, \mathrm{NA})(\mathrm{n}, \mathrm{N} 3 \mathrm{HE} \mathrm{A} \text { PT NPD) }(\mathrm{n}, \mathrm{P})(\mathrm{n}, \mathrm{P}) \\
(\mathrm{n}, \mathrm{N})(\mathrm{n}, \mathrm{G})\end{array}$ \\
\hline $80 \mathrm{Hg} 194$ & $(n, X \backslash P)(n, X \backslash A)(n, N A)(n, N 3 H E A$ PT) $(n, P)(n, P)(n, P)(n, G)(n, G)$ \\
\hline $80 \mathrm{Hg} 195$ & $(\mathrm{n}, \mathrm{X} \backslash \mathrm{P})(\mathrm{n}, \mathrm{X} \backslash \mathrm{A})(\mathrm{n}, 2 \mathrm{~A})(\mathrm{n}, \mathrm{NA})(\mathrm{n}, \mathrm{N} 3 \mathrm{HE} \mathrm{A} P \mathrm{PT})(\mathrm{n}, \mathrm{P})(\mathrm{n}, \mathrm{P})(\mathrm{n}, \mathrm{G})$ \\
\hline $80 \mathrm{Hg} 195 \mathrm{~m} 1$ & $(n, X \backslash P)(n, X \backslash A)(n, 2 A)(n, N A)(n, N 3 H E A P T)(n, P)(n, P)(n, N)(n, G)$ \\
\hline $80 \mathrm{Hg} 197$ & $(\mathrm{n}, \mathrm{X} \backslash \mathrm{P})(\mathrm{n}, \mathrm{X} \backslash \mathrm{A})(\mathrm{n}, \mathrm{NA})(\mathrm{n}, \mathrm{NA})(\mathrm{n}, \mathrm{N} 3 \mathrm{HE} \mathrm{A})(\mathrm{n}, \mathrm{P})(\mathrm{n}, \mathrm{P})(\mathrm{n}, \mathrm{G})$ \\
\hline $80 \mathrm{Hg} 197 \mathrm{~m} 1$ & $(\mathrm{n}, \mathrm{X} \backslash \mathrm{P})(\mathrm{n}, \mathrm{X} \backslash \mathrm{A})(\mathrm{n}, \mathrm{NA})(\mathrm{n}, \mathrm{NA})(\mathrm{n}, \mathrm{N} 3 \mathrm{HE} \mathrm{A})(\mathrm{n}, \mathrm{P})(\mathrm{n}, \mathrm{P})(\mathrm{n}, \mathrm{N})(\mathrm{n}, \mathrm{G})$ \\
\hline $80 \mathrm{Hg} 203$ & $(\mathrm{n}, \mathrm{X} \backslash \mathrm{A})(\mathrm{n}, \mathrm{N} 3 \mathrm{HE} \mathrm{A})(\mathrm{n}, \mathrm{G})$ \\
\hline $81 \mathrm{T1199}$ & $(\mathrm{n}, \mathrm{X} \backslash \mathrm{P})(\mathrm{n}, \mathrm{X} \backslash \mathrm{A})(\mathrm{n}, \mathrm{NA})(\mathrm{n}, \mathrm{NA})(\mathrm{n}, \mathrm{N} 3 \mathrm{HE} \mathrm{A})(\mathrm{n}, \mathrm{N} 3 \mathrm{HE} \mathrm{A})(\mathrm{n}, \mathrm{N} 3 \mathrm{HE} \mathrm{A})(\mathrm{n}, \mathrm{P})(\mathrm{n}, \mathrm{P})(\mathrm{n}, \mathrm{G})$ \\
\hline $81 \mathrm{~T} 1200$ & $(\mathrm{n}, \mathrm{X} \backslash \mathrm{P})(\mathrm{n}, \mathrm{X} \backslash \mathrm{A})(\mathrm{n}, \mathrm{NA})(\mathrm{n}, \mathrm{NA})(\mathrm{n}, \mathrm{NA})(\mathrm{n}, \mathrm{N} 3 \mathrm{HE} \mathrm{A})(\mathrm{n}, \mathrm{N} 3 \mathrm{HE} \mathrm{A})(\mathrm{n}, \mathrm{P})(\mathrm{n}, \mathrm{G})$ \\
\hline $81 \mathrm{~T} 1201$ & $(n, X \backslash P)(n, X \backslash A)(n, N A)(n, N A)(n, N 3 H E A)(n, N 3 H E A)(n, P)(n, G)$ \\
\hline $81 \mathrm{~T} 1202$ & $(n, X \backslash P)(n, X \backslash A)(n, N A)(n, N A)(n, N 3 H E A)(n, P)(n, G)$ \\
\hline $81 \mathrm{~T} 1203$ & $(n, X \backslash P)(n, X \backslash A)(n, N A)(n, N 3 H E A)(n, N 3 H E A)(n, P)(n, G)$ \\
\hline $81 \mathrm{~T} 1204$ & $(\mathrm{n}, \mathrm{X} \backslash \mathrm{P})(\mathrm{n}, \mathrm{X} \backslash \mathrm{A})(\mathrm{n}, \mathrm{NA})(\mathrm{n}, \mathrm{N} 3 \mathrm{HE} \mathrm{A})(\mathrm{n}, \mathrm{P})(\mathrm{n}, \mathrm{G})$ \\
\hline $81 \mathrm{~T} 1205$ & $(n, X \backslash P)(n, X \backslash A)(n, N A)(n, N 3 H E A)(n, G)(n, G)$ \\
\hline $82 \mathrm{~Pb} 200$ & $(n, X \backslash P)(n, X \backslash A)(n, N A)(n, N 3 H E A$ PT) $(n, N 3 H E$ A PT) $(n, P)(n, G)(n, G)$ \\
\hline $82 \mathrm{~Pb} 201$ & $(n, X \backslash P)(n, X \backslash A)(n, N A)(n, N A)(n, N 3 H E A P T)(n, P)(n, G)(n, G)$ \\
\hline $82 \mathrm{~Pb} 202$ & $(\mathrm{n}, \mathrm{X} \backslash \mathrm{P})(\mathrm{n}, \mathrm{X} \backslash \mathrm{A})(\mathrm{n}, \mathrm{NA})(\mathrm{n}, \mathrm{N} 3 \mathrm{HE} \mathrm{A})(\mathrm{n}, \mathrm{N} 3 \mathrm{HE} \mathrm{A})(\mathrm{n}, \mathrm{P})(\mathrm{n}, \mathrm{G})$ \\
\hline $82 \mathrm{~Pb} 203$ & $(n, X \backslash P)(n, X \backslash A)(n, N A)(n, N A)(n, N 3 H E A)(n, P)(n, G)(n, G)$ \\
\hline $82 \mathrm{~Pb} 205$ & $(\mathrm{n}, \mathrm{X} \backslash \mathrm{P})(\mathrm{n}, \mathrm{X} \backslash \mathrm{A})(\mathrm{n}, \mathrm{NA})(\mathrm{n}, \mathrm{N} 3 \mathrm{HE} \mathrm{A})(\mathrm{n}, \mathrm{P})(\mathrm{n}, \mathrm{G})$ \\
\hline $82 \mathrm{~Pb} 209$ & $(\mathrm{n}, \mathrm{X} \backslash \mathrm{A})(\mathrm{n}, \mathrm{NA})(\mathrm{n}, \mathrm{N} 3 \mathrm{HE} \mathrm{A})(\mathrm{n}, \mathrm{G})$ \\
\hline $82 \mathrm{~Pb} 210$ & $(n, X \backslash A)(n, N A)(n, N 3 H E A)(n, G)$ \\
\hline $82 \mathrm{~Pb} 212$ & $(\mathrm{n}, \mathrm{X} \backslash \mathrm{A})(\mathrm{n}, \mathrm{NA})(\mathrm{n}, \mathrm{N} 3 \mathrm{HE} \mathrm{A})(\mathrm{n}, \mathrm{G})$ \\
\hline 83Bi203 & $\begin{array}{l}(\mathrm{n}, \mathrm{X} \backslash \mathrm{P})(\mathrm{n}, \mathrm{X} \backslash \mathrm{D})(\mathrm{n}, \mathrm{X} \backslash \mathrm{A})(\mathrm{n}, 2 \mathrm{NPA})(\mathrm{n}, 2 \mathrm{NPA})(\mathrm{n}, \mathrm{DA})(\mathrm{n}, \mathrm{PA})(\mathrm{n}, \mathrm{PA})(\mathrm{n}, \mathrm{NA})(\mathrm{n}, \mathrm{N} 3 \mathrm{HE} \mathrm{A} \\
\mathrm{PT})(\mathrm{n}, \mathrm{NP})(\mathrm{n}, \mathrm{P})(\mathrm{n}, \mathrm{P})(\mathrm{n}, \mathrm{P})(\mathrm{n}, \mathrm{G})\end{array}$ \\
\hline 83Bi204 & $\begin{array}{l}(\mathrm{n}, \mathrm{X} \backslash \mathrm{P})(\mathrm{n}, \mathrm{X} \backslash \mathrm{D})(\mathrm{n}, \mathrm{X} \backslash \mathrm{A})(\mathrm{n}, \mathrm{NPA} \mathrm{DA})(\mathrm{n}, \mathrm{PA})(\mathrm{n}, \mathrm{NA})(\mathrm{n}, \mathrm{N} 3 \mathrm{HE} \text { A PT) }(\mathrm{n}, \mathrm{NP})(\mathrm{n}, \mathrm{NP}) \\
(\mathrm{n}, \mathrm{P})(\mathrm{n}, \mathrm{P})(\mathrm{n}, \mathrm{G})\end{array}$ \\
\hline 83Bi205 & $(\mathrm{n}, \mathrm{X} \backslash \mathrm{P})(\mathrm{n}, \mathrm{X} \backslash \mathrm{A})(\mathrm{n}, \mathrm{PA})(\mathrm{n}, \mathrm{NA})(\mathrm{n}, \mathrm{N} 3 \mathrm{HE} \mathrm{A} \mathrm{PT})(\mathrm{n}, \mathrm{P})(\mathrm{n}, \mathrm{P})(\mathrm{n}, \mathrm{G})$ \\
\hline 83Bi206 & $(\mathrm{n}, \mathrm{X} \backslash \mathrm{P})(\mathrm{n}, \mathrm{X} \backslash \mathrm{A})(\mathrm{n}, \mathrm{NA})(\mathrm{n}, \mathrm{N} 3 \mathrm{HE} \mathrm{A})(\mathrm{n}, \mathrm{P})(\mathrm{n}, \mathrm{G})$ \\
\hline
\end{tabular}




\begin{tabular}{|c|c|}
\hline Target Nucl. & Reactions \\
\hline 83Bi207 & $(n, X \backslash P)(n, X \backslash A)(n, N A)(n, N 3 H E A)(n, P)(n, P)(n, G)(n, G)$ \\
\hline 83Bi208 & $(n, X \backslash P)(n, X \backslash A)(n, N A)(n, N 3 H E A)(n, P)(n, G)$ \\
\hline $83 \mathrm{Bi} 210$ & $\begin{array}{l}(\mathrm{n}, \mathrm{X} \backslash \mathrm{P})(\mathrm{n}, \mathrm{X} \backslash \mathrm{T})(\mathrm{n}, \mathrm{X} \backslash \mathrm{A})(\mathrm{n}, \mathrm{NA})(\mathrm{n}, \mathrm{NA})(\mathrm{n}, \mathrm{N} 3 \mathrm{HE} \mathrm{A})(\mathrm{n}, \mathrm{N} 3 \mathrm{HE} \mathrm{A})(\mathrm{n}, \mathrm{ND} 2 \mathrm{NP} T)(\mathrm{n}, \mathrm{P}) \\
(\mathrm{n}, \mathrm{G})\end{array}$ \\
\hline 83Bi210m1 & $\begin{array}{l}(n, X \backslash P)(n, X \backslash T)(n, X \backslash A)(n, N A)(n, N A)(n, N 3 H E A)(n, N 3 H E A)(n, N D 2 N P T)(n, P) \\
(n, N)(n, G)\end{array}$ \\
\hline 84Po206 & 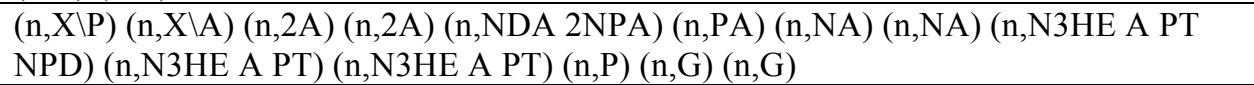 \\
\hline 84Po207 & $\begin{array}{l}(\mathrm{n}, \mathrm{X} \backslash \mathrm{P})(\mathrm{n}, \mathrm{X} \backslash 3 \mathrm{HE})(\mathrm{n}, \mathrm{X} \backslash \mathrm{A})(\mathrm{n}, 2 \mathrm{~A})(\mathrm{n}, \mathrm{PA})(\mathrm{n}, \mathrm{NA})(\mathrm{n}, \mathrm{NA})(\mathrm{n}, \mathrm{NA})(\mathrm{n}, \mathrm{N} 3 \mathrm{HE} \text { A PT NPD } \\
2 \mathrm{~N} 2 \mathrm{P})(\mathrm{n}, \mathrm{N} 3 \mathrm{HE} \text { A PT NPD 2N2P) (n,N2P PD) (n,N2P PD) (n,2P) }(\mathrm{n}, \mathrm{P})(\mathrm{n}, \mathrm{G})\end{array}$ \\
\hline $84 \mathrm{Po} 208$ & $\begin{array}{l}(\mathrm{n}, \mathrm{X} \backslash \mathrm{P})(\mathrm{n}, \mathrm{X} \backslash 3 \mathrm{HE})(\mathrm{n}, \mathrm{X} \backslash \mathrm{A})(\mathrm{n}, 2 \mathrm{~A})(\mathrm{n}, \mathrm{NDA} 2 \mathrm{2NA})(\mathrm{n}, \mathrm{PA})(\mathrm{n}, \mathrm{NA})(\mathrm{n}, \mathrm{NA})(\mathrm{n}, \mathrm{N} 3 \mathrm{HE} \mathrm{A} \\
\mathrm{PT} N \mathrm{NP})(\mathrm{n}, \mathrm{N} 3 \mathrm{HE} A \mathrm{PT})(\mathrm{n}, \mathrm{N} 2 \mathrm{P} P \mathrm{PD})(\mathrm{n}, \mathrm{P})(\mathrm{n}, \mathrm{P})(\mathrm{n}, \mathrm{G})\end{array}$ \\
\hline $84 \mathrm{Po} 209$ & $\begin{array}{l}(n, X \backslash P)(n, X \backslash 3 H E)(n, X \backslash A)(n, 2 A)(n, P A)(n, N A)(n, N A)(n, N 3 H E \text { A PT NPD 2N2P) } \\
(n, N 2 P \text { PD 3HE) (n,N2P PD) }(n, P)(n, G)\end{array}$ \\
\hline $84 \mathrm{Po} 210$ & $(n, X \backslash P)(n, X \backslash A)(n, N D A)(n, P A)(n, N A)(n, N 3 H E A)(n, N 3 H E A)(n, G)(n, G)$ \\
\hline $85 \mathrm{At} 210$ & $\begin{array}{l}(\mathrm{n}, \mathrm{X} \backslash \mathrm{P})(\mathrm{n}, \mathrm{X} \backslash \mathrm{D})(\mathrm{n}, \mathrm{X} \backslash \mathrm{A})(\mathrm{n}, 2 \mathrm{~A})(\mathrm{n}, \mathrm{TA} \text { NDA 2NPA) (n,TA NDA 2NPA) (n,NPA DA) } \\
(\mathrm{n}, \mathrm{NPA} \text { DA) (n,PA) (n,NA) (n,N3HE A PT NPD 2N2P) (n,NP) (n,P) (n,G) }\end{array}$ \\
\hline $85 \mathrm{At} 211$ & $\begin{array}{l}(\mathrm{n}, \mathrm{X} \backslash \mathrm{P})(\mathrm{n}, \mathrm{X} \backslash \mathrm{D})(\mathrm{n}, \mathrm{X} \backslash 3 \mathrm{HE})(\mathrm{n}, \mathrm{X} \backslash \mathrm{A})(\mathrm{n}, 2 \mathrm{~A})(\mathrm{n}, \mathrm{TA} N \mathrm{NA} 2 \mathrm{NPA})(\mathrm{n}, \mathrm{TA} \text { NDA 2NPA) } \\
(\mathrm{n}, \mathrm{NPA} D \mathrm{DA})(\mathrm{n}, \mathrm{PA})(\mathrm{n}, \mathrm{PA})(\mathrm{n}, \mathrm{NA})(\mathrm{n}, \mathrm{N} 3 \mathrm{HE} \text { A PT NPD) (n,N3HE A PT) (n,N2P PD) } \\
(\mathrm{n}, \mathrm{NP})(\mathrm{n}, \mathrm{P})(\mathrm{n}, \mathrm{P})(\mathrm{n}, \mathrm{G})(\mathrm{n}, \mathrm{G})\end{array}$ \\
\hline $86 \mathrm{Rn} 211$ & $\begin{array}{l}(\mathrm{n}, \mathrm{X} \backslash \mathrm{P})(\mathrm{n}, \mathrm{X} \backslash 3 \mathrm{HE})(\mathrm{n}, \mathrm{X} \backslash \mathrm{A})(\mathrm{n}, \mathrm{N} 2 \mathrm{~A})(\mathrm{n}, \mathrm{N} 2 \mathrm{~A})(\mathrm{n}, \mathrm{N} 2 \mathrm{~A})(\mathrm{n}, 2 \mathrm{~A})(\mathrm{n}, 2 \mathrm{~A})(\mathrm{n}, \mathrm{TA} \text { NDA } 2 \mathrm{NPA}) \\
(\mathrm{n}, \mathrm{NPA} \text { DA })(\mathrm{n}, \mathrm{PA})(\mathrm{n}, \mathrm{NA} N \mathrm{NPT})(\mathrm{n}, \mathrm{NA})(\mathrm{n}, \mathrm{N} 3 \mathrm{HE} \text { A PT NPD 2N2P) (n,N2P 3HE PD) } \\
(\mathrm{n}, 2 \mathrm{P})(\mathrm{n}, \mathrm{P})(\mathrm{n}, \mathrm{G})\end{array}$ \\
\hline $86 \mathrm{Rn} 222$ & $(\mathrm{n}, \mathrm{X} \backslash \mathrm{A})(\mathrm{n}, 2 \mathrm{~N} 2 \mathrm{~A})(\mathrm{n}, \mathrm{N} 2 \mathrm{~A})(\mathrm{n}, 2 \mathrm{NA})(\mathrm{n}, \mathrm{NA})(\mathrm{n}, \mathrm{N} 3 \mathrm{HE} \mathrm{A})(\mathrm{n}, \mathrm{G})$ \\
\hline $88 \mathrm{Ra} 228$ & $(\mathrm{n}, \mathrm{X} \backslash \mathrm{A})(\mathrm{n}, \mathrm{NA})(\mathrm{n}, \mathrm{N} 3 \mathrm{HE} \mathrm{A})(\mathrm{n}, \mathrm{G})$ \\
\hline $89 A c 228$ & $(n, X \backslash P)(n, X \backslash A)(n, 2 N A)(n, N A)(n, N 3 H E A)(n, P)(n, G)$ \\
\hline $91 \mathrm{~Pa} 228$ & $\begin{array}{l}(\mathrm{n}, \mathrm{X} \backslash \mathrm{P})(\mathrm{n}, \mathrm{X} \backslash \mathrm{A})(\mathrm{n}, \mathrm{N} 3 \mathrm{~A})(\mathrm{n}, 2 \mathrm{~N} 2 \mathrm{~A})(\mathrm{n}, \mathrm{N} 2 \mathrm{~A})(\mathrm{n}, 2 \mathrm{~A})(\mathrm{n}, \mathrm{TA} N \mathrm{ND} 2 \mathrm{NPA})(\mathrm{n}, \mathrm{NPA} \mathrm{DA}) \\
(\mathrm{n}, \mathrm{PA})(\mathrm{n}, 2 \mathrm{NA})(\mathrm{n}, \mathrm{NA})(\mathrm{n}, \mathrm{N} 3 \mathrm{HE} A)(\mathrm{n}, \mathrm{P})(\mathrm{n}, \mathrm{G})\end{array}$ \\
\hline $91 \mathrm{~Pa} 234$ & $(\mathrm{n}, \mathrm{X} \backslash \mathrm{P})(\mathrm{n}, \mathrm{X} \backslash \mathrm{A})(\mathrm{n}, \mathrm{NA})(\mathrm{n}, \mathrm{N} 3 \mathrm{HE} \mathrm{A})(\mathrm{n}, \mathrm{P})(\mathrm{n}, \mathrm{G})$ \\
\hline $93 \mathrm{~Np} 236 \mathrm{~m} 1$ & $(\mathrm{n}, \mathrm{X} \backslash \mathrm{P})(\mathrm{n}, \mathrm{X} \backslash \mathrm{A})(\mathrm{n}, \mathrm{NA})(\mathrm{n}, \mathrm{N} 3 \mathrm{HE} \mathrm{A})(\mathrm{n}, \mathrm{P})(\mathrm{n}, \mathrm{G})$ \\
\hline $94 \mathrm{Pu} 234$ & $(\mathrm{n}, \mathrm{X} \backslash \mathrm{P})(\mathrm{n}, \mathrm{X} \backslash \mathrm{A})(\mathrm{n}, 2 \mathrm{~N} 2 \mathrm{~A})(\mathrm{n}, \mathrm{N} 2 \mathrm{~A})(\mathrm{n}, 2 \mathrm{~A})(\mathrm{n}, \mathrm{NA})(\mathrm{n}, \mathrm{N} 3 \mathrm{HE} \mathrm{A})(\mathrm{n}, \mathrm{P})(\mathrm{n}, \mathrm{G})$ \\
\hline $94 \mathrm{Pu} 245$ & $(\mathrm{n}, \mathrm{X} \backslash \mathrm{A})(\mathrm{n}, 2 \mathrm{NA})(\mathrm{n}, \mathrm{NA})(\mathrm{n}, \mathrm{N} 3 \mathrm{HE} \mathrm{A})(\mathrm{n}, \mathrm{G})$ \\
\hline $94 \mathrm{Pu} 247$ & $(\mathrm{n}, \mathrm{X} \backslash \mathrm{A})(\mathrm{n}, \mathrm{NA})(\mathrm{n}, \mathrm{N} 3 \mathrm{HE} \mathrm{A})$ \\
\hline 95Am239 & $(\mathrm{n}, \mathrm{X} \backslash \mathrm{P})(\mathrm{n}, \mathrm{X} \backslash \mathrm{A})(\mathrm{n}, \mathrm{N} 2 \mathrm{~A})(\mathrm{n}, 2 \mathrm{~A})(\mathrm{n}, \mathrm{NA})(\mathrm{n}, \mathrm{N} 3 \mathrm{HE} \mathrm{A})(\mathrm{n}, \mathrm{N} 3 \mathrm{HE} \mathrm{A})(\mathrm{n}, \mathrm{P})(\mathrm{n}, \mathrm{G})$ \\
\hline $97 \mathrm{Bk} 248 \mathrm{~m} 1$ & $(\mathrm{n}, \mathrm{X} \backslash \mathrm{P})(\mathrm{n}, \mathrm{X} \backslash \mathrm{A})(\mathrm{n}, 2 \mathrm{~A})(\mathrm{n}, 2 \mathrm{NA})(\mathrm{n}, \mathrm{NA})(\mathrm{n}, \mathrm{NA})(\mathrm{n}, \mathrm{N} 3 \mathrm{HE} \mathrm{A})(\mathrm{n}, \mathrm{P})(\mathrm{n}, \mathrm{N})(\mathrm{n}, \mathrm{G})$ \\
\hline 99Es 250 & $(\mathrm{n}, \mathrm{X} \backslash \mathrm{P})(\mathrm{n}, \mathrm{X} \backslash \mathrm{T})(\mathrm{n}, \mathrm{X} \backslash \mathrm{A})(\mathrm{n}, \mathrm{PA})(\mathrm{n}, 2 \mathrm{NA})(\mathrm{n}, \mathrm{NA})(\mathrm{n}, \mathrm{N} 3 \mathrm{HE} \mathrm{A})(\mathrm{n}, \mathrm{ND} 2 \mathrm{NP})(\mathrm{n}, \mathrm{P})(\mathrm{n}, \mathrm{G})$ \\
\hline 99Es $256 \mathrm{~m} 1$ & $(\mathrm{n}, \mathrm{X} \backslash \mathrm{A})(\mathrm{n}, 2 \mathrm{NA})(\mathrm{n}, \mathrm{NA})(\mathrm{n}, \mathrm{A})(\mathrm{n}, \mathrm{G})$ \\
\hline 99Es257 & $(\mathrm{n}, \mathrm{X} \backslash \mathrm{A})(\mathrm{n}, 2 \mathrm{NA})(\mathrm{n}, \mathrm{NA})(\mathrm{n}, \mathrm{A})$ \\
\hline $100 \mathrm{Fm} 252$ & $\begin{array}{l}(\mathrm{n}, \mathrm{X} \backslash \mathrm{P})(\mathrm{n}, \mathrm{X} \backslash \mathrm{A})(\mathrm{n}, 2 \mathrm{~N} 2 \mathrm{~A})(\mathrm{n}, \mathrm{N} 2 \mathrm{~A})(\mathrm{n}, 2 \mathrm{~A})(\mathrm{n}, \mathrm{PA})(\mathrm{n}, \mathrm{PA})(\mathrm{n}, 2 \mathrm{NA})(\mathrm{n}, \mathrm{NA})(\mathrm{n}, \mathrm{N} 3 \mathrm{HE} \mathrm{A}) \\
(\mathrm{n}, \mathrm{P})(\mathrm{n}, \mathrm{G})\end{array}$ \\
\hline $100 \mathrm{Fm} 253$ & $\begin{array}{l}(\mathrm{n}, \mathrm{X} \backslash \mathrm{P})(\mathrm{n}, \mathrm{X} \backslash \mathrm{A})(\mathrm{n}, 2 \mathrm{~N} 2 \mathrm{~A})(\mathrm{n}, \mathrm{N} 2 \mathrm{~A})(\mathrm{n}, 2 \mathrm{~A})(\mathrm{n}, \mathrm{NPA} \mathrm{DA})(\mathrm{n}, \mathrm{NPA} \mathrm{DA})(\mathrm{n}, \mathrm{PA})(\mathrm{n}, 2 \mathrm{NA}) \\
(\mathrm{n}, \mathrm{NA})(\mathrm{n}, \mathrm{N} 3 \mathrm{HE} A)(\mathrm{n}, \mathrm{P})(\mathrm{n}, \mathrm{G})\end{array}$ \\
\hline $100 \mathrm{Fm} 257$ & $(n, X \backslash P)(n, X \backslash A)(n, 2 N A)(n, N A)(n, N 3 H E A)(n, P)(n, G)$ \\
\hline
\end{tabular}




\section{APPENDIX B.}

List of 1965 truncated reaction cross sections in the current CINDER2008 fusion-weighted library but fixed in the updated CINDER2008 fusion-weighted library.

\begin{tabular}{|c|c|}
\hline Target Nucl. & Reactions \\
\hline $4 \mathrm{Be} 7$ & $(\mathrm{~N}, \mathrm{X} \backslash \mathrm{P})(\mathrm{n}, \mathrm{X} \backslash \mathrm{A})(\mathrm{n}, \mathrm{P})(\mathrm{n}, \mathrm{G})$ \\
\hline $4 \mathrm{Be} 10$ & $(\mathrm{n}, \mathrm{G})$ \\
\hline $6 \mathrm{C} 12$ & $(n, G)$ \\
\hline $6 \mathrm{C} 13$ & $(\mathrm{n}, \mathrm{G})$ \\
\hline $6 \mathrm{C} 14$ & $(\mathrm{n}, \mathrm{G})$ \\
\hline $8 \mathrm{O} 18$ & $(\mathrm{n}, \mathrm{G})$ \\
\hline $10 \mathrm{Ne} 20$ & $(\mathrm{n}, \mathrm{G})$ \\
\hline $10 \mathrm{Ne} 21$ & $(\mathrm{n}, \mathrm{X} \backslash \mathrm{A})(\mathrm{n}, \mathrm{A})(\mathrm{n}, \mathrm{G})$ \\
\hline $10 \mathrm{Ne} 22$ & $(\mathrm{n}, \mathrm{G})$ \\
\hline $11 \mathrm{Na} 24$ & $(n, G)$ \\
\hline $12 \mathrm{Mg} 28$ & $(\mathrm{n}, \mathrm{G})$ \\
\hline $13 \mathrm{~A} 126$ & $(\mathrm{n}, \mathrm{X} \backslash \mathrm{P})(\mathrm{n}, \mathrm{X} \backslash \mathrm{A})(\mathrm{n}, \mathrm{N} 3 \mathrm{HE} \mathrm{A} \mathrm{PT})(\mathrm{n}, \mathrm{P})(\mathrm{n}, \mathrm{G})$ \\
\hline $14 \mathrm{Si} 31$ & $(n, G)$ \\
\hline 14Si32 & $(\mathrm{n}, \mathrm{G})$ \\
\hline $15 \mathrm{P} 32$ & $(\mathrm{n}, \mathrm{X} \backslash \mathrm{P})(\mathrm{n}, \mathrm{P})(\mathrm{n}, \mathrm{G})$ \\
\hline $15 \mathrm{P} 33$ & $(n, G)$ \\
\hline $16 \mathrm{~S} 35$ & $(\mathrm{n}, \mathrm{X} \backslash \mathrm{A})(\mathrm{n}, \mathrm{A})(\mathrm{n}, \mathrm{G})$ \\
\hline $17 \mathrm{Cl} 36$ & $(\mathrm{n}, \mathrm{X} \backslash \mathrm{P})(\mathrm{n}, \mathrm{X} \backslash \mathrm{A})(\mathrm{n}, \mathrm{A} \mathrm{PT})(\mathrm{n}, \mathrm{P})(\mathrm{n}, \mathrm{G})$ \\
\hline $18 \operatorname{Ar} 37$ & $(\mathrm{n}, \mathrm{X} \backslash \mathrm{P})(\mathrm{n}, \mathrm{X} \backslash \mathrm{A})(\mathrm{n}, \mathrm{N} 3 \mathrm{HE}$ A PT) $(\mathrm{n}, \mathrm{P})(\mathrm{n}, \mathrm{G})$ \\
\hline $18 \operatorname{Ar} 39$ & $(\mathrm{n}, \mathrm{X} \backslash \mathrm{A})(\mathrm{n}, \mathrm{A} P T)(\mathrm{n}, \mathrm{G})$ \\
\hline $18 \operatorname{Ar} 41$ & $(\mathrm{n}, \mathrm{G})$ \\
\hline $18 \operatorname{Ar} 42$ & $(n, G)$ \\
\hline $19 \mathrm{~K} 42$ & $(\mathrm{n}, \mathrm{X} \backslash \mathrm{P})(\mathrm{n}, \mathrm{P})(\mathrm{n}, \mathrm{G})$ \\
\hline $19 \mathrm{~K} 43$ & $(\mathrm{n}, \mathrm{G})$ \\
\hline $20 \mathrm{Ca} 41$ & $(\mathrm{n}, \mathrm{X} \backslash \mathrm{P})(\mathrm{n}, \mathrm{X} \backslash \mathrm{A})(\mathrm{n}, \mathrm{N} 3 \mathrm{HE}$ A PT) $(\mathrm{n}, \mathrm{P})(\mathrm{n}, \mathrm{G})$ \\
\hline $20 \mathrm{Ca} 45$ & $(n, G)$ \\
\hline $20 \mathrm{Ca} 47$ & $(\mathrm{n}, \mathrm{G})$ \\
\hline $21 \mathrm{Sc} 44 \mathrm{~m} 1$ & $(n, X \backslash P)(n, X \backslash A)(n, N 3 H E A$ PT $)(n, P)(n, N)(n, G)(n, G)$ \\
\hline $21 \mathrm{Sc} 46$ & $(\mathrm{n}, \mathrm{X} \backslash \mathrm{P})(\mathrm{n}, \mathrm{P})(\mathrm{n}, \mathrm{G})$ \\
\hline $21 \mathrm{Sc} 47$ & $(\mathrm{n}, \mathrm{G})$ \\
\hline $21 \mathrm{Sc} 48$ & $(n, X \backslash P)(n, P)(n, G)$ \\
\hline $22 \mathrm{Ti} 44$ & $(\mathrm{n}, \mathrm{X} \backslash \mathrm{P})(\mathrm{n}, \mathrm{X} \backslash \mathrm{A})(\mathrm{n}, \mathrm{A} P \mathrm{PT})(\mathrm{n}, \mathrm{P})(\mathrm{n}, \mathrm{P})(\mathrm{n}, \mathrm{G})$ \\
\hline $22 \mathrm{Ti45}$ & $(n, X \backslash P)(n, X \backslash A)(n, N 3 H E$ A PT) $(n, P)(n, P)(n, G)$ \\
\hline
\end{tabular}




\begin{tabular}{|c|c|}
\hline Target Nucl. & Reactions \\
\hline $23 \mathrm{~V} 48$ & $(\mathrm{n}, \mathrm{X} \backslash \mathrm{P})(\mathrm{n}, \mathrm{X} \backslash \mathrm{A})(\mathrm{n}, \mathrm{A})(\mathrm{n}, \mathrm{A})(\mathrm{n}, \mathrm{P})(\mathrm{n}, \mathrm{G})$ \\
\hline $23 \mathrm{~V} 49$ & $(\mathrm{n}, \mathrm{X} \backslash \mathrm{P})(\mathrm{n}, \mathrm{P})(\mathrm{n}, \mathrm{G})$ \\
\hline $24 \mathrm{Cr} 48$ & $(\mathrm{n}, \mathrm{X} \backslash \mathrm{P})(\mathrm{n}, \mathrm{X} \backslash \mathrm{A})(\mathrm{n}, \mathrm{A})(\mathrm{n}, \mathrm{P})(\mathrm{n}, \mathrm{G})$ \\
\hline $24 \mathrm{Cr} 51$ & $(n, X \backslash P)(n, X \backslash A)(n, A P T)(n, P)(n, G)$ \\
\hline $25 \mathrm{Mn} 52$ & $(n, X \backslash P)(n, X \backslash A)(n, A P T)(n, P)(n, G)$ \\
\hline $25 \mathrm{Mn} 53$ & $(n, X \backslash P)(n, P)(n, G)$ \\
\hline $25 \mathrm{Mn} 54$ & $(\mathrm{n}, \mathrm{X} \backslash \mathrm{P})(\mathrm{n}, \mathrm{X} \backslash \mathrm{A})(\mathrm{n}, \mathrm{A})(\mathrm{n}, \mathrm{P})(\mathrm{n}, \mathrm{G})$ \\
\hline $26 \mathrm{Fe} 52$ & $(\mathrm{n}, \mathrm{X} \backslash \mathrm{P})(\mathrm{n}, \mathrm{X} \backslash \mathrm{A})(\mathrm{n}, \mathrm{A} P \mathrm{PT})(\mathrm{n}, \mathrm{P})(\mathrm{n}, \mathrm{P})(\mathrm{n}, \mathrm{G})(\mathrm{n}, \mathrm{G})$ \\
\hline $26 \mathrm{Fe} 55$ & $(n, X \backslash P)(n, X \backslash A)(n, A$ PT $)(n, P)(n, G)$ \\
\hline $26 \mathrm{Fe} 60$ & $(n, G)$ \\
\hline $27 \operatorname{Co55}$ & $(\mathrm{n}, \mathrm{X} \backslash \mathrm{P})(\mathrm{n}, \mathrm{X} \backslash \mathrm{A})(\mathrm{n}, \mathrm{A})(\mathrm{n}, \mathrm{A})(\mathrm{n}, \mathrm{P})(\mathrm{n}, \mathrm{G})$ \\
\hline $27 \operatorname{Co56}$ & $(\mathrm{n}, \mathrm{X} \backslash \mathrm{P})(\mathrm{n}, \mathrm{X} \backslash \mathrm{A})(\mathrm{n}, \mathrm{N} 3 \mathrm{HE}$ A PT $)(\mathrm{n}, \mathrm{P})(\mathrm{n}, \mathrm{G})$ \\
\hline $27 \mathrm{Co57}$ & $(\mathrm{n}, \mathrm{X} \backslash \mathrm{P})(\mathrm{n}, \mathrm{X} \backslash \mathrm{A})(\mathrm{n}, \mathrm{A})(\mathrm{n}, \mathrm{P})(\mathrm{n}, \mathrm{G})(\mathrm{n}, \mathrm{G})$ \\
\hline $27 \mathrm{Co} 60$ & $(\mathrm{n}, \mathrm{X} \backslash \mathrm{P})(\mathrm{n}, \mathrm{P})(\mathrm{n}, \mathrm{N})(\mathrm{n}, \mathrm{G})$ \\
\hline $28 \mathrm{Ni} 56$ & $(\mathrm{n}, \mathrm{X} \backslash \mathrm{P})(\mathrm{n}, \mathrm{X} \backslash \mathrm{A})(\mathrm{n}, \mathrm{N} 3 \mathrm{HE} \mathrm{PT} \mathrm{A})(\mathrm{n}, \mathrm{P})(\mathrm{n}, \mathrm{G})$ \\
\hline $28 \mathrm{Ni} 57$ & $(\mathrm{n}, \mathrm{X} \backslash \mathrm{P})(\mathrm{n}, \mathrm{X} \backslash \mathrm{A})(\mathrm{n}, \mathrm{N} 3 \mathrm{HE}$ A PT) $(\mathrm{n}, \mathrm{P})(\mathrm{n}, \mathrm{G})$ \\
\hline $28 \mathrm{Ni} 63$ & $(n, G)$ \\
\hline $28 \mathrm{Ni} 66$ & $(n, G)$ \\
\hline $29 \mathrm{Cu} 64$ & $(\mathrm{n}, \mathrm{X} \backslash \mathrm{P})(\mathrm{n}, \mathrm{X} \backslash \mathrm{A})(\mathrm{n}, \mathrm{A})(\mathrm{n}, \mathrm{P})(\mathrm{n}, \mathrm{G})$ \\
\hline $29 \mathrm{Cu} 67$ & $(\mathrm{n}, \mathrm{G})(\mathrm{n}, \mathrm{G})$ \\
\hline $30 \mathrm{Zn} 62$ & $(\mathrm{n}, \mathrm{X} \backslash \mathrm{P})(\mathrm{n}, \mathrm{X} \backslash \mathrm{A})(\mathrm{n}, \mathrm{N} 3 \mathrm{HE} \mathrm{A} \mathrm{PT})(\mathrm{n}, \mathrm{P})(\mathrm{n}, \mathrm{G})$ \\
\hline $30 \mathrm{Zn} 69 \mathrm{~m} 1$ & $(\mathrm{n}, \mathrm{X} \backslash \mathrm{A})(\mathrm{n}, \mathrm{A})(\mathrm{n}, \mathrm{N})(\mathrm{n}, \mathrm{G})$ \\
\hline $30 \mathrm{Zn} 72$ & $(n, G)(n, G)(n, G)$ \\
\hline $31 \mathrm{Ga} 66$ & $(\mathrm{n}, \mathrm{X} \backslash \mathrm{P})(\mathrm{n}, \mathrm{X} \backslash \mathrm{A})(\mathrm{n}, \mathrm{N} 3 \mathrm{HE}$ A PT) $(\mathrm{n}, \mathrm{P})(\mathrm{n}, \mathrm{G})$ \\
\hline $31 \mathrm{Ga} 67$ & $(n, X \backslash P)(n, X \backslash A)(n, A$ PT $)(n, P)(n, G)$ \\
\hline $31 \mathrm{Ga} 72$ & $(\mathrm{n}, \mathrm{X} \backslash \mathrm{P})(\mathrm{n}, \mathrm{X} \backslash \mathrm{A})(\mathrm{n}, \mathrm{PA})(\mathrm{n}, \mathrm{A})(\mathrm{n}, \mathrm{P})(\mathrm{n}, \mathrm{G})$ \\
\hline $32 \mathrm{Ge} 68$ & $(n, X \backslash P)(n, X \backslash A)(n, A$ PT $)(n, P)(n, G)$ \\
\hline $32 \mathrm{Ge} 69$ & $(\mathrm{n}, \mathrm{X} \backslash \mathrm{P})(\mathrm{n}, \mathrm{X} \backslash \mathrm{A})(\mathrm{n}, \mathrm{N} 3 \mathrm{HE}$ A PT) $(\mathrm{n}, \mathrm{P})(\mathrm{n}, \mathrm{G})$ \\
\hline $32 \mathrm{Ge} 71$ & $(\mathrm{n}, \mathrm{X} \backslash \mathrm{P})(\mathrm{n}, \mathrm{X} \backslash \mathrm{A})(\mathrm{n}, \mathrm{N} 3 \mathrm{HE}$ A PT) $(\mathrm{n}, \mathrm{P})(\mathrm{n}, \mathrm{G})$ \\
\hline $32 \mathrm{Ge} 77$ & $(n, G)$ \\
\hline 33 As71 & $(n, X \backslash P)(n, X \backslash A)(n, A$ PT) $(n, P)(n, P)(n, G)$ \\
\hline 33 As 72 & $(\mathrm{n}, \mathrm{X} \backslash \mathrm{P})(\mathrm{n}, \mathrm{X} \backslash \mathrm{A})(\mathrm{n}, \mathrm{N} 3 \mathrm{HE}$ A PT $)(\mathrm{n}, \mathrm{P})(\mathrm{n}, \mathrm{G})$ \\
\hline 33 As73 & $(\mathrm{n}, \mathrm{X} \backslash \mathrm{P})(\mathrm{n}, \mathrm{X} \backslash \mathrm{A})(\mathrm{n}, \mathrm{A})(\mathrm{n}, \mathrm{P})(\mathrm{n}, \mathrm{P})(\mathrm{n}, \mathrm{G})$ \\
\hline 33 As76 & $(\mathrm{n}, \mathrm{X} \backslash \mathrm{P})(\mathrm{n}, \mathrm{X} \backslash \mathrm{A})(\mathrm{n}, \mathrm{A})(\mathrm{n}, \mathrm{P})(\mathrm{n}, \mathrm{G})$ \\
\hline 33 As77 & $(n, G)$ \\
\hline $34 \mathrm{Se} 72$ & $(n, X \backslash P)(n, X \backslash A)(n, A$ PT) $(n, P)(n, G)(n, G)$ \\
\hline $34 \mathrm{Se} 73$ & $(n, X \backslash P)(n, X \backslash A)(n, N 3 H E$ A PT) $(n, P)(n, N)(n, G)$ \\
\hline $34 \mathrm{Se} 75$ & $(\mathrm{n}, \mathrm{X} \backslash \mathrm{P})(\mathrm{n}, \mathrm{X} \backslash \mathrm{A})(\mathrm{n}, \mathrm{N} 3 \mathrm{HE}$ A PT) $(\mathrm{n}, \mathrm{P})(\mathrm{n}, \mathrm{G})$ \\
\hline
\end{tabular}




\begin{tabular}{|c|c|}
\hline Target Nucl. & Reactions \\
\hline $35 \mathrm{Br} 76$ & $(n, X \backslash P)(n, X \backslash A)(n, N 3 H E A$ PT $)(n, P)(n, N)(n, G)(n, G)$ \\
\hline $35 \mathrm{Br} 77$ & $(n, X \backslash P)(n, X \backslash A)(n, A)(n, P)(n, P)(n, N)(n, G)$ \\
\hline $35 \mathrm{Br} 82$ & $(\mathrm{n}, \mathrm{X} \backslash \mathrm{P})(\mathrm{n}, \mathrm{P})(\mathrm{n}, \mathrm{N})(\mathrm{n}, \mathrm{G})$ \\
\hline $36 \mathrm{Kr} 76$ & $(n, X \backslash P)(n, X \backslash A)(n, A$ PT) $(n, A$ PT $)(n, P)(n, P)(n, G)$ \\
\hline $36 \mathrm{Kr} 79$ & $(n, X \backslash P)(n, X \backslash A)(n, N 3 H E A$ PT) $(n, P)(n, P)(n, N)(n, G)$ \\
\hline $36 \mathrm{Kr} 81$ & $(n, X \backslash P)(n, X \backslash A)(n, A$ PT) $(n, P)(n, G)$ \\
\hline $37 \mathrm{Rb} 82 \mathrm{~m} 1$ & $(n, X \backslash P)(n, X \backslash A)(n, A$ PT) $(n, A$ PT $)(n, P)(n, G)$ \\
\hline $37 \mathrm{Rb} 83$ & $(n, X \backslash P)(n, P)(n, P)(n, G)(n, G)$ \\
\hline $37 \mathrm{Rb} 84$ & $(\mathrm{n}, \mathrm{X} \backslash \mathrm{P})(\mathrm{n}, \mathrm{X} \backslash 3 \mathrm{HE})(\mathrm{n}, \mathrm{X} \backslash \mathrm{A})(\mathrm{n}, \mathrm{A})(\mathrm{n}, 3 \mathrm{HE})(\mathrm{n}, \mathrm{P})(\mathrm{n}, \mathrm{G})$ \\
\hline $38 \mathrm{Sr} 82$ & $(\mathrm{n}, \mathrm{X} \backslash \mathrm{P})(\mathrm{n}, \mathrm{X} \backslash \mathrm{A})(\mathrm{n}, \mathrm{A})(\mathrm{n}, \mathrm{A})(\mathrm{n}, \mathrm{P})(\mathrm{n}, \mathrm{P})(\mathrm{n}, \mathrm{G})(\mathrm{n}, \mathrm{G})$ \\
\hline $38 \mathrm{Sr} 83$ & $(n, X \backslash P)(n, X \backslash A)(n, N 3 H E$ A PT) $(n, P)(n, G)$ \\
\hline $38 \mathrm{Sr} 85$ & $(\mathrm{n}, \mathrm{X} \backslash \mathrm{P})(\mathrm{n}, \mathrm{X} \backslash \mathrm{A})(\mathrm{n}, \mathrm{A} \mathrm{PT})(\mathrm{n}, \mathrm{P})(\mathrm{n}, \mathrm{G})$ \\
\hline $38 \mathrm{Sr} 91$ & $(\mathrm{n}, \mathrm{G})$ \\
\hline $39 Y 86$ & $(n, X \backslash P)(n, X \backslash A)(n, A$ PT) $(n, P)(n, G)(n, G)$ \\
\hline $39 Y 87$ & $(\mathrm{n}, \mathrm{X} \backslash \mathrm{P})(\mathrm{n}, \mathrm{P})(\mathrm{n}, \mathrm{P})(\mathrm{n}, \mathrm{G})$ \\
\hline $39 \mathrm{Y} 87 \mathrm{~m} 1$ & $(n, X \backslash P)(n, X \backslash A)(n, A)(n, P)(n, P)(n, N)(n, G)$ \\
\hline $39 Y 88$ & $(\mathrm{n}, \mathrm{X} \backslash \mathrm{P})(\mathrm{n}, \mathrm{X} \backslash \mathrm{A})(\mathrm{n}, \mathrm{A})(\mathrm{n}, \mathrm{P})(\mathrm{n}, \mathrm{G})(\mathrm{n}, \mathrm{G})$ \\
\hline $39 Y 93$ & $(n, G)$ \\
\hline $40 \mathrm{Zr} 86$ & $(n, X \backslash P)(n, X \backslash A)(n, A) P T)(n, A)(n, P)(n, P)(n, G)(n, G)$ \\
\hline $40 \mathrm{Zr} 88$ & $(n, X \backslash P)(n, X \backslash A)(n, A)(n, A)(n, P)(n, G)(n, G)$ \\
\hline 40Zr89 & $(n, X \backslash P)(n, X \backslash A)(n, A$ PT) $(n, P)(n, P)(n, G)(n, G)$ \\
\hline 40Zr97 & $(n, G)$ \\
\hline $41 \mathrm{Nb} 90$ & $(\mathrm{n}, \mathrm{X} \backslash \mathrm{P})(\mathrm{n}, \mathrm{X} \backslash \mathrm{A})(\mathrm{n}, \mathrm{A}$ PT) $(\mathrm{n}, \mathrm{A} \mathrm{PT})(\mathrm{n}, \mathrm{P})(\mathrm{n}, \mathrm{P})(\mathrm{n}, \mathrm{N})(\mathrm{n}, \mathrm{G})$ \\
\hline $41 \mathrm{Nb} 91$ & $(n, X \backslash P)(n, X \backslash A)(n, A)(n, P)(n, N)(n, G)(n, G)$ \\
\hline $41 \mathrm{Nb} 91 \mathrm{~m} 1$ & $(n, X \backslash P)(n, X \backslash A)(n, A)(n, P)(n, N)(n, G)(n, G)$ \\
\hline $41 \mathrm{Nb92}$ & $(\mathrm{n}, \mathrm{X} \backslash \mathrm{P})(\mathrm{n}, \mathrm{X} \backslash \mathrm{A})(\mathrm{n}, \mathrm{N} 3 \mathrm{HE}$ A PT) $(\mathrm{n}, \mathrm{N} 3 \mathrm{HE}$ A PT) $(\mathrm{n}, \mathrm{P})(\mathrm{n}, \mathrm{N})(\mathrm{n}, \mathrm{G})(\mathrm{n}, \mathrm{G})$ \\
\hline $41 \mathrm{Nb} 92 \mathrm{~m} 1$ & $(n, X \backslash P)(n, X \backslash A)(n, P A)(n, N 3 H E$ A PT) $(n, N 3 H E A P T)(n, P)(n, N)(n, G)(n, G)$ \\
\hline $41 \mathrm{Nb} 93 \mathrm{~m} 1$ & $(\mathrm{n}, \mathrm{X} \backslash \mathrm{P})(\mathrm{n}, \mathrm{X} \backslash \mathrm{A})(\mathrm{n}, \mathrm{A})(\mathrm{n}, \mathrm{A})(\mathrm{n}, \mathrm{P})(\mathrm{n}, \mathrm{N})(\mathrm{n}, \mathrm{G})(\mathrm{n}, \mathrm{G})$ \\
\hline $41 \mathrm{Nb} 95 \mathrm{~m} 1$ & $(\mathrm{n}, \mathrm{X} \backslash \mathrm{P})(\mathrm{n}, \mathrm{X} \backslash \mathrm{A})(\mathrm{n}, \mathrm{A})(\mathrm{n}, \mathrm{P})(\mathrm{n}, \mathrm{N})(\mathrm{n}, \mathrm{G})$ \\
\hline $41 \mathrm{Nb} 96$ & $(\mathrm{n}, \mathrm{X} \backslash \mathrm{A})(\mathrm{n}, \mathrm{A})(\mathrm{n}, \mathrm{A})(\mathrm{n}, \mathrm{G})(\mathrm{n}, \mathrm{G})$ \\
\hline 42Mo93 & $(n, X \backslash P)(n, X \backslash A)(n, N 3 H E$ A PT) $(n, A$ PT) $(n, P)(n, P)(n, G)$ \\
\hline $42 \mathrm{Mo} 93 \mathrm{~m} 1$ & $(n, X \backslash P)(n, X \backslash A)(n, N 3 H E$ A PT) $(n, N 3 H E$ A PT) $(n, P)(n, P)(n, G)$ \\
\hline $43 \mathrm{Tc} 95$ & $(n, X \backslash P)(n, X \backslash A)(n, A$ PT) $(n, A$ PT) $(n, P)(n, N)(n, G)(n, G)$ \\
\hline $43 \mathrm{Tc} 95 \mathrm{~m} 1$ & $(n, X \backslash P)(n, X \backslash A)(n, A$ PT) $(n, A$ PT) $(n, P)(n, N)(n, G)(n, G)$ \\
\hline $43 \mathrm{Tc} 96$ & $(n, X \backslash P)(n, X \backslash A)(n, N 3 H E$ A PT) $(n, N 3 H E$ A PT) $(n, P)(n, N)(n, G)(n, G)$ \\
\hline $43 \mathrm{Tc} 97$ & $(n, X \backslash P)(n, X \backslash A)(n, A)(n, A)(n, P)(n, N)(n, G)$ \\
\hline $43 \mathrm{Tc} 97 \mathrm{~m} 1$ & $(n, X \backslash P)(n, X \backslash A)(n, A)(n, A)(n, P)(n, N)(n, G)$ \\
\hline $43 \mathrm{Tc} 98$ & $(n, X \backslash P)(n, X \backslash A)(n, A)(n, A)(n, P)(n, G)(n, G)$ \\
\hline
\end{tabular}




\begin{tabular}{|c|c|}
\hline Target Nucl. & Reactions \\
\hline $43 \mathrm{Tc} 99 \mathrm{~m} 1$ & $(\mathrm{n}, \mathrm{X} \backslash \mathrm{A})(\mathrm{n}, \mathrm{A})(\mathrm{n}, \mathrm{G})$ \\
\hline 44Ru97 & $(\mathrm{n}, \mathrm{X} \backslash \mathrm{P})(\mathrm{n}, \mathrm{X} \backslash \mathrm{A})(\mathrm{n}, \mathrm{N} 3 \mathrm{HE} \mathrm{A}$ PT) $(\mathrm{n}, \mathrm{P})(\mathrm{n}, \mathrm{P})(\mathrm{n}, \mathrm{G})$ \\
\hline 45Rh99 & $(\mathrm{n}, \mathrm{X} \backslash \mathrm{P})(\mathrm{n}, \mathrm{X} \backslash \mathrm{A})(\mathrm{n}, \mathrm{A} P \mathrm{PT})(\mathrm{n}, \mathrm{A} \mathrm{PT})(\mathrm{n}, \mathrm{P})(\mathrm{n}, \mathrm{N})(\mathrm{n}, \mathrm{G})(\mathrm{n}, \mathrm{G})$ \\
\hline 45Rh99m1 & $(\mathrm{n}, \mathrm{X} \backslash \mathrm{P})(\mathrm{n}, \mathrm{X} \backslash \mathrm{A})(\mathrm{n}, \mathrm{A}$ PT) $(\mathrm{n}, \mathrm{A}$ PT) $(\mathrm{n}, \mathrm{P})(\mathrm{n}, \mathrm{N})(\mathrm{n}, \mathrm{G})(\mathrm{n}, \mathrm{G})$ \\
\hline 45Rh100 & $(\mathrm{n}, \mathrm{X} \backslash \mathrm{P})(\mathrm{n}, \mathrm{X} \backslash \mathrm{A})(\mathrm{n}, \mathrm{N} 3 \mathrm{HE}$ A PT) $(\mathrm{n}, \mathrm{N} 3 \mathrm{HE}$ A PT) $(\mathrm{n}, \mathrm{P})(\mathrm{n}, \mathrm{N})(\mathrm{n}, \mathrm{G})(\mathrm{n}, \mathrm{G})$ \\
\hline 45Rh101 & $(n, X \backslash P)(n, X \backslash A)(n, A)(n, P)(n, G)(n, G)$ \\
\hline $45 \mathrm{Rh} 101 \mathrm{~m} 1$ & $(n, X \backslash P)(n, X \backslash A)(n, A)(n, P)(n, N)(n, G)(n, G)$ \\
\hline 45Rh102 & $(n, X \backslash P)(n, X \backslash 3 H E)(n, X \backslash A)(n, A)(n, A)(n, 3 H E P D)(n, P)(n, N)(n, G)(n, G)$ \\
\hline 45Rh102m1 & $(\mathrm{n}, \mathrm{X} \backslash \mathrm{P})(\mathrm{n}, \mathrm{X} \backslash 3 \mathrm{HE})(\mathrm{n}, \mathrm{X} \backslash \mathrm{A})(\mathrm{n}, 2 \mathrm{NA})(\mathrm{n}, \mathrm{A})(\mathrm{n}, \mathrm{A})(\mathrm{n}, 3 \mathrm{HE} \mathrm{PD})(\mathrm{n}, \mathrm{P})(\mathrm{n}, \mathrm{N})(\mathrm{n}, \mathrm{G})(\mathrm{n}, \mathrm{G})$ \\
\hline $46 \mathrm{Pd} 100$ & $(n, X \backslash P)(n, X \backslash A)(n, N 3 H E$ A PT) $(n, P)(n, P)(n, G)$ \\
\hline 46Pd101 & $(n, X \backslash P)(n, X \backslash A)(n, N 3 H E$ A PT) $(n, P)(n, P)(n, G)$ \\
\hline 46Pd103 & $(n, X \backslash P)(n, X \backslash A)(n, N 3 H E$ A PT) $(n, P)(n, P)(n, G)$ \\
\hline $46 \mathrm{Pd} 109$ & $(\mathrm{n}, \mathrm{X} \backslash \mathrm{A})(\mathrm{n}, \mathrm{A})(\mathrm{n}, \mathrm{G})$ \\
\hline $46 \mathrm{Pd} 112$ & $(\mathrm{n}, \mathrm{G})(\mathrm{n}, \mathrm{G})$ \\
\hline $47 \mathrm{Ag} 105$ & $(\mathrm{n}, \mathrm{X} \backslash \mathrm{P})(\mathrm{n}, \mathrm{X} \backslash \mathrm{A})(\mathrm{n}, \mathrm{A})(\mathrm{n}, \mathrm{A})(\mathrm{n}, \mathrm{P})(\mathrm{n}, \mathrm{N})(\mathrm{n}, \mathrm{G})(\mathrm{n}, \mathrm{G})$ \\
\hline 47Ag106m1 & $(n, X \backslash P)(n, X \backslash A)(n, A$ PT $)(n, A)(n, P)(n, N)(n, G)(n, G)$ \\
\hline 47Ag108m1 & $(n, X \backslash P)(n, X \backslash A)(n, A)(n, A)(n, P)(n, N)(n, G)(n, G)$ \\
\hline $48 \mathrm{Cd} 107$ & $(n, X \backslash P)(n, X \backslash A)(n, N 3 H E$ A PT) $(n, P)(n, P)(n, G)$ \\
\hline $48 \mathrm{Cd} 109$ & $(\mathrm{n}, \mathrm{X} \backslash \mathrm{P})(\mathrm{n}, \mathrm{X} \backslash \mathrm{A})(\mathrm{n}, \mathrm{A} P \mathrm{PT})(\mathrm{n}, \mathrm{P})(\mathrm{n}, \mathrm{P})(\mathrm{n}, \mathrm{G})$ \\
\hline $48 \mathrm{Cd} 113 \mathrm{~m} 1$ & $(\mathrm{n}, \mathrm{X} \backslash \mathrm{A})(\mathrm{n}, \mathrm{A})(\mathrm{n}, \mathrm{N})(\mathrm{n}, \mathrm{G})$ \\
\hline $48 \mathrm{Cd} 115$ & $(\mathrm{n}, \mathrm{X} \backslash \mathrm{A})(\mathrm{n}, \mathrm{A})(\mathrm{n}, \mathrm{G})$ \\
\hline 49In111 & $(n, X \backslash P)(n, X \backslash A)(n, A)(n, A)(n, P)(n, P)(n, G)$ \\
\hline 49In114m1 & $(n, X \backslash P)(n, X \backslash A)(n, A)(n, A)(n, P)(n, N)(n, G)(n, G)$ \\
\hline $50 \mathrm{Sn} 117 \mathrm{~m} 1$ & $(\mathrm{n}, \mathrm{X} \backslash \mathrm{A})(\mathrm{n}, \mathrm{A})(\mathrm{n}, \mathrm{N})(\mathrm{n}, \mathrm{G})$ \\
\hline $50 \mathrm{Sn} 119 \mathrm{~m} 1$ & $(\mathrm{n}, \mathrm{X} \backslash \mathrm{A})(\mathrm{n}, \mathrm{A})(\mathrm{n}, \mathrm{N})(\mathrm{n}, \mathrm{G})$ \\
\hline $50 \mathrm{Sn} 121$ & $(\mathrm{n}, \mathrm{N})(\mathrm{n}, \mathrm{G})$ \\
\hline $50 \mathrm{Sn} 121 \mathrm{~m} 1$ & $(\mathrm{n}, \mathrm{N})(\mathrm{n}, \mathrm{G})$ \\
\hline 51Sb119 & $(\mathrm{n}, \mathrm{X} \backslash \mathrm{P})(\mathrm{n}, \mathrm{X} \backslash \mathrm{A})(\mathrm{n}, \mathrm{A})(\mathrm{n}, \mathrm{A})(\mathrm{n}, \mathrm{A})(\mathrm{n}, \mathrm{P})(\mathrm{n}, \mathrm{P})(\mathrm{n}, \mathrm{G})(\mathrm{n}, \mathrm{G})$ \\
\hline $51 \mathrm{Sb} 120 \mathrm{~m} 1$ & $(n, X \backslash P)(n, X \backslash A)(n, A)(n, A)(n, P)(n, N)(n, G)$ \\
\hline $51 \mathrm{Sb} 122$ & $(\mathrm{n}, \mathrm{X} \backslash \mathrm{P})(\mathrm{n}, \mathrm{X} \backslash \mathrm{A})(\mathrm{n}, \mathrm{A})(\mathrm{n}, \mathrm{A})(\mathrm{n}, \mathrm{P})(\mathrm{n}, \mathrm{G})$ \\
\hline $51 \mathrm{Sb} 127$ & $(\mathrm{n}, \mathrm{G})(\mathrm{n}, \mathrm{G})$ \\
\hline $51 \mathrm{Sb} 128$ & $(n, G)(n, G)$ \\
\hline $52 \mathrm{Te} 118$ & $(n, X \backslash P)(n, X \backslash A)(n, N 3 H E$ A PT) $(n, P)(n, G)(n, G)$ \\
\hline $52 \mathrm{Te} 119$ & $(n, X \backslash P)(n, X \backslash A)(n, N 3 H E$ A PT) $(n, P)(n, P)(n, G)$ \\
\hline $52 \mathrm{Te} 119 \mathrm{~m} 1$ & $(n, X \backslash P)(n, X \backslash A)(n, N 3 H E A$ PT $)(n, P)(n, P)(n, N)(n, G)$ \\
\hline $52 \mathrm{Te} 121$ & $(\mathrm{n}, \mathrm{X} \backslash \mathrm{P})(\mathrm{n}, \mathrm{X} \backslash \mathrm{A})(\mathrm{n}, \mathrm{N} 3 \mathrm{HE} \mathrm{A} \mathrm{PT})(\mathrm{n}, \mathrm{P})(\mathrm{n}, \mathrm{G})$ \\
\hline $52 \mathrm{Te} 121 \mathrm{~m} 1$ & $(\mathrm{n}, \mathrm{X} \backslash \mathrm{P})(\mathrm{n}, \mathrm{X} \backslash \mathrm{A})(\mathrm{n}, \mathrm{N} 3 \mathrm{HE}$ A PT) $(\mathrm{n}, \mathrm{P})(\mathrm{n}, \mathrm{N})(\mathrm{n}, \mathrm{G})$ \\
\hline $52 \mathrm{Te} 123 \mathrm{~m} 1$ & $(\mathrm{n}, \mathrm{X} \backslash \mathrm{P})(\mathrm{n}, \mathrm{X} \backslash \mathrm{A})(\mathrm{n}, \mathrm{A} P \mathrm{PT})(\mathrm{n}, \mathrm{P})(\mathrm{n}, \mathrm{N})(\mathrm{n}, \mathrm{G})$ \\
\hline
\end{tabular}




\begin{tabular}{|c|c|}
\hline Target Nucl. & Reactions \\
\hline $52 \mathrm{Te} 125 \mathrm{~m} 1$ & $(\mathrm{n}, \mathrm{X} \backslash \mathrm{A})(\mathrm{n}, \mathrm{A})(\mathrm{n}, \mathrm{N})(\mathrm{n}, \mathrm{G})$ \\
\hline $52 \mathrm{Te} 127$ & $(\mathrm{n}, \mathrm{X} \backslash \mathrm{A})(\mathrm{n}, \mathrm{A})(\mathrm{n}, \mathrm{N})(\mathrm{n}, \mathrm{G})$ \\
\hline $52 \mathrm{Te} 129$ & $(\mathrm{n}, \mathrm{X} \backslash \mathrm{A})(\mathrm{n}, \mathrm{A})(\mathrm{n}, \mathrm{N})(\mathrm{n}, \mathrm{G})$ \\
\hline $52 \mathrm{Te} 131 \mathrm{~m} 1$ & $(\mathrm{n}, \mathrm{N})(\mathrm{n}, \mathrm{G})$ \\
\hline $53 \mathrm{I} 123$ & $(n, X \backslash P)(n, X \backslash A)(n, A)(n, A)(n, P)(n, P)(n, G)$ \\
\hline $53 \mathrm{II} 124$ & $(n, X \backslash P)(n, X \backslash A)(n, N 3 H E$ A PT) $(n, P)(n, G)$ \\
\hline $53 \mathrm{II} 125$ & $(\mathrm{n}, \mathrm{X} \backslash \mathrm{P})(\mathrm{n}, \mathrm{X} \backslash 3 \mathrm{HE})(\mathrm{n}, \mathrm{X} \backslash \mathrm{A})(\mathrm{n}, \mathrm{A})(\mathrm{n}, \mathrm{A})(\mathrm{n}, 3 \mathrm{HE} \mathrm{PD})(\mathrm{n}, \mathrm{P})(\mathrm{n}, \mathrm{P})(\mathrm{n}, \mathrm{G})$ \\
\hline $53 \mathrm{II} 126$ & $(\mathrm{n}, \mathrm{X} \backslash \mathrm{P})(\mathrm{n}, \mathrm{X} \backslash \mathrm{A})(\mathrm{n}, \mathrm{A})(\mathrm{n}, \mathrm{P})(\mathrm{n}, \mathrm{G})$ \\
\hline $53 \mathrm{II} 128$ & $(\mathrm{n}, \mathrm{X} \backslash \mathrm{P})(\mathrm{n}, \mathrm{X} \backslash \mathrm{A})(\mathrm{n}, \mathrm{A})(\mathrm{n}, \mathrm{P})(\mathrm{n}, \mathrm{G})$ \\
\hline $53 \mathrm{II} 133$ & $(n, G)(n, G)$ \\
\hline $54 \mathrm{Xe} 122$ & $(n, X \backslash P)(n, X \backslash A)(n, A$ PT) $(n, A$ PT $)(n, P)(n, G)$ \\
\hline $54 \mathrm{Xe} 125$ & $(\mathrm{n}, \mathrm{X} \backslash \mathrm{P})(\mathrm{n}, \mathrm{X} \backslash \mathrm{A})(\mathrm{n}, \mathrm{N} 3 \mathrm{HE}$ A PT $)(\mathrm{n}, \mathrm{P})(\mathrm{n}, \mathrm{G})$ \\
\hline $54 \mathrm{Xe} 127$ & $(n, X \backslash P)(n, X \backslash A)(n, A$ PT) $(n, 3 H E P D)(n, P)(n, G)$ \\
\hline $54 \mathrm{Xe} 129 \mathrm{~m} 1$ & $(\mathrm{n}, \mathrm{X} \backslash \mathrm{P})(\mathrm{n}, \mathrm{X} \backslash \mathrm{A})(\mathrm{n}, \mathrm{A})(\mathrm{n}, \mathrm{P})(\mathrm{n}, \mathrm{N})(\mathrm{n}, \mathrm{G})$ \\
\hline $54 \mathrm{Xe} 131 \mathrm{~m} 1$ & $(\mathrm{n}, \mathrm{X} \backslash \mathrm{P})(\mathrm{n}, \mathrm{X} \backslash \mathrm{A})(\mathrm{n}, \mathrm{A})(\mathrm{n}, \mathrm{P})(\mathrm{n}, \mathrm{N})(\mathrm{n}, \mathrm{G})$ \\
\hline $54 \mathrm{Xe} 133 \mathrm{~m} 1$ & $(n, X \backslash A)(n, A)(n, N)(n, G)(n, G)$ \\
\hline $55 \mathrm{Cs} 127$ & $(n, X \backslash P)(n, X \backslash A)(n, A)(n, P)(n, P)(n, G)$ \\
\hline $55 \mathrm{Cs} 129$ & $(n, X \backslash P)(n, X \backslash A)(n, P A)(n, A)(n, P)(n, P)(n, G)(n, G)$ \\
\hline $55 \mathrm{Cs} 131$ & $(n, X \backslash P)(n, X \backslash A)(n, A)(n, P)(n, P)(n, G)$ \\
\hline $55 \mathrm{Cs} 132$ & $(\mathrm{n}, \mathrm{X} \backslash \mathrm{P})(\mathrm{n}, \mathrm{X} \backslash \mathrm{A})(\mathrm{n}, \mathrm{A})(\mathrm{n}, \mathrm{P})(\mathrm{n}, \mathrm{G})$ \\
\hline $56 \mathrm{Ba} 128$ & $(n, X \backslash P)(n, X \backslash A)(n, A$ PT) $(n, A$ PT $)(n, P)(n, G)(n, G)$ \\
\hline $56 \mathrm{Ba} 129$ & $(n, X \backslash P)(n, X \backslash A)(n, N 3 H E$ A PT) $(n, P)(n, N)(n, G)$ \\
\hline $56 \mathrm{Ba} 131$ & $(\mathrm{n}, \mathrm{X} \backslash \mathrm{P})(\mathrm{n}, \mathrm{X} \backslash \mathrm{A})(\mathrm{n}, \mathrm{N} 3 \mathrm{HE}$ A PT) $(\mathrm{n}, \mathrm{P})(\mathrm{n}, \mathrm{G})$ \\
\hline $56 \mathrm{Ba} 133 \mathrm{~m} 1$ & $(\mathrm{n}, \mathrm{X} \backslash \mathrm{P})(\mathrm{n}, \mathrm{X} \backslash \mathrm{A})(\mathrm{n}, \mathrm{A}$ PT) $(\mathrm{n}, 3 \mathrm{HE} \mathrm{PD})(\mathrm{n}, \mathrm{P})(\mathrm{n}, \mathrm{N})(\mathrm{n}, \mathrm{G})$ \\
\hline $56 \mathrm{Ba} 135 \mathrm{~m} 1$ & $(n, X \backslash P)(n, X \backslash A)(n, A)(n, P)(n, N)(n, G)(n, G)$ \\
\hline 56Ba139 & $(\mathrm{n}, \mathrm{X} \backslash \mathrm{A})(\mathrm{n}, \mathrm{A})(\mathrm{n}, \mathrm{G})$ \\
\hline 57La135 & $(n, X \backslash P)(n, X \backslash A)(n, P A)(n, A)(n, P)(n, P)(n, G)(n, G)$ \\
\hline $57 \mathrm{La} 137$ & $(\mathrm{n}, \mathrm{X} \backslash \mathrm{P})(\mathrm{n}, \mathrm{X} \backslash \mathrm{A})(\mathrm{n}, \mathrm{A})(\mathrm{n}, \mathrm{A})(\mathrm{n}, \mathrm{P})(\mathrm{n}, \mathrm{G})$ \\
\hline $57 \mathrm{La} 141$ & $(\mathrm{n}, \mathrm{X} \backslash \mathrm{A})(\mathrm{n}, \mathrm{A})(\mathrm{n}, \mathrm{A})(\mathrm{n}, \mathrm{G})$ \\
\hline $58 \mathrm{Ce} 134$ & $(n, X \backslash P)(n, X \backslash A)(n, A$ PT) $(n, A$ PT) $(n, P)(n, G)(n, G)$ \\
\hline $58 \mathrm{Ce} 135$ & $(\mathrm{n}, \mathrm{X} \backslash \mathrm{P})(\mathrm{n}, \mathrm{X} \backslash \mathrm{A})(\mathrm{n}, \mathrm{N} 3 \mathrm{HE}$ A PT) $(\mathrm{n}, \mathrm{P})(\mathrm{n}, \mathrm{G})$ \\
\hline $58 \mathrm{Ce} 137$ & $(\mathrm{n}, \mathrm{X} \backslash \mathrm{P})(\mathrm{n}, \mathrm{X} \backslash \mathrm{A})(\mathrm{n}, \mathrm{N} 3 \mathrm{HE}$ A PT $)(\mathrm{n}, \mathrm{P})(\mathrm{n}, \mathrm{G})$ \\
\hline $58 \mathrm{Ce} 137 \mathrm{~m} 1$ & $(\mathrm{n}, \mathrm{X} \backslash \mathrm{P})(\mathrm{n}, \mathrm{X} \backslash \mathrm{A})(\mathrm{n}, \mathrm{N} 3 \mathrm{HE} \mathrm{A} \mathrm{PT})(\mathrm{n}, \mathrm{P})(\mathrm{n}, \mathrm{N})(\mathrm{n}, \mathrm{G})$ \\
\hline $60 \mathrm{Nd} 140$ & $(\mathrm{n}, \mathrm{X} \backslash \mathrm{P})(\mathrm{n}, \mathrm{X} \backslash \mathrm{A})(\mathrm{n}, \mathrm{PA})(\mathrm{n}, \mathrm{PA})(\mathrm{n}, \mathrm{A})(\mathrm{n}, \mathrm{A})(\mathrm{n}, \mathrm{P})(\mathrm{n}, \mathrm{G})(\mathrm{n}, \mathrm{G})$ \\
\hline $60 \mathrm{Nd} 141$ & $(\mathrm{n}, \mathrm{X} \backslash \mathrm{P})(\mathrm{n}, \mathrm{X} \backslash \mathrm{A})(\mathrm{n}, \mathrm{N} 3 \mathrm{HE}$ A PT) $(\mathrm{n}, \mathrm{P})(\mathrm{n}, \mathrm{G})$ \\
\hline $60 \mathrm{Nd} 149$ & $(\mathrm{n}, \mathrm{X} \backslash \mathrm{A})(\mathrm{n}, \mathrm{A})(\mathrm{n}, \mathrm{G})$ \\
\hline $61 \mathrm{Pm} 143$ & $(\mathrm{n}, \mathrm{X} \backslash \mathrm{P})(\mathrm{n}, \mathrm{X} \backslash \mathrm{A})(\mathrm{n}, \mathrm{A})(\mathrm{n}, \mathrm{P})(\mathrm{n}, \mathrm{G})$ \\
\hline $61 \mathrm{Pm} 144$ & $(\mathrm{n}, \mathrm{X} \backslash \mathrm{P})(\mathrm{n}, \mathrm{X} \backslash \mathrm{A})(\mathrm{n}, \mathrm{N} 3 \mathrm{HE}$ A PT) $(\mathrm{n}, \mathrm{P})(\mathrm{n}, \mathrm{G})$ \\
\hline
\end{tabular}




\begin{tabular}{|c|c|}
\hline Target Nucl. & Reactions \\
\hline $61 \mathrm{Pm} 145$ & $(n, X \backslash P)(n, X \backslash A)(n, A)(n, A)(n, P)(n, G)$ \\
\hline $61 \mathrm{Pm} 146$ & $(\mathrm{n}, \mathrm{X} \backslash \mathrm{P})(\mathrm{n}, \mathrm{X} \backslash \mathrm{A})(\mathrm{n}, 2 \mathrm{~A})(\mathrm{n}, \mathrm{N} 3 \mathrm{HE} \mathrm{A})(\mathrm{n}, \mathrm{P})(\mathrm{n}, \mathrm{G})$ \\
\hline $61 \mathrm{Pm} 150$ & $(\mathrm{n}, \mathrm{X} \backslash \mathrm{A})(\mathrm{n}, \mathrm{A})(\mathrm{n}, \mathrm{G})$ \\
\hline $62 \mathrm{Sm} 145$ & $(\mathrm{n}, \mathrm{X} \backslash \mathrm{P})(\mathrm{n}, \mathrm{X} \backslash \mathrm{A})(\mathrm{n}, \mathrm{N} 3 \mathrm{HE} \mathrm{A} \mathrm{PT})(\mathrm{n}, \mathrm{P})(\mathrm{n}, \mathrm{G})$ \\
\hline $62 \mathrm{Sm} 146$ & $(\mathrm{n}, \mathrm{X} \backslash \mathrm{A})(\mathrm{n}, \mathrm{A})(\mathrm{n}, \mathrm{G})$ \\
\hline $62 \mathrm{Sm} 156$ & $(\mathrm{n}, \mathrm{G})$ \\
\hline $63 \mathrm{Eu} 145$ & $(\mathrm{n}, \mathrm{X} \backslash \mathrm{P})(\mathrm{n}, \mathrm{X} \backslash \mathrm{A})(\mathrm{n}, \mathrm{A} \mathrm{PT})(\mathrm{n}, \mathrm{P})(\mathrm{n}, \mathrm{G})$ \\
\hline 63Eu146 & $(n, X \backslash P)(n, X \backslash A)(n, N P A D A)(n, P A)(n, N 3 H E A$ PT) $(n, P)(n, G)$ \\
\hline $63 \mathrm{Eu} 147$ & $(\mathrm{n}, \mathrm{X} \backslash \mathrm{P})(\mathrm{n}, \mathrm{X} \backslash \mathrm{A})(\mathrm{n}, \mathrm{N} 3 \mathrm{HE}$ A PT) $(\mathrm{n}, \mathrm{P})(\mathrm{n}, \mathrm{G})$ \\
\hline $63 \mathrm{Eu} 148$ & $(n, X \backslash P)(n, X \backslash A)(n, 2 A)(n, N 3 H E$ A PT) $(n, P)(n, G)$ \\
\hline $63 \mathrm{Eu} 149$ & $(\mathrm{n}, \mathrm{X} \backslash \mathrm{P})(\mathrm{n}, \mathrm{X} \backslash \mathrm{A})(\mathrm{n}, \mathrm{A})(\mathrm{n}, \mathrm{P})(\mathrm{n}, \mathrm{G})(\mathrm{n}, \mathrm{G})$ \\
\hline $63 \mathrm{Eu} 150$ & $(n, X \backslash P)(n, X \backslash A)(n, N 3 H E A)(n, P)(n, N)(n, G)$ \\
\hline $63 \mathrm{Eu} 150 \mathrm{~m} 1$ & $(n, X \backslash P)(n, X \backslash A)(n, N 3 H E$ A PT) $(n, P)(n, N)(n, G)$ \\
\hline 63Eu152m1 & $(n, X \backslash P)(n, X \backslash A)(n, A)(n, P)(n, N)(n, N)(n, G)$ \\
\hline $64 \mathrm{Gd} 146$ & $(n, X \backslash P)(n, X \backslash A)(n, A P T)(n, P)(n, G)$ \\
\hline $64 \mathrm{Gd} 147$ & $(n, X \backslash P)(n, X \backslash A)(n, 2 A)(n, N 3 H E A$ PT) $(n, P)(n, G)$ \\
\hline $64 \mathrm{Gd} 148$ & $(\mathrm{n}, \mathrm{X} \backslash \mathrm{A})(\mathrm{n}, \mathrm{N} 3 \mathrm{HE} \mathrm{A}$ PT) $(\mathrm{n}, \mathrm{G})$ \\
\hline $64 \mathrm{Gd} 149$ & $(n, X \backslash P)(n, X \backslash A)(n, 2 A)(n, N 3 H E A$ PT) $(n, P)(n, G)$ \\
\hline $64 \mathrm{Gd} 150$ & $(\mathrm{n}, \mathrm{X} \backslash \mathrm{A})(\mathrm{n}, \mathrm{N} 3 \mathrm{HE}$ A PT) $(\mathrm{n}, \mathrm{G})$ \\
\hline $64 \mathrm{Gd} 151$ & $(\mathrm{n}, \mathrm{X} \backslash \mathrm{P})(\mathrm{n}, \mathrm{X} \backslash \mathrm{A})(\mathrm{n}, 2 \mathrm{~A})(\mathrm{n}, \mathrm{N} 3 \mathrm{HE} \mathrm{A} \mathrm{PT})(\mathrm{n}, \mathrm{P})(\mathrm{n}, \mathrm{G})$ \\
\hline $64 \mathrm{Gd} 159$ & $(\mathrm{n}, \mathrm{X} \backslash \mathrm{A})(\mathrm{n}, \mathrm{A})(\mathrm{n}, \mathrm{G})$ \\
\hline $65 \mathrm{~Tb} 151$ & $(\mathrm{n}, \mathrm{X} \backslash \mathrm{P})(\mathrm{n}, \mathrm{X} \backslash \mathrm{A})(\mathrm{n}, 2 \mathrm{~A})(\mathrm{n}, \mathrm{N} 3 \mathrm{HE}$ A PT) $(\mathrm{n}, \mathrm{P})(\mathrm{n}, \mathrm{N})(\mathrm{n}, \mathrm{G})(\mathrm{n}, \mathrm{G})$ \\
\hline $65 \mathrm{~Tb} 152$ & $(n, X \backslash P)(n, X \backslash A)(n, 2 A)(n, N 3 H E A$ PT) $(n, P)(n, G)$ \\
\hline $65 \mathrm{~Tb} 153$ & $(n, X \backslash P)(n, X \backslash A)(n, A)(n, A)(n, P)(n, G)(n, G)(n, G)$ \\
\hline $65 \mathrm{~Tb} 154$ & $(n, X \backslash P)(n, X \backslash A)(n, T A)(n, N P A D A)(n, N 3 H E A$ PT) $(n, P)(n, G)$ \\
\hline $65 \mathrm{~Tb} 154 \mathrm{~m} 1$ & $(\mathrm{n}, \mathrm{X} \backslash \mathrm{P})(\mathrm{n}, \mathrm{X} \backslash \mathrm{A})(\mathrm{n}, 2 \mathrm{~A})(\mathrm{n}, \mathrm{N} 3 \mathrm{HE}$ A PT) $(\mathrm{n}, 3 \mathrm{HE} \mathrm{PD})(\mathrm{n}, \mathrm{P})(\mathrm{n}, \mathrm{G})$ \\
\hline $65 \mathrm{~Tb} 154 \mathrm{~m} 2$ & $(n, X \backslash P)(n, X \backslash A)(n, 2 A)(n, N 3 H E$ A PT) $(n, 3 H E$ PD) $(n, P)(n, N)(n, N)(n, G)$ \\
\hline $65 \mathrm{~Tb} 155$ & $(n, X \backslash P)(n, X \backslash A)(n, A)(n, A)(n, A)(n, P)(n, G)(n, G)(n, G)$ \\
\hline $65 \mathrm{~Tb} 156$ & $(n, X \backslash P)(n, X \backslash A)(n, A)(n, P)(n, N)(n, N)(n, G)$ \\
\hline $65 \mathrm{~Tb} 156 \mathrm{~m} 1$ & $(n, X \backslash P)(n, X \backslash A)(n, A)(n, P)(n, N)(n, N)(n, G)$ \\
\hline $65 \mathrm{~Tb} 156 \mathrm{~m} 2$ & $(n, X \backslash P)(n, X \backslash A)(n, A)(n, P)(n, N)(n, N)(n, G)$ \\
\hline $65 \mathrm{~Tb} 157$ & $(\mathrm{n}, \mathrm{X} \backslash \mathrm{A})(\mathrm{n}, \mathrm{A})(\mathrm{n}, \mathrm{A})(\mathrm{n}, \mathrm{G})$ \\
\hline $65 \mathrm{~Tb} 158$ & $(n, X \backslash P)(n, X \backslash A)(n, A)(n, P)(n, N)(n, G)$ \\
\hline $65 \mathrm{~Tb} 161$ & $(\mathrm{n}, \mathrm{X} \backslash \mathrm{A})(\mathrm{n}, \mathrm{A})(\mathrm{n}, \mathrm{G})$ \\
\hline 66Dy153 & $(n, X \backslash P)(n, X \backslash A)(n, 2 N 2 A)(n, 2 A)(n, T A)(n, N 3 H E A$ PT $)(n, P)(n, G)$ \\
\hline $66 \mathrm{Dy} 155$ & $(n, X \backslash P)(n, X \backslash A)(n, 2 A)(n, N 3 H E A$ PT) $(n, P)(n, G)$ \\
\hline 66Dy157 & $(\mathrm{n}, \mathrm{X} \backslash \mathrm{P})(\mathrm{n}, \mathrm{X} \backslash \mathrm{A})(\mathrm{n}, \mathrm{N} 3 \mathrm{HE} \mathrm{A} \mathrm{PT})(\mathrm{n}, \mathrm{P})(\mathrm{n}, \mathrm{G})$ \\
\hline $66 \mathrm{Dy} 165$ & $(\mathrm{n}, \mathrm{X} \backslash \mathrm{A})(\mathrm{n}, \mathrm{A})(\mathrm{n}, \mathrm{N})(\mathrm{n}, \mathrm{G})$ \\
\hline
\end{tabular}




\begin{tabular}{|c|c|}
\hline Target Nucl. & Reactions \\
\hline $66 \mathrm{Dy} 166$ & $(\mathrm{n}, \mathrm{G})$ \\
\hline $67 \mathrm{Ho} 163$ & $(\mathrm{n}, \mathrm{X} \backslash \mathrm{A})(\mathrm{n}, 2 \mathrm{NA})(\mathrm{n}, \mathrm{A})(\mathrm{n}, \mathrm{G})(\mathrm{n}, \mathrm{G})$ \\
\hline $67 \mathrm{Ho} 164$ & $(\mathrm{n}, \mathrm{X} \backslash \mathrm{P})(\mathrm{n}, \mathrm{X} \backslash \mathrm{A})(\mathrm{n}, \mathrm{A})(\mathrm{n}, \mathrm{P})(\mathrm{n}, \mathrm{N})(\mathrm{n}, \mathrm{G})$ \\
\hline 67Ho164m1 & $(\mathrm{n}, \mathrm{X} \backslash \mathrm{P})(\mathrm{n}, \mathrm{X} \backslash \mathrm{A})(\mathrm{n}, \mathrm{A})(\mathrm{n}, \mathrm{P})(\mathrm{n}, \mathrm{N})(\mathrm{n}, \mathrm{G})$ \\
\hline 67 Ho166 & $(\mathrm{n}, \mathrm{X} \backslash \mathrm{A})(\mathrm{n}, \mathrm{A})(\mathrm{n}, \mathrm{N})(\mathrm{n}, \mathrm{G})$ \\
\hline 67Ho166m1 & $(\mathrm{n}, \mathrm{X} \backslash \mathrm{A})(\mathrm{n}, \mathrm{A})(\mathrm{n}, \mathrm{N})(\mathrm{n}, \mathrm{G})$ \\
\hline $68 \operatorname{Er} 160$ & $(\mathrm{n}, \mathrm{X} \backslash \mathrm{P})(\mathrm{n}, \mathrm{X} \backslash \mathrm{A})(\mathrm{n}, \mathrm{A})(\mathrm{n}, \mathrm{P})(\mathrm{n}, \mathrm{G})$ \\
\hline $68 \operatorname{Er} 161$ & $(n, X \backslash P)(n, X \backslash A)(n, N 3 H E$ A PT) $(n, P)(n, P)(n, G)$ \\
\hline $68 \operatorname{Er} 165$ & $(\mathrm{n}, \mathrm{X} \backslash \mathrm{A})(\mathrm{n}, \mathrm{A})(\mathrm{n}, \mathrm{G})$ \\
\hline $68 \operatorname{Er} 169$ & $(\mathrm{n}, \mathrm{X} \backslash \mathrm{A})(\mathrm{n}, \mathrm{A})(\mathrm{n}, \mathrm{G})$ \\
\hline $68 \operatorname{Er} 171$ & $(\mathrm{n}, \mathrm{X} \backslash \mathrm{A})(\mathrm{n}, \mathrm{A})(\mathrm{n}, \mathrm{G})$ \\
\hline $68 \operatorname{Er} 172$ & $(\mathrm{n}, 2 \mathrm{NA})(\mathrm{n}, \mathrm{G})$ \\
\hline $69 \mathrm{Tm} 165$ & $(\mathrm{n}, \mathrm{X} \backslash \mathrm{P})(\mathrm{n}, \mathrm{X} \backslash \mathrm{A})(\mathrm{n}, 2 \mathrm{NA})(\mathrm{n}, \mathrm{A})(\mathrm{n}, \mathrm{A})(\mathrm{n}, \mathrm{P})(\mathrm{n}, \mathrm{G})$ \\
\hline 69Tm166 & $(\mathrm{n}, \mathrm{X} \backslash \mathrm{P})(\mathrm{n}, \mathrm{X} \backslash \mathrm{A})(\mathrm{n}, \mathrm{N} 3 \mathrm{HE} \mathrm{A})(\mathrm{n}, \mathrm{A})(\mathrm{n}, \mathrm{P})(\mathrm{n}, \mathrm{G})$ \\
\hline $69 \mathrm{Tm} 167$ & $(\mathrm{n}, \mathrm{X} \backslash \mathrm{P})(\mathrm{n}, \mathrm{X} \backslash 3 \mathrm{HE})(\mathrm{n}, \mathrm{X} \backslash \mathrm{A})(\mathrm{n}, \mathrm{A})(\mathrm{n}, \mathrm{A})(\mathrm{n}, 3 \mathrm{HE})(\mathrm{n}, \mathrm{P})(\mathrm{n}, \mathrm{P})(\mathrm{n}, \mathrm{G})$ \\
\hline $69 \operatorname{Tm} 168$ & $(\mathrm{n}, \mathrm{X} \backslash \mathrm{P})(\mathrm{n}, \mathrm{X} \backslash 3 \mathrm{HE})(\mathrm{n}, \mathrm{X} \backslash \mathrm{A})(\mathrm{n}, \mathrm{A})(\mathrm{n}, 3 \mathrm{HE})(\mathrm{n}, \mathrm{P})(\mathrm{n}, \mathrm{G})$ \\
\hline $69 \mathrm{Tm} 170$ & $(\mathrm{n}, \mathrm{X} \backslash \mathrm{A})(\mathrm{n}, \mathrm{A})(\mathrm{n}, \mathrm{G})$ \\
\hline 69Tm171 & $(\mathrm{n}, \mathrm{X} \backslash \mathrm{A})(\mathrm{n}, \mathrm{A})(\mathrm{n}, \mathrm{A})(\mathrm{n}, \mathrm{G})$ \\
\hline 69Tm172 & $(\mathrm{n}, \mathrm{X} \backslash \mathrm{P})(\mathrm{n}, \mathrm{X} \backslash \mathrm{A})(\mathrm{n}, \mathrm{A})(\mathrm{n}, \mathrm{P})(\mathrm{n}, \mathrm{G})$ \\
\hline $69 \mathrm{Tm} 173$ & $(\mathrm{n}, \mathrm{X} \backslash \mathrm{A})(\mathrm{n}, 2 \mathrm{NA})(\mathrm{n}, \mathrm{A})(\mathrm{n}, \mathrm{A})(\mathrm{n}, \mathrm{G})$ \\
\hline $70 Y b 166$ & $(\mathrm{n}, \mathrm{X} \backslash \mathrm{A})(\mathrm{n}, \mathrm{A})(\mathrm{n}, \mathrm{G})$ \\
\hline $70 \mathrm{Yb} 169$ & $(n, X \backslash P)(n, X \backslash A)(n, N 3 H E$ A PT) $(n, 3 H E)(n, P)(n, N)(n, G)$ \\
\hline $70 \mathrm{Yb} 175$ & $(\mathrm{n}, \mathrm{X} \backslash \mathrm{A})(\mathrm{n}, \mathrm{A})(\mathrm{n}, \mathrm{G})(\mathrm{n}, \mathrm{G})$ \\
\hline $71 \mathrm{Lu} 169$ & $(n, X \backslash P)(n, X \backslash A)(n, A)(n, P)(n, P)(n, N)(n, G)(n, G)$ \\
\hline $71 \mathrm{Lu} 170$ & $(n, X \backslash P)(n, X \backslash A)(n, N 3 H E A$ PT) $(n, P)(n, N)(n, G)(n, G)$ \\
\hline $71 \mathrm{Lu} 171$ & $(\mathrm{n}, \mathrm{X} \backslash \mathrm{P})(\mathrm{n}, \mathrm{X} \backslash \mathrm{A})(\mathrm{n}, \mathrm{A})(\mathrm{n}, \mathrm{P})(\mathrm{n}, \mathrm{N})(\mathrm{n}, \mathrm{G})$ \\
\hline $71 \mathrm{Lu} 172$ & $(n, X \backslash P)(n, X \backslash A)(n, N 3 H E A)(n, P)(n, N)(n, G)$ \\
\hline $71 \mathrm{Lu} 173$ & $(n, X \backslash P)(n, X \backslash A)(n, A)(n, P)(n, G)(n, G)$ \\
\hline $71 \mathrm{Lu} 174$ & $(\mathrm{n}, \mathrm{X} \backslash \mathrm{P})(\mathrm{n}, \mathrm{X} \backslash \mathrm{A})(\mathrm{n}, \mathrm{A})(\mathrm{n}, \mathrm{P})(\mathrm{n}, \mathrm{G})$ \\
\hline $71 \mathrm{Lu} 174 \mathrm{~m} 1$ & $(n, X \backslash P)(n, X \backslash A)(n, A)(n, P)(n, N)(n, G)$ \\
\hline $71 \mathrm{Lu} 177$ & $(\mathrm{n}, \mathrm{X} \backslash \mathrm{A})(\mathrm{n}, \mathrm{A})(\mathrm{n}, \mathrm{G})(\mathrm{n}, \mathrm{G})$ \\
\hline $71 \mathrm{Lu} 177 \mathrm{~m} 1$ & $(\mathrm{n}, \mathrm{X} \backslash \mathrm{A})(\mathrm{n}, \mathrm{A})(\mathrm{n}, \mathrm{N})(\mathrm{n}, \mathrm{G})(\mathrm{n}, \mathrm{G})$ \\
\hline $72 \mathrm{Hf} 170$ & $(n, X \backslash P)(n, X \backslash A)(n, N 3 H E$ A PT) $(n, P)(n, P)(n, G)(n, G)$ \\
\hline $72 \mathrm{Hf} 171$ & $(\mathrm{n}, \mathrm{X} \backslash \mathrm{P})(\mathrm{n}, \mathrm{X} \backslash \mathrm{A})(\mathrm{n}, 2 \mathrm{~A})(\mathrm{n}, \mathrm{N} 3 \mathrm{HE} \mathrm{A}$ PT) $(\mathrm{n}, \mathrm{P})(\mathrm{n}, \mathrm{P})(\mathrm{n}, \mathrm{G})$ \\
\hline $72 \mathrm{Hf} 172$ & $(\mathrm{n}, \mathrm{X} \backslash \mathrm{A})(\mathrm{n}, \mathrm{A})(\mathrm{n}, \mathrm{A})(\mathrm{n}, \mathrm{G})$ \\
\hline $72 \mathrm{Hf} 173$ & $(\mathrm{n}, \mathrm{X} \backslash \mathrm{P})(\mathrm{n}, \mathrm{X} \backslash \mathrm{A})(\mathrm{n}, \mathrm{N} 3 \mathrm{HE}$ A PT) $(\mathrm{n}, \mathrm{P})(\mathrm{n}, \mathrm{G})$ \\
\hline $72 \mathrm{Hf} 175$ & $(n, X \backslash P)(n, X \backslash A)(n, N 3 H E A)(n, P)(n, G)$ \\
\hline $72 \mathrm{Hf} 178 \mathrm{~m} 2$ & $(\mathrm{n}, \mathrm{X} \backslash \mathrm{A})(\mathrm{n}, \mathrm{A})(\mathrm{n}, \mathrm{N})(\mathrm{n}, \mathrm{N})(\mathrm{n}, \mathrm{G})(\mathrm{n}, \mathrm{G})$ \\
\hline
\end{tabular}




\begin{tabular}{|c|c|}
\hline Target Nucl. & Reactions \\
\hline $72 \mathrm{Hf} 179 \mathrm{~m} 2$ & $(\mathrm{n}, \mathrm{X} \backslash \mathrm{A})(\mathrm{n}, \mathrm{A})(\mathrm{n}, \mathrm{A})(\mathrm{n}, \mathrm{N})(\mathrm{n}, \mathrm{N})(\mathrm{n}, \mathrm{G})(\mathrm{n}, \mathrm{G})$ \\
\hline $72 \mathrm{Hf} 180 \mathrm{~m} 1$ & $(\mathrm{n}, \mathrm{X} \backslash \mathrm{A})(\mathrm{n}, \mathrm{A})(\mathrm{n}, \mathrm{A})(\mathrm{n}, \mathrm{N})(\mathrm{n}, \mathrm{G})$ \\
\hline $73 \mathrm{Ta} 175$ & $(n, X \backslash P)(n, X \backslash A)(n, N P A D A)(n, A)(n, P)(n, G)$ \\
\hline 73Ta176 & $(n, X \backslash P)(n, X \backslash A)(n, N 2 A)(n, N 3 H E A$ PT) $(n, P)(n, G)$ \\
\hline $73 \mathrm{Ta} 177$ & $(\mathrm{n}, \mathrm{X} \backslash \mathrm{P})(\mathrm{n}, \mathrm{X} \backslash \mathrm{A})(\mathrm{n}, \mathrm{A})(\mathrm{n}, \mathrm{A})(\mathrm{n}, \mathrm{P})(\mathrm{n}, \mathrm{P})(\mathrm{n}, \mathrm{G})$ \\
\hline $73 \mathrm{Ta} 179$ & $(\mathrm{n}, \mathrm{X} \backslash \mathrm{A})(\mathrm{n}, \mathrm{A})(\mathrm{n}, \mathrm{A})(\mathrm{n}, \mathrm{G})(\mathrm{n}, \mathrm{G})$ \\
\hline $73 \mathrm{Ta} 180$ & $(\mathrm{n}, \mathrm{X} \backslash \mathrm{P})(\mathrm{n}, \mathrm{X} \backslash \mathrm{A})(\mathrm{n}, \mathrm{A})(\mathrm{n}, \mathrm{A})(\mathrm{n}, \mathrm{A})(\mathrm{n}, \mathrm{P})(\mathrm{n}, \mathrm{N})(\mathrm{n}, \mathrm{G})$ \\
\hline $73 \mathrm{Ta} 180 \mathrm{~m} 1$ & $(\mathrm{n}, \mathrm{X} \backslash \mathrm{A})(\mathrm{n}, \mathrm{A})(\mathrm{n}, \mathrm{A})(\mathrm{n}, \mathrm{A})(\mathrm{n}, \mathrm{N})(\mathrm{n}, \mathrm{G})$ \\
\hline $73 \mathrm{Ta} 183$ & $(\mathrm{n}, \mathrm{X} \backslash \mathrm{A})(\mathrm{n}, \mathrm{A})(\mathrm{n}, \mathrm{A})(\mathrm{n}, \mathrm{G})$ \\
\hline $73 \mathrm{Ta} 184$ & $(\mathrm{n}, \mathrm{X} \backslash \mathrm{A})(\mathrm{n}, \mathrm{A})(\mathrm{n}, \mathrm{G})$ \\
\hline $74 \mathrm{~W} 178$ & $(\mathrm{n}, \mathrm{X} \backslash \mathrm{A})(\mathrm{n}, \mathrm{A})(\mathrm{n}, \mathrm{G})(\mathrm{n}, \mathrm{G})$ \\
\hline $74 \mathrm{~W} 181$ & $(\mathrm{n}, \mathrm{X} \backslash \mathrm{A})(\mathrm{n}, \mathrm{A})(\mathrm{n}, \mathrm{A})(\mathrm{n}, \mathrm{A})(\mathrm{n}, \mathrm{G})$ \\
\hline $74 \mathrm{~W} 185$ & $(\mathrm{n}, \mathrm{X} \backslash \mathrm{A})(\mathrm{n}, \mathrm{A})(\mathrm{n}, \mathrm{A})(\mathrm{n}, \mathrm{G})$ \\
\hline $74 \mathrm{~W} 187$ & $(\mathrm{n}, \mathrm{X} \backslash \mathrm{A})(\mathrm{n}, \mathrm{A})(\mathrm{n}, \mathrm{A})(\mathrm{n}, \mathrm{G})$ \\
\hline 74W188 & $(\mathrm{n}, \mathrm{X} \backslash \mathrm{A})(\mathrm{n}, \mathrm{A})(\mathrm{n}, \mathrm{G})$ \\
\hline $75 \operatorname{Re} 181$ & $(\mathrm{n}, \mathrm{X} \backslash \mathrm{P})(\mathrm{n}, \mathrm{X} \backslash \mathrm{A})(\mathrm{n}, \mathrm{A})(\mathrm{n}, \mathrm{P})(\mathrm{n}, \mathrm{G})(\mathrm{n}, \mathrm{G})$ \\
\hline $75 \operatorname{Re} 182$ & $(n, X \backslash P)(n, X \backslash A)(n, N 3 H E A)(n, P)(n, N)(n, G)$ \\
\hline $75 \operatorname{Re} 182 \mathrm{~m} 1$ & $(n, X \backslash P)(n, X \backslash A)(n, N 3 H E A$ PT) $(n, P)(n, N)(n, G)$ \\
\hline $75 \operatorname{Re} 183$ & $(n, X \backslash A)(n, A)(n, A)(n, G)(n, G)$ \\
\hline $75 \operatorname{Re} 184$ & $(\mathrm{n}, \mathrm{X} \backslash \mathrm{P})(\mathrm{n}, \mathrm{X} \backslash \mathrm{A})(\mathrm{n}, \mathrm{A})(\mathrm{n}, \mathrm{P})(\mathrm{n}, \mathrm{G})$ \\
\hline $75 \operatorname{Re} 184 \mathrm{~m} 1$ & $(\mathrm{n}, \mathrm{X} \backslash \mathrm{P})(\mathrm{n}, \mathrm{X} \backslash \mathrm{A})(\mathrm{n}, \mathrm{A})(\mathrm{n}, \mathrm{P})(\mathrm{n}, \mathrm{N})(\mathrm{n}, \mathrm{G})$ \\
\hline $75 \operatorname{Re} 186$ & $(\mathrm{n}, \mathrm{X} \backslash \mathrm{A})(\mathrm{n}, \mathrm{A})(\mathrm{n}, \mathrm{G})$ \\
\hline $75 \operatorname{Re} 186 \mathrm{~m} 1$ & $(\mathrm{n}, \mathrm{X} \backslash \mathrm{A})(\mathrm{n}, \mathrm{A})(\mathrm{n}, \mathrm{N})(\mathrm{n}, \mathrm{G})$ \\
\hline $75 \operatorname{Re} 188$ & $(\mathrm{n}, \mathrm{X} \backslash \mathrm{A})(\mathrm{n}, \mathrm{A})(\mathrm{n}, \mathrm{G})$ \\
\hline $75 \operatorname{Re} 189$ & $(\mathrm{n}, \mathrm{X} \backslash \mathrm{A})(\mathrm{n}, \mathrm{A})(\mathrm{n}, \mathrm{G})(\mathrm{n}, \mathrm{G})$ \\
\hline $76 \mathrm{Os} 182$ & $(\mathrm{n}, \mathrm{X} \backslash \mathrm{A})(\mathrm{n}, \mathrm{A})(\mathrm{n}, \mathrm{A})(\mathrm{n}, \mathrm{G})(\mathrm{n}, \mathrm{G})$ \\
\hline $76 \mathrm{Os} 183$ & $(\mathrm{n}, \mathrm{X} \backslash \mathrm{P})(\mathrm{n}, \mathrm{X} \backslash \mathrm{A})(\mathrm{n}, \mathrm{N} 3 \mathrm{HE}$ A PT) $(\mathrm{n}, \mathrm{P})(\mathrm{n}, \mathrm{G})$ \\
\hline $76 \mathrm{Os} 183 \mathrm{~m} 1$ & $(\mathrm{n}, \mathrm{X} \backslash \mathrm{P})(\mathrm{n}, \mathrm{X} \backslash \mathrm{A})(\mathrm{n}, \mathrm{N} 3 \mathrm{HE}$ A PT) $(\mathrm{n}, \mathrm{P})(\mathrm{n}, \mathrm{G})$ \\
\hline $76 \mathrm{Os} 185$ & $(n, X \backslash P)(n, X \backslash A)(n, N 3 H E A)(n, P)(n, G)$ \\
\hline 76 Os191 & $(n, X \backslash A)(n, A)(n, N)(n, G)(n, G)$ \\
\hline $76 \mathrm{Os} 191 \mathrm{~m} 1$ & $(\mathrm{n}, \mathrm{X} \backslash \mathrm{A})(\mathrm{n}, \mathrm{A})(\mathrm{n}, \mathrm{N})(\mathrm{n}, \mathrm{G})(\mathrm{n}, \mathrm{G})$ \\
\hline $760 s 193$ & $(\mathrm{n}, \mathrm{X} \backslash \mathrm{A})(\mathrm{n}, \mathrm{A})(\mathrm{n}, \mathrm{G})$ \\
\hline $76 \mathrm{Os} 194$ & $(\mathrm{n}, \mathrm{G})$ \\
\hline 77Ir185 & $(n, X \backslash P)(n, X \backslash A)(n, A)(n, A)(n, P)(n, G)(n, G)$ \\
\hline 77Ir186 & $(n, X \backslash P)(n, X \backslash A)(n, N 3 H E A$ PT) $(n, P)(n, N)(n, G)$ \\
\hline 77Ir 187 & $(\mathrm{n}, \mathrm{X} \backslash \mathrm{P})(\mathrm{n}, \mathrm{X} \backslash \mathrm{A})(\mathrm{n}, \mathrm{A})(\mathrm{n}, \mathrm{A})(\mathrm{n}, 2 \mathrm{P})(\mathrm{n}, \mathrm{P})(\mathrm{n}, \mathrm{G})$ \\
\hline 77Ir 188 & $(n, X \backslash P)(n, X \backslash A)(n, N 3 H E A)(n, P)(n, G)$ \\
\hline 77Ir189 & $(\mathrm{n}, \mathrm{X} \backslash \mathrm{A})(\mathrm{n}, \mathrm{A})(\mathrm{n}, \mathrm{A})(\mathrm{n}, \mathrm{G})$ \\
\hline
\end{tabular}




\begin{tabular}{|c|c|}
\hline Target Nucl. & Reactions \\
\hline 77Ir190 & $(n, X \backslash P)(n, X \backslash A)(n, A)(n, P)(n, P)(n, N)(n, N)(n, G)(n, G)$ \\
\hline 77Ir192 & $(n, X \backslash P)(n, X \backslash A)(n, A)(n, P)(n, N)(n, G)(n, G)$ \\
\hline 77Ir192m2 & $(\mathrm{n}, \mathrm{X} \backslash \mathrm{A})(\mathrm{n}, \mathrm{A})(\mathrm{n}, \mathrm{P})(\mathrm{n}, \mathrm{N})(\mathrm{n}, \mathrm{N})(\mathrm{n}, \mathrm{G})(\mathrm{n}, \mathrm{G})$ \\
\hline 77Ir193m1 & $(n, X \backslash A)(n, A)(n, A)(n, N)(n, G)(n, G)(n, G)$ \\
\hline 77Ir194 & $(\mathrm{n}, \mathrm{X} \backslash \mathrm{A})(\mathrm{n}, \mathrm{A})(\mathrm{n}, \mathrm{G})(\mathrm{n}, \mathrm{G})$ \\
\hline 77Ir194m2 & $(\mathrm{n}, \mathrm{X} \backslash \mathrm{P})(\mathrm{n}, \mathrm{X} \backslash \mathrm{A})(\mathrm{n}, \mathrm{NA})(\mathrm{n}, \mathrm{NA})(\mathrm{n}, \mathrm{A})(\mathrm{n}, \mathrm{P})(\mathrm{n}, \mathrm{N})(\mathrm{n}, \mathrm{N})(\mathrm{n}, \mathrm{G})(\mathrm{n}, \mathrm{G})$ \\
\hline 77) Ir196m 1 & $(\mathrm{n}, \mathrm{X} \backslash \mathrm{A})(\mathrm{n}, \mathrm{A})(\mathrm{n}, \mathrm{N})(\mathrm{n}, \mathrm{G})(\mathrm{n}, \mathrm{G})$ \\
\hline $78 \mathrm{Pt} 188$ & $(\mathrm{n}, \mathrm{X} \backslash \mathrm{A})(\mathrm{n}, \mathrm{A})(\mathrm{n}, \mathrm{G})$ \\
\hline $78 \mathrm{Pt} 189$ & $(\mathrm{n}, \mathrm{X} \backslash \mathrm{P})(\mathrm{n}, \mathrm{X} \backslash \mathrm{A})(\mathrm{n}, 2 \mathrm{~A})(\mathrm{n}, \mathrm{N} 3 \mathrm{HE}$ A PT) $(\mathrm{n}, \mathrm{P})(\mathrm{n}, \mathrm{G})$ \\
\hline 78Pt190 & $(\mathrm{n}, \mathrm{X} \backslash \mathrm{A})(\mathrm{n}, \mathrm{A})(\mathrm{n}, \mathrm{G})$ \\
\hline 78Pt191 & $(n, X \backslash P)(n, X \backslash A)(n, N 3 H E A)(n, P)(n, G)$ \\
\hline 78 Pt192 & $(\mathrm{n}, \mathrm{X} \backslash \mathrm{A})(\mathrm{n}, \mathrm{A})(\mathrm{n}, \mathrm{A})(\mathrm{n}, \mathrm{G})(\mathrm{n}, \mathrm{G})$ \\
\hline $78 \mathrm{Pt} 193$ & $(\mathrm{n}, \mathrm{X} \backslash \mathrm{A})(\mathrm{n}, \mathrm{A})(\mathrm{n}, \mathrm{A})(\mathrm{n}, \mathrm{G})$ \\
\hline 78Pt193m1 & $(\mathrm{n}, \mathrm{X} \backslash \mathrm{A})(\mathrm{n}, \mathrm{A})(\mathrm{n}, \mathrm{A})(\mathrm{n}, \mathrm{N})(\mathrm{n}, \mathrm{G})$ \\
\hline $78 \mathrm{Pt} 194$ & $(\mathrm{n}, \mathrm{X} \backslash \mathrm{A})(\mathrm{n}, \mathrm{A})(\mathrm{n}, \mathrm{A})(\mathrm{n}, \mathrm{G})(\mathrm{n}, \mathrm{G})$ \\
\hline $78 \mathrm{Pt} 195$ & $(\mathrm{n}, \mathrm{X} \backslash \mathrm{A})(\mathrm{n}, \mathrm{A})(\mathrm{n}, \mathrm{A})(\mathrm{n}, \mathrm{G})$ \\
\hline 78Pt195m1 & $(\mathrm{n}, \mathrm{X} \backslash \mathrm{A})(\mathrm{n}, \mathrm{A})(\mathrm{n}, \mathrm{A})(\mathrm{n}, \mathrm{P})(\mathrm{n}, \mathrm{N})(\mathrm{n}, \mathrm{G})$ \\
\hline 78Pt196 & $(\mathrm{n}, \mathrm{X} \backslash \mathrm{A})(\mathrm{n}, \mathrm{A})(\mathrm{n}, \mathrm{G})(\mathrm{n}, \mathrm{G})$ \\
\hline 78Pt197 & $(\mathrm{n}, \mathrm{X} \backslash \mathrm{A})(\mathrm{n}, \mathrm{A})(\mathrm{n}, \mathrm{G})$ \\
\hline 78Pt198 & $(\mathrm{n}, \mathrm{G})(\mathrm{n}, \mathrm{G})$ \\
\hline $78 \mathrm{Pt} 200$ & $(\mathrm{n}, \mathrm{G})$ \\
\hline $78 \mathrm{Pt} 202$ & $(n, G)$ \\
\hline 79Au193 & $(n, X \backslash P)(n, X \backslash A)(n, A)(n, P)(n, G)(n, G)(n, G)$ \\
\hline 79Au194 & $(\mathrm{n}, \mathrm{X} \backslash \mathrm{P})(\mathrm{n}, \mathrm{X} \backslash \mathrm{A})(\mathrm{n}, \mathrm{A})(\mathrm{n}, \mathrm{A})(\mathrm{n}, \mathrm{A})(\mathrm{n}, \mathrm{P})(\mathrm{n}, \mathrm{N})(\mathrm{n}, \mathrm{G})(\mathrm{n}, \mathrm{G})$ \\
\hline 79Au195 & $(\mathrm{n}, \mathrm{X} \backslash \mathrm{A})(\mathrm{n}, 2 \mathrm{NA})(\mathrm{n}, \mathrm{A})(\mathrm{n}, \mathrm{A})(\mathrm{n}, \mathrm{A})(\mathrm{n}, 2 \mathrm{P})(\mathrm{n}, \mathrm{G})(\mathrm{n}, \mathrm{G})$ \\
\hline 79Au196 & $(\mathrm{n}, \mathrm{X} \backslash \mathrm{P})(\mathrm{n}, \mathrm{X} \backslash \mathrm{A})(\mathrm{n}, 2 \mathrm{NA})(\mathrm{n}, \mathrm{A})(\mathrm{n}, \mathrm{A})(\mathrm{n}, \mathrm{P})(\mathrm{n}, \mathrm{N})(\mathrm{n}, \mathrm{N})(\mathrm{n}, \mathrm{G})(\mathrm{n}, \mathrm{G})$ \\
\hline 79Au196m2 & $(\mathrm{n}, \mathrm{X} \backslash \mathrm{A})(\mathrm{n}, \mathrm{A})(\mathrm{n}, \mathrm{A})(\mathrm{n}, \mathrm{G})(\mathrm{n}, \mathrm{G})$ \\
\hline 79Au198 & $(\mathrm{n}, \mathrm{X} \backslash \mathrm{A})(\mathrm{n}, \mathrm{A})(\mathrm{n}, \mathrm{A})(\mathrm{n}, \mathrm{G})$ \\
\hline 79Au198m1 & $(\mathrm{n}, \mathrm{X} \backslash \mathrm{A})(\mathrm{n}, \mathrm{A})(\mathrm{n}, \mathrm{A})(\mathrm{n}, \mathrm{N})(\mathrm{n}, \mathrm{G})$ \\
\hline 79Au199 & $(\mathrm{n}, \mathrm{G})(\mathrm{n}, \mathrm{G})$ \\
\hline 79Au200m1 & $(\mathrm{n}, \mathrm{X} \backslash \mathrm{A})(\mathrm{n}, \mathrm{A})(\mathrm{n}, \mathrm{A})(\mathrm{n}, \mathrm{N})(\mathrm{n}, \mathrm{G})$ \\
\hline $80 \mathrm{Hg} 193$ & $(n, X \backslash P)(n, X \backslash A)(n, N 3 H E A$ PT $)(n, P)(n, P)(n, N)(n, G)$ \\
\hline $80 \mathrm{Hg} 193 \mathrm{~m} 1$ & $(n, X \backslash P)(n, X \backslash A)(n, N 3 H E$ A PT) $(n, P)(n, P)(n, N)(n, G)$ \\
\hline $80 \mathrm{Hg} 194$ & $(\mathrm{n}, \mathrm{X} \backslash \mathrm{A})(\mathrm{n}, \mathrm{A})(\mathrm{n}, \mathrm{G})(\mathrm{n}, \mathrm{G})$ \\
\hline $80 \mathrm{Hg} 195$ & $(n, X \backslash P)(n, X \backslash 3 H E)(n, X \backslash A)(n, A)(n, 3 H E)(n, P)(n, P)(n, G)$ \\
\hline $80 \mathrm{Hg} 195 \mathrm{~m} 1$ & $(n, X \backslash P)(n, X \backslash A)(n, A)(n, P)(n, P)(n, N)(n, G)$ \\
\hline $80 \mathrm{Hg} 197$ & $(\mathrm{n}, \mathrm{X} \backslash \mathrm{A})(\mathrm{n}, \mathrm{A})(\mathrm{n}, \mathrm{G})$ \\
\hline $80 \mathrm{Hg} 197 \mathrm{~m} 1$ & $(\mathrm{n}, \mathrm{X} \backslash \mathrm{A})(\mathrm{n}, \mathrm{A})(\mathrm{n}, \mathrm{N})(\mathrm{n}, \mathrm{G})$ \\
\hline
\end{tabular}




\begin{tabular}{|c|c|}
\hline Target Nucl. & Reactions \\
\hline $80 \mathrm{Hg} 203$ & $(\mathrm{n}, \mathrm{X} \backslash \mathrm{A})(\mathrm{n}, \mathrm{A})(\mathrm{n}, \mathrm{G})$ \\
\hline $81 \mathrm{~T} 1199$ & $(\mathrm{n}, \mathrm{X} \backslash \mathrm{P})(\mathrm{n}, \mathrm{X} \backslash \mathrm{A})(\mathrm{n}, 2 \mathrm{NA})(\mathrm{n}, \mathrm{A})(\mathrm{n}, \mathrm{A})(\mathrm{n}, \mathrm{A})(\mathrm{n}, \mathrm{P})(\mathrm{n}, \mathrm{G})$ \\
\hline $81 \mathrm{~T} 1200$ & $(\mathrm{n}, \mathrm{X} \backslash \mathrm{P})(\mathrm{n}, \mathrm{X} \backslash \mathrm{A})(\mathrm{n}, \mathrm{A})(\mathrm{n}, \mathrm{A})(\mathrm{n}, \mathrm{P})(\mathrm{n}, \mathrm{G})$ \\
\hline $81 \mathrm{~T} 1201$ & $(\mathrm{n}, \mathrm{X} \backslash \mathrm{A})(\mathrm{n}, \mathrm{A})(\mathrm{n}, \mathrm{A})(\mathrm{n}, \mathrm{G})$ \\
\hline $81 \mathrm{~T} 1202$ & $(\mathrm{n}, \mathrm{X} \backslash \mathrm{P})(\mathrm{n}, \mathrm{X} \backslash \mathrm{A})(\mathrm{n}, \mathrm{A})(\mathrm{n}, \mathrm{P})(\mathrm{n}, \mathrm{G})$ \\
\hline $81 \mathrm{~T} 1203$ & $(\mathrm{n}, \mathrm{X} \backslash \mathrm{A})(\mathrm{n}, \mathrm{A})(\mathrm{n}, \mathrm{A})(\mathrm{n}, \mathrm{G})$ \\
\hline $81 \mathrm{~T} 1204$ & $(\mathrm{n}, \mathrm{X} \backslash \mathrm{A})(\mathrm{n}, \mathrm{A})(\mathrm{n}, \mathrm{G})$ \\
\hline $81 \mathrm{~T} 1205$ & $(\mathrm{n}, \mathrm{G})(\mathrm{n}, \mathrm{G})$ \\
\hline $82 \mathrm{~Pb} 200$ & $(n, X \backslash P)(n, X \backslash A)(n, A)(n, A)(n, P)(n, G)(n, G)$ \\
\hline $82 \mathrm{~Pb} 201$ & $(n, X \backslash P)(n, X \backslash A)(n, A)(n, 3 H E)(n, P)(n, G)(n, G)$ \\
\hline $82 \mathrm{~Pb} 202$ & $(\mathrm{n}, \mathrm{X} \backslash 3 \mathrm{HE})(\mathrm{n}, \mathrm{X} \backslash \mathrm{A})(\mathrm{n}, 2 \mathrm{NA})(\mathrm{n}, \mathrm{A})(\mathrm{n}, \mathrm{A})(\mathrm{n}, 3 \mathrm{HE})(\mathrm{n}, \mathrm{G})$ \\
\hline $82 \mathrm{~Pb} 203$ & $(n, X \backslash P)(n, X \backslash A)(n, A)(n, P)(n, G)(n, G)$ \\
\hline $82 \mathrm{~Pb} 205$ & $(\mathrm{n}, \mathrm{X} \backslash \mathrm{A})(\mathrm{n}, \mathrm{A})(\mathrm{n}, \mathrm{G})$ \\
\hline $82 \mathrm{~Pb} 209$ & $(\mathrm{n}, \mathrm{X} \backslash \mathrm{A})(\mathrm{n}, \mathrm{A})(\mathrm{n}, \mathrm{G})$ \\
\hline $82 \mathrm{~Pb} 210$ & $(\mathrm{n}, \mathrm{X} \backslash \mathrm{A})(\mathrm{n}, \mathrm{A})(\mathrm{n}, \mathrm{G})$ \\
\hline $82 \mathrm{~Pb} 212$ & $(\mathrm{n}, \mathrm{X} \backslash \mathrm{A})(\mathrm{n}, \mathrm{A})(\mathrm{n}, \mathrm{G})$ \\
\hline 83Bi203 & $(\mathrm{n}, \mathrm{X} \backslash \mathrm{P})(\mathrm{n}, \mathrm{X} \backslash \mathrm{A})(\mathrm{n}, \mathrm{A})(\mathrm{n}, \mathrm{P})(\mathrm{n}, \mathrm{P})(\mathrm{n}, \mathrm{P})(\mathrm{n}, \mathrm{G})$ \\
\hline 83Bi204 & $(\mathrm{n}, \mathrm{X} \backslash \mathrm{P})(\mathrm{n}, \mathrm{X} \backslash \mathrm{A})(\mathrm{n}, \mathrm{A})(\mathrm{n}, \mathrm{P})(\mathrm{n}, \mathrm{P})(\mathrm{n}, \mathrm{G})$ \\
\hline 83Bi205 & $(\mathrm{n}, \mathrm{X} \backslash \mathrm{P})(\mathrm{n}, \mathrm{X} \backslash \mathrm{A})(\mathrm{n}, \mathrm{A})(\mathrm{n}, \mathrm{P})(\mathrm{n}, \mathrm{P})(\mathrm{n}, \mathrm{G})$ \\
\hline 83Bi206 & $(\mathrm{n}, \mathrm{X} \backslash \mathrm{P})(\mathrm{n}, \mathrm{X} \backslash \mathrm{A})(\mathrm{n}, \mathrm{A})(\mathrm{n}, \mathrm{P})(\mathrm{n}, \mathrm{G})$ \\
\hline 83Bi207 & $(\mathrm{n}, \mathrm{X} \backslash \mathrm{P})(\mathrm{n}, \mathrm{X} \backslash \mathrm{A})(\mathrm{n}, \mathrm{A})(\mathrm{n}, \mathrm{P})(\mathrm{n}, \mathrm{G})(\mathrm{n}, \mathrm{G})$ \\
\hline 83Bi208 & $(\mathrm{n}, \mathrm{X} \backslash \mathrm{P})(\mathrm{n}, \mathrm{X} \backslash \mathrm{A})(\mathrm{n}, \mathrm{A})(\mathrm{n}, \mathrm{P})(\mathrm{n}, \mathrm{G})$ \\
\hline $83 \mathrm{Bi} 210$ & $(\mathrm{n}, \mathrm{X} \backslash \mathrm{A})(\mathrm{n}, \mathrm{N} 3 \mathrm{HE} \mathrm{A})(\mathrm{n}, \mathrm{A})(\mathrm{n}, \mathrm{G})$ \\
\hline $83 \mathrm{Bi} 210 \mathrm{~m} 1$ & $(\mathrm{n}, \mathrm{X} \backslash \mathrm{A})(\mathrm{n}, \mathrm{N} 3 \mathrm{HE} \mathrm{A})(\mathrm{n}, \mathrm{A})(\mathrm{n}, \mathrm{N})(\mathrm{n}, \mathrm{G})$ \\
\hline $84 \mathrm{Po} 206$ & $(n, X \backslash P)(n, X \backslash A)(n, A)(n, A)(n, A)(n, P)(n, G)(n, G)$ \\
\hline $84 \mathrm{Po} 207$ & $(n, X \backslash P)(n, X \backslash A)(n, N 3 H E$ A PT) $(n, N 3 H E$ A PT $)(n, P)(n, G)$ \\
\hline $84 \mathrm{Po} 208$ & $(n, X \backslash P)(n, X \backslash A)(n, N 3 H E$ A PT) $(n, N 3 H E$ A PT $)(n, P)(n, P)(n, G)$ \\
\hline $84 \mathrm{Po} 209$ & $(\mathrm{n}, \mathrm{X} \backslash \mathrm{P})(\mathrm{n}, \mathrm{X} \backslash \mathrm{A})(\mathrm{n}, \mathrm{N} 3 \mathrm{HE}$ A PT) $(\mathrm{n}, \mathrm{P})(\mathrm{n}, \mathrm{G})$ \\
\hline $84 \mathrm{Po} 210$ & $(n, X \backslash A)(n, N 3 H E A)(n, A)(n, G)(n, G)$ \\
\hline $85 \mathrm{At} 210$ & $(\mathrm{n}, \mathrm{X} \backslash \mathrm{P})(\mathrm{n}, \mathrm{X} \backslash \mathrm{A})(\mathrm{n}, 2 \mathrm{~A})(\mathrm{n}, \mathrm{PA})(\mathrm{n}, \mathrm{NA})(\mathrm{n}, \mathrm{N} 3 \mathrm{HE} \mathrm{A} \mathrm{PT})(\mathrm{n}, \mathrm{P})(\mathrm{n}, \mathrm{G})$ \\
\hline $85 \mathrm{At} 211$ & $(\mathrm{n}, \mathrm{X} \backslash \mathrm{A})(\mathrm{n}, \mathrm{NA})(\mathrm{n}, \mathrm{N} 3 \mathrm{HE}$ A PT) $(\mathrm{n}, \mathrm{N} 3 \mathrm{HE}$ A PT) $(\mathrm{n}, 2 \mathrm{P})(\mathrm{n}, \mathrm{G})(\mathrm{n}, \mathrm{G})$ \\
\hline $86 \operatorname{Rn} 211$ & $(\mathrm{n}, \mathrm{X} \backslash \mathrm{P})(\mathrm{n}, \mathrm{X} \backslash \mathrm{A})(\mathrm{n}, 2 \mathrm{~A})(\mathrm{n}, 2 \mathrm{~A})(\mathrm{n}, \mathrm{NA})(\mathrm{n}, \mathrm{NA})(\mathrm{n}, \mathrm{N} 3 \mathrm{HE} \mathrm{A} \mathrm{PT})(\mathrm{n}, \mathrm{P})(\mathrm{n}, \mathrm{G})$ \\
\hline $86 \mathrm{Rn} 222$ & $(\mathrm{n}, \mathrm{X} \backslash \mathrm{A})(\mathrm{n}, 2 \mathrm{NA})(\mathrm{n}, \mathrm{A})(\mathrm{n}, \mathrm{G})$ \\
\hline $88 \mathrm{Ra} 228$ & $(\mathrm{n}, \mathrm{X} \backslash \mathrm{A})(\mathrm{n}, \mathrm{A})(\mathrm{n}, \mathrm{G})$ \\
\hline 89 Ac228 & $(\mathrm{n}, \mathrm{X} \backslash \mathrm{A})(\mathrm{n}, \mathrm{A})(\mathrm{n}, \mathrm{G})$ \\
\hline $91 \mathrm{~Pa} 228$ & $(\mathrm{n}, \mathrm{X} \backslash \mathrm{P})(\mathrm{n}, \mathrm{X} \backslash \mathrm{A})(\mathrm{n}, \mathrm{N} 3 \mathrm{~A})(\mathrm{n}, \mathrm{N} 2 \mathrm{~A})(\mathrm{n}, 2 \mathrm{~A})(\mathrm{n}, \mathrm{NA})(\mathrm{n}, \mathrm{N} 3 \mathrm{HE} \mathrm{A})(\mathrm{n}, \mathrm{P})(\mathrm{n}, \mathrm{G})$ \\
\hline $91 \mathrm{~Pa} 234$ & $(\mathrm{n}, \mathrm{X} \backslash \mathrm{A})(\mathrm{n}, \mathrm{A})(\mathrm{n}, \mathrm{G})$ \\
\hline $93 \mathrm{~Np} 236 \mathrm{~m} 1$ & $(\mathrm{n}, \mathrm{X} \backslash \mathrm{A})(\mathrm{n}, \mathrm{A})(\mathrm{n}, \mathrm{G})$ \\
\hline
\end{tabular}




\begin{tabular}{|l|l|}
\hline Target Nucl. & Reactions \\
\hline 94Pu234 & $(\mathrm{n}, \mathrm{X} \backslash \mathrm{A})(\mathrm{n}, 2 \mathrm{~A})(\mathrm{n}, \mathrm{NA})(\mathrm{n}, \mathrm{A})(\mathrm{n}, \mathrm{G})$ \\
\hline 94Pu245 & $(\mathrm{n}, \mathrm{X} \backslash \mathrm{A})(\mathrm{n}, 2 \mathrm{NA})(\mathrm{n}, \mathrm{A})(\mathrm{n}, \mathrm{G})$ \\
\hline 94Pu247 & $(\mathrm{n}, \mathrm{X} \backslash \mathrm{A})(\mathrm{n}, \mathrm{A})$ \\
\hline 95Am239 & $(\mathrm{n}, \mathrm{X} \backslash \mathrm{A})(\mathrm{n}, \mathrm{A})(\mathrm{n}, \mathrm{A})(\mathrm{n}, \mathrm{G})$ \\
\hline 97Bk248m1 & $(\mathrm{n}, \mathrm{X} \backslash \mathrm{A})(\mathrm{n}, \mathrm{A})(\mathrm{n}, \mathrm{N})(\mathrm{n}, \mathrm{G})$ \\
\hline 99Es250 & $(\mathrm{n}, \mathrm{X} \backslash \mathrm{P})(\mathrm{n}, \mathrm{X} \backslash \mathrm{A})(\mathrm{n}, \mathrm{NA})(\mathrm{n}, \mathrm{A})(\mathrm{n}, \mathrm{P})(\mathrm{n}, \mathrm{G})$ \\
\hline 99Es256m1 & $(\mathrm{n}, \mathrm{X} \backslash \mathrm{A})(\mathrm{n}, \mathrm{DA})(\mathrm{n}, \mathrm{NA})(\mathrm{n}, \mathrm{A})(\mathrm{n}, \mathrm{G})$ \\
\hline 99Es257 & $(\mathrm{n}, \mathrm{X} \backslash \mathrm{A})(\mathrm{n}, \mathrm{A})$ \\
\hline $100 \mathrm{Fm} 252$ & $(\mathrm{n}, \mathrm{X} \backslash \mathrm{A})(\mathrm{n}, 2 \mathrm{~A})(\mathrm{n}, \mathrm{NA})(\mathrm{n}, \mathrm{A})(\mathrm{n}, \mathrm{G})$ \\
\hline $100 \mathrm{Fm} 253$ & $(\mathrm{n}, \mathrm{X} \backslash \mathrm{A})(\mathrm{n}, 2 \mathrm{~A})(\mathrm{n}, \mathrm{NA})(\mathrm{n}, \mathrm{N} 3 \mathrm{HE} \mathrm{A})(\mathrm{n}, \mathrm{G})$ \\
\hline $100 \mathrm{Fm} 257$ & $(\mathrm{n}, \mathrm{X} \backslash \mathrm{P})(\mathrm{n}, \mathrm{X} \backslash \mathrm{A})(\mathrm{n}, \mathrm{NA})(\mathrm{n}, \mathrm{A})(\mathrm{n}, \mathrm{P})(\mathrm{n}, \mathrm{G})$ \\
\hline
\end{tabular}

